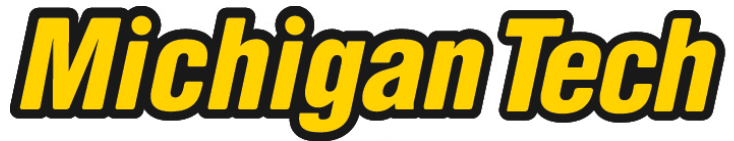 \\ Michigan Technological University Create the Future Digital Commons @ Michigan Tech
}

\section{Application of well log tomography to the Dundee and Rogers City Limestones, Michigan Basin, USA}

Mellisa A. Le M.

Michigan Technological University

Follow this and additional works at: https://digitalcommons.mtu.edu/etds

Part of the Geology Commons

Copyright 2004 Mellisa A. Le M.

\section{Recommended Citation}

Le, Mellisa A. M., "Application of well log tomography to the Dundee and Rogers City Limestones, Michigan Basin, USA", Master's Thesis, Michigan Technological University, 2004.

https://doi.org/10.37099/mtu.dc.etds/328

Follow this and additional works at: https://digitalcommons.mtu.edu/etds

Part of the Geology Commons 


\title{
APPLICATION OF WELL LOG TOMOGRAPHY TO THE DUNDEE AND ROGERS CITY LIMESTONES, MICHIGAN BASIN, USA
}

\author{
By \\ Mellisa A. Le
}

\begin{abstract}
A THESIS
Submitted in partial fulfillment of the requirements

for the degree of

MASTER OF SCIENCE

Geological Engineering

MICHIGAN TECHNOLOGICAL UNIVERSITY

2004
\end{abstract}


This thesis, "Application of Well Log Tomography to the Dundee and Rogers City Limestones, Michigan Basin, USA" is hereby approved in partial fulfillment of the requirements for the degree of MASTER OF SCIENCE in the field of Geological Engineering.

Department of Geological and Mining Engineering and Sciences

Signatures:

Thesis Advisor:

James R. Wood

Department Chair:

Wayne D. Pennington

Date: 


\begin{abstract}
The Michigan Basin is located in the upper Midwest region of the United States and is centered geographically over the Lower Peninsula of Michigan. It is filled primarily with Paleozoic carbonates and clastics, overlying Precambrian basement rocks and covered by Pleistocene glacial drift. In Michigan, more than 46,000 wells have been drilled in the basin, many producing significant quantities of oil and gas since the 1920s in addition to providing a wealth of data for subsurface visualization.

Well log tomography, formerly log-curve amplitude slicing, is a visualization method recently developed at Michigan Technological University to correlate subsurface data by utilizing the high vertical resolution of well log curves. The well log tomography method was first successfully applied to the Middle Devonian Traverse Group within the Michigan Basin using gamma ray log curves. The purpose of this study is to prepare a digital data set for the Middle Devonian Dundee and Rogers City Limestones, apply the well log tomography method to this data and from this application, interpret paleogeographic trends in the natural radioactivity. Both the Dundee and Rogers City intervals directly underlie the Traverse Group and combined are the most prolific reservoir within the Michigan Basin. Differences between this study and the Traverse Group include increased well control and "slicing" of a more uniform lithology.

Gamma ray log curves for the Dundee and Rogers City Limestones were obtained from 295 vertical wells distributed over the Lower Peninsula of Michigan, converted to Log ASCII Standard files, and input into the well log tomography program. The "slicing" contour results indicate that during the formation of the Dundee and Rogers City intervals, carbonates and evaporites with low natural radioactive signatures on gamma
\end{abstract}


ray logs were deposited. This contrasts the higher gamma ray amplitudes from siliciclastic deltas that cyclically entered the basin during Traverse Group deposition. Additionally, a subtle north-south, low natural radioactive trend in the center of the basin may correlate with previously published Dundee facies tracts. Prominent trends associated with the distribution of limestone and dolomite are not observed because the regional range of gamma ray values for both carbonates are equivalent in the Michigan Basin and additional log curves are needed to separate these lithologies. 


\section{Acknowledgements}

This research project was funded by the U.S. Department of Energy, contract \#DE-FC26-00BC15122 and PRF 39872-AC8 awarded to Dr. J. Wood. Neuralog Inc. provided scanning and digitizing software and LandMark Corp. provided the GeoGraphix software.

I thank my advisor, Dr. Wood, for providing me this research opportunity, for keeping me on track and for helping me edit my thesis. I also thank Dr. "Buddy" Wylie for serving on my committee, for providing literature search materials, for the many discussions and for helping me use GeoGraphix. I will ever be grateful for all of the time that he spent helping me every step of the way. I also acknowledge my other committee members, Dr. Gierke for always giving me guidance and wisdom and Dr. Harrison for providing invaluable input on the thesis and for traveling many miles to be at my defense.

I thank Carol Asiala, creator of the Slice 2 program, for helping me with MS ACCESS and for having patience with all of my requests. I am also grateful for the digitizing aid I received from Gerard Czarnecki and I thank Amie Ledgerwood for helping me with the graduate school paperwork.

I thank Doug Moore for the MUB trips, good meals, rocks (especially greenstones and datolite) and many years of great friendship. I thank Father Larry for spiritual guidance. I thank my family: Dad, Mom, Kim, Annah, Thai, Grandpa and Grandma for their love and for always being proud of me. Lastly, I thank my fiancé, Brian Mooren, for being my confidant and my strength. 


\section{Table of Contents}

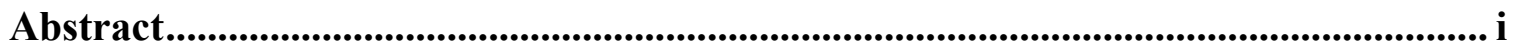

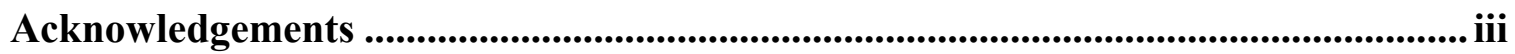

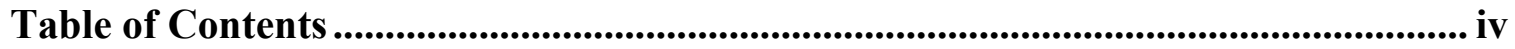

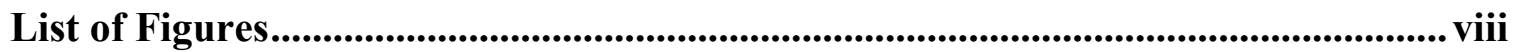

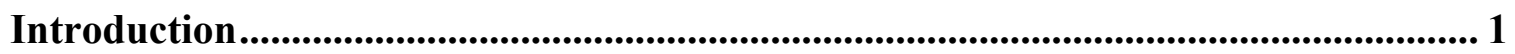

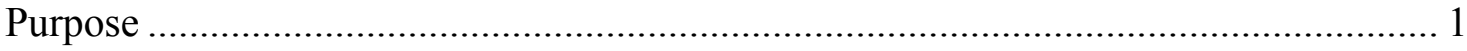

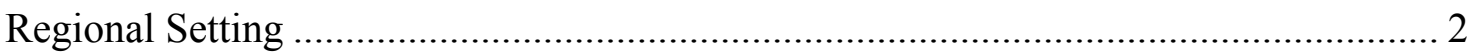

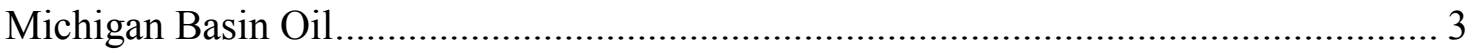

Literature Review ........................................................................................................ 4

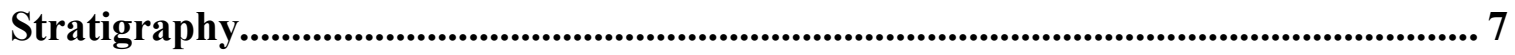

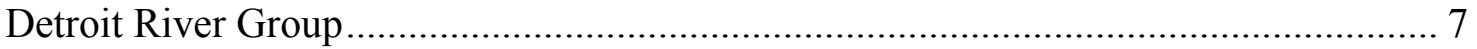

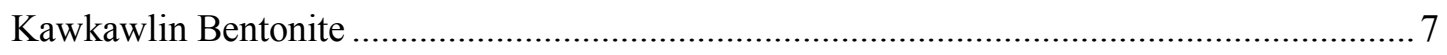

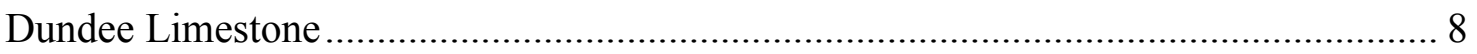

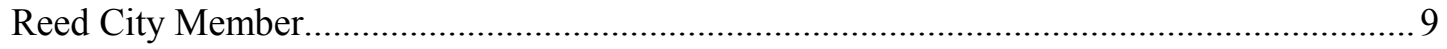

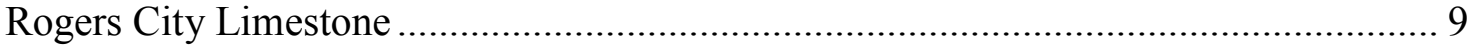

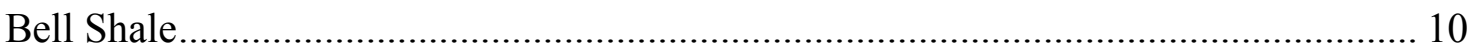

Well Log Tomography Introduction ................................................................................... 11

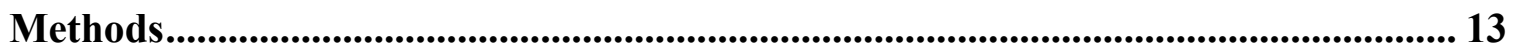

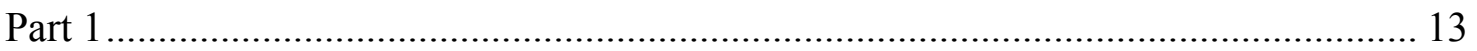

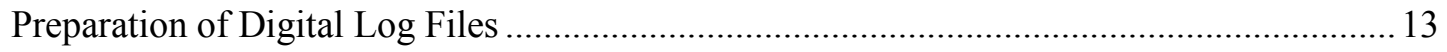

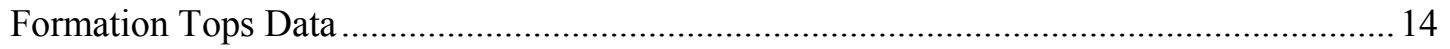

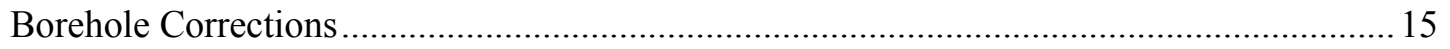

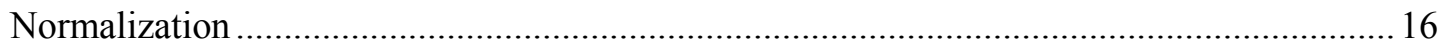




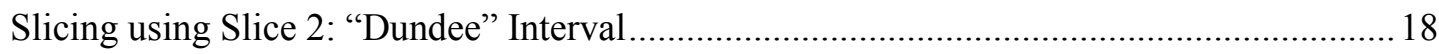

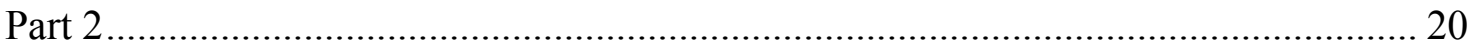

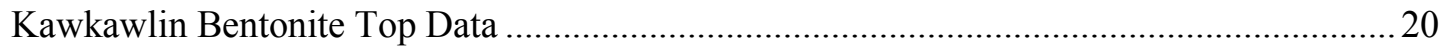

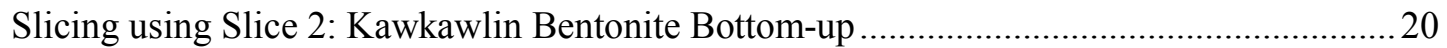

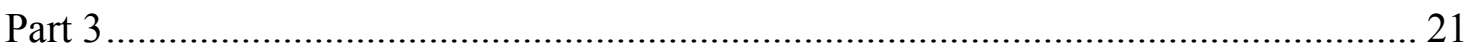

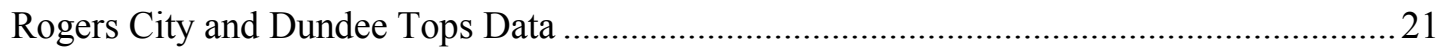

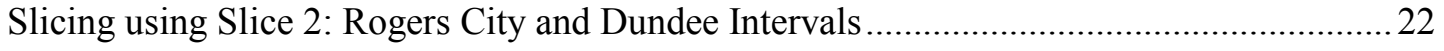

Depositional Model ........................................................................................................ 23

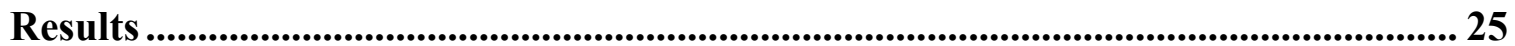

"Dundee" Limestone: Top-down Slice Images .................................................. 25

Kawkawlin Bentonite: Bottom-up Slice Images ................................................... 26

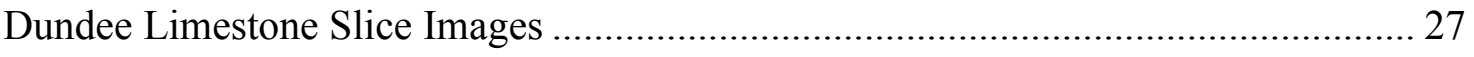

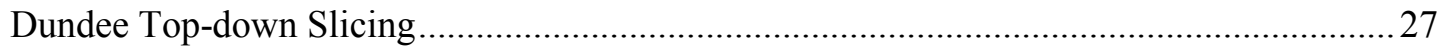

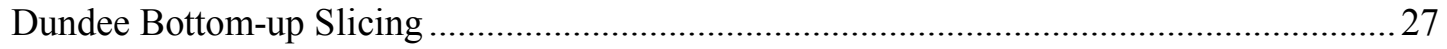

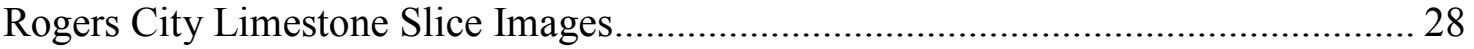

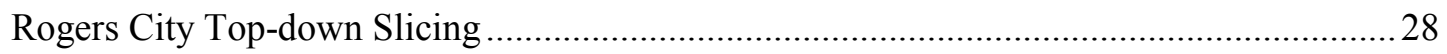

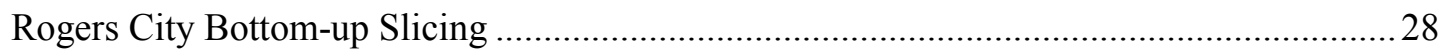

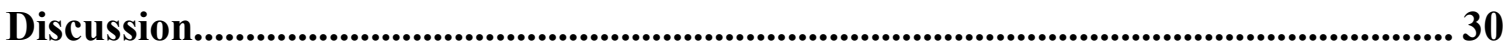

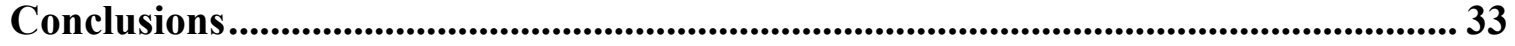

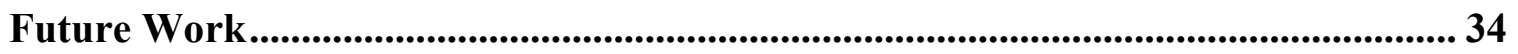

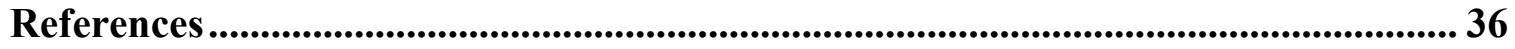

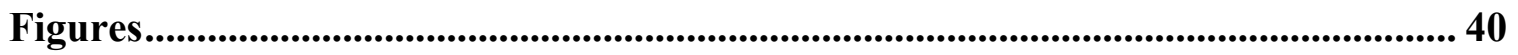

Appendix A: Digital Log Information............................................................................ A-1

Appendix B: Histograms ....................................................................................... B-1 
Appendix C: Surfer Gridding Report ................................................................. C-1

Appendix D: Surfer Color Files............................................................................. D-1 


\section{List of Figures}

Figure 1. Location of the Michigan Basin outlined in black. The dark purple region highlights the Devonian bedrock geology (from Wylie and Huntoon, 2003).

Figure 2. Stratigraphic column for the Michigan Basin, modified from the Michigan Department of Environmental Quality, Geological Survey Division and the Michigan Basin Geological Society (2000), accessed at $<$ http://www.deq.state.mi.us/documents/deq-gsd-info-geologyStratigraphic.pdf $>$ on Jan. 15, 2004.

Figure 3. Location map for 2003 Dundee-Rogers City producing wells (black dots) from the Michigan Department of Natural Resources (MDNR) production database. County names are also shown for reference within the paper.

Figure 4. (A) Stratigraphy diagram for the Dundee-Rogers City and surrounding Middle Devonian units from west to east across the central Lower Peninsula of Michigan (modified from Catacosinos et al., 1991). (B) Cross-sectional stratigraphy schematic from southwest toward the center of the basin, illustrating that the Bell Shale, Rogers City and Dundee intervals are all absent in portions of southwestern Michigan. Note that the vertical scale is exaggerated.

Figure 5. Outcrop and subcrop locations for the Detroit River Group and the combined DundeeRogers City ("Dundee") unit. A dotted line in the southwest region illustrates the absence of the Dundee Limestone due to erosion. Black closed circles represent wells used in the WLT slicing program and orange open circles locate the wells discarded before slicing. Crosssection lines are also shown for subsequent figures.

Figure 6. Example digital well log, from the Alber \#1-23 well, permit 40215 located in Mecosta County, Michigan. The gamma ray (GR) log curve is located on the left track of the well log with a color-filled amplitude. On the right track are the density (RHOB) log curve (red), neutron (blue) and photoelectric effect (green). The top picks are labeled on the depth scale in the center track. The Reed City is labeled but has no top pick because it is only a Member of the Dundee and is not present throughout the entire basin.

Figure 7. Illustration of the well log tomography method on the Dundee-Rogers City interval located between the Bell Shale (BS) and Detroit River Group (DRRV). Cross-section line, A-A', (Figure 5) includes four representative wells used to illustrate the slicing method. These wells from left to right, west to east across the Lower Peninsula of Michigan are: Mason County/ Carnagel Oil Associates \#3-30/ permit 32471; Osceola County/ Thompson \#1-27/ permit 39443; Gladwin County/ Dull \#3-6/ permit 35846; Arenac County/ Hagley \#1$21 /$ permit 34973 . The gamma ray is shown on the left track of the log and the lithology is shown on the right with the lithology legend located below the figures. (A) Example of topdown slicing. The common datum point is the top of the Dundee-Rogers city interval. Slices are shown as solid red lines approximately every $20 \mathrm{ft}$. The westernmost well with the thinnest Dundee interval has the fewest slices. (B) Example of bottom-up slicing. Opposite of (A) with the common datum point at the base of the Dundee-Rogers City interval. Slices are also shown as solid red lines approximately every $20 \mathrm{ft}$.

Figure 8. Gamma ray log curve of the Dundee and Rogers City interval for the Croton \#1-30 well, permit 41892 located in Newaygo County. The lithology as described by Gardner (1974) 
from core in a nearby well is shown to the right of the log curve and illustrates the gamma ray amplitudes for the different lithologies.

Figure 9. (A) Map showing where the Bell Shale-"Dundee" contact is easy (sharp contrast) and difficult (no contrast, absence of Bell Shale) to pick using the gamma ray log curve. The wells within the region between the solid and dotted red lines indicate a moderately difficult pick due to the thinning of the Bell Shale but a contrast between the "Dundee" and the overlying Traverse Group. (B) Map showing where the density log is present, identified by a sharp contrast between the "Dundee" and the first anhydrite within the Detroit River Group. In the southeast, the lithology changes and the "Dundee"-Detroit River anhydrite contact cannot be picked with confidence using only well log curves.

Figure 10. Cross-plot used to determine if a borehole correction was necessary. (A) Casing width (a proxy for borehole diameter) versus the average gamma ray value for the Dundee-Rogers City interval in 217 wells. (B) Casing width versus the standard deviation for the DundeeRogers City interval in 217 wells.

Figure 11. Contour maps illustrating the distribution of (A) casing diameter size (in) and (B) standard deviation (APIU) for the Dundee-Rogers City interval in 217 wells.

Figure 12. Frequency histogram of the average gamma ray value for (A) 302 sliced wells and (B) 295 sliced wells after those wells having a standard deviation greater than two were excluded. The bars represent the number of wells for each average gamma ray value range. The dotted curve illustrates the smoothed distribution.

Figure 13. Screen capture of the Slice 2 Files and Parameters form. With this form, the user identifies slicing parameters such as the locations of all the necessary databases, outline of the sliced region, the curve used for slicing, slicing method (either top-down or bottom-up), the LAS files needed, surfer color contour scale, contour interval and minimum and maximum values.

Figure 14. Structure contour map of the Kawkawlin Bentonite pick. The dotted line traces the truncation of the ash bed as defined by Baltrusaitis (1974). The black dots represent the 172 wells used in the study that had a bentonite pick on the gamma ray log curve.

Figure 15. Top of the Rogers City structure contour map. Contour interval is $200 \mathrm{ft}$. The dotted line (from Cohee and Underwood, 1945) traces the zero-outline of the Rogers City Limestone.

Figure 16. Top of the Dundee Limestone structure contour map. Contour interval is 200 feet. The dotted line (from Cohee and Underwood, 1945) in the southwestern counties indicates the edge of the subsurface Dundee Limestone.

Figure 17. Isopach of the Rogers City Limestone. Contour interval is $6 \mathrm{ft}$. Zero-outline (from Cohee and Underwood, 1945) of the Rogers City is shown as a black dotted line.

Figure 18. Isopach of the Dundee Limestone. Contour interval is $20 \mathrm{ft}$. The dotted line (from Cohee and Underwood, 1945) in the southwestern counties indicates the edge of the subsurface Dundee Limestone. 
Figure 19. SW to NE cross-section from Berrien County to Saginaw Bay shown as B-B' on Figure 5. The gamma ray log curve (0-40 apiu) is shown on the right track and has a colorcoded amplitude. The center track illustrates lithology data from mud logs in the Aangstrom Precision Corp database. The right track illustrates the red bulk density curve $(2-3 \mathrm{~g} / \mathrm{cc})$, the green photoelectric effect curve (0-6 barnes/e-) and blue neutron porosity curves (NEUT: 01000 napi; SNP: ${ }^{-15}-45 \%$; NPHI: $30-10 \%$ ).

Figure 20. (A) Gardner's (1974) Dundee depositional environment model. (B) Taylor's (2001) interpretation of the Dundee depositional environment superimposed onto the Gardner model to illustrate their similarity.

Figure 21. Diagrams illustrating the sliced intervals (shaded) and direction of slicing (arrow) presented in the results section. (A) Top-down slicing of the "Dundee" Limestone (B) topdown slicing of the Rogers City Limestone, (C) top-down slicing of the Dundee Limestone, (D) bottom-up slicing of the Rogers City Limestone, (E) bottom-up slicing of the Dundee Limestone and (F) bottom-up slicing from the Kawkawlin Bentonite layer.

Figure 22. Representative top-down slices for the "Dundee" interval. Slice numbers correspond to the depth (ft) beneath the Bell Shale-"Dundee contact. The contour interval is 15 APIU and the white dots represent the wells used for contouring.

Figure 23. Representative bottom-up slices from the Kawkawlin Bentonite layer toward the top of the Dundee Limestone. Slice numbers correspond to the depth (ft) above this bentonite. The contour interval is 3 APIU and the white dots represent the wells used for contouring. Note that the black color within the contoured area for Slices 1 and 3 is a product of the gridding algorithm and lies within the 27-30 APIU range.

Figure 24. Representative top-down slices for the Dundee Limestone. Slice numbers correspond to the depth (ft) beneath the Dundee Limestone top pick. The contour interval is 3 APIU and the white dots represent the wells used for contouring. Note that the black color within the contoured area for Slices 1 and 3 is a product of the gridding algorithm and lies within the 27-30 APIU range.

Figure 25. Representative bottom-up slices for the Dundee Limestone. Slice numbers correspond to the depth (ft) above the Detroit River Group top pick. The contour interval is 3 APIU and the white dots represent the wells used for contouring.

Figure 26. Representative top-down slices for the Rogers City Limestone. Slice numbers correspond to the depth (ft) beneath the Bell Shale-Rogers City Limestone contact. The contour interval is 3 APIU and the white dots represent the wells used for contouring. Note that the black color within the contoured area for Slices 2 and 3 is a product of the gridding algorithm and lies within the 27-30 APIU range.

Figure 27. Representative bottom-up slices for the Rogers City Limestone. Slice numbers correspond to the depth (ft) above the Rogers City-Dundee contact. The contour interval is 3 APIU and the white dots represent the wells used for contouring.

Figure 28. Twelve representative proportional slice images of the Traverse Group. The color contour scale is as follows: blue- less than 40 APIU, green and yellow- 40 to 80 APIU, brown and red- 80 to 150 APIU. The blue contours infer carbonate lithology, green-yellow 
contours infer mixed carbonate and shale (e.g. argillaceous limestone), and the brown-red contours infer shale or claystone (taken from Wylie, 2002).

Figure 29. Comparison of the Bell Shale using the WLT and LCAS methods. (A) WLT slice image for $5 \mathrm{ft}$ above the base of the Bell Shale. (B) LCAS proportional slice image at the base of the Bell Shale (taken from Wylie, 2002). Note that the color contour scale refers only to the WLT slice (A).

Figure 30. (A) Slice 19 from the top-down Dundee Limestone results. (B) Taylor's (2001) depositional model for the upper Dundee superimposed onto slice 19 illustrating the similarity between the shelf trend in Taylor's model and the low gamma ray trend from the slicing results. 


\section{Introduction}

\section{Purpose}

Well log tomography (WLT), formerly termed log-curve amplitude slicing (LCAS), is a subsurface visualization technique that was developed at Michigan Technological University (MTU) by A. S. Wylie (2002). The technique is analogous to computed axial tomography or a CAT scan in the medical field that creates x-ray crosssectional images or "slices" of a body and then combines them through the use of a computer to produce a three-dimensional image (Goldman, 2004). Similarly, WLT generates slices of the subsurface strata, but instead of constructing a three-dimensional depiction of the data, the slices are placed into a visualization program to be viewed in sequential order as a "movie."

The importance of WLT is that the technique improves subsurface imagery by utilizing the high vertical resolution of well log data. Wylie (2002) and Wylie and Huntoon (2003) successfully applied WLT regionally to the Middle Devonian Traverse Group of the Michigan Basin. Their results revealed the presence of previously unknown siliciclastic deltas feeding into the Michigan Basin from the east-southeast and northeast, and aided in the reconstruction of a relative water depth curve. The purpose of this study is to apply the same slicing technique to the Middle Devonian Dundee and Rogers City Limestones within the Michigan Basin, analyze well log amplitude patterns and compare these results with those from the Traverse Group. There were two primary reasons for choosing the Dundee and Rogers City, including proximity to the Traverse Group as well as the economic importance of the formations to Michigan oil production. 
Background information for the study area is given below. This is followed by a literature review of past studies performed on the Dundee and Rogers City Limestones and a detailed description of their stratigraphy. Then the WLT method is described as well as a depositional model for the Dundee interval. The WLT results, discussions of slicing correlations, and conclusions are then presented. Lastly, suggestions for future work are included to further improve the delineation of new trends when slicing subsurface data.

\section{Regional Setting}

The intracratonic Michigan Basin is centered over the Lower Peninsula of Michigan and encompasses a circular surface area of $80,000 \mathrm{mi}^{2}$ if extended into portions of the Upper Peninsula, Ontario, Ohio, Indiana, Illinois and Wisconsin (Catacosinos et al., 1991). Figure 1 shows the outline of the Michigan Basin, bordering arches, and major anticline trends that follow the dominant northwest-southeast structural grain. Subsidence within the Michigan Basin occurred from Cambrian to Carboniferous time but was not laterally or temporally uniform (Fisher et al., 1988). Many mechanisms have been proposed to explain the irregular subsidence history of the basin including thermal contraction, metamorphic phase changes, lithospheric stretching, free thermal convection and intraplate stress mechanisms, but the origin remains uncertain (Howell and van der Pluijm, 1999).

The inwardly dipping sediments that fill the basin are sandwiched between

Precambrian basement rocks and recent Pleistocene glacial deposits (Figure 2). This fill is comprised of Paleozoic (Cambrian to Pennsylvanian) carbonates, evaporites and 
clastics but the basin interior also contains younger, terrestrial Jurassic red beds. As shown in Figure 1, the Paleozoic and Jurassic bedrock geology form a concentric pattern, with progressively older rocks subcropping toward the perimeter. These rocks approach a thickness of $16,000 \mathrm{ft}$ toward the basin depocenter but rarely outcrop at the surface because of the thick glacial drift, in some areas totaling 1,200 $\mathrm{ft}$. Initially, these glacial deposits masked study of the underlying geology until oil exploration increased the quantity of and accessibility to subsurface data (Catacosinos et al., 1991).

\section{Michigan Basin Oil}

The earliest discovery of oil within the Michigan Basin occurred in 1858 at Oil Springs, Ontario (Dolton, 1995). Oil production within the state of Michigan did not occur until 1886 at Port Huron field in St. Clair County. Then in 1925, a large pool within Saginaw County, Michigan initiated heightened oil exploration and production within the basin (Catacosinos et al., 1991). Since this time more than 46,000 wells have been drilled within the Michigan Basin, cumulatively producing over 1.2 billion barrels of crude oil and condensate (Petroleum Technology Transfer Council- PTTC, 2004). Distribution of current Dundee-Rogers City production wells is shown in Figure 3. The Dundee-Rogers City unit accounts for approximately one-third (over 351 million barrels) of the total oil production within the basin. This figure surpasses all other cumulative totals for a single formation through 1986 but is closely trailed by production from the Salina-Niagaran formations, having produced 325 million barrels through 1986 (PTTC, 2004). 


\section{Literature Review}

A description of the Middle Devonian "Dundee Limestone" was first published in 1895 by Alfred C. Lane based on the fieldwork of Charles E. Wright. In Lane's account, rock samples from deep borings were correlated to outcrops in various locations including Monroe County, Mason Creek quarries (Monroe County), and north of Mackinaw City. Lane identified the upper limit of the Dundee Limestone as "separating a great series of bluish grey or black, largely argillaceous rocks [Bell Shale], from a great series of buff, yellow or almost white, largely calcareous ones." Acid tests were then used to locate the lower limit, separating the Dundee Limestone from the underlying dolomite [Detroit River Group] (Lane, 1895).

The economic importance of the Dundee became apparent after oil production began in 1927 (Gardner, 1974), and this initiated subsequent studies on the formation. Subjects covered by these studies include the nature of the Dundee contacts (Newcombe, 1930); studies of the Dundee within individual oil fields, regions or counties (Newcombe, 1932; Addison, 1940; Landes, 1944; Landes, 1948; Kellum, 1958; Bush, 1983; Little, 1986; Curran and Hurley, 1992); investigations of fossils within the Dundee unit (Bassett, 1935; Ehlers and Radabaugh, 1938; Radabaugh, 1942;); mapping the Dundee distribution (Radabaugh, 1942; Cohee and Underwood, 1945; Lilienthal, 1978), studying dolomitization (Tinklepaugh, 1957; Bloomer, 1969); facies (Montgomery, 1986); stratigraphic correlations (Sanford, 1967); structure (Beckman and Whitten, 1969); stratigraphy (Gardner, 1974); as well as broad overviews of the Dundee in the context of the Michigan Basin (Fisher et al., 1988; Catacosinos et al., 1991). 
A fundamental outcome of these studies was the revisions made to Lane's original stratigraphic nomenclature for the Middle Devonian Dundee unit. The first modification was the separation of the Dundee into two formations by Ehlers and Radabaugh (1938) based on a faunal distinction between the lower and upper Dundee in Presque Isle County. The upper formation, directly below the Bell Shale of the Traverse Group, was termed the "Rogers City limestone." Species of fossils in this unit closely correlated with the "Winnipegosan dolomite" in Manitoba, Canada and were different than those fossils of the underlying formation (Radabaugh, 1942). This lower formation was termed the "Dundee limestone" (Ehlers and Radabaugh, 1938). Cohee and Underwood (1945) applied this division on a regional scale via mapping the thickness of both the Rogers City and Dundee over the Michigan Basin primarily using drill cuttings. Not all workers, however, were able to distinguish the Rogers City from the Dundee and informally used the term "Dundee" to describe both limestone units (Kellum, 1958; Bloomer, 1969; Lilienthal, 1978; Little, 1986; Fisher et al., 1988; Catacosinos et al., 1991).

In response to the lack of continuity regarding Dundee terminology, Gardner (1974) proposed another revision. He used the term "Dundee Formation" to describe the rocks between the Bell Shale and the Detroit River Group. Within this formation, Gardner identified two members, the Rogers City and the Reed City. In 1986, Montgomery noted that the stratigraphic nomenclature remained "disjointed" and attributed the inconsistency to basing the formation and member names on either stratigraphic position, facies, diagenetic lithology or geographic position. In addition to these four factors, the writer notes that nomenclature is also dependent on whether the study is based on well cuttings, driller's logs, cores, fauna, mechanical log curves or a 
combination of these resources. In this paper, the term Rogers City Limestone and Dundee Limestone are used to describe separate formations (Figure 4) in concordance with the American Association of Petroleum Geologists (AAPG) Midwestern basin and arches correlation chart (Shaver, 1984). The Reed City will be considered a Member within the Dundee Limestone. A more detailed account of the literature with respect to the stratigraphy of the Middle Devonian units (Figure 4) is given in the following section. 


\section{Stratigraphy}

\section{Detroit River Group}

The upper Detroit River Group directly underlies the Dundee Limestone (Figures 2 and 4) and is composed of a cyclic series of shallow-water dolomite, limestone, sandstone, anhydrite and salt, excluding shale (Lilienthal, 1978). In the Lower Peninsula, the Detroit River Group is everywhere present except in the extreme northern and southeastern regions (Figure 5). The contact between the Detroit River Group and the Dundee Limestone is irregularly marked by an erosional unconformity and is difficult to distinguish due to lithology similarities (Landes, 1951; Baltrusaitis, 1974). Lilienthal (1978) stated that this pick is often placed a few feet below the top of the Detroit River Group at the first anhydrite or is based upon other lithology characteristics when this anhydrite is not present. Gardner (1974) was one of the workers that used the anhydrite to define the contact except in the absence of anhydrite toward the southeast region of the basin, where he instead used a thin potassium-bentonite ash bed as described below. In this paper, the base of the Dundee is also picked at the first anhydrite within the Detroit River Group.

\section{Kawkawlin Bentonite}

The uppermost unit of the Detroit River Group contains a volcanic bentonite ash bed (Figure 4). Baltrusaitis (1974) proposed the name Kawkawlin Bentonite for this chronostratigraphic surface after the type well located in the Kawkawlin oil field, Bay County, Michigan. This bentonite can be regionally correlated to the Tioga Bentonite of southwestern Ontario (Baltrusaitis, 1974) and northern Indiana (Doheny et al., 1975). As shown in Figure 6, the ash-fall bed appears as a "spike" on gamma ray logs. Baltrusaitis 
(1974) also identified a second ash bed above the Kawkawlin Bentonite, possessing a similar gamma ray signature but having a slightly different composition. This additional bentonite spike is not present in Figure 6 but can be observed in other gamma ray log curves throughout the basin.

\section{Dundee Limestone}

The Dundee Limestone is present throughout most of the Lower Peninsula. The formation outcrops in the northernmost counties, subcrops beneath the glacial drift in southeastern Michigan and is absent due to erosion in the southwestern tip of the Lower Peninsula (Figure 5). The Dundee Limestone is described as a "buff-to-brownish gray, finely to coarsely crystalline limestone" (Lilienthal, 1978; Catacosinos et al., 1991). In the westernmost regions of the basin, the Dundee is typically dolomite whereas both limestone and dolomite are present in the basin center. Primary and secondary porosity zones within the limestone and dolomite play a significant role in Dundee oil and gas production (Lilienthal, 1978).

The contact between the Dundee Limestone and the overlying Rogers City was originally described as conformable (Ehlers and Radabaugh, 1938; Tinklepaugh, 1957). Radabaugh (1942) made a detailed map of the northern Rogers City outcrop and showed that the limestone thinned from north to south across the basin but could not confirm if the absence of the Rogers City was due to erosion or non-deposition. A more recent publication by Curran and Hurley (1992), in their study of the West Branch oil field in Ogemaw County, stated that this contact is a disconformity, distinguished by a bored hardground due to a period of non-deposition that pyritized the top of the Dundee. 


\section{Reed City Member}

The Reed City is a Member within the Dundee Limestone and is only present in the westernmost Michigan Basin (Figure 4A) and consequently could not be used as a regionally correlative surface for slicing. Gardner (1974) described the Reed City as a porosity zone containing both laminated anhydrite and massive dolomite deposited during a brief period of Dundee sea regression. This porosity zone is important because it produces both oil and gas (Lilienthal, 1978) and helps define the Dundee depositional environment.

\section{Rogers City Limestone}

The initial separation of the Rogers City Limestone from the Dundee Limestone was based on quarry exposures at Rogers City in Presque Isle County (Ehlers and Radabaugh, 1938). Shortly after this initial publication, Addison (1940) described the Rogers City based on subsurface lithology data at Buckeye oil field in Gladwin County. Addison noted that the Rogers City was darker and denser than the Dundee. Similarly, Landes (1944) described the Rogers City to be "waxy" and darker than the Dundee at Porter oil field in Midland County. Within this oil field, distinguishing between the Rogers City and the Dundee had economic importance as oil was produced directly beneath the Dundee-Rogers City contact (Landes, 1944).

The contact between the Rogers City and the overlying Bell Shale is readily apparent on gamma ray log curves (Figure 6). This contact was originally described as a disconformity (Ehlers and Radabaugh, 1938) based on local removal of 46 feet of Rogers City at Michigan Limestone and Chemical Company quarry in Presque Isle County. 
Other workers such as Radabaugh (1942) and Ehlers and Kesling (1970) confirmed this disconformity, but relied upon data at the margin of the basin. Addison (1940) stated that the thickness of the Rogers City did not vary over an anticlinal structure in the Buckeye field of central Michigan. From this observation he concluded that the contact between the Bell Shale and the Rogers City appeared to be conformable. Gardner (1974) concluded that an unconformable relationship exists between the Rogers City and the Bell Shale at the basin margin but is conformable in the deeper, central region of the basin.

\section{Bell Shale}

The Bell Shale is the basal member of the Traverse Group and directly overlies the Rogers City Limestone. When the Rogers City is not present, in areas such as western and southern Michigan, the Bell Shale overlies the Dundee Limestone. In 1901, Amadeus W. Grabau first used the term "Bell Shale" when describing bluish colored shale in abandoned clay pits in southeastern Presque Isle County (Ehlers and Kesling, 1970). The Bell Shale Formation studied at quarries and from cores in Presque Isle and Alpena Counties, was deposited on an erosional surface at the top of the Rogers City Limestone.

The lower section of the Bell Shale contains crinoid fragments indicating turbulent water conditions whereas fossils in the upper section depict a calmer, deepwater environment (Ehlers and Kesling, 1970). Bloomer (1969) described a small calcareous unit (lag deposit) at the base of the Bell Shale in the southwest region of the basin and traced it moving upward through the Bell Shale toward the northeast. He interpreted this trend to be the product of a northern sea transgressing across the basin. 


\section{Well Log Tomography Introduction}

Well logs are records of subsurface drilling and include driller's logs, sample logs, mud logs and wireline logs. Driller's logs contain observations involving rocks and fluids that emerge during drilling. Sample logs are physical pieces of subsurface rock taken from the borehole and consist of either cuttings or cores. Mud logs describe the lithology of cuttings and are recorded at the well site by a geologist. Wireline logs record various properties in the subsurface and include electric, radioactivity or acoustic logs (Van Dyke, 1997).

The WLT method employs wireline logs. Wireline tools can record data at every foot within a borehole. However, as described by Wylie (2002), common practice is to average wireline log curve amplitudes when correlating well data. Consequently, Wylie's primary objective for creating the slicing program (WLT) was to analyze well log curves without compromising their vertical resolution (Wylie, 2002; Wylie and Huntoon, 2003). A schematic of the slicing technique is shown in Figure 7 for the combined DundeeRogers City Limestones. By creating a slice at every foot, the full vertical resolution contained within the log curve data is preserved in each well. The log curve amplitude for each well along a slice are then plotted and contoured in plan-view.

This study uses the gamma ray wireline log that records the natural radioactivity of a formation due to the presence of three radioisotopes, uranium $\left({ }^{238} \mathrm{U}\right)$, potassium $\left({ }^{40} \mathrm{~K}\right)$ and thorium $\left({ }^{232} \mathrm{Th}\right)$. As the isotopes of $\mathrm{U}, \mathrm{K}$ and Th decay, they emit short bursts of electromagnetic energy that can be measured by a gamma ray sensor. The American Petroleum Institute unit (APIU) is used as a measurement for gamma ray logs and is based on an artificial formation located in Houston, containing known values of $\mathrm{U}, \mathrm{K}$ and 
Th. A basic gamma ray log records the combined energies from $U, K$ and $T h$ whereas a spectral gamma ray log separates the signal into its three components. Basic gamma ray logs were only available for this study with the exception of the Prevost et al. \#1-11 well, permit 37770 in Bay County that had both a spectral and basic gamma ray log. Values from the spectral gamma ray log were too low to detect the source components using the Schlumberger CP-19 mineral identification chart (Schlumberger, 1986) and consequently will not be further discussed.

Gamma ray logs are useful for lithology studies because different types of sedimentary rocks exhibit a general range of gamma ray responses. Dewan (1983) stated that generally, pure limestone and anhydrite measure 15-20 APIU, dolomite and sandstones range between 20-30 APIU, and shales and volcanic ash (potassiumbentonite) measure high, on average 100 APIU. The Dundee-Rogers City gamma ray log curve for the Croton \#1-30 well, permit 41892 located in Newaygo County, is shown in Figure 8. The lithology from a core analysis by Gardner (1974) on a nearby well is also shown. In this well, anhydrite primarily ranges from 10-14 APIU, limestone averages 16 APIU and dolomite covers a broad range, between 10-50 APIU. The Bell Shale, located at the top of the figure, continues off-scale and averages approximately 120 APIU. 


\section{Methods}

\section{Part 1}

\section{Preparation of Digital Log Files}

The initial step in the preparation for performing WLT is to gather all the Log ASCII Standard (LAS) files within the area of interest, in this case, the Lower Peninsula of Michigan. These files were obtained digitally from commercial entities such as Maness Petroleum Corporation (Mt. Pleasant, Michigan) or were digitized in-house at MTU from paper logs. Over 900 digital well logs within the Lower Peninsula were reviewed from the Spatial Subsurface Visualization Laboratory database at MTU (Figure 5) and are listed in Appendix A.

The 295 final wells used for slicing were selected based upon two primary criteria. Most importantly, the wells had to contain a gamma ray curve throughout the entire Dundee and Rogers City interval. Incomplete or missing gamma ray curves accounted for twenty percent of those wells needing to be discarded. Secondly, groupings of wells within close proximity to one another were eliminated in order to obtain a uniform distribution over the basin. For example, after reviewing each well from an oil field or cluster within a county, only one or two representative wells were chosen instead of keeping every well that met the first criterion. This eliminated seventy-five percent of the LAS files. The remaining five percent of excluded LAS files were removed based on duplicate or triplicate files, deviated well, digitizing errors, outliers, or wells that appeared questionable to the writer. 


\section{Formation Tops Data}

The WLT technique slices log curve data between two correlative surfaces. Wylie and Huntoon (2003) stated that if these bounding surfaces can be defined as unconformities, sequence boundaries, parasequence boundaries, flooding surfaces, condensed sections or ash beds, then the slicing image results would be chronostratigraphically significant. An example of a chronostratigraphic surface would be the images that a satellite captures of the modern depositional surface.

Originally, the Dundee and Rogers City Limestones were not separated in this study because the location of their contact, based on previous publications, could not be identified with a high level of certainty using gamma ray logs. The top of the combined "Dundee" limestone was picked at the inflection point on the gamma ray log curve between the Bell Shale and the "Dundee" for every well (Figure 5). The inflection point was chosen as the contact because the complete change from shale to limestone on the logs was typically within the 3-4 $\mathrm{ft}$ vertical resolution range for the gamma ray data (Dewan, 1983). In general, the top of the "Dundee" was easier to identify in the center of the basin than in the southwest where the Bell Shale unit pinches or laps out (Figure 9A). Most of these picks were equivalent to the top values within the Department of Natural Resources (DNR) database.

The base of the "Dundee" was defined at the first anhydrite within the Detroit River Group. This pick was most consistent when the density log curve was available (Figure 5) and became more difficult in the southeastern part of the basin where log signatures for both units become exceedingly similar (Figure 9B). These top picks were fairly consistent with the DNR database. 
The top boundary of the "Dundee" is marked by an abrupt lithology change as well as an unconformity at the basin margins (Gardner, 1974). This correlative surface may be chronostratigraphically significant although Bloomer (1969) stated that, "the Dundee [including Rogers City] is not time equivalent" due to varying rates of deposition, such that increased distance from this surface would decrease the time significance of a given slice. Similarly, slices from the base of the "Dundee" only illustrate approximate time surfaces.

\section{Borehole Corrections}

Borehole effects are important to note in this study as they can affect the gamma ray response. Conditions for calibration of the gamma ray tool are defined by Dewan (1983) to include a hole diameter of 8-in, 10-1b drilling mud, and an eccentered logging tool with a $35 / 8$-in diameter. A dampened gamma ray response can be attributed to an increase in either the hole diameter or mud weight, or with the use of a centralized logging tool. Conversely, a smaller hole would shift the log curve toward higher gamma ray values (Dewan, 1983).

Charts such as the Schlumberger Por-7, provide correction factors that account for borehole effects using the hole diameter, mud weight and tool position (Schlumberger, 1986). Although the mud weight was typically recorded in the LAS files, neither the hole diameter or tool position were available in the LAS files or on paper logs of the wireline data. Consequently, a typical borehole correction could not be performed and is noted as a source of error in the data set.

Casing sizes, ranging from 4 1/2-in to 13 5/8-in, for 217 wells within the "Dundee" interval were available. By observing the gamma ray values for individual 
wells within the basin, there appeared to be no direct correlation between the casing size and the gamma ray amplitude. The casing sizes were then used as a proxy for borehole diameter and plotted against the gamma ray response for each well to observe possible relationships that could aid in applying a borehole correction. Figure 10 illustrates two cross-plots used to determine the necessity for a borehole correction. The figure includes (A) the average gamma ray value for the "Dundee" interval in each well plotted as a function of casing diameter and (B) standard deviation of the gamma ray values for the "Dundee" interval in each well plotted as a function of casing diameter. From these graphs, there is no apparent relationship between the casing size and the gamma ray values. Figure 11 highlights a trend between the distribution of low casing sizes and the standard deviation of the gamma ray values for each well. The cause of this relationship in the center of the basin, but not consistently over the entire basin, is unknown.

\section{Normalization}

Neinast and Knox (1974) and Hunt et al. (1996) stated that more than half of wells studied need to be normalized. Normalization is a correction applied to erroneous well $\log$ data to ensure that there is consistency between wells regarding the amplitude of the log curve response. The WLT technique examines amplitude changes rather than absolute amplitude values, but normalization was investigated because different types of errors can alter the amplitude change. "The basic sources of error are tool malfunction, incorrect tool design, inconsistent shop and field calibration, and operator error" (Neinast and Knox, 1974). In addition to these sources, Shier (1997) showed significant varying gamma ray responses based on a combination of logging contractors, drilling medium, and tool vintages. Hammack and Fertl (1974) described subsurface conditions that cause 
increased gamma ray amplitudes such as previously perforated intervals with salt present from old drilling fluid, fluid movement behind casing, and the presence of radioactive sandstones and carbonates. Hammack and Fertl also stated that "interpretation of gamma ray logs is straightforward if correctly calibrated and proper time constant and logging speed are used," although these log constraints are typically unknown for well logs within the Michigan Basin.

The normalization process includes defining a standard curve signature from either one well or a combination of representative wells. This "standard" can be based on a unit of sufficient lateral extent such as a shale layer, a low porosity carbonate or thick sandstone with low porosity. Each well used in the study is then normalized with the standard (Hunt et al., 1996). In this study, a standard formation either above or below the Dundee-Rogers City interval was difficult to identify because of lithology changes across the basin and incomplete digital gamma ray log curves. The Dundee-Rogers City interval was then analyzed to determine if it had a unique log curve signature that could be used as the standard to correct erroneous log amplitudes. This analysis consisted of creating frequency histograms of the gamma ray values within the Dundee-Rogers City interval for individual wells throughout the basin. Appendix B shows 18 histograms to illustrate the internal complexity of the Dundee-Rogers City interval. Consequently, normalization using one standard for the entire basin could not be performed because the correction was beyond the scope of this study and is noted as a source of error.

As a broad normalization for the 302 wells that were preliminarily sliced, a composite frequency histogram was constructed using the average gamma ray value for the Dundee-Rogers City interval in each well (Figure 12A). Of the 302 wells, all but 
seven wells fell within two standard deviations that equal about 95 percent of the data. Four wells were within the third standard deviation (99.7 percent of data) and three wells were far beyond the mean value. All seven wells were further analyzed and excluded from the final slicing (Figure 12B).

\section{Slicing using Slice 2: "Dundee" Interval}

Slice 2 is a Visual Basic computer program created at MTU by C. Asiala. This program is a modified version of the LogMovie program, also created by Asiala, which was used to slice the Traverse Group (Wylie, 2002; Wylie and Huntoon, 2003). The major difference between the original LogMovie and the Slice 2 program is that Slice 2 uses the Golden Software Surfer program to create contour maps of the log data whereas LogMovie used Production Analyst.

There are four forms and one module that comprise the Slice 2 program. The forms include Files and Parameters, Testing Options, LAS Database and Analysis. The Files and Parameters form (Figure 13) requires the user to define various aspects of the slicing components including the location of the LAS files, basemap parameters, color scale and contour interval, the log curve to be sliced and the direction of slicing (bottomup or top-down). The Testing Options form allows the user to complete the slicing in separate steps (create test files, slice files, surfer plots or a surfer poster). The LAS Database form retrieves the gamma ray values from the LAS files and inputs them into an Access database. The Analysis Form relies on this Access database to create a text file, where separate permit numbers define each row, and every column contains the gamma ray value for one slice. This form also alerts the user to any errors before the slicing 
images are created. The Mod1 module contains Surfer script commands for gridding the data and generating the slicing contour maps.

The parameters used for slicing the "Dundee" interval include top-down slicing, natural neighbor gridding algorithm (Appendix C), and varying contour intervals (3, 6, 12 and 15 APIU) and color scales. Confidence in the top pick for the "Dundee" surface justified performing the top-down method. The gridding algorithm was chosen such that the contouring would not extend beyond the well control because the "Dundee" thickness varies considerably throughout the basin $(0-400+\mathrm{ft})$. The first slicing trials used higher contour intervals (12 and 15 APIU) and a color scale similar to the Traverse Group study (blues: <40 APIU, green-yellow: 40-80, brown-red: 80-150) (Appendix D). The contour interval was reduced in subsequent slicing to enhance the trends in the data. The smallest contour interval used, 3 APIU, provided the best resolution because of the narrow "Dundee" gamma ray range (3-30 APIU). This interval is equal to the absolute magnitude deviation for clean carbonates, $\pm 2-4$ APIU (Dewan, 1983), but was still used to observe general trends. The contour color scale, for a three-foot contour interval using ten colors over a 0-30 APIU range, was repeatedly adjusted to better highlight trends within the data. The final color scale chosen incorporates varying shades of blue as well as green for the uppermost limits. These colors are comparable to the Traverse Group blue shades (<40 APIU) (Appendix D). 


\section{Part 2}

\section{Kawkawlin Bentonite Top Data}

To expand upon the initial WLT results, bottom-up slicing was performed using the Kawkawlin Bentonite as a chronostratigraphic surface. The ash bed is positioned below the base of the Dundee Limestone and slicing from this surface initially generates contour images for the uppermost section of the Detroit River Group before ascending into the Dundee. The Kawkawlin Bentonite was generally easy to identify using the gamma ray log and was picked at the peak (highest APIU) of the bentonite spike because the layer is thinner than the three-foot vertical resolution of the gamma ray log curve (Dewan, 1983).

From the 295 logs used in this study, 172 had an evident bentonite pick. The remaining wells either showed no spike, from the inability of the gamma ray log to consistently resolve the thin ash bed (Baltrusaitis, 1974); or contained more than one spike, making the Kawkawlin Bentonite indistinguishable from similar high gamma ray values. A structure contour map for the 172 wells containing the Kawkawlin Bentonite is shown in Figure 14 and illustrates the difficulty in identifying the Kawkawlin Bentonite in the northern part of the basin.

\section{Slicing using Slice 2: Kawkawlin Bentonite Bottom-up}

The bottom-up slicing from the Kawkawlin Bentonite used the parameters established during the previous "Dundee" slicing. These parameters include the natural neighbor gridding algorithm, a three APIU contour interval and the "blue" color scale. As the Kawkawlin Bentonite is a chronostratigraphically significant surface, the images generated from the bottom-up slicing represent the paleogeography of the sediment 
natural radioactivity during late Detroit River deposition (Wylie, 2002; Wylie and Huntoon, 2003).

\section{Part 3}

\section{Rogers City and Dundee Tops Data}

A complete analysis of the "Dundee" resulted in the separation of the Rogers City Limestone from the Dundee Limestone for the final slicing. The Rogers City interval across the basin was difficult to identify based solely on gamma ray logs. Consequently, the extent of the unit in this study was modeled after a map of the Roger City thickness prepared by Cohee and Underwood (1945) based on well cuttings. From this correlation, 216 of the 295 total wells were identified as containing the Rogers City Limestone. The predetermined "Dundee" top pick was used as the top surface for the Rogers City and the lower surface, the new Dundee Limestone top, was estimated based on the Cohee and Underwood (1945) isopach values.

Baltrusaitis (1974), in his study of the Kawkawlin Bentonite and its chronostratigraphic significance, stated that the top of the Rogers City Limestone "very closely represents a time line." If this statement is true, the slicing results from the Rogers City top pick should closely represent time surfaces during deposition. Curran and Hurley (1992) described the base of the Rogers City as a sequence boundary in the center of the basin. This suggests a possible basin-wide chronostratigraphic basal surface although slices from the bottom of the Rogers City can only represent approximate time surfaces as this surface was estimated.

From the Dundee and Rogers City correlative surfaces, structure contour and isopach maps were created. The Rogers City and Dundee structure contour maps are 
shown in Figure 15 and 16 respectively. The shape of the Dundee structure contours are similar to the structure contour map previously published by Catacosinos et al., 1991. The Rogers City and Dundee isopach maps are shown in Figures 17 and 18 respectively. Curran and Hurley (1992) published an isopach map similar in shape to the Dundee isopach map.

The location of each contact from tops picks described in the above sections is illustrated in relation to one another on a SW-NE cross-section (Figure 19). This figure shows the thickening of the Rogers City and Dundee toward the northeast and the pinching out of both the Bell Shale and the Rogers City units toward the southwest. The disjointed Kawkawlin Bentonite surface is also demonstrated by the absence of the gamma ray "peak."

\section{Slicing using Slice 2: Rogers City and Dundee Intervals}

After separating the Rogers City Limestone from the Dundee Limestone, both units were sliced using the top-down and bottom-up methods. The slicing parameters used were equivalent to those described for the Kawkawlin Bentonite. Recent work by Curran and Hurley (1992) stated that the contact between the Rogers City and Dundee Limestone is a disconformity, indicating that the slices generated from this surface should be chronostratigraphically significant if the rate of deposition remained constant throughout the basin. As stated earlier, Bloomer (1969) determined that deposition was not constant during Dundee time. Review of the Dundee Limestone and Rogers City Limestone surfaces indicates that the slices created using the WLT method should create general trends in the gamma ray amplitudes over the basin as opposed to the actual paleogeography. 


\section{Depositional Model}

The Michigan Basin's paleogeography during Dundee-Rogers City time (376-380 Ma) was approximately $20^{\circ} \mathrm{S}$ and modeling of the tropical paleoclimate illustrates that the mean temperature would have averaged $75^{\circ}$ Fahrenheit ( $24^{\circ}$ Celsius) (Golonka et al., 1994). Gardner (1974) presented a comprehensive interpretation for this Middle Devonian depositional environment using well cuttings, cores, driller's logs and gamma ray-neutron wireline log curves. In his conceptual model, the basin was divided into three zones, where sediments in the western region of the basin indicate a sabkha-lagoon environment, separated from an eastern open marine environment by a north-south trending shell bank (Figure 20A). A westward transgressing sea and an intermediate regression during Reed City deposition controlled this environmental differentiation (Gardner, 1974).

Many workers applied the Rogers City-Dundee depositional model proposed by Gardner (1974) to their own studies (Lilienthal, 1978; Bush, 1983; Fisher et al., 1988; Catacosinos et al., 1991; Howell and van der Pluijm, 1999). Prior to Gardner's (1974) division of the Michigan Basin, Cohee and Underwood (1945) illustrated a similar northsouth separation based on Dundee and Rogers City oil production. Wells west of Gladwin and Midland counties produced primarily from the Rogers City whereas, wells east of this divide produced from the Dundee. Montgomery (1986) and Curran and Hurley (1992) separated the Rogers City and Dundee depositional environments in the center of the basin. The Rogers City Limestone was described as open-marine, and the Dundee Limestone as patch reefs (Montgomery, 1986) or a shallow platform environment (Curran and Hurley, 1992). 
The most recent interpretation of the late Dundee depositional environment was presented by Taylor (2001) and closely resembles Gardner's model (Figure 20B). Taylor used a high density of well log curves to separate the sabkha from the lagoon environment and identify smaller scale features such as tidal channels, barrier islands and patch reefs. The drawback to typical models such as those shown in Figure 20 is that they only provide one generalized representation of the depositional environment whereas the WLT technique attempts to depict the evolution of depositional patterns. 


\section{Results}

A summary of the top-down and bottom-up sliced intervals is shown in Figure 21. The total number of slices created for each unit is equal to the number of feet in the thickest interval. Once the slicing exceeds the interval thickness for a particular well, the well is "dropped." The gamma ray contours are not extrapolated past the dropped wells, causing the contoured area to shrink as slicing advances. Due to this progressive loss of well control, presentation of the slice images will concentrate on the initial slices. Consequently, both slicing directions (top-down and bottom-up) were implemented to better observe changes in the gamma ray amplitude trends within the entire Rogers City and Dundee units. Each of the six intervals analyzed has a respective figure that presents slice "snapshots" generated from the WLT slicing program. The slice images are described below and are followed by a discussion of the results.

\section{"Dundee" Limestone: Top-down Slice Images}

Top-down slicing results from the contact between the Bell Shale and the "Dundee" are shown in Figure 22. The contour interval is 15 APIU and the color scale ranges from 0-150 APIU similar to the Traverse Group study. The first slice occurs at the inflection point between the shale and limestone and contains the highest gamma ray values. Progressing down toward the Detroit River Group, the gamma ray values consistently remain below 30 APIU. Based on these values, the "Dundee" is composed of relatively uniform carbonates that lack naturally radioactive material such as clay. The only trend illustrated from the slice images is the appearance of lower gamma ray values in the northern region of the basin (Figure 22, slice 25), that elongate southward (slices 
46 to 70 ) forming a trend similar in shape and position to the shoal bank in Gardner's (1974) depositional model. Reworking of carbonate sediments by wave action within a shoal environment could remove the natural radioactive material to produce a slightly “cleaner" gamma ray region.

\section{Kawkawlin Bentonite: Bottom-up Slice Images}

Bottom-up slicing from the Kawkawlin Bentonite is shown in Figure 23. The first slice occurs at the gamma ray peak and slicing continues through the Detroit River into the Dundee. The thickness of the Detroit River between the Kawkawlin Bentonite and the base of the Dundee is relatively consistent throughout the basin (Figure 19) although variations cause the slices to cut across the Detroit River-Dundee contact and ultimately become less accurate as slicing progresses away from the bentonite surface.

Selecting a set of representative slice images was difficult because the contour patterns were constantly changing. The Kawkawlin Bentonite is present in the first three slices, appearing as green contours (24-30 APIU). For most of the slices (1 to 148) the average gamma ray values range from 3-15 APIU increasing to 9-21 APIU for the remaining slices (179 to 213 ). The most prominent characteristic within the slices is a very low (3-9 APIU) or "clean" gamma ray region in the northwestern portion of the basin. This region occasionally extends toward the southeast while remaining present in the northwest. Following Gardner's (1974) interpretation of the uppermost section of the Detroit River Group, this low natural radioactive region in the northwest correlates to the location of a deep saline sea. 


\section{Dundee Limestone Slice Images \\ Dundee Top-down Slicing}

Top-down slicing of the Dundee Limestone toward the Detroit River Group is shown in Figure 24. The Dundee interval contains the greatest well control, resulting in a broadened view of the gamma ray patterns. The first slice is separated into two regions as a result of the different lithologies overlying the Dundee Limestone. The Rogers CityDundee contact is illustrated by the lower gamma ray values, whereas the Bell Shale/Traverse Group-Dundee contact in the absence of the Rogers City is illustrated by the higher gamma ray values. As the time significance of the Dundee surface is uncertain, subsequent slice images are assumed to only show general trends.

A subtle north-south linear trend down the center of the basin occurs in the first 45 slices near the top of the Dundee interval. Similar to the "Dundee" top-down slice images, this low natural radioactive region correlates to the shelf region defined by Gardner (1974) and Taylor (2001). The highest APIU values (24-30 APIU) are restricted primarily to the southeastern region of the basin (slices 1-62) and migrate toward Saginaw Bay in later slices.

\section{Dundee Bottom-up Slicing}

Slicing from the base of the Dundee Limestone toward the top of the unit is shown in Figure 25. The average gamma ray values at the base of the Dundee range from 12-24 APIU (slices 1-50) and decreases to 9-18 APIU as the slicing progresses upward through the Dundee (slices 72-185). There are no prominent and continuous trends within this interval. A reason for this may include slicing from a non-correlative surface, as the anhydrite pick is difficult to make in some areas of the basin. The environment of 
deposition during this period could also have been relatively unchanging, apart from the small shift to lower average gamma ray values while moving upward within the Dundee interval.

\section{Rogers City Limestone Slice Images \\ Rogers City Top-down Slicing}

Top-down slicing of the Rogers City Limestone is shown in Figure 26. This unit is thinner than the Dundee Limestone and consequently contains less slice images. The Bell Shale influences the higher gamma ray response near the top of the Rogers City Limestone. The first appearance of this influence is located in the eastern part of the basin, south of Saginaw Bay, in slice 10 and perhaps as early as slice 16 . Progressing toward the top of the Rogers City (slices 10 to 2 respectively), the green region advances north and westward. As the slicing continues downward (slices 31 to 70) toward those sediments deposited earliest in Rogers City time, the gamma ray values become increasingly lower (6-15 APIU). As the contour area decreases, a consistent northeast southwest trend remains in the northern part of the basin. The top-down slices for the Rogers City interval illustrate a low natural radioactive depositional environment and the possible westward transportation of increasingly siliciclastic-rich sediments during late Rogers City sedimentation.

\section{Rogers City Bottom-up Slicing}

Representative bottom-up slicing results for the Rogers City Limestone are shown in Figure 27. Slice 1 occurs at the Rogers City-Dundee contact and subsequent slices progress toward the top of the Rogers City, similar to chronological sediment deposition. 
The thickest Rogers City interval is $125 \mathrm{ft}$. If both the top and bottom boundaries for the Rogers City Limestone are time surfaces, then the top-down and bottom-up results should be identical, assuming that the thickness remains constant. Results from top-down and bottom-up slicing of the Rogers City exhibit similarities where the slices meet in the center of the thicker Roger City units. This equivalence suggests that the bounding surfaces for the Rogers City represent approximate time surfaces.

The majority of gamma ray values for the bottom-up slicing are between 9-15 APIU. The most prominent feature illustrated by the slicing is a low gamma ray trend, extending from northeast to southwest through the center of the contoured region in every slice. This follows the same trend as seen in the top-down slicing. From these combined results, the Rogers City Limestone appears to have been deposited in a relatively unchanging environment due to the small range of gamma ray values. A deviation from this uniformity occurred as more naturally radioactive material associated with Bell Shale sediments began being introduced into the basin. 


\section{Discussion}

The Dundee-Rogers City interval (Figure 22) was sliced using a color contour scale consistent with the Traverse Group study (Figure 28) to allow for their comparison. There is a marked contrast between these slice images due to variations in the gamma ray amplitudes. The Traverse Group amplitudes range between 0-150 APIU whereas the Dundee-Rogers City interval has a narrower range, 0-30 APIU. Although the contour interval for slicing can be reduced, such that a narrow range appears broader, there is a fundamental difference between these data distributions. For gamma ray values between 0-150 APIU, the end members infer a lithology change, whereas the end members for a limited range (e.g. 0-30 APIU) describe small natural radioactivity fluctuations in a more uniform lithology. Consequently, patterns observed within the Dundee-Rogers City slices are not attributed to major changes in lithology from carbonates to clastics as was shown in the Traverse Group study. The resultant patterns from changes in gamma ray amplitudes within the Dundee-Rogers City interval also do not illustrate the presence of delta features as were previously observed in the Traverse Group results. This indicates that sedimentation within the basin during Dundee-Rogers City deposition came from a non-fluvial source.

The base of the Traverse Group shares a slicing surface with the top of the Dundee-Rogers City interval. This relationship can be used to test the results from this study. The last slice image for the Traverse Group should correspond to the first Dundee-Rogers City slice. Figure 29B, from the Traverse Group slicing, illustrates the extent of the Bell Shale with the yellow-red-brown contours. The slicing images were created using proportional slicing, which averages the gamma ray values based on the 
thinnest interval to eliminate having wells "drop out" (Wylie, 2002). Thus, the blue contours indicate where the Bell Shale has pinched out and overlying Traverse Group carbonate is present. Five feet above the top of the "Dundee" is used (Figure 29A) to account for slight differences in the surface pick between the studies. The correlation between the slices images (Figure 29) implies that the WLT results are comparable to the Traverse Group results.

In addition to comparison with the Travers Group results, the slice images from this study are correlated to previously published interpretations of the Dundee depositional environment. A subtle similarity exists between the depositional environment proposed by both Gardner (1974) and Taylor (2001) and the top-down slicing for the Dundee Limestone. The location of the shell banks (Gardner, 1974) and inner shelf region (Taylor, 2001) appears as a low gamma ray trend running north-south through the center of the basin in slices $15-45$ and to a lesser extent through slice 75 (Figure 24). These same slices illustrate a consistently higher naturally radioactive region in the southeast, described as a shallow marine environment (Gardner, 1974; Taylor, 2001). Figure 30 superimposes Taylor's (2001) map onto slice 19 from the top-down Dundee Limestone results. This figure suggests that beyond Taylor's study region, the low natural radioactive trend appears to expand in the northern part of the basin. The occurrence of low naturally radioactive sediments could be attributed to reworking of carbonate material through wave action, decreasing the overall siliciclastic concentration that would typically cause higher gamma ray reading such as is present in the southeastern part of the basin. As the slices move down toward the base of the Dundee the low gamma ray trend disappears. This may be due to either a change in the 
depositional environment, supported by the lack of a north-south trend in the bottom-up slicing (Figure 25), or the result of decreased accuracy as the slicing progresses further from the bounding surface.

The bottom-up slicing results from the Kawkawlin Bentonite also indicate another subtle trend similar to Gardner's (1974) description of the depositional environment near the end of Detroit River Group deposition. The presence of a persistent low natural radioactive region in the northwestern region of the basin directly correlates with a deep saline sea associated with upper Detroit River halite sediments. This suggests a possible relationship between evaporites and carbonates that can be observed regionally using the gamma ray log curve.

Regional analysis of the limestone and dolomite within the Dundee-Rogers City interval using lithology data from the Aangstrom Precision Corporation indicates that the carbonates have equivalent average gamma ray values. Figure 8 illustrated that in some wells the dolomite produced higher gamma ray values than limestone, and additional well control and wells log curves are needed to separate these lithologies on a regional scale. Further analysis of the Dundee-Rogers City interval could also identify additional correlative surfaces, as the internal gamma ray character within the limestone units is not uniform. Slicing between these surfaces would improve the interpretation of natural radioactive sediment distribution during Dundee and Rogers City deposition. 


\section{Conclusions}

The WLT tomography technique was successfully applied to the Rogers City and Dundee Limestone in the Michigan Basin. The primary result from the suite of gamma ray log curves sliced over the Lower Peninsula of Michigan indicated a period of low natural radioactive carbonate deposition during Dundee-Rogers City time. This is in sharp contrast with the previous work on the Traverse Group by Wylie (2002) and Wylie and Huntoon (2003) that identified heterogeneous gamma ray distributions including expansion and contraction of muddy deltas in the eastern Michigan Basin at several periods in Traverse Group deposition. No comparable delta building activity is apparent in the gamma ray data for the Dundee and Rogers City Limestones.

A subtle north-south gamma ray trend within the Dundee interval was found to correlate with previous interpretations of Dundee facies tracts by Gardner (1974) and Taylor (2001). These results indicated that lower gamma ray amplitudes characterized the central shelf region during Dundee deposition. There was also a subtle correlation between the low gamma ray amplitudes stratigraphically above the Kawkawlin Bentonite and the presence of a deep saline sea. Additional analysis of internal Dundee-Rogers City $\log$ curve correlations would better define relative depositional rates and distributions within the basin and create more accurate paleogeographic trends using the WLT technique. 


\section{Future Work}

There are three areas of improvement suggested for future slicing of the Dundee and Rogers City Limestones that can also be applied to additional formations. These areas include picking slicing surfaces, normalizing log curves and slicing additional curves. In regard to this study, the contact between the Rogers City and Dundee Limestones was picked using a previously published Rogers City isopach map (Cohee and Underwood, 1945) because the pick was indistinguishable using only wireline log curves. The Kawkawlin Bentonite was also picked using only the gamma ray log curve and was often difficult or impossible to differentiate from adjacent high amplitudes. Similarly, the base of the Dundee could not be separated from the Detroit River in the southeastern region of the basin where the lithologies and subsequent gamma ray log values are equivalent. In order to improve top picks, the wireline data could be coupled with physical samples such as cores. Observing sections of core and relating their characteristics to responses on wireline curves would identify more accurate contacts to be used as boundaries for slicing.

Normalizing log curve data was addressed but performing individual well normalization in addition to identifying and adjusting all factors causing skewed log amplitudes were beyond the scope of this study. The overall normalization corrections could be minimal but currently remain unknown as most workers do not describe performing a normalization process for Rogers City and Dundee well log curves in the Michigan Basin. Normalization is important in that it could have a dramatic impact on WLT results because trends within the Dundee-Rogers City were separated by as few as 
3 APIU, indicating that even a minimal correction could alter the shape or even the presence of a trend.

In a publication on the identification of depositional environments using gamma ray logs, Rider (1990) stated that too many complications and variations exist to base interpretations solely on one log curve. This is evident in slicing the Dundee and Rogers City Limestones as the gamma ray curve does not identify all lithofacies changes. Lilienthal (1978) stated that porosity zones could be traced in the Dundee-Rogers City interval across the basin using the neutron log. Applying WLT to the neutron curve could highlight important porosity trends. The density log was useful for identifying anhydrite and slicing this curve would improve delineation of Reed City deposition. Furthermore, if lithology or facies data could be assigned values and input into the WLT slicing program, the resulting trends would improve both the Rogers City and Dundee depositional environment models. 


\section{References}

Addison, C. C., 1940, Buckeye oil field, Gladwin County, Michigan: The American Association of Petroleum Geologists (AAPG) Bulletin, v. 24, n. 11, p. 1950-1982.

Baltrusaitis, E. J., 1974, Middle Devonian bentonite in Michigan: AAPG Bulletin, v. 58, n. 7, p. 1323-1330.

Bassett, C. F., 1935, Stratigraphy and paleontology of the Dundee Limestone of southeastern Michigan: Geological Society of America (GSA) Bulletin, v. 46, p. 425462 .

Beckman, W. A. Jr. and E. H. T. Whitten, 1969, Three-dimensional variability of fold geometry in the Michigan Basin: GSA Bulletin, v. 80, p. 1629-1633.

Bloomer, A. T., 1969, A regional study of the Middle Devonian Dundee dolomite in the Michigan Basin: M. S. Thesis, Michigan State University, 67 p.

Bush, C. V., 1983, Dundee fields in the central Michigan Basin: M. S. Thesis, Michigan State University, $81 \mathrm{p}$.

Catacosinos, P. A., P. A. Daniels Jr., and W. B. Harrison III, 1991, Structure, stratigraphy and petroleum geology of the Michigan basin in M. W. Leighton, D. R. Kolata, D. F. Oltz, and J. J. Eidel, eds., Interior cratonic basins: AAPG Memoir 51, p. 561-601.

Cohee, G. V., and L. B. Underwood, 1945, Lithology and thickness of the Dundee Formation and the Rogers City Limestone in the Michigan Basin: U. S. Geological Survey, Oil and Gas Investigations Map, Scale 1:1,000,000.

Curran, B. C., and N. F. Hurley, 1992, Geology of the Devonian reservoir, West Branch Field, Michigan: The AAPG Bulletin, v. 76, n. 9, p. 1363-1383.

Dewan, J. T., 1983, Essentials of Modern Open-hole Log Interpretation: PennWell Publishing Company, Tulsa, Oklahoma, 361 p.

Doheny, E. J., J. B. Droste and R. H. Shaver, 1975, Stratigraphy of the Detroit River Formation (Middle Devonian) of northern Indiana: Department of Natural Resources (DNR) Geological Survey Bulletin 53, 85 p.

Dolton, G. L., 1995, Michigan Basin Province (063) in 1995 National oil and gas assessment of the United States: USGS Central Energy Team Digital Data Series, accessed at $<$ http://certmapper.cr.usgs.gov/data/noga95/prov63/text/prov63.pdf $>$ on February 12, 2004, 36 p. 
Ehlers, G. M., and R. V. Kesling, 1970, Devonian strata of Alpena and Presque Isle Counties, Michigan: Michigan Basin Geological Society (MBGS), 130 p.

Ehlers, G. M., and R. E. Radabaugh, 1938, The Rogers City Limestone, A new Middle Devonian Formation in Michigan: Papers of the Michigan Academy of Science, Arts, and Letters (1937), v. 23, p. 441-446.

Fisher, J.H., Barratt, M.W., Droste, J.B., and Shaver, R.H., 1988, Michigan Basin, in L. L. Sloss, ed., Sedimentary cover--North American craton: U.S.: The Geology of North America, v. D-2: GSA, Boulder, Colorado, p. 361-382.

Gardner, W. C., 1974, Middle Devonian stratigraphy and depositional environments in the Michigan Basin: MBGS, Special Paper n. 6, 138 p.

Goldman, M. V., director, Einstein's Legacy- CAT Scans: Physics2000 Educational Initiative, Colorado Commission on Higher Education and the National Science Foundation, accessed at http://www.colorado.edu/physics/2000/tomography/index.html on February 20, 2004.

Golonka, J., M. I. Ross, and C. R. Scotese, 1994, Phanerozoic paleogeographic and paleoclimatic modeling maps in A. F. Embry, B. Beauchamp and D. J. Glass, eds., Pangea: Global Environments and Resources: Canadian Society of Petroleum Geologists Memoir 17, p. 1-47.

Hammack, G. W. and W. H. Fertl, 1974, How well logs can be misinterpreted: World Oil, v. 179, n. 7, p. 69-73.

Howell, P. D. and B. A. van der Pluijm, 1999, Structural sequences and styles of subsidence in the Michigan Basin: GSA Bulletin, v. 111, n. 7, p. 974-991.

Hunt, E., A. Aly, and D. Pursell, 1996, Fundamentals of log analysis, Part IV: Normalization of logs with histograms: World Oil, Oct., p. 101-102.

Kellum, L. B., 1958, The Dundee Limestone in Manistee County, Michigan: Papers of the Academy of Science, Arts, and Letters, v. 43, p. 39-49.

Landes, K. K., 1944, Porter Oil Field, Midland County, Michigan: AAPG Bulletin, v. 28, n. 2, p. 173-196.

Landes, K. K., 1948, Deep River Oil Field, Arenac County, Michigan, in Howell, J. V., ed., Structure of Typical American Oil Fields: A Symposium on the Relation of Oil Accumulation to Structure- Volume III: AAPG, p. 299-304.

Landes, K. K., 1951, Detroit River Group in the Michigan Basin: US Geological Survey Circular 133, $23 \mathrm{p}$. 
Lane, A.C., 1895, Lower Peninsula 1885-1893: The geology of lower Michigan with reference to deep boring (edited from the notes of C.E. Wright): Geological Survey of Michigan, volume V, part II, 100 p.

Lilienthal, R. T., 1978, Stratigraphic cross-sections of the Michigan Basin: DNR, Geological Survey Division, Report of Investigation No. 19, 36 p. and 89 plates.

Little, A. C., 1986, Hydrodynamic character of the Dundee Limestone in the central Michigan Basin: M. S. Thesis, Western Michigan University, 89 p.

Montgomery, E. L., 1986, Facies development and porosity relationships in the Dundee Limestone of Gladwin County, Michigan: M. S. Thesis, Western Michigan University, $81 \mathrm{p}$.

Neinast, G. S. and C. C. Knox, 1974, Normalization of well log digitizing: Log Analyst, v. 14, n. 2 , p. 18-25.

Newcombe, R. B., 1930, Middle Devonian unconformity in Michigan: GSA Bulletin, v. 41, p. $725-737$.

Newcombe, R. B., 1932, Geology of Muskegon Oil Field, Muskegon, Michigan: AAPG Bulletin, v. 16, p. 153-168.

Petroleum Technology Transfer Council (PTTC), Michigan's Oil and Gas News Industry at a Glance, May 2002, Michigan Satellite Office, Western Michigan University [referenced Michigan Oil and Gas Association (MOGA) and Michigan Department of Natural Resources, 1993, Michigan oil and gas fields 1985-1986: MDNR Geological Survey Division OFR 89-01, 310 p.], accessed at $<$ http://wst023.west.wmich.edu/mi_oilgas_sum2002.htm> on March 13, 2004.

Radabaugh, R. E., 1942, The Middle Devonian Rogers City Limestone and its gastropod fauna: Ph.D. Dissertation, University of Michigan, $152 \mathrm{p}$.

Rider, M. H., 1990, Gamma-ray log shape used as a facies indicator: critical analysis of an oversimplified methodology in A. Hurst, M. A. Lovell and A. C. Morton, eds., Geological Applications of Wireline Logs: Geological Society Special Publication , n. 48, p. 27-37.

Sanford, B. V., 1967, Devonian of Ontario and Michigan in D. H. Oswald, ed., International Symposium of the Devonian System, Vol. 1: Alberta Society of Petroleum Geologists, p. 973-999.

Schlumberger, 1986, Log Interpretation Charts: Schlumberger Well Services, 122 p.

Shaver, R. H., compiler, 1984, Midwestern basin and arches correlation chart: AAPG, Tulsa, Oklahoma, 1 p. 
Shier, D. E., 1997, A comparison of log response between logging companies and different vintages of tools: Log Analyst, v. 38, n. 3, p. 47-61.

Taylor, E. T., 2001, Stratigraphic distribution of the Rogers City dolomitization across the west-central region of the Michigan Basin (Abstract): AAPG Bulletin, v. 85, no. 8, p. 1539.

Tinklepaugh, B. M., 1957, A chemical, statistical, and structural analysis of secondary dolomitization in the Rogers City- Dundee Formation of the central Michigan Basin: Ph.D. Thesis, East Lansing, Michigan State University, 125p.

Van Dyke, K., 1997, Fundamentals of Petroleum- Fourth Edition: University of Texas at Austin, 359 p.

Wylie, A. S., 2002, Log curve amplitude slicing- Visualization of well log amplitudes for paleogeographic reconstruction of the Middle Devonian Traverse Group, Michigan: Ph. D. Dissertation, Michigan Technological University, 218 p.

Wylie, A. S. and J. E. Huntoon, 2003, Log-curve amplitude slicing: Visualization of log data and depositional trends in the Middle Devonian Traverse Group, Michigan Basin, United States: AAPG Bulletin, v. 87, no. 4, p. 581-608. 
M. Le, MS Thesis, 2004

Figures 


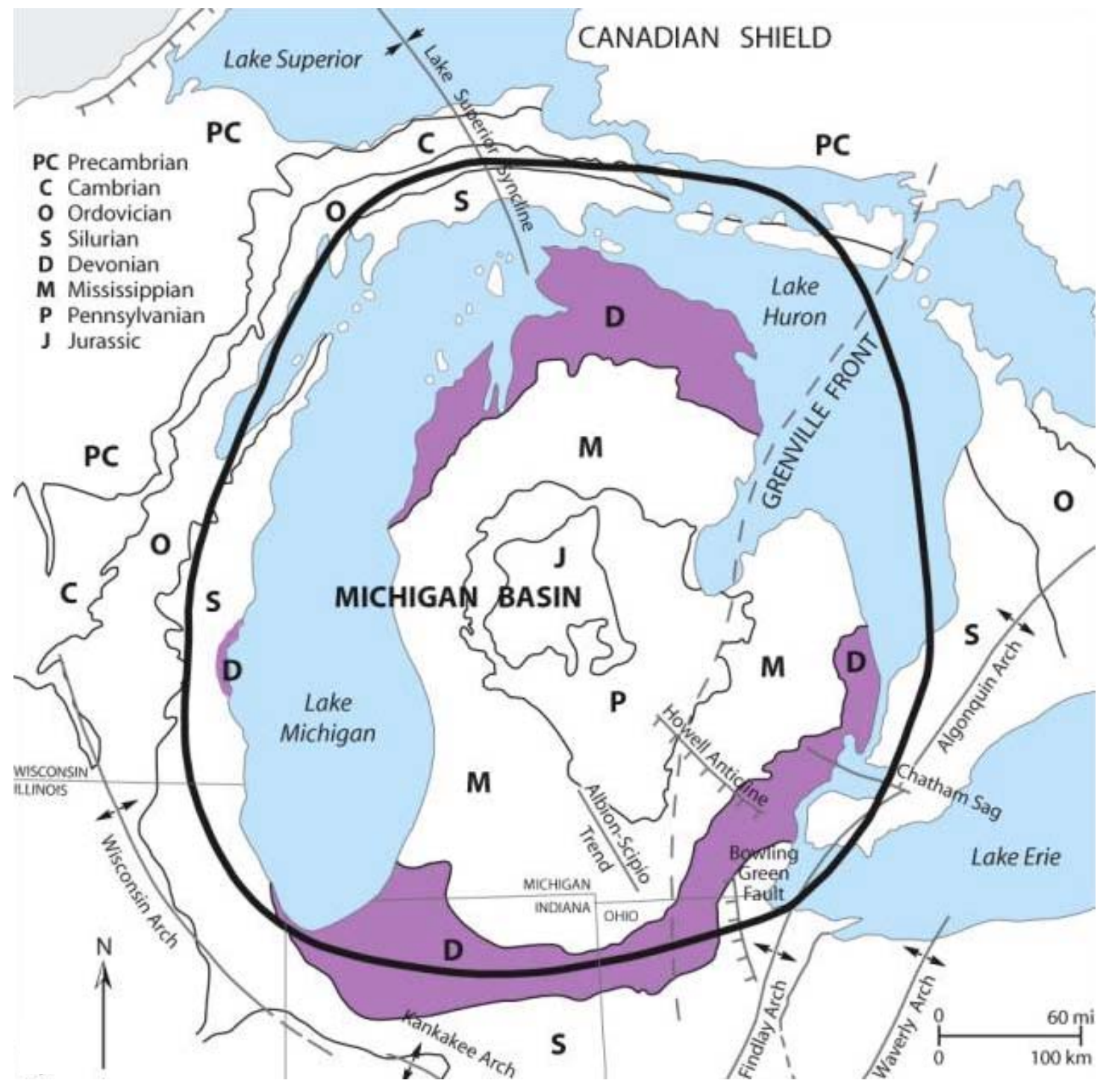

Figure 1. Location of the Michigan Basin outlined in black. The dark purple region highlights the Devonian bedrock geology (from Wylie and Huntoon, 2003). 


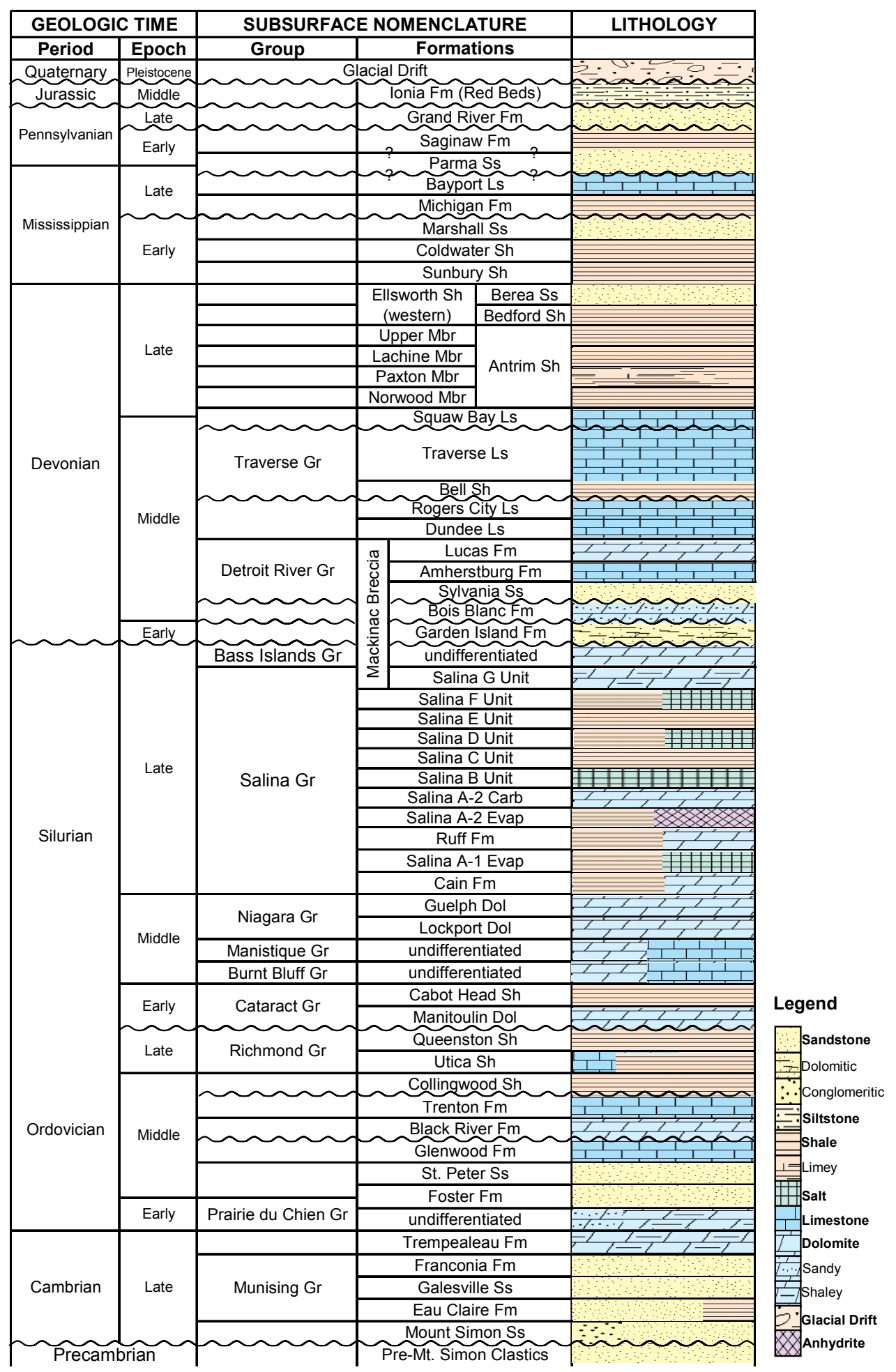

Figure 2. Stratigraphic column for the Michigan Basin, modified from the Michigan Department of Environmental Quality, Geological Survey Division and the Michigan Basin Geological Society (2000), accessed at <http://www.deq.state.mi.us/documents/deq-gsd-info-geologyStratigraphic.pdf $>$ on Jan. 15, 2004. 


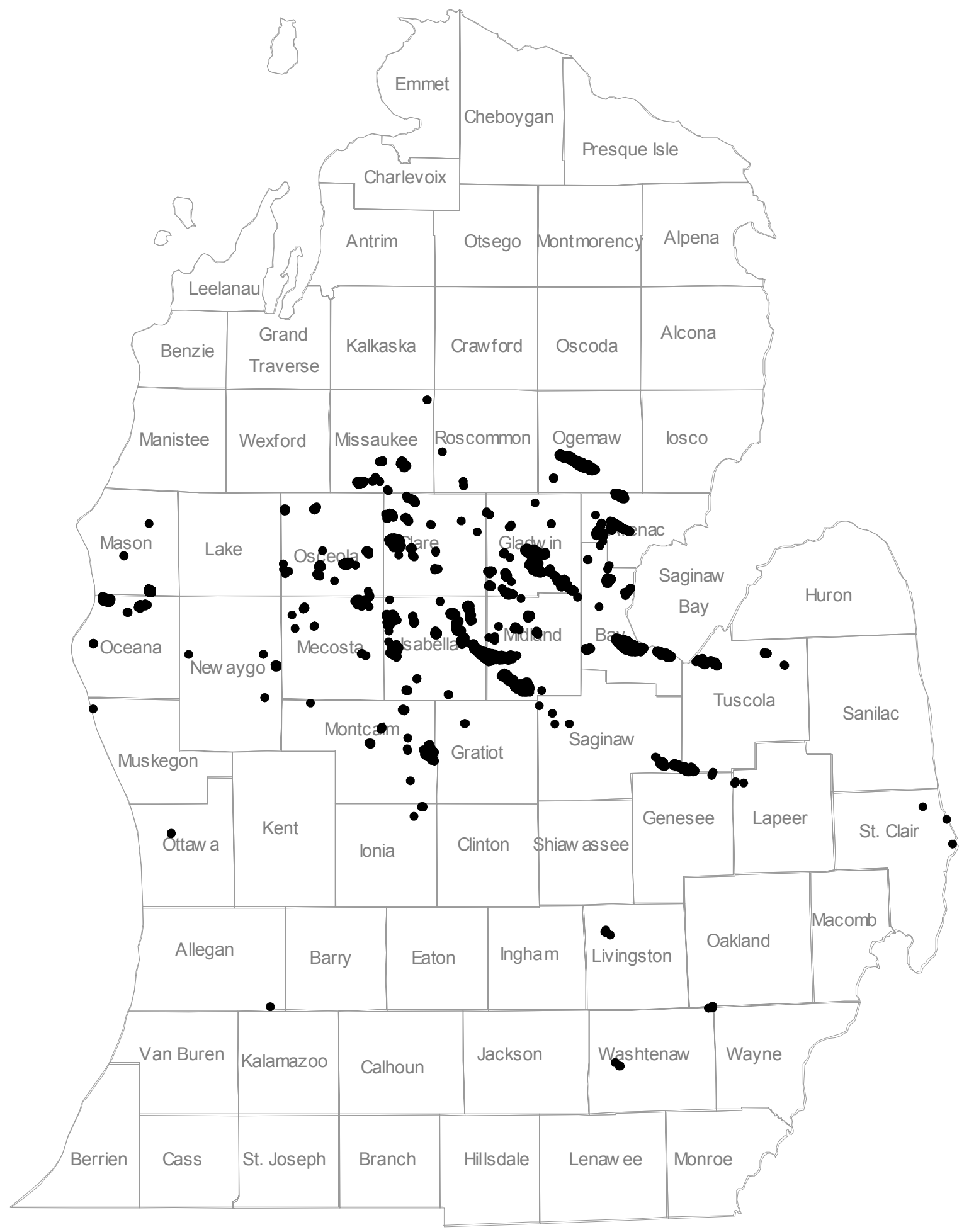

Figure 3. Location map for 2003 Dundee-Rogers City producing wells (black dots) from the Michigan Department of Natural Resources (MDNR) production database. County names are also shown for reference within the paper. 

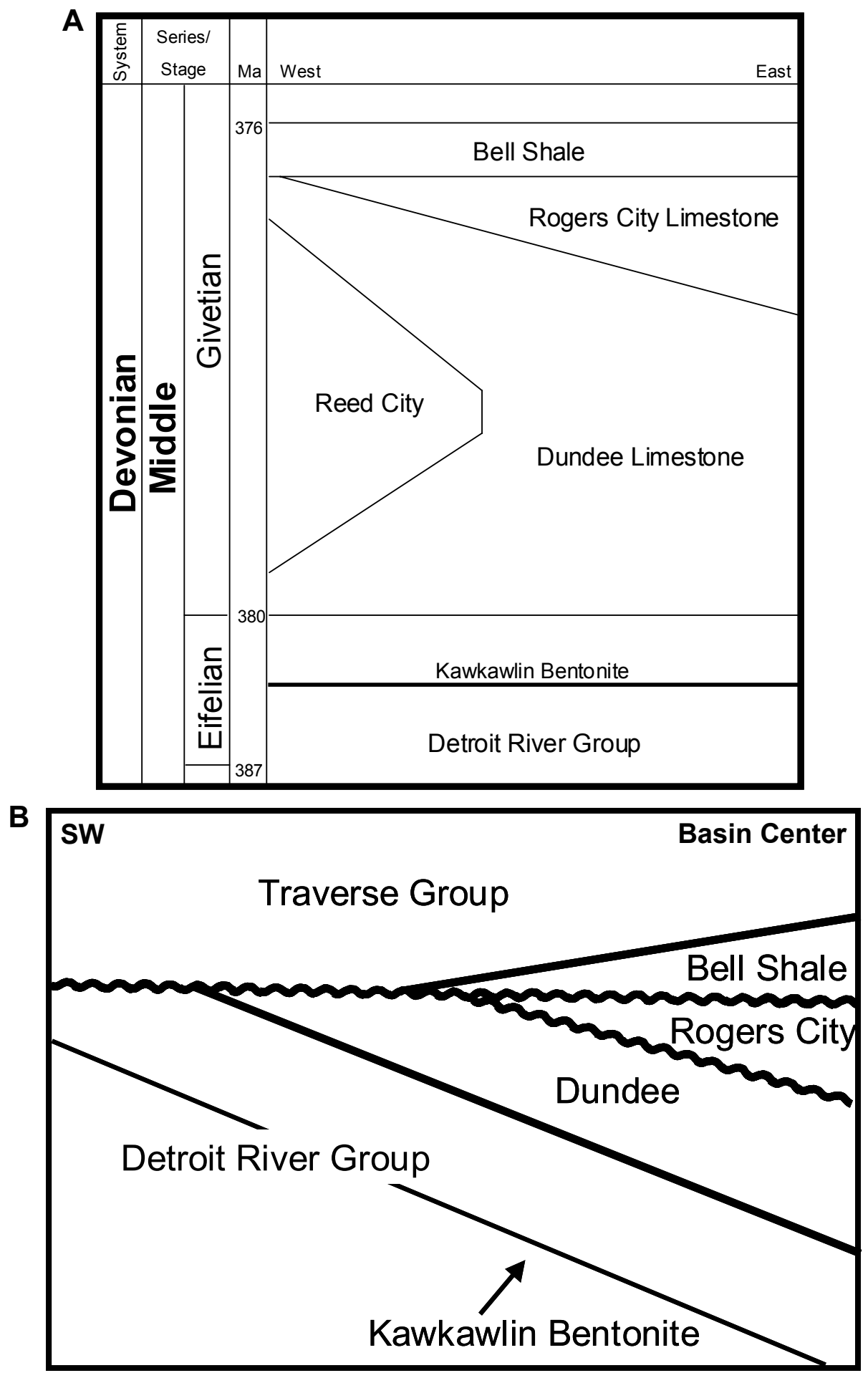

Figure 4. (A) Stratigraphy diagram for the Dundee-Rogers City and surrounding Middle Devonian units from west to east across the central Lower Peninsula of Michigan (modified from Catacosinos et al., 1991). (B) Cross-sectional stratigraphy schematic from southwest toward the center of the basin, illustrating that the Bell Shale, Rogers City and Dundee intervals are all absent in portions of southwestern Michigan. Note that the vertical scale is exaggerated. 


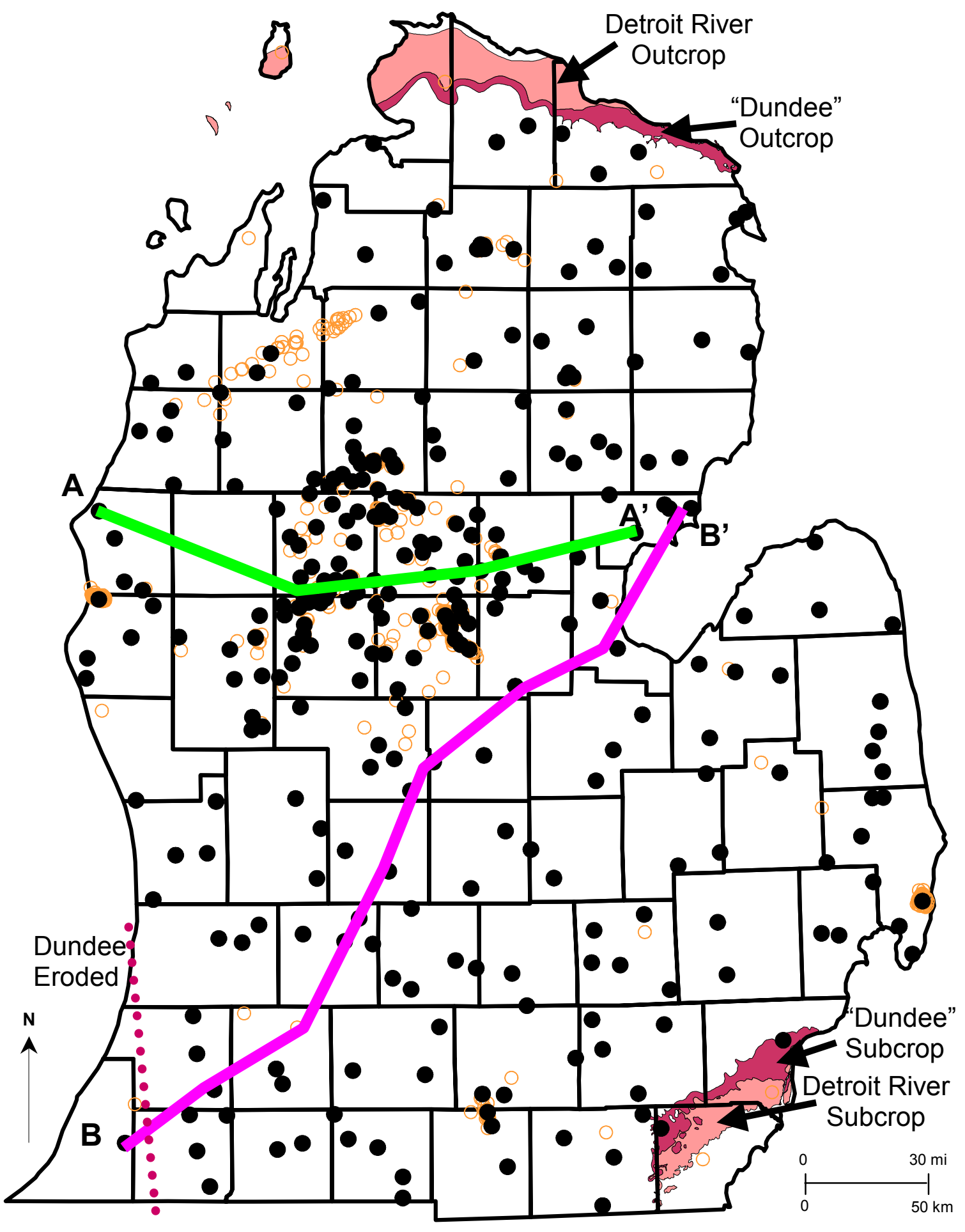

Figure 5. Outcrop and subcrop locations for the Detroit River Group and the combined Dundee-Rogers City ("Dundee") unit. A dotted line in the southwest region illustrates the absence of the Dundee Limestone due to erosion. Black closed circles represent wells used in the WLT slicing program and orange open circles locate the wells discarded before slicing. Cross-section lines are also shown for subsequent figures. 


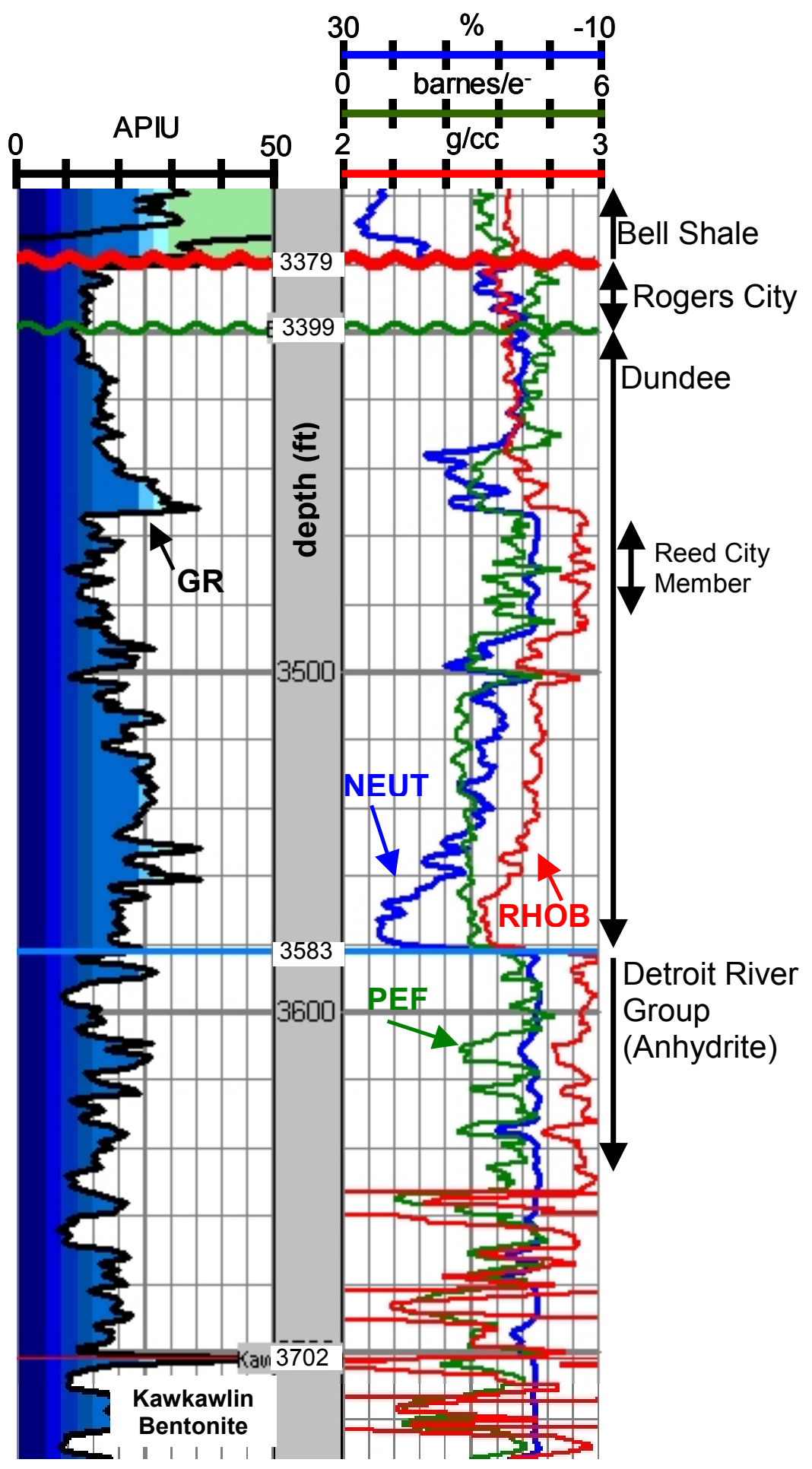

Figure 6. Example digital well log, from the Alber \#1-23 well, permit 40215 located in Mecosta County, Michigan. The gamma ray (GR) log curve is located on the left track of the well $\log$ with a color-filled amplitude. On the right track are the density (RHOB) log curve (red), neutron (blue) and photoelectric effect (green). The top picks are labeled on the depth scale in the center track. The Reed City is labeled but has no top pick because it is only a Member of the Dundee and is not present throughout the entire basin. 
A

B

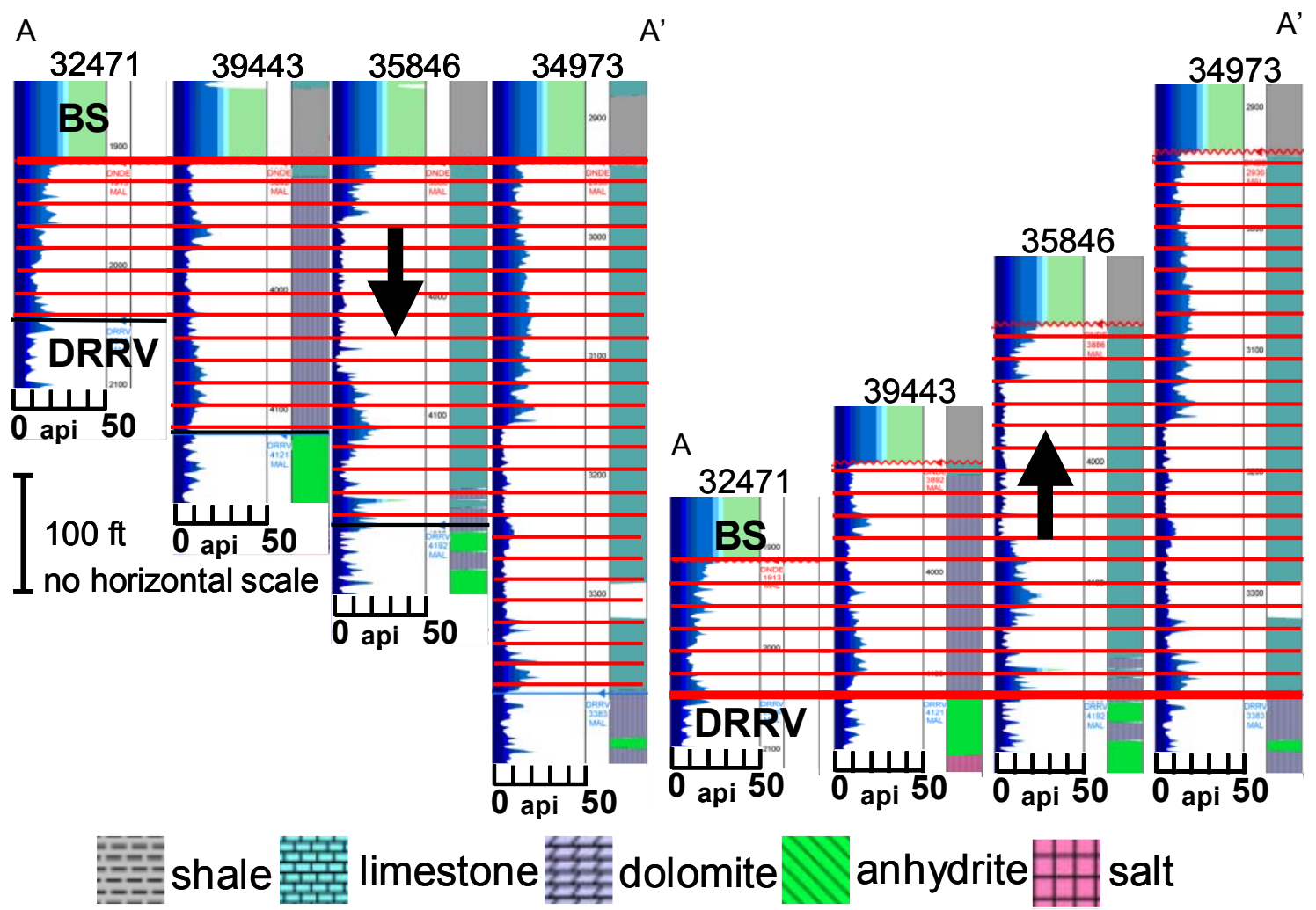

Figure 7. Illustration of the well log tomography method on the Dundee-Rogers City interval located between the Bell Shale (BS) and Detroit River Group (DRRV). Cross-section line, A-A', (Figure 5) includes four representative wells used to illustrate the slicing method. These wells from left to right, west to east across the Lower Peninsula of Michigan are: Mason County/ Carnagel Oil Associates \#3-30/ permit 32471; Osceola County/ Thompson \#1-27/ permit 39443; Gladwin County/ Dull \#3-6/ permit 35846; Arenac County/ Hagley \#1-21/ permit 34973. The gamma ray is shown on the left track of the log and the lithology is shown on the right with the lithology legend located below the figures. (A) Example of top-down slicing. The common datum point is the top of the Dundee-Rogers city interval. Slices are shown as solid red lines approximately every $20 \mathrm{ft}$. The westernmost well with the thinnest Dundee interval has the fewest slices. (B) Example of bottom-up slicing. Opposite of (A) with the common datum point at the base of the Dundee-Rogers City interval. Slices are also shown as solid red lines approximately every $20 \mathrm{ft}$. 

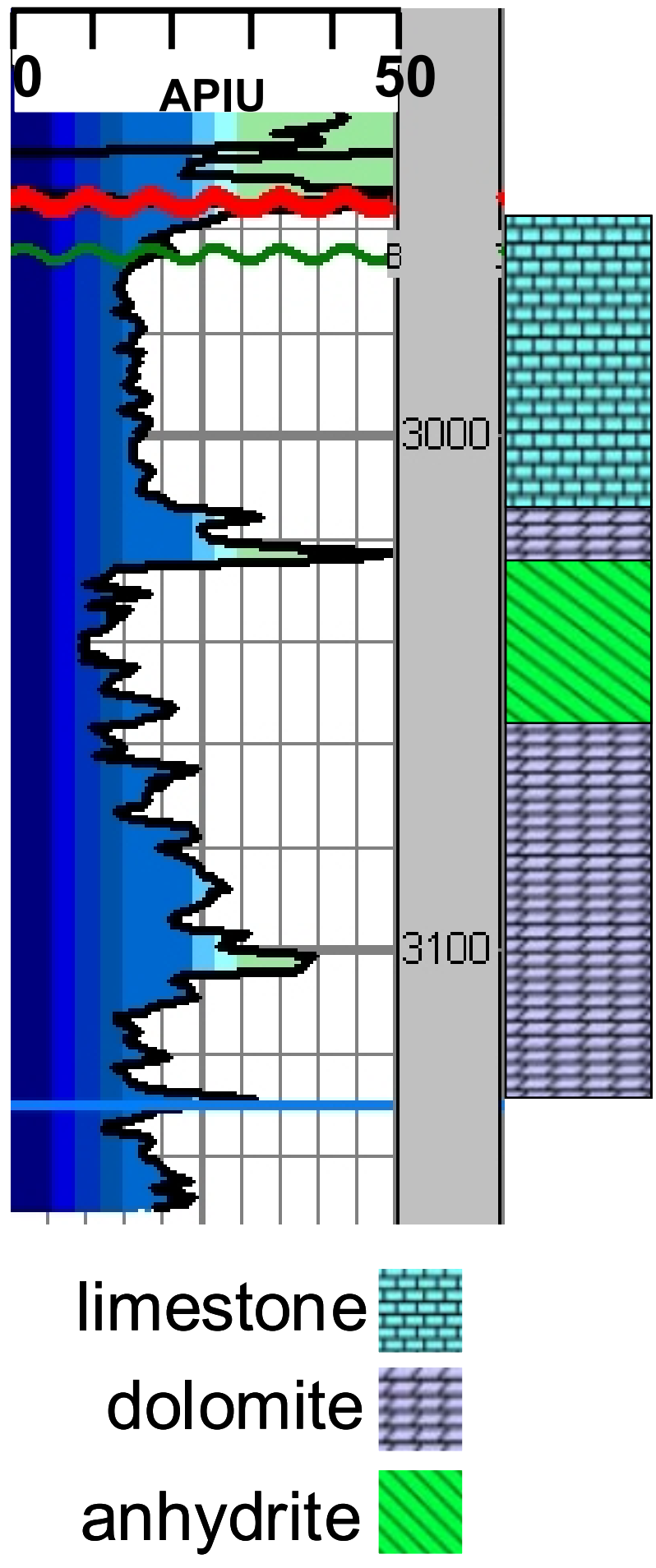

Figure 8. Gamma ray log curve of the Dundee and Rogers City interval for the Croton \#130 well, permit 41892 located in Newaygo County. The lithology as described by Gardner (1974) from core in a nearby well is shown to the right of the log curve and illustrates the gamma ray amplitudes for the different lithologies. 


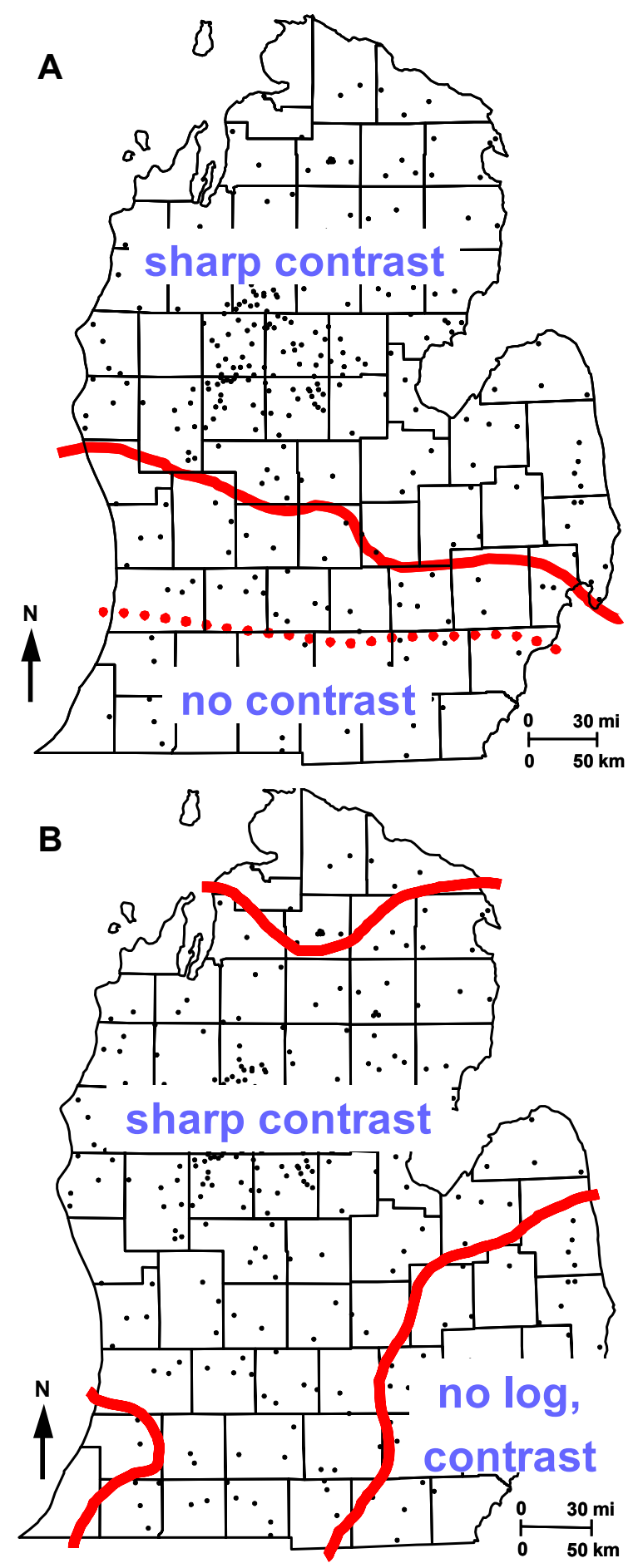

Figure 9. (A) Map showing where the Bell Shale-"Dundee" contact is easy (sharp contrast) and difficult (no contrast, absence of Bell Shale) to pick using the gamma ray log curve. The wells within the region between the solid and dotted red lines indicate a moderately difficult pick due to the thinning of the Bell Shale but a contrast between the "Dundee" and the overlying Traverse Group. (B) Map showing where the density log is present, identified by a sharp contrast between the "Dundee" and the first anhydrite within the Detroit River Group. In the southeast, the lithology changes and the "Dundee"-Detroit River anhydrite contact cannot be picked with confidence using only well log curves. 

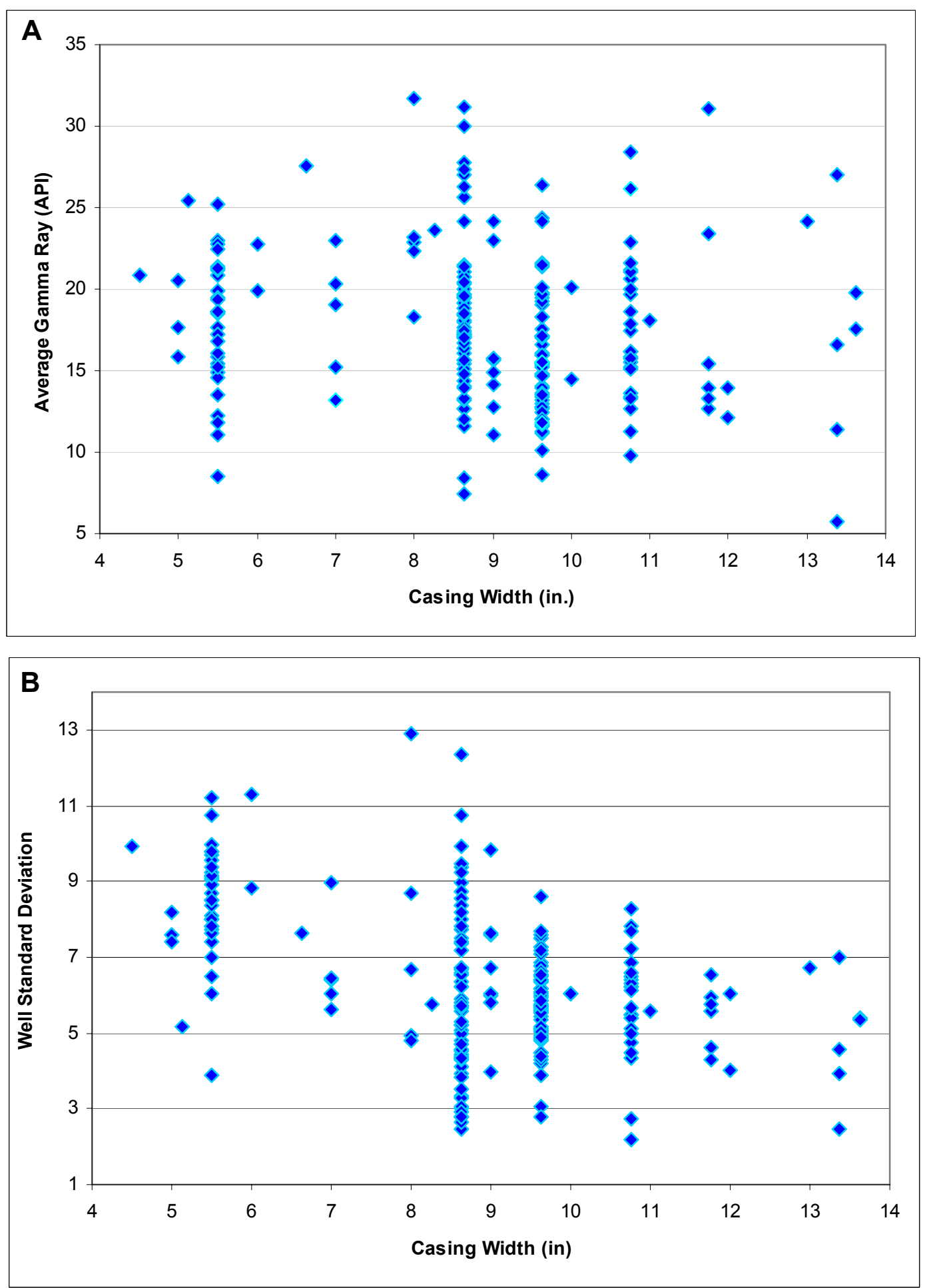

Figure 10. Cross-plot used to determine if a borehole correction was necessary. (A) Casing width (a proxy for borehole diameter) versus the average gamma ray value for the DundeeRogers City interval in 217 wells. (B) Casing width versus the standard deviation for the Dundee-Rogers City interval in 217 wells. 

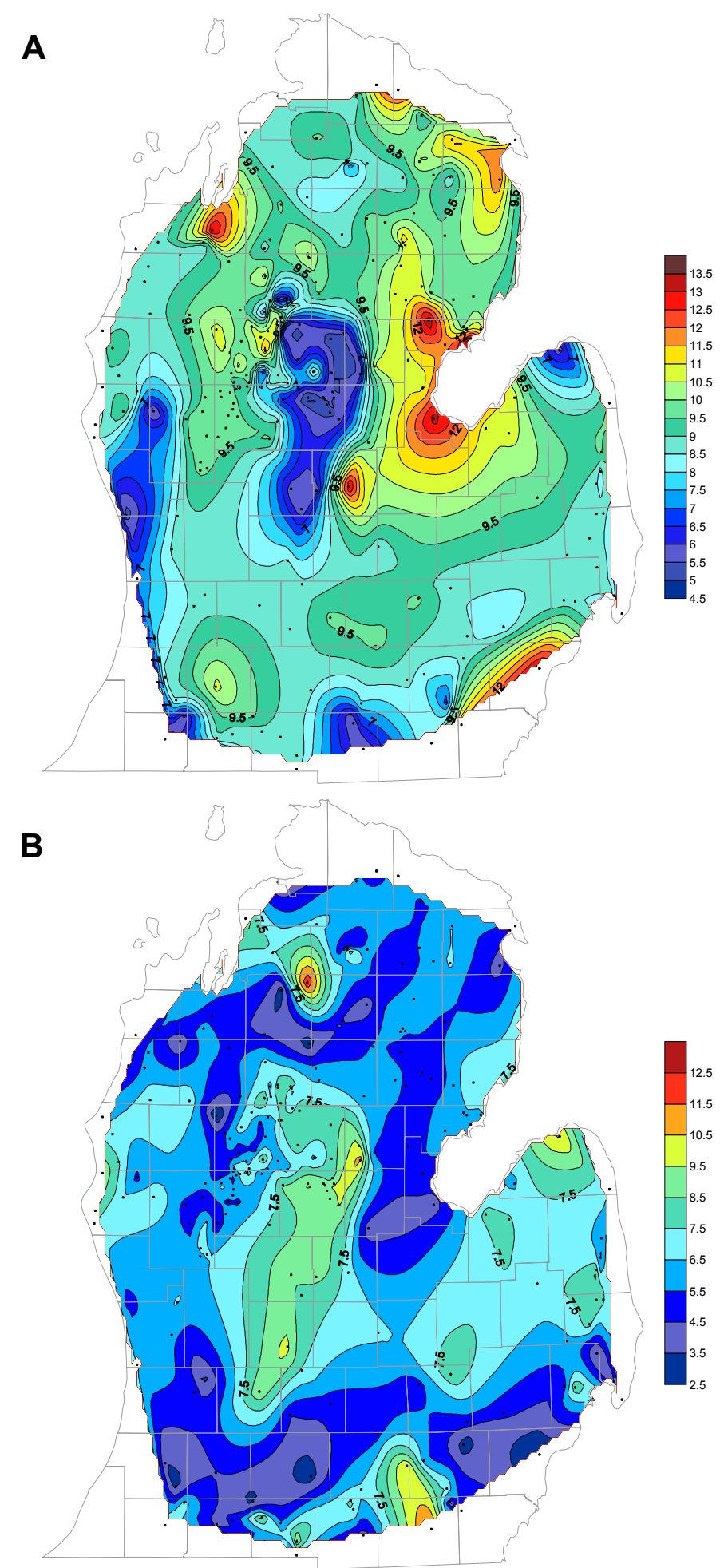

Figure 11. Contour maps illustrating the distribution of (A) casing diameter size (in) and (B) standard deviation (APIU) for the DundeeRogers City interval in 217 wells. 

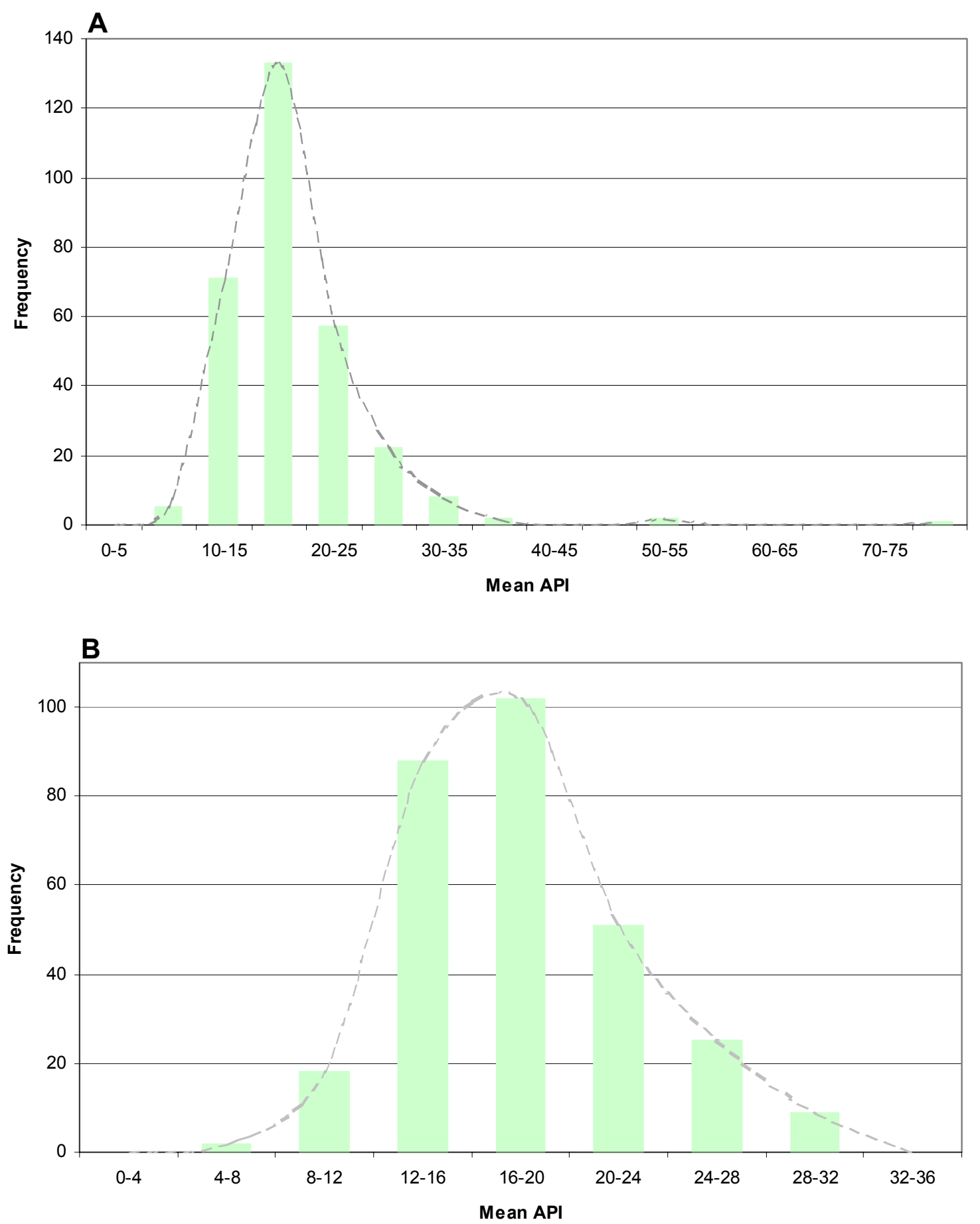

Figure 12. Frequency histogram of the average gamma ray value for (A) 302 sliced wells and (B) 295 sliced wells after those wells having a standard deviation greater than two were excluded. The bars represent the number of wells for each average gamma ray value range. The dotted curve illustrates the smoothed distribution. 


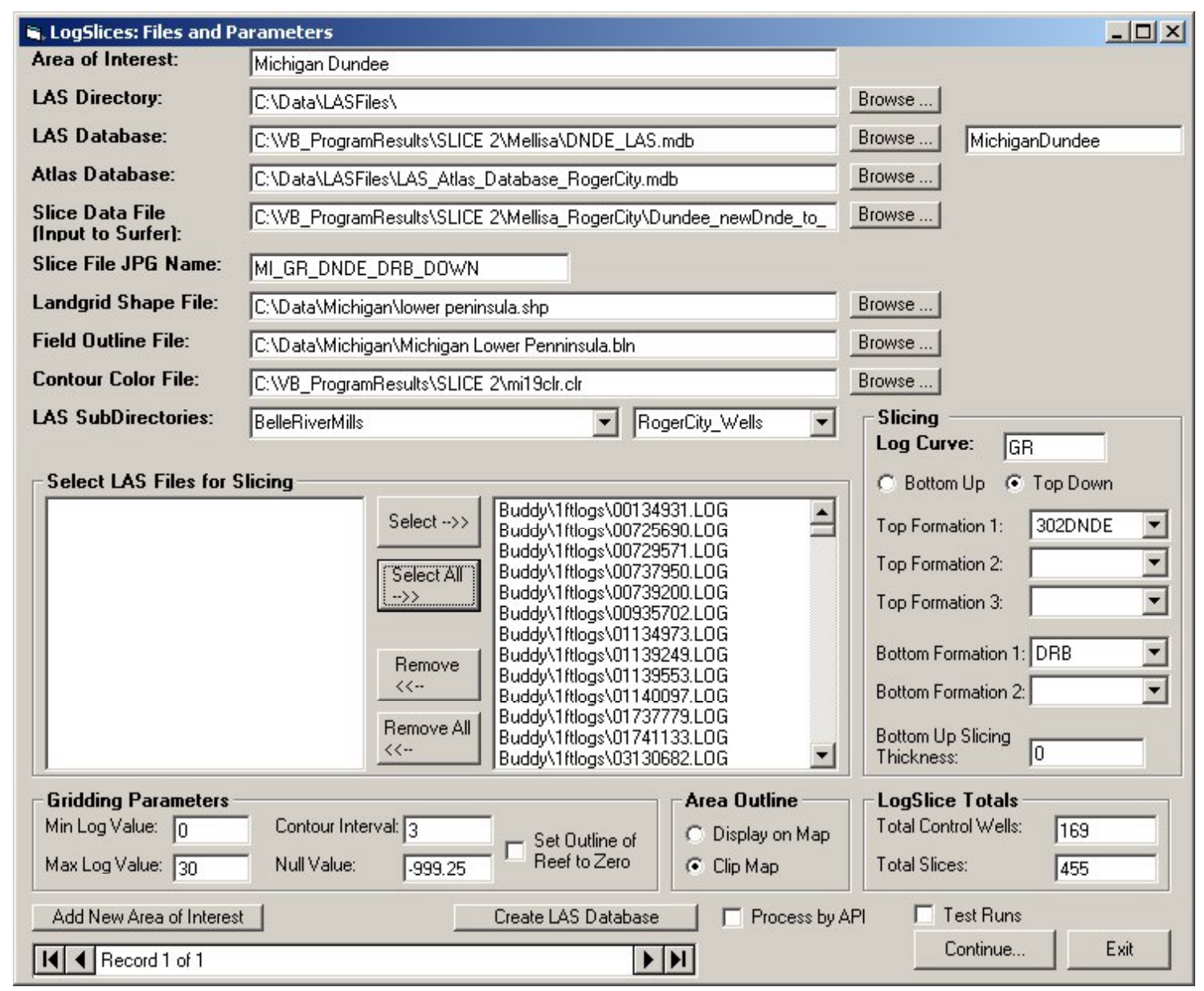

Figure 13. Screen capture of the Slice 2 Files and Parameters form. With this form, the user identifies slicing parameters such as the locations of all the necessary databases, outline of the sliced region, the curve used for slicing, slicing method (either top-down or bottom-up), the LAS files needed, surfer color contour scale, contour interval and minimum and maximum values. 


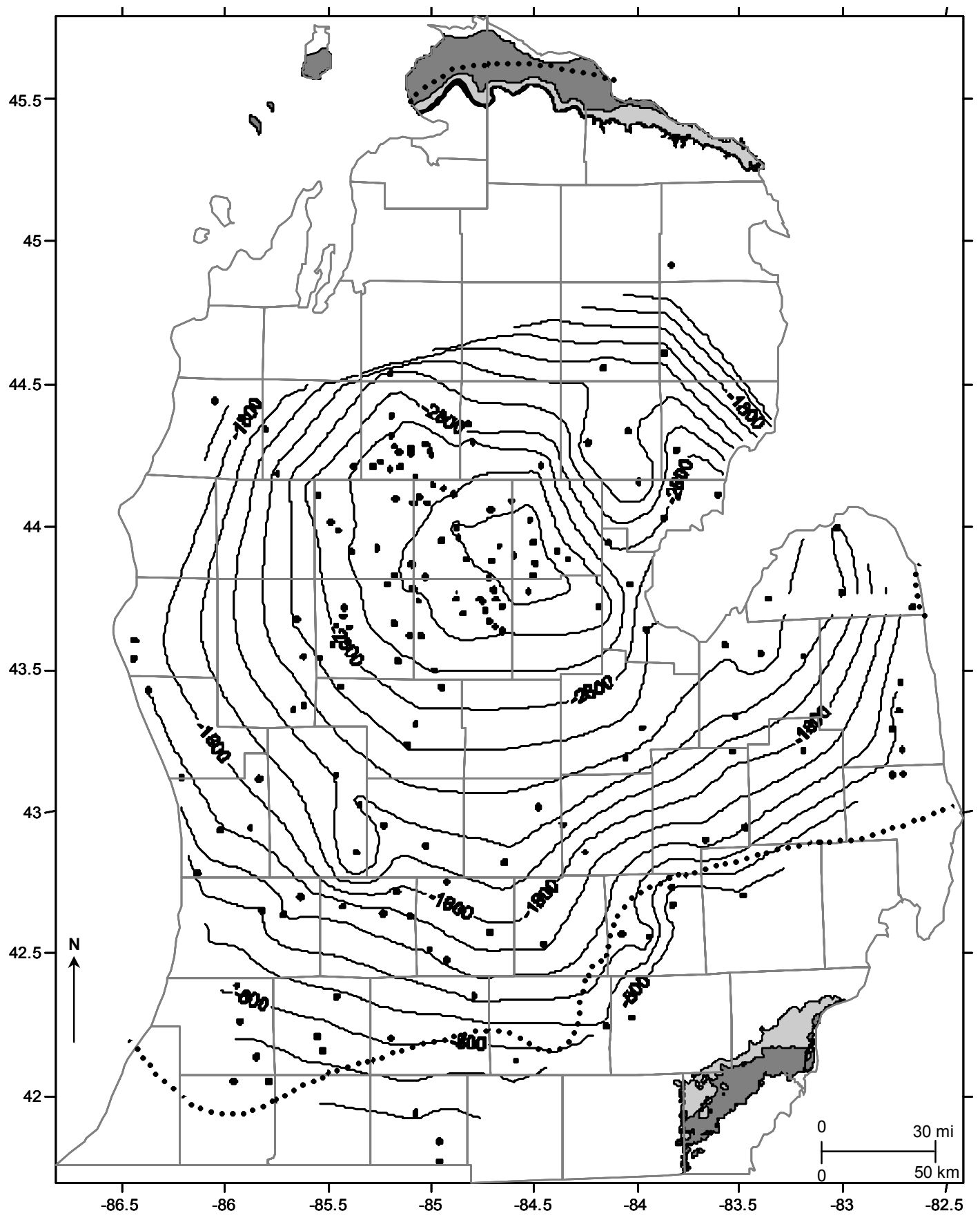

Figure 14. Structure contour map of the Kawkawlin Bentonite pick. The dotted line traces the truncation of the ash bed as defined by Baltrusaitis (1974). The black dots represent the 172 wells used in the study that had a bentonite pick on the gamma ray log curve. 


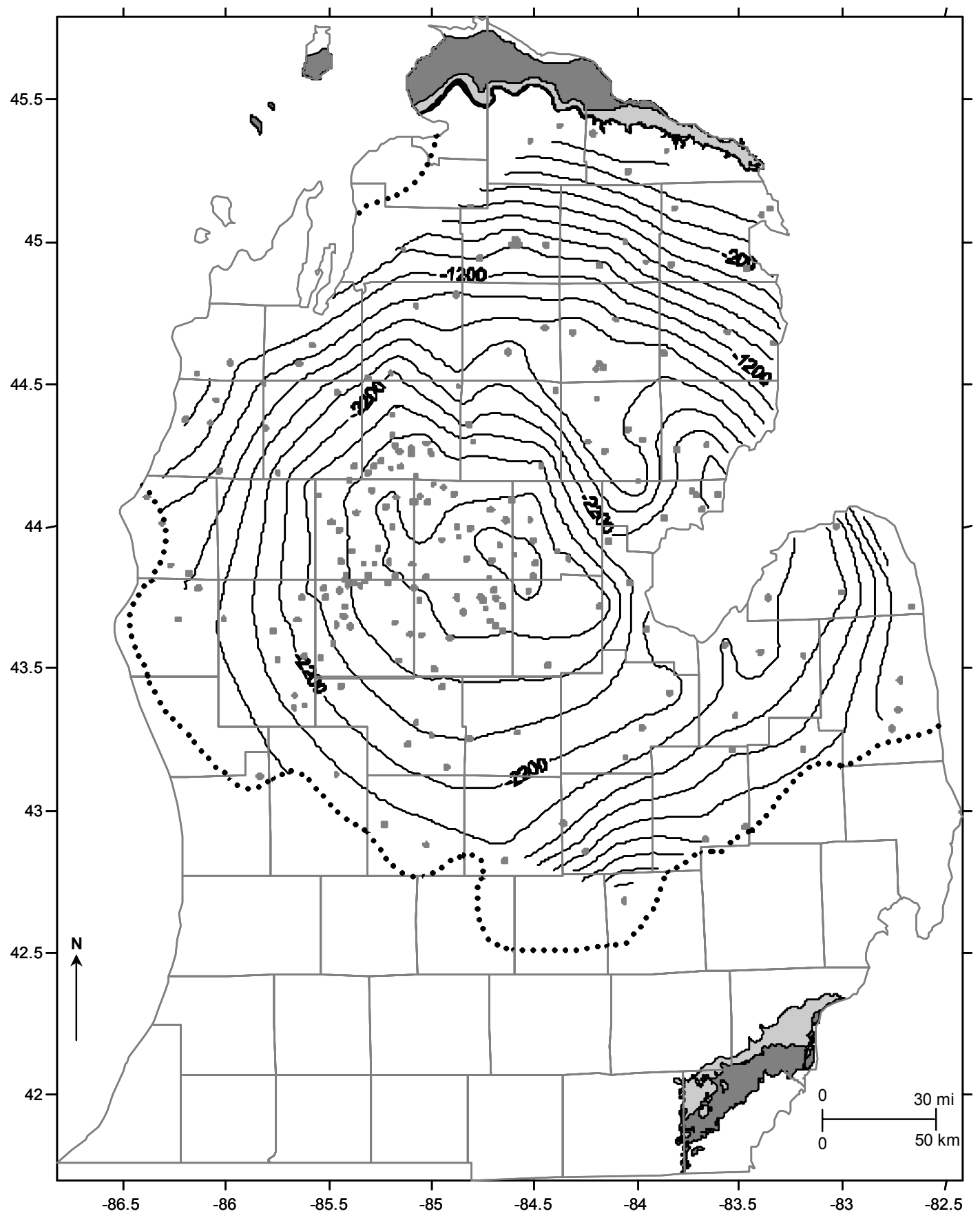

Figure 15. Top of the Rogers City structure contour map. Contour interval is $200 \mathrm{ft}$. The dotted line (from Cohee and Underwood, 1945) traces the zero-outline of the Rogers City Limestone. 


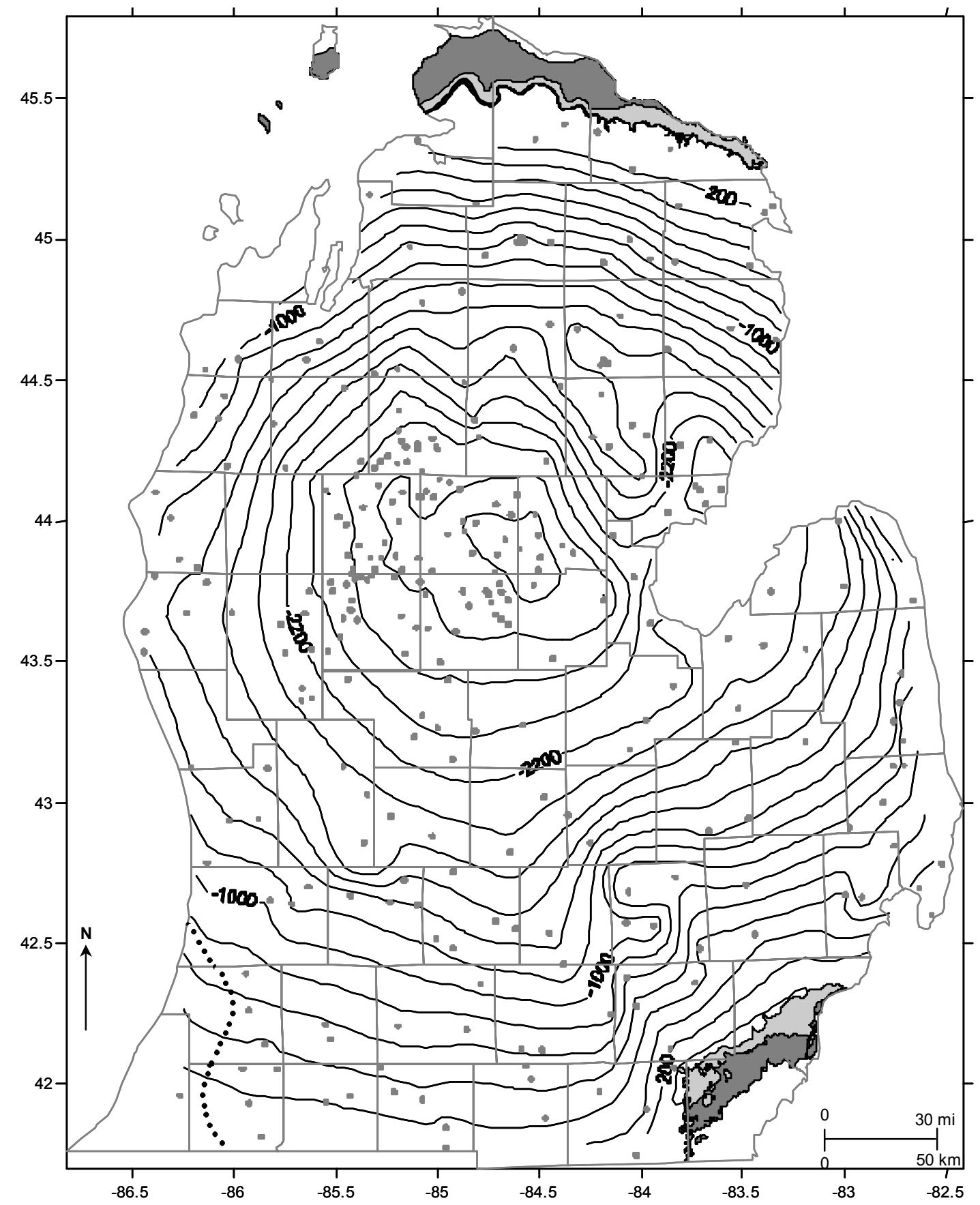

Figure 16. Top of the Dundee Limestone structure contour map. Contour interval is 200 feet. The dotted line (from Cohee and Underwood, 1945) in the southwestern counties indicates the edge of the subsurface Dundee Limestone. 


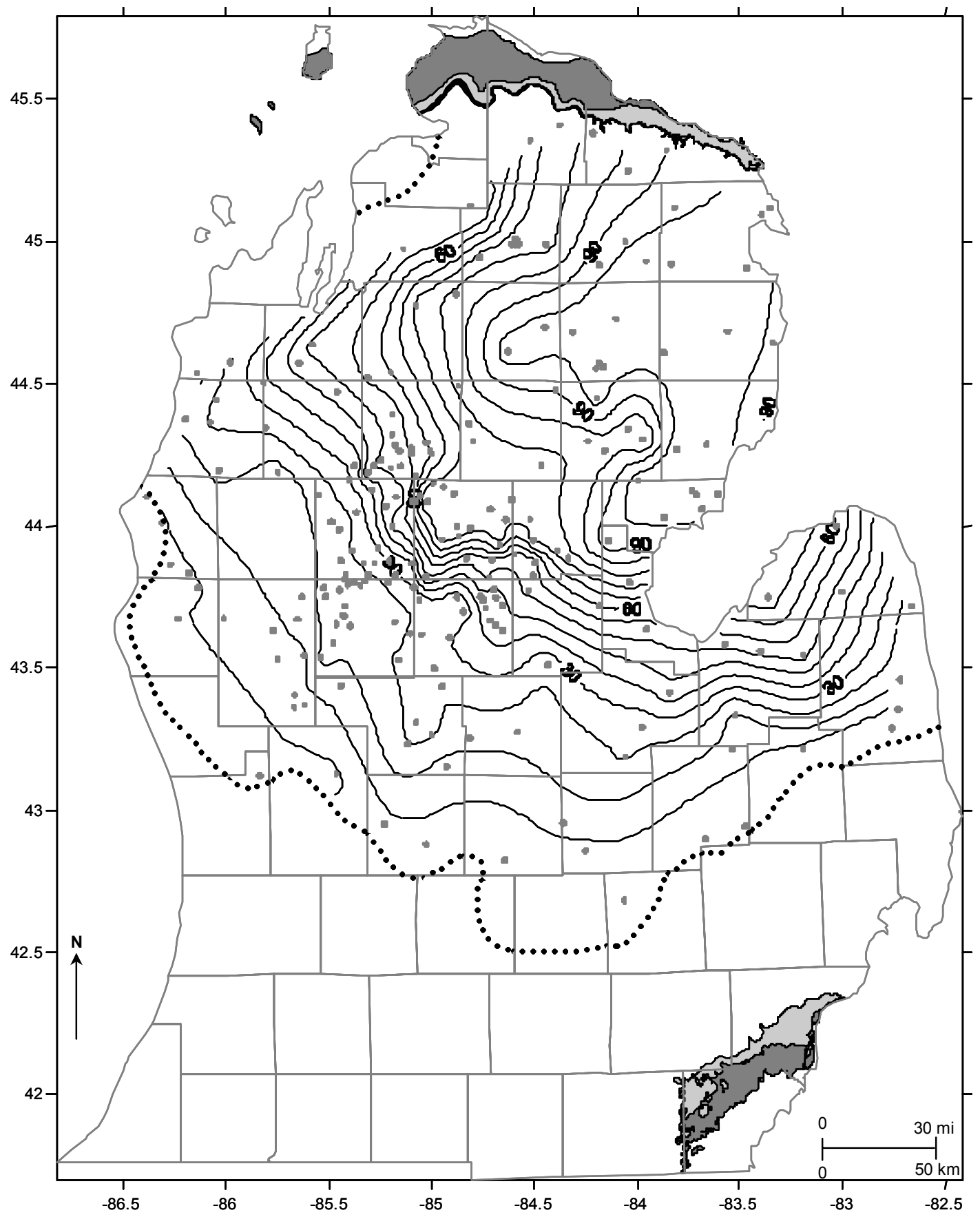

Figure 17. Isopach of the Rogers City Limestone. Contour interval is $6 \mathrm{ft}$. Zero-outline (from Cohee and Underwood, 1945) of the Rogers City is shown as a black dotted line. 


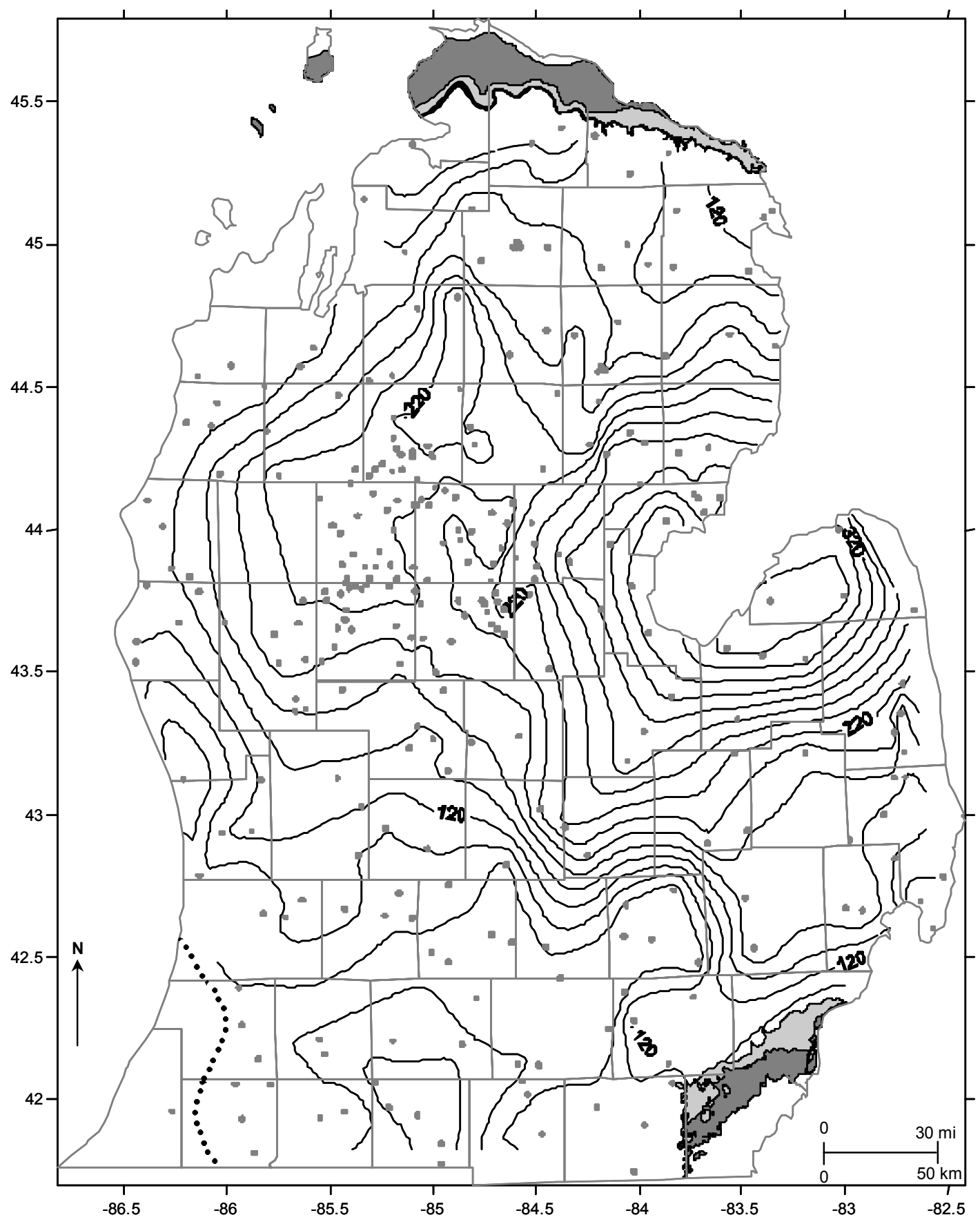

Figure 18. Isopach of the Dundee Limestone. Contour interval is $20 \mathrm{ft}$. The dotted line (from Cohee and Underwood, 1945) in the southwestern counties indicates the edge of the subsurface Dundee Limestone. 


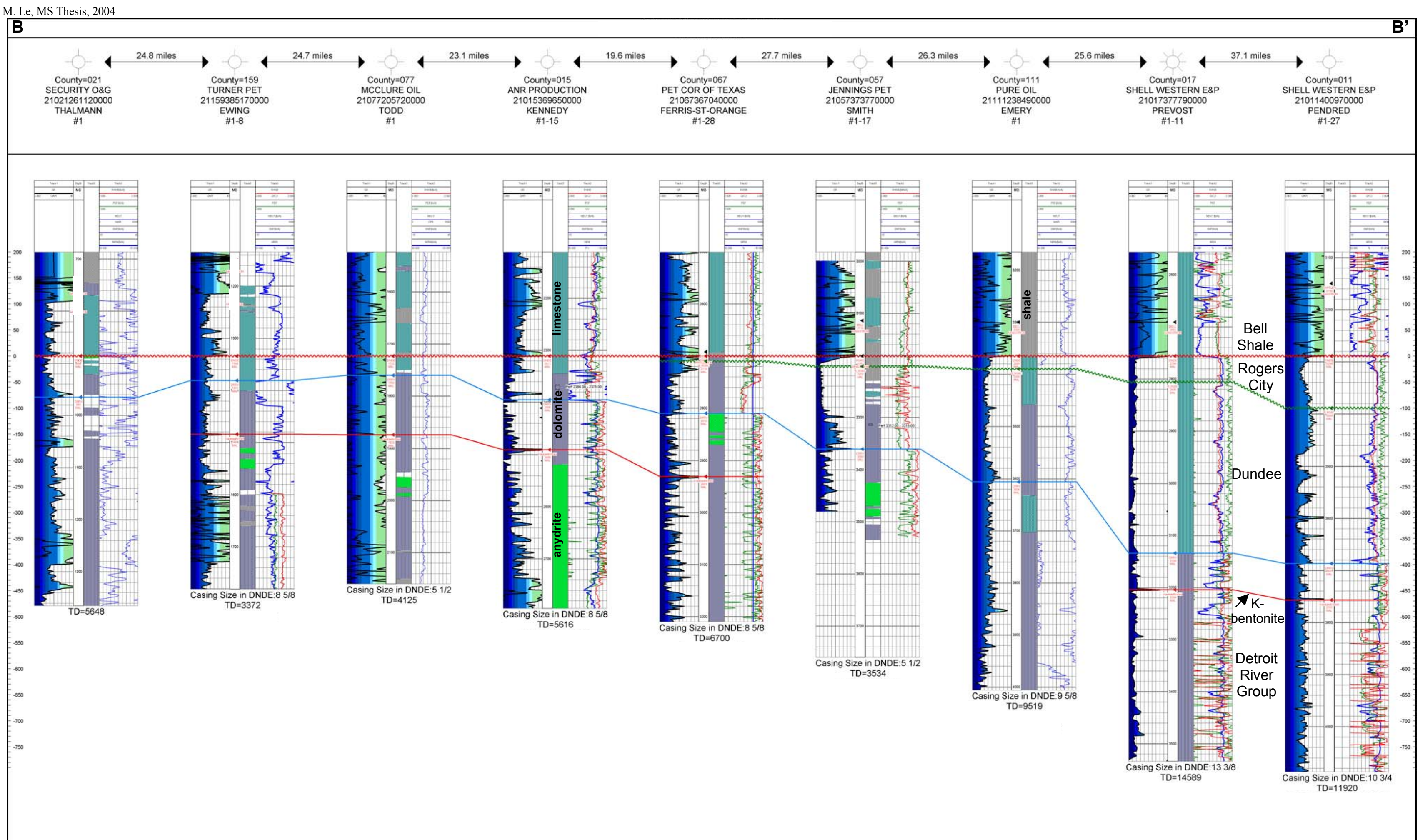

Figure 19. SW to NE cross-section from Berrien County to Saginaw Bay shown as B-B' on Figure 5. The gamma ray log curve (0-40 apiu) is shown on the right track and has a color-coded amplitude. The center track illustrates lithology data from mud logs in the Aangstrom Precision Corp database. The right track illustrates the red bulk density curve (2-3 g/cc), the green photoelectric effect curve ( $0-6$ barnes/e-) and blue neutron

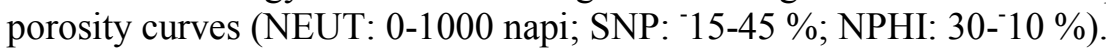




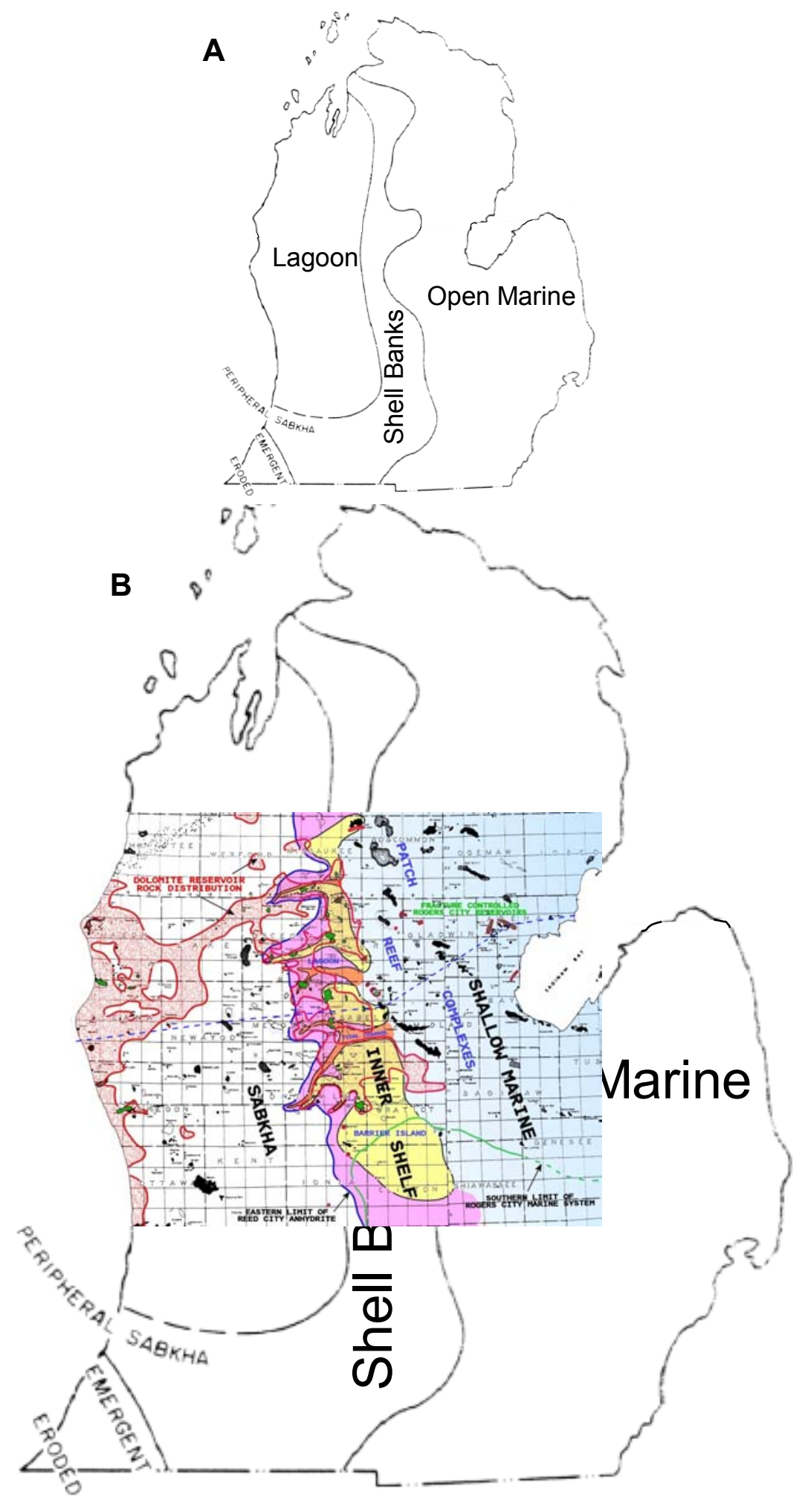

Figure 20. (A) Gardner's (1974) Dundee depositional environment model. (B) Taylor's (2001) interpretation of the Dundee depositional environment superimposed onto the Gardner model to illustrate their similarity. 
Figure 21. Diagrams illustrating the sliced intervals (shaded) and direction of slicing (arrow) presented in the results section. (A) Top-down slicing of the "Dundee" Limestone (B) top-down slicing of the Rogers City Limestone, (C) top-down slicing of the Dundee Limestone, (D) bottom-up slicing of the Rogers City Limestone, (E) bottom-up slicing of the Dundee Limestone and (F) bottomup slicing from the Kawkawlin Bentonite layer. 
A

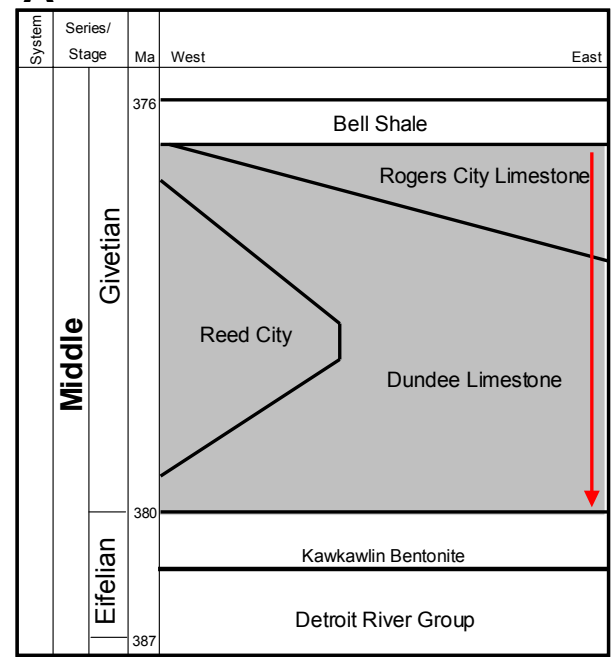

\section{B}

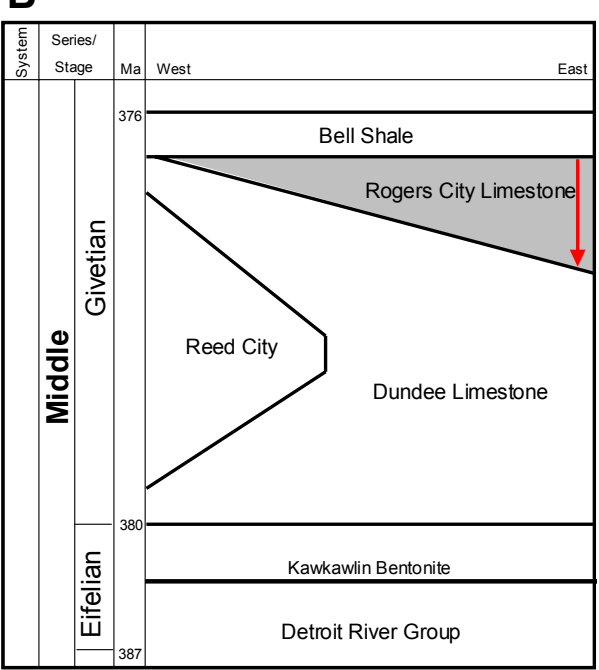

C

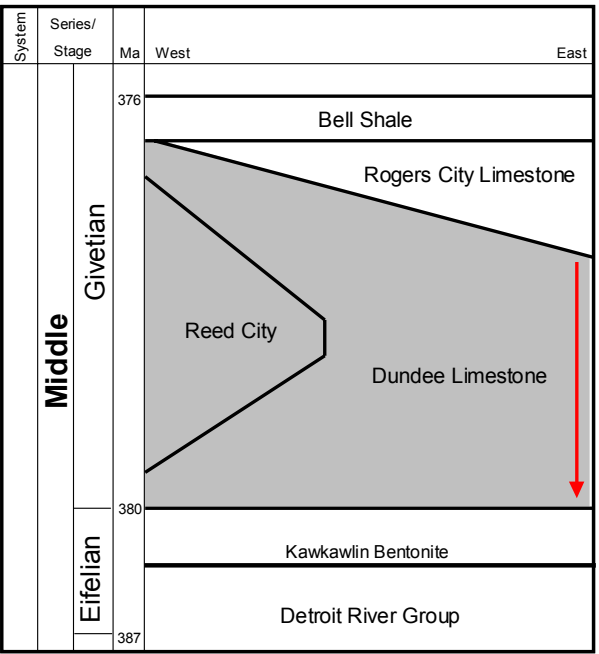

D

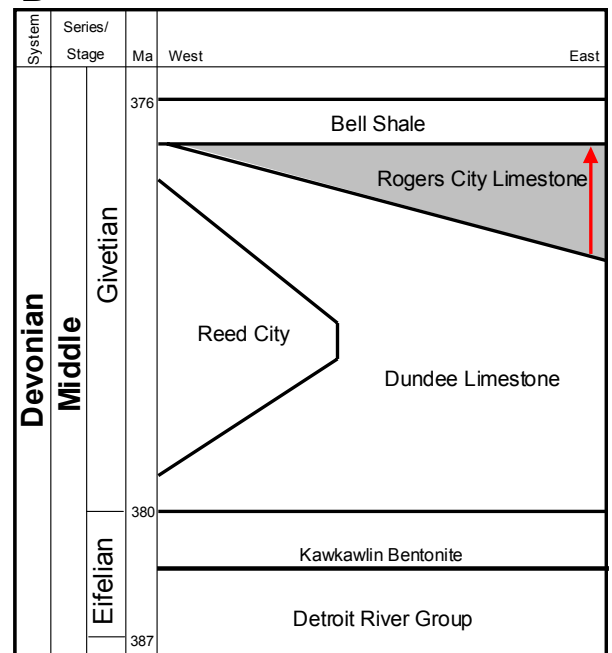

E

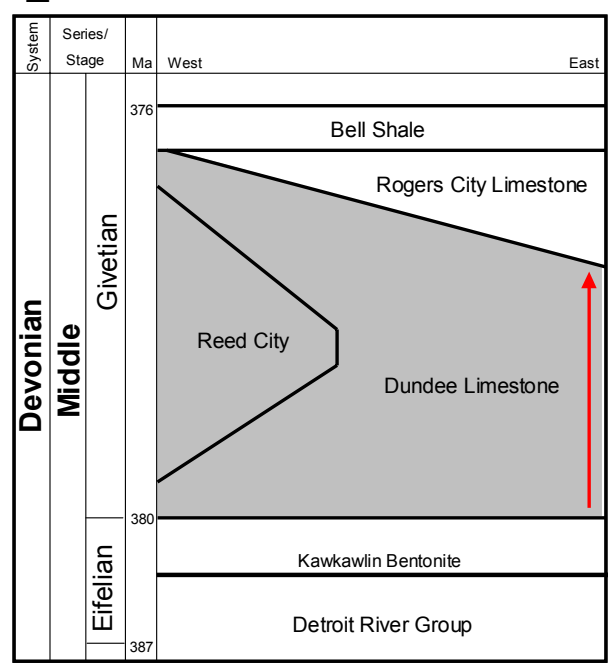

$\mathbf{F}$

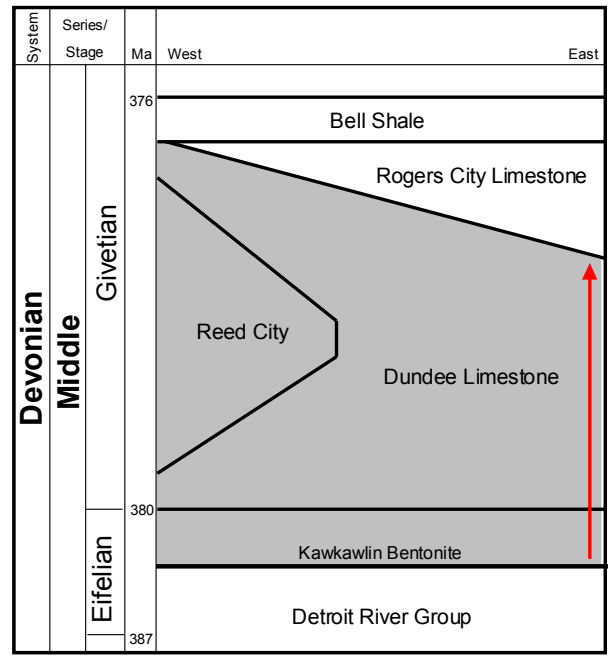




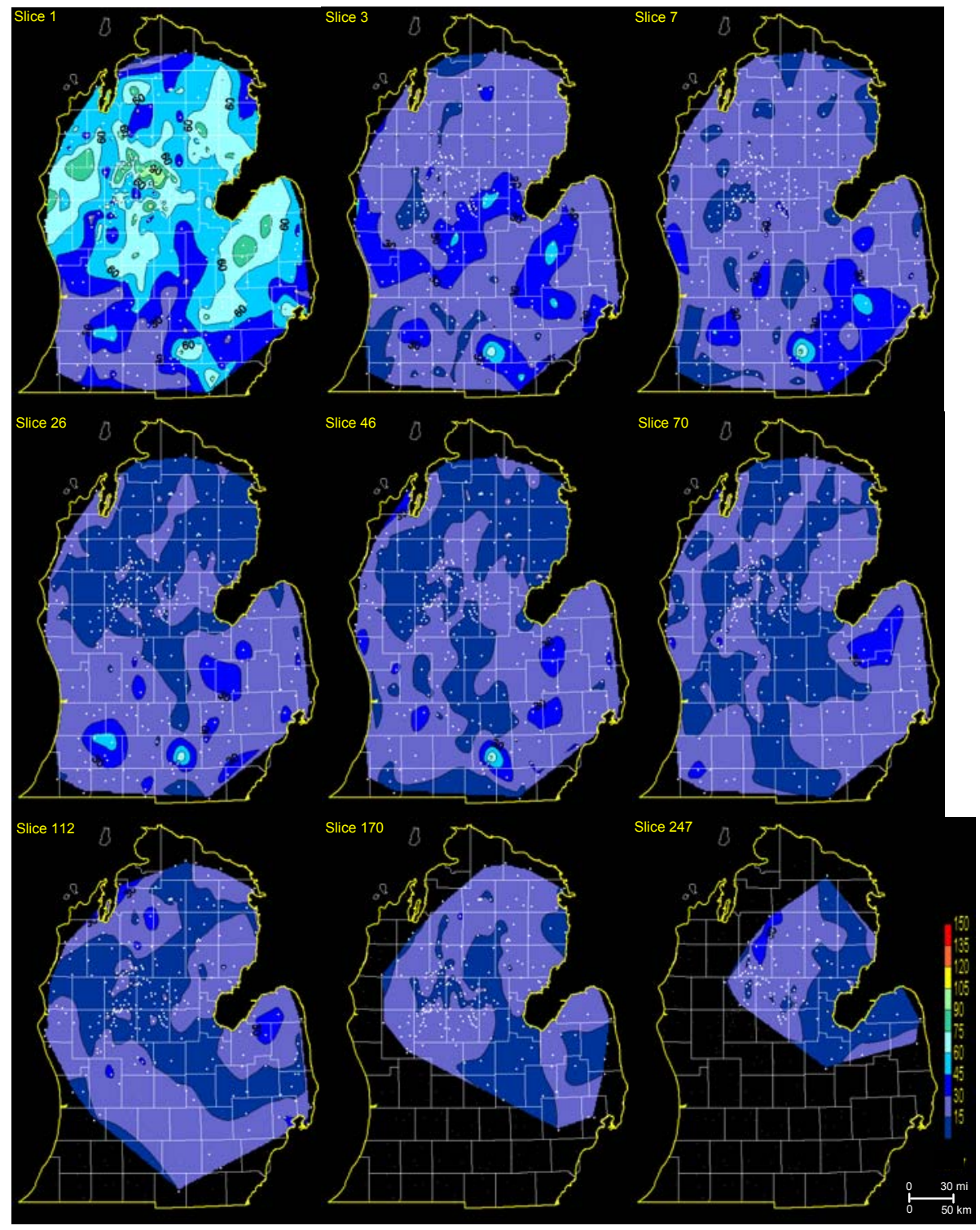

Figure 22. Representative top-down slices for the "Dundee" interval. Slice numbers correspond to the depth (ft) beneath the Bell Shale-"Dundee contact. The contour interval is 15 APIU and the white dots represent the wells used for contouring. 
Figure 23. Representative bottom-up slices from the Kawkawlin Bentonite layer toward the top of the Dundee Limestone. Slice numbers correspond to the depth (ft) above this bentonite. The contour interval is 3 APIU and the white dots represent the wells used for contouring. Note that the black color within the contoured area for Slices 1 and 3 is a product of the gridding algorithm and lies within the 27-30 APIU range. 


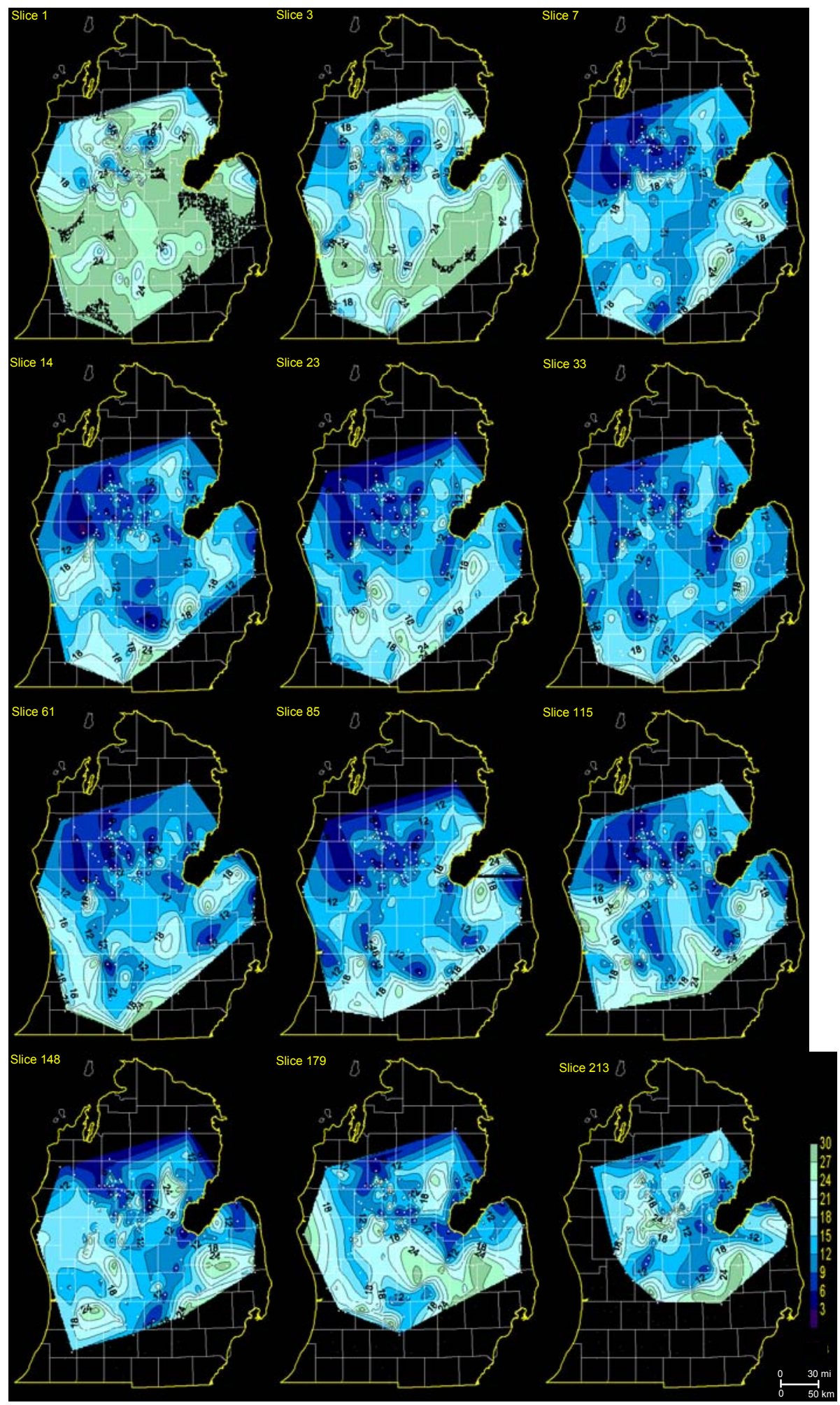


Figure 24. Representative top-down slices for the Dundee Limestone. Slice numbers correspond to the depth ( $\mathrm{ft}$ ) beneath the Dundee Limestone top pick. The contour interval is 3 APIU and the white dots represent the wells used for contouring. Note that the black color within the contoured area for Slices 1 and 3 is a product of the gridding algorithm and lies within the 27-30 APIU range. 


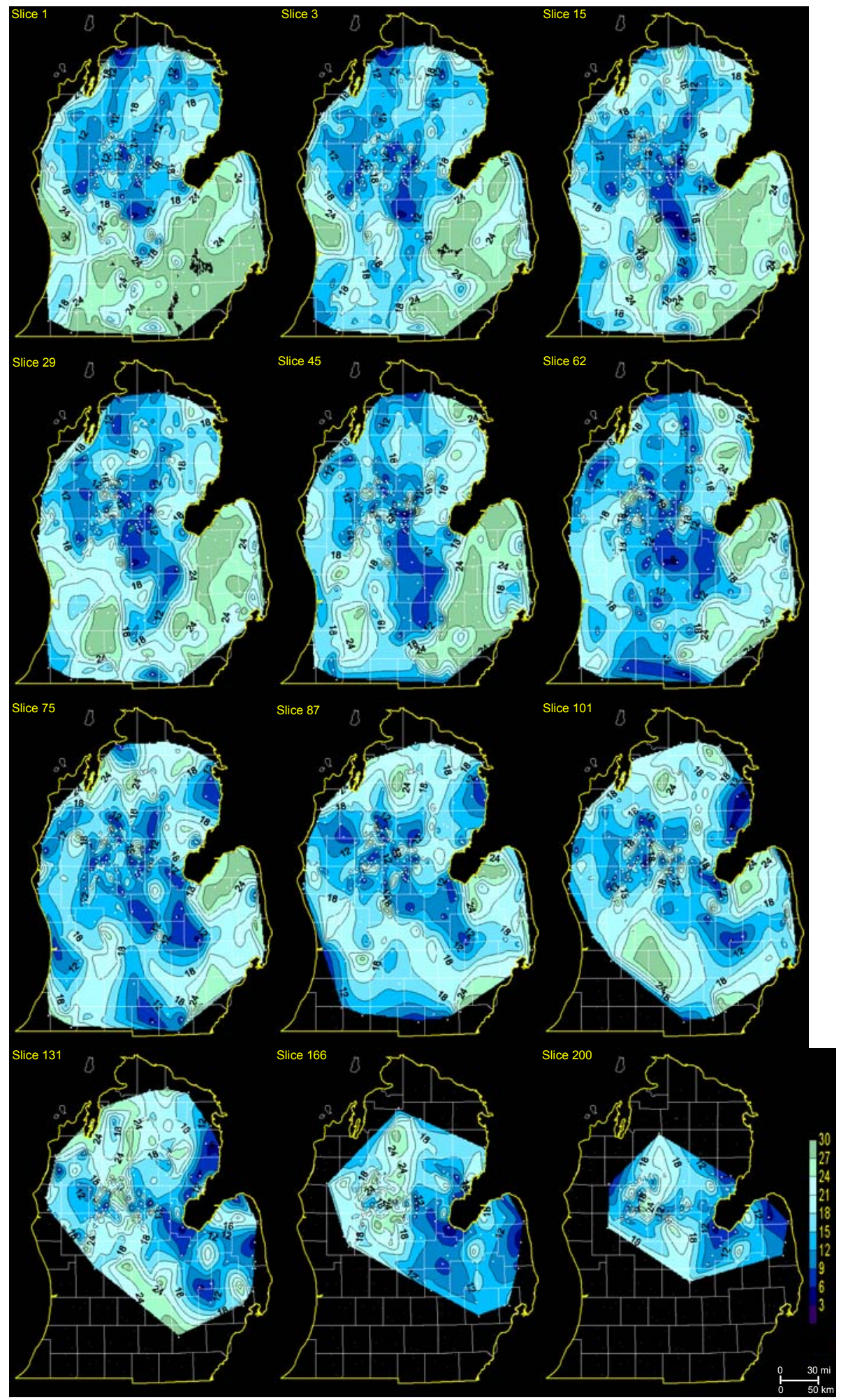


Figure 25. Representative bottom-up slices for the Dundee Limestone. Slice numbers correspond to the depth (ft) above the Detroit River Group top pick. The contour interval is 3 APIU and the white dots represent the wells used for contouring. 


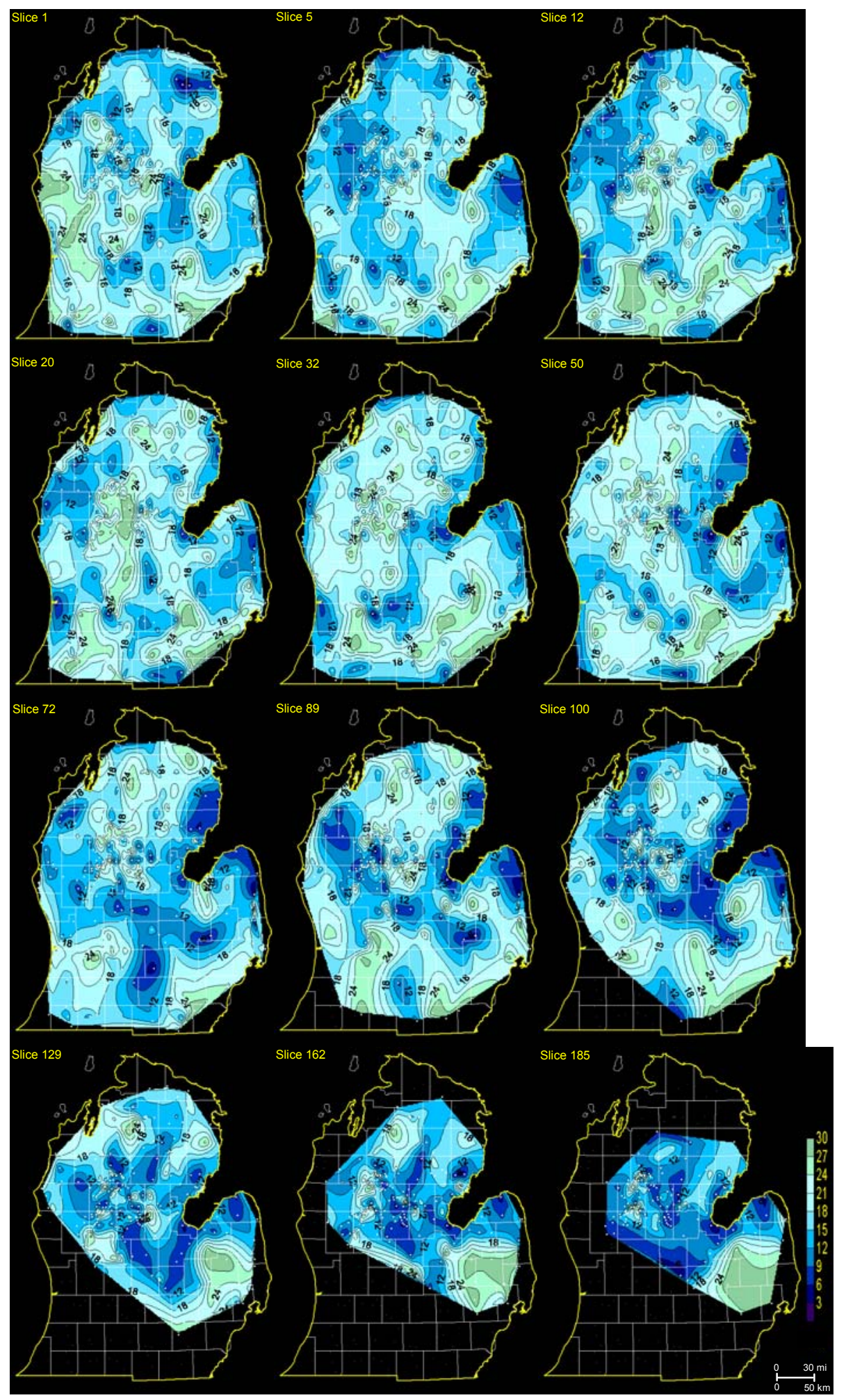




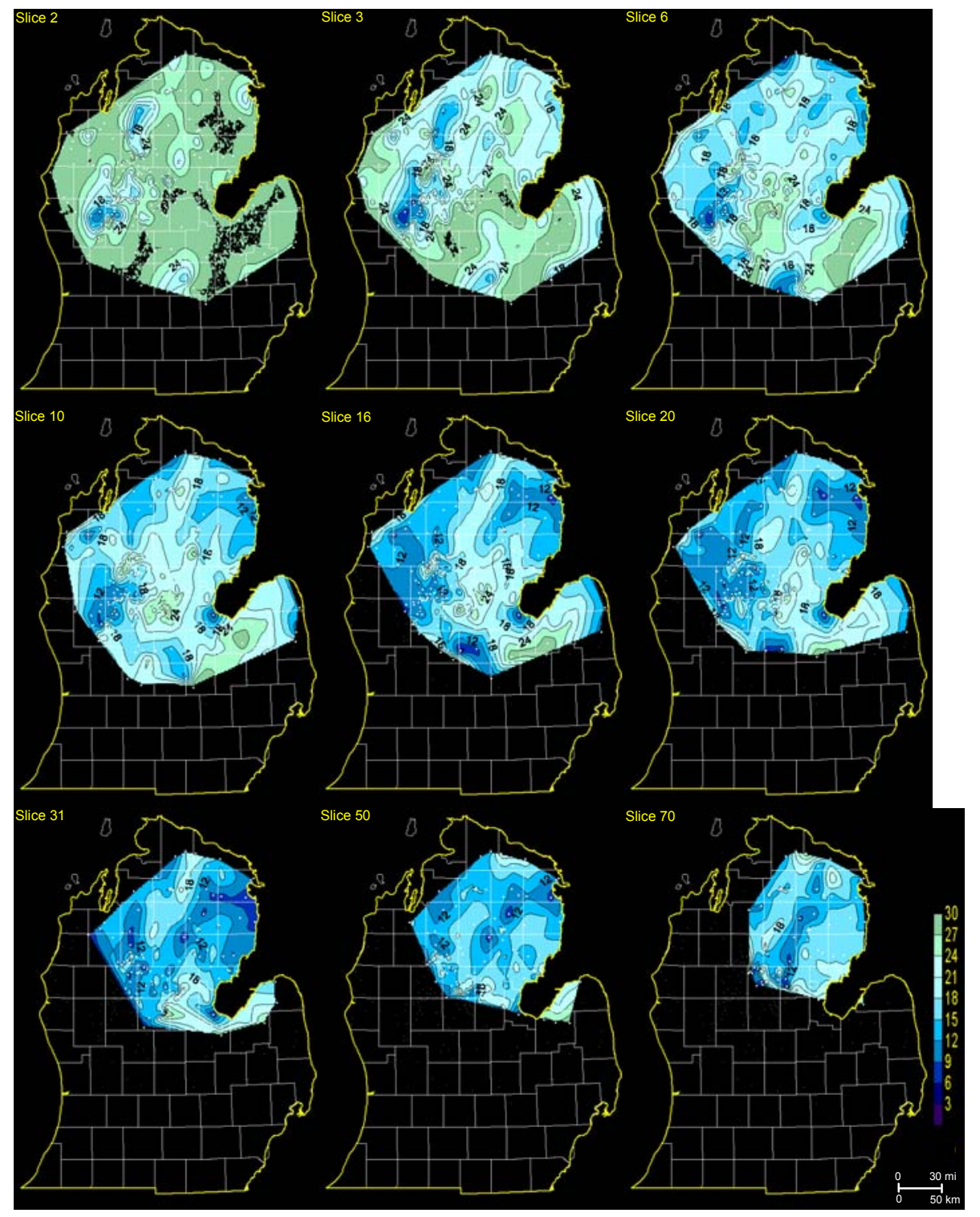

Figure 26. Representative top-down slices for the Rogers City Limestone. Slice numbers correspond to the depth (ft) beneath the Bell Shale-Rogers City Limestone contact. The contour interval is 3 APIU and the white dots represent the wells used for contouring. Note that the black color within the contoured area for Slices 2 and 3 is a product of the gridding algorithm and lies within the 27-30 APIU range. 


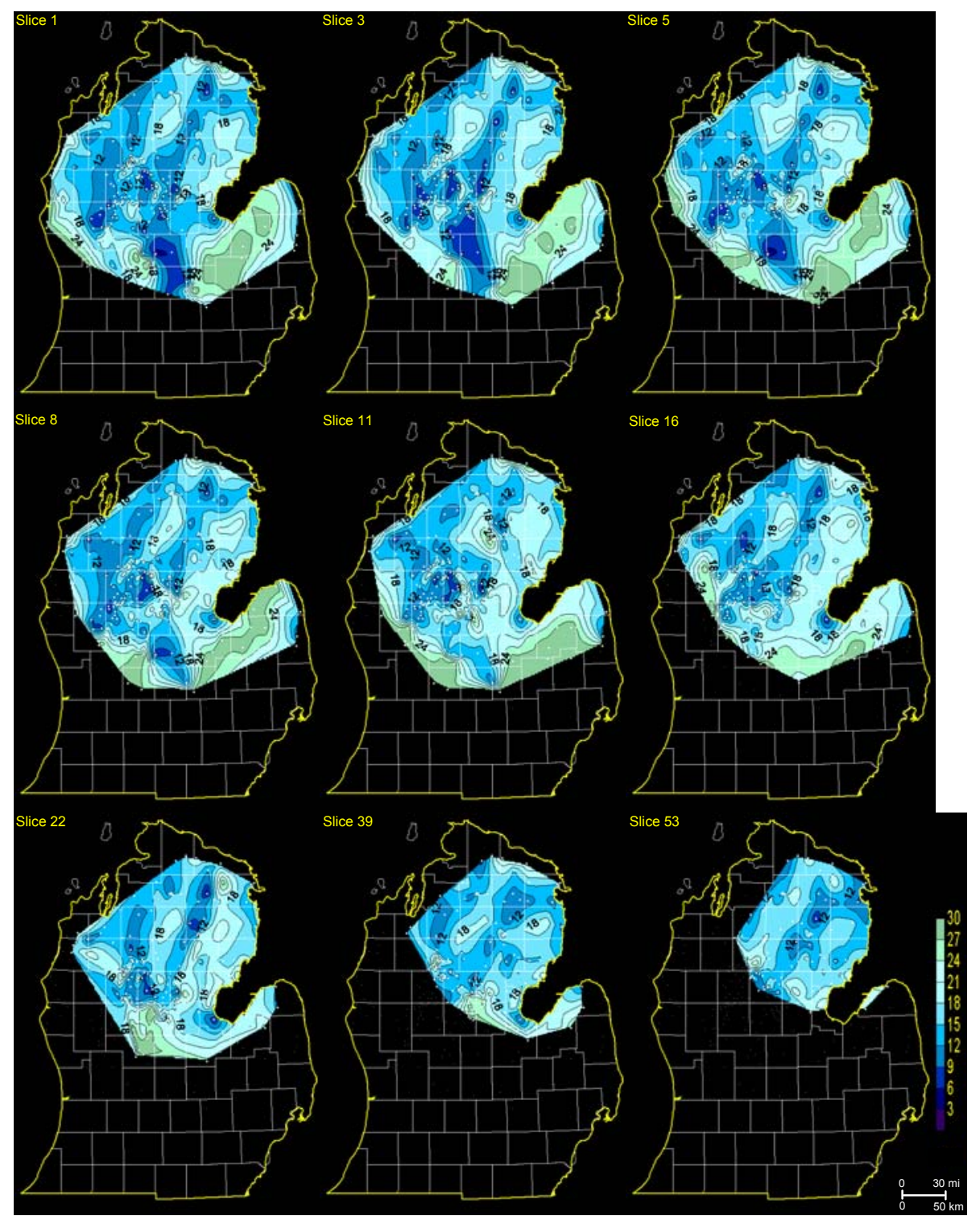

Figure 27. Representative bottom-up slices for the Rogers City Limestone. Slice numbers correspond to the depth (ft) above the Rogers City-Dundee contact. The contour interval is 3 APIU and the white dots represent the wells used for contouring. 


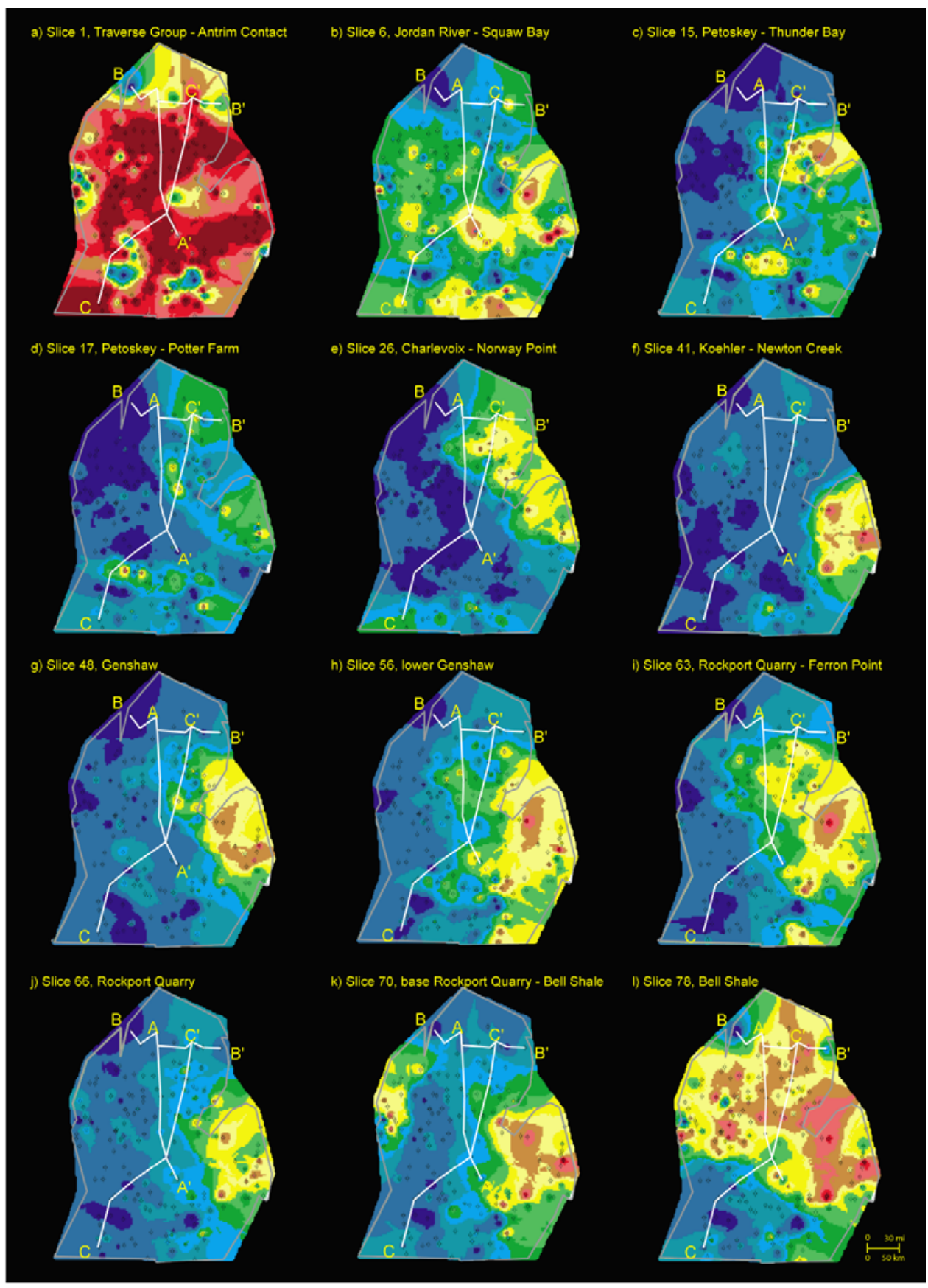

Figure 28. Twelve representative proportional slice images of the Traverse Group. The color contour scale is as follows: blue- less than 40 APIU, green and yellow- 40 to 80 APIU, brown and red- 80 to 150 APIU. The blue contours infer carbonate lithology, green-yellow contours infer mixed carbonate and shale (e.g. argillaceous limestone), and the brown-red contours infer shale or claystone (taken from Wylie, 2002). 


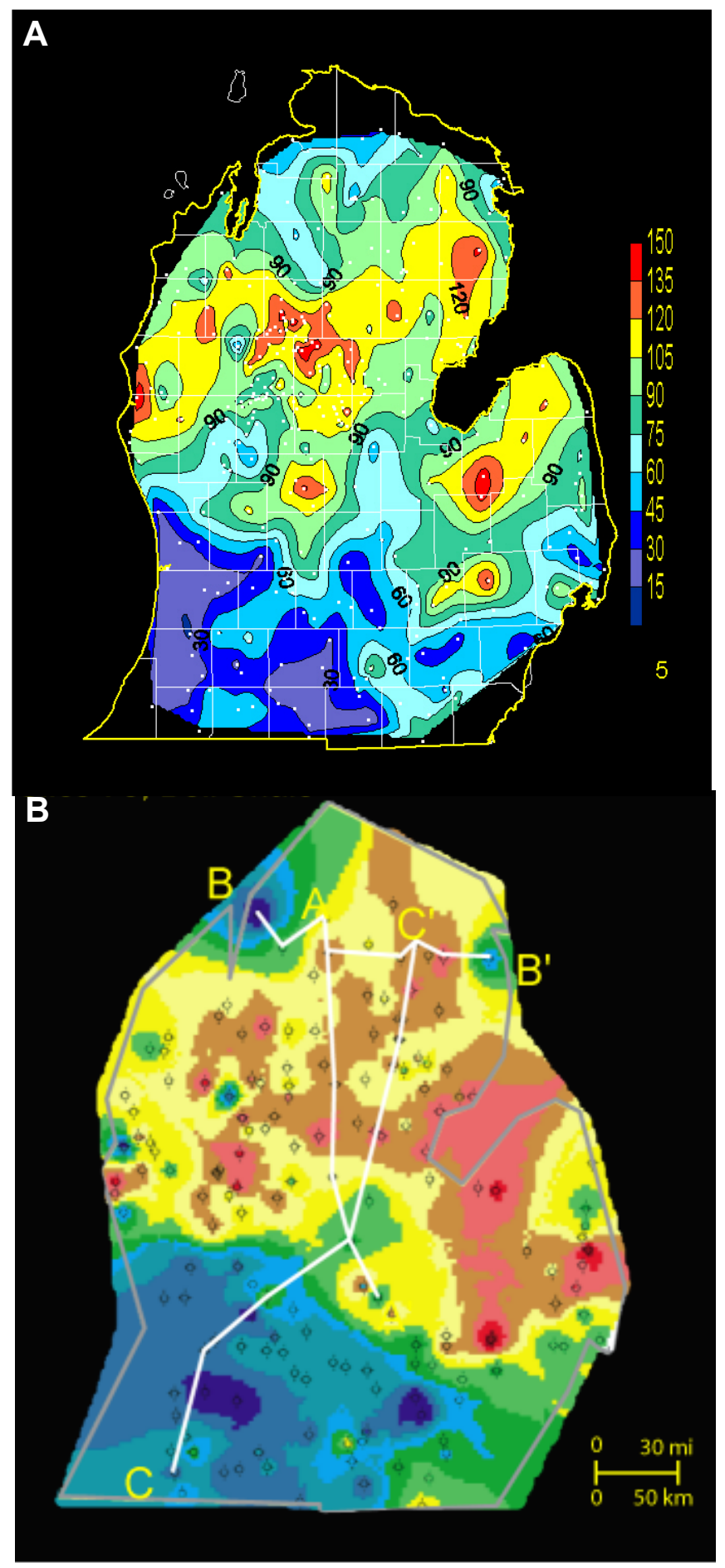

Figure 29. Comparison of the Bell Shale using the WLT and LCAS methods. (A) WLT slice image for $5 \mathrm{ft}$ above the base of the Bell Shale. (B) LCAS proportional slice image at the base of the Bell Shale (taken from Wylie, 2002). Note that the color contour scale refers only to the WLT slice (A). 


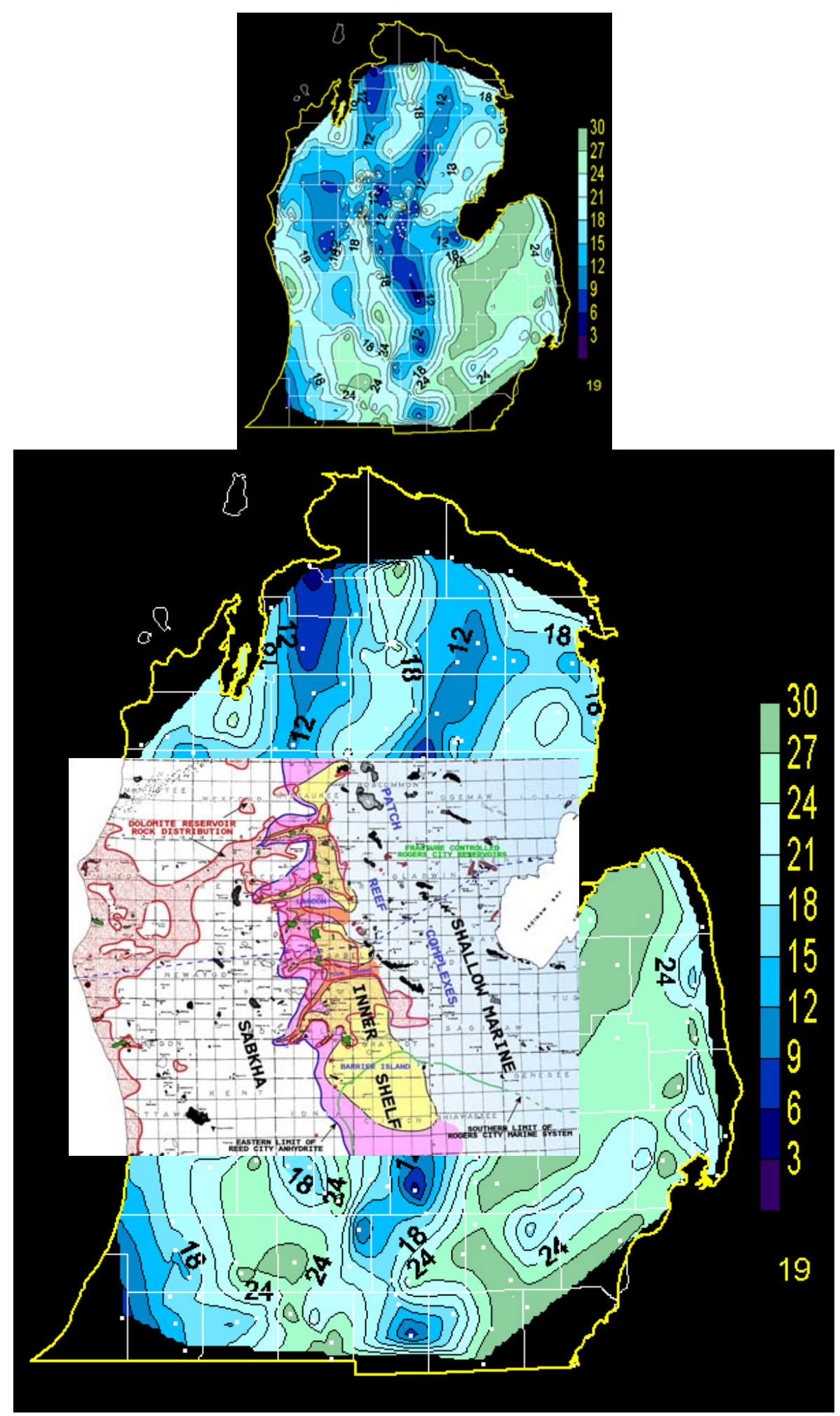

Figure 30. (A) Slice 19 from the top-down Dundee Limestone results. (B) Taylor's (2001) depositional model for the upper Dundee superimposed onto slice 19 illustrating the similarity between the shelf trend in Taylor's model and the low gamma ray trend from the slicing results. 


\section{Appendix A: Digital Log Information}

Description of the columns:

Permit- well permit number

Name- county name

Top picks,

$R G R C$ - Rogers City, $D N D E$ - Dundee, $D R R V$ - Detroit River, $D R B$ - Bentonite

Well Location,

Latitude, Longitude, Twn-township, Rng- range, Sec- section number

$K B$ - kelly bushing

$T D$ - total depth

(*) No TD available, used LAS file "stop depth" as proxy

Type-well type

D- dry hole, O- oil or oil/gas, G-gas, GC-gas condensate, GS- gas storage

BD-brine disposal well, WI-water injection well, OI-other injection well,

Obs-observation well.

Omit- provides reasons for excluding wells

1- well in a group or field was not chosen to be the "representative" well

2- no digitial gamma ray data for the Dundee- Rogers City interval

3- duplicate or triplicate well

4- digitizing error

5- outlier

6- other 
M. Le, MS Thesis, 2004

\begin{tabular}{|c|c|c|c|c|c|c|c|c|c|c|c|c|c|c|}
\hline Permit & Name & RGRC & DNDE & DRRV & DRB & Latitude & Longitude & Twn & Rng & Sec & KB & TD & Type & Omit \\
\hline 23208 & Alcona & 1596 & 1691 & 1856 & & 44.64125 & -83.33780 & $26 N$ & $9 \mathrm{E}$ & 22 & 733 & 2610 & D & 1 \\
\hline 24102 & Alcona & 1912 & 2012 & 2201 & & 44.68279 & -83.55712 & $26 \mathrm{~N}$ & $7 E$ & 2 & 877 & 2987 & $\mathrm{D}$ & 1 \\
\hline 34931 & Alcona & 2692 & 2792 & 2947 & 3132 & 44.60795 & -83.87002 & $26 \mathrm{~N}$ & $5 E$ & 31 & 987 & 10402 & $\mathrm{D}$ & 1 \\
\hline 32648 & Allegan & & 2045 & 2159 & 2234 & 42.69800 & -85.63505 & $4 \mathrm{~N}$ & $11 \mathrm{~W}$ & 29 & 772 & 4721 & $\mathrm{D}$ & 1 \\
\hline 32870 & Allegan & & 1993 & 2106 & 2181 & 42.63780 & -85.71407 & $3 \mathrm{~N}$ & $12 W$ & 22 & 739 & 4400 & $\mathrm{D}$ & 2 \\
\hline 34060 & Allegan & & 1892 & 1950 & 2078 & 42.65174 & -85.82360 & $3 \mathrm{~N}$ & $13 \mathrm{~W}$ & 15 & 882 & 3200 & $D$ & 1 \\
\hline 25690 & Alpena & 305 & 405 & 501 & & 45.11610 & -83.35227 & $31 \mathrm{~N}$ & $9 \mathrm{E}$ & 5 & 684 & 6380 & $\mathrm{D}$ & 1 \\
\hline 29513 & Alpena & 384 & 484 & 580 & & 45.09336 & -83.39298 & $31 \mathrm{~N}$ & $8 \mathrm{E}$ & 12 & 669 & 3900 & $\mathrm{D}$ & 1 \\
\hline 29571 & Alpena & 616 & 711 & 845 & & 45.11750 & -83.81702 & $32 \mathrm{~N}$ & $5 E$ & 34 & 756 & 5971 & $\mathrm{D}$ & 3 \\
\hline 37950 & Alpena & 1050 & 1150 & 1285 & & 44.90526 & -83.46694 & $29 N$ & $8 \mathrm{E}$ & 16 & 785 & 7120 & $\mathrm{D}$ & 1 \\
\hline 39200 & Alpena & 1409 & 1509 & 1634 & 1843 & 44.91831 & -83.83193 & $29 \mathrm{~N}$ & $5 E$ & 9 & 887 & 8500 & $\mathrm{G}$ & 1 \\
\hline 22639 & Antrim & & 1220 & 1368 & & 45.15630 & -85.33428 & $32 \mathrm{~N}$ & $8 W$ & 19 & 878 & 5778 & $\mathrm{D}$ & 1 \\
\hline 35702 & Antrim & 1746 & 1796 & 1936 & & 44.97258 & -85.13593 & $30 N$ & $7 \mathrm{~W}$ & 27 & 731 & 7322 & $\mathrm{D}$ & 2 \\
\hline 34973 & Arenac & 2936 & 3036 & 3383 & 3450 & 44.02771 & -83.86957 & $19 \mathrm{~N}$ & $5 E$ & 21 & 629 & 11425 & $D$ & 1 \\
\hline 39249 & Arenac & 2434 & 2534 & 2808 & 2940 & 44.15724 & -83.99120 & $20 N$ & $4 \mathrm{E}$ & 4 & 826 & 12100 & $G$ & 1 \\
\hline 39553 & Arenac & 2969 & 3094 & 3379 & & 44.11051 & -83.70986 & $20 N$ & $6 \mathrm{E}$ & 26 & 621 & 12087 & $\mathrm{G}$ & 1 \\
\hline 40097 & Arenac & 3289 & 3389 & 3687 & 3757 & 44.11156 & -83.60755 & $20 \mathrm{~N}$ & $7 E$ & 27 & 630 & 11920 & $\mathrm{D}$ & 1 \\
\hline 40763 & Arenac & 2918 & 3043 & 3322 & & 44.12363 & -83.73261 & $20 \mathrm{~N}$ & $6 \mathrm{E}$ & 22 & 630 & 11850 & $\mathrm{O}$ & 1 \\
\hline 42858 & Arenac & 2937 & 3037 & 3326 & & 44.06008 & -83.68134 & $19 \mathrm{~N}$ & $7 \mathrm{E}$ & 7 & 621 & 15514 & $\mathrm{O}$ & 3 \\
\hline 23572 & Barry & & 2444 & 2539 & 2643 & 42.72033 & -85.16498 & $4 \mathrm{~N}$ & $7 \mathrm{~W}$ & 20 & 882 & $5711^{*}$ & $D$ & 1 \\
\hline 24504 & Barry & & 2071 & 2181 & 2263 & 42.66664 & -85.42845 & $3 \mathrm{~N}$ & $10 \mathrm{~W}$ & 12 & 776 & $5004^{*}$ & $D$ & 1 \\
\hline 36965 & Barry & & 2311 & 2395 & 2490 & 42.64149 & -85.23349 & $3 \mathrm{~N}$ & $8 W$ & 15 & 945 & 5616 & $\mathrm{D}$ & 1 \\
\hline 39719 & Barry & & 2336 & 2425 & 2531 & 42.63317 & -85.10111 & $3 N$ & $7 \mathrm{~W}$ & 23 & 927 & 5530 & $\mathrm{D}$ & 1 \\
\hline 37779 & Bay & 2756 & 2806 & 3134 & 3204 & 43.63587 & -83.95252 & $14 \mathrm{~N}$ & $4 \mathrm{E}$ & 11 & 621 & 14589 & $\mathrm{GC}$ & 1 \\
\hline 39976 & Bay & & & & & 43.79479 & -83.98120 & $16 \mathrm{~N}$ & $4 \mathrm{E}$ & 15 & 633 & 12500 & $G$ & \\
\hline 40516 & Bay & 3065 & 3140 & 3465 & 3544 & 43.79823 & -84.03292 & $16 \mathrm{~N}$ & $4 \mathrm{E}$ & 7 & 644 & 12430 & $\mathrm{GC}$ & 1 \\
\hline 41133 & Bay & 3043 & 3138 & 3436 & 3556 & 43.94507 & -84.14046 & $18 \mathrm{~N}$ & $3 E$ & 20 & 782 & 12770 & $\mathrm{G}$ & 6 \\
\hline 29711 & Benzie & 1578 & 1593 & 1725 & & 44.53619 & -86.14207 & $25 \mathrm{~N}$ & $15 W$ & 29 & 707 & 4328 & $\mathrm{D}$ & 1 \\
\hline 31855 & Benzie & 1977 & 2002 & 2128 & & 44.57281 & -85.97692 & $25 \mathrm{~N}$ & $14 W$ & 11 & 812 & $3250^{*}$ & $\mathrm{D}$ & 3 \\
\hline 37007 & Benzie & & & & & 44.53944 & -85.84039 & $25 \mathrm{~N}$ & $13 W$ & 26 & 903 & 5670 & $\mathrm{D}$ & \\
\hline 26112 & Berrien & & 886 & 965 & & 41.95775 & -86.26294 & $6 S$ & $17 \mathrm{~W}$ & 10 & 804 & 5648 & $\mathrm{D}$ & 1 \\
\hline 29779 & Branch & & 1334 & 1369 & & 42.05506 & -85.28130 & $5 S$ & $8 W$ & 7 & 890 & 5432 & $\mathrm{D}$ & 1 \\
\hline
\end{tabular}


M. Le, MS Thesis, 2004

\begin{tabular}{|c|c|c|c|c|c|c|c|c|c|c|c|c|c|c|}
\hline Permit & Name & RGRC & DNDE & DRRV & DRB & Latitude & Longitude & Twn & Rng & Sec & KB & TD & Type & Omit \\
\hline 33019 & Branch & & 1120 & 1149 & 1187 & 41.77103 & -84.96022 & $8 S$ & $6 W$ & 13 & 1019 & 4633 & $D$ & 1 \\
\hline 37569 & Branch & & 1238 & 1269 & & 41.97126 & -85.21600 & $6 S$ & $8 W$ & 3 & 911 & $5248^{*}$ & $\mathrm{D}$ & 1 \\
\hline 38045 & Branch & & 1289 & 1319 & 1383 & 41.94235 & -85.07792 & $6 S$ & $7 \mathrm{~W}$ & 13 & 944 & 5378 & $\mathrm{D}$ & 1 \\
\hline 38169 & Branch & & 1135 & 1163 & 1216 & 41.84277 & -84.95950 & $7 S$ & $6 W$ & 24 & 1011 & 3473 & $\mathrm{D}$ & 2 \\
\hline 22352 & Calhoun & & 1658 & 1702 & 1786 & 42.20369 & -85.19459 & $3 S$ & $8 W$ & 13 & 952 & 4739 & $\mathrm{D}$ & \\
\hline 34619 & Calhoun & & 1657 & 1699 & 1740 & 42.18952 & -84.85558 & $3 S$ & $5 W$ & 33 & 982 & 4315 & $\mathrm{D}$ & 2 \\
\hline 34783 & Calhoun & & 2016 & 2126 & 2196 & 42.35149 & -84.78869 & $1 \mathrm{~S}$ & $4 W$ & 28 & 939 & $3400^{*}$ & $\mathrm{D}$ & 1 \\
\hline 34763 & Cass & & 1176 & 1258 & 1313 & 42.05323 & -85.96071 & $5 S$ & $14 W$ & 8 & 885 & 4000 & $\mathrm{D}$ & 2 \\
\hline 35459 & Cass & & 881 & 966 & & 41.81015 & -85.86569 & $7 S$ & $13 \mathrm{~W}$ & 31 & 897 & 3800 & $\mathrm{D}$ & 1 \\
\hline 35553 & Cass & & 1062 & 1146 & & 41.93047 & -85.92542 & $6 S$ & $14 W$ & 22 & 890 & 3238 & $\mathrm{D}$ & 1 \\
\hline 37536 & Cass & & 1248 & 1338 & 1391 & 42.05131 & -85.78565 & $5 S$ & $13 \mathrm{~W}$ & 11 & 895 & 3900 & $\mathrm{D}$ & 3 \\
\hline 23435 & Charlevoix & & & & & 45.65858 & -85.52788 & $38 \mathrm{~N}$ & $10 W$ & 27 & 678 & 5383 & $\mathrm{D}$ & 2 \\
\hline 29079 & Charlevoix & & 641 & 717 & & 45.34931 & -85.09757 & $34 \mathrm{~N}$ & $7 \mathrm{~W}$ & 13 & 743 & 5022 & $\mathrm{D}$ & 3 \\
\hline 34824 & Charlevoix & & & & & 45.14005 & -84.79456 & $32 \mathrm{~N}$ & $4 W$ & 27 & 1145 & 8900 & $\mathrm{D}$ & \\
\hline 36260 & Charlevoix & 1586 & 1626 & 1804 & & 45.12470 & -84.81299 & $32 \mathrm{~N}$ & $4 W$ & 33 & 1195 & 8030 & $\mathrm{D}$ & 1 \\
\hline 30682 & Cheboygan & 221 & 296 & 364 & & 45.40920 & -84.37300 & $35 \mathrm{~N}$ & $1 \mathrm{~W}$ & 24 & 801 & 5753 & $\mathrm{D}$ & 1 \\
\hline 35060 & Cheboygan & 397 & 467 & 600 & & 45.35375 & -84.52022 & $34 \mathrm{~N}$ & $2 W$ & 11 & 813 & 5940 & $\mathrm{D}$ & 2 \\
\hline 22435 & Clare & & & & & 44.11176 & -84.80796 & $20 N$ & $4 W$ & 21 & 1219 & 5456 & $\mathrm{D}$ & 1 \\
\hline 25847 & Clare & & & & & 44.14222 & -84.92978 & $20 N$ & $5 W$ & 8 & 1118 & 3819 & $\mathrm{D}$ & 1 \\
\hline 26649 & Clare & & & & & 44.02090 & -85.03729 & $19 \mathrm{~N}$ & $6 W$ & 21 & 1055 & 4000 & $\mathrm{D}$ & 1 \\
\hline 27451 & Clare & & & & & 44.09006 & -85.07905 & $20 N$ & $6 W$ & 30 & 1146 & 5155 & $\mathrm{O}$ & 1 \\
\hline 27530 & Clare & & & & & 44.08620 & -85.07924 & $20 N$ & $6 W$ & 31 & 1129 & 5057 & $\mathrm{O}$ & 1 \\
\hline 27575 & Clare & & & & & 44.09305 & -85.07933 & $20 N$ & $6 W$ & 30 & 1154 & 5213 & $\mathrm{O}$ & 1 \\
\hline 29087 & Clare & & & & & 44.06211 & -84.72463 & $19 \mathrm{~N}$ & $3 W$ & 6 & 1133 & 5265 & $\mathrm{O}$ & 1 \\
\hline 29136 & Clare & & & & & 44.02824 & -84.98524 & $19 \mathrm{~N}$ & $6 W$ & 24 & 1135 & 4056 & $\mathrm{D}$ & 1 \\
\hline 30563 & Clare & & & & & 44.00947 & -84.62026 & $19 \mathrm{~N}$ & $3 W$ & 25 & 944 & 5250 & $\mathrm{D}$ & 1 \\
\hline 30745 & Clare & & & & & 44.13869 & -84.93985 & $20 N$ & $5 W$ & 8 & 1117 & 5153 & $\mathrm{O}$ & 1 \\
\hline 31186 & Clare & & & & & 44.09967 & -85.06427 & $20 N$ & $6 W$ & 29 & 1133 & 5122 & $\mathrm{O}$ & 1 \\
\hline 31596 & Clare & & & & & 44.09700 & -85.06949 & $20 N$ & $6 W$ & 30 & 1144 & 5150 & $\mathrm{O}$ & 1 \\
\hline 31654 & Clare & & & & & 44.14632 & -84.98755 & $20 N$ & $6 W$ & 12 & 1151 & 5207 & 0 & 2 \\
\hline 31697 & Clare & & & & & 44.09393 & -85.07028 & $20 N$ & $6 W$ & 30 & 1145 & 5120 & $\mathrm{WI}$ & 4 \\
\hline 31698 & Clare & & & & & 44.09719 & -85.06445 & $20 N$ & $6 W$ & 29 & 1135 & 5119 & WI & 2 \\
\hline
\end{tabular}


M. Le, MS Thesis, 2004

\begin{tabular}{|c|c|c|c|c|c|c|c|c|c|c|c|c|c|c|}
\hline Permit & Name & RGRC & DNDE & DRRV & DRB & Latitude & Longitude & Twn & Rng & Sec & KB & TD & Type & Omit \\
\hline 32227 & Clare & & & & & 44.09717 & -85.06026 & $20 \mathrm{~N}$ & $6 W$ & 29 & 1144 & 5150 & 0 & 2 \\
\hline 32296 & Clare & & & & & 44.10072 & -85.06007 & $20 N$ & $6 W$ & 29 & 1149 & 5181 & WI & 2 \\
\hline 32297 & Clare & & & & & 44.10059 & -85.07003 & $20 \mathrm{~N}$ & $6 W$ & 30 & 1144 & 5150 & WI & 2 \\
\hline 32372 & Clare & & & & & 44.10079 & -85.07418 & $20 N$ & $6 W$ & 30 & 1152 & 5176 & $\mathrm{O}$ & 2 \\
\hline 32384 & Clare & & & & & 44.09733 & -85.05449 & $20 N$ & $6 W$ & 29 & 1122 & 5148 & WI & 2 \\
\hline 32385 & Clare & & & & & 44.09726 & -85.07423 & $20 N$ & $6 W$ & 30 & 1156 & 5183 & $\mathrm{WI}$ & 2 \\
\hline 32392 & Clare & & & & & 44.09670 & -85.07918 & $20 N$ & $6 W$ & 30 & 1160 & 5180 & $\mathrm{O}$ & 2 \\
\hline 32393 & Clare & & & & & 44.09670 & -85.08452 & $20 N$ & $6 W$ & 30 & 1156 & 5170 & $\mathrm{O}$ & 2 \\
\hline 32396 & Clare & & & & & 44.10054 & -85.05449 & $20 N$ & $6 W$ & 29 & 1129 & 5170 & $\mathrm{O}$ & 2 \\
\hline 32398 & Clare & & & & & 44.09385 & -85.05950 & $20 N$ & $6 W$ & 29 & 1123 & 5134 & $\mathrm{WI}$ & 2 \\
\hline 32461 & Clare & & & & & 44.07210 & -84.97083 & $19 \mathrm{~N}$ & $6 W$ & 1 & 1107 & 5190 & $\mathrm{D}$ & 2 \\
\hline 32477 & Clare & & & & & 44.09319 & -85.06481 & $20 N$ & $6 W$ & 29 & 1135 & 5140 & $\mathrm{O}$ & 2 \\
\hline 32546 & Clare & 3983 & 4033 & 4227 & 4442 & 43.87926 & -84.70439 & $17 \mathrm{~N}$ & $3 W$ & 8 & 940 & 5315 & $\mathrm{D}$ & 1 \\
\hline 32858 & Clare & & & & & 43.94164 & -84.93598 & $18 \mathrm{~N}$ & $5 W$ & 20 & 1144 & 5340 & $\mathrm{O}$ & 2 \\
\hline 32880 & Clare & & & & & 44.08624 & -85.06961 & $20 N$ & $6 W$ & 31 & 1119 & 5115 & WI & 2 \\
\hline 32890 & Clare & & & & & 44.08653 & -85.07436 & $20 N$ & $6 W$ & 31 & 1137 & 5132 & $\mathrm{O}$ & 2 \\
\hline 32897 & Clare & & & & & 44.08663 & -85.05465 & $20 \mathrm{~N}$ & $6 W$ & 32 & 1101 & 5161 & $\mathrm{D}$ & 2 \\
\hline 32902 & Clare & & & & & 44.09333 & -85.07420 & $20 N$ & $6 W$ & 30 & 1114 & 5150 & $\mathrm{O}$ & 2 \\
\hline 32930 & Clare & 4143 & 4218 & 4430 & 4637 & 43.96126 & -84.86586 & $18 \mathrm{~N}$ & $5 W$ & 12 & 1237 & 5560 & $\mathrm{D}$ & 3 \\
\hline 32966 & Clare & & & & & 44.08600 & -85.06504 & $20 N$ & $6 W$ & 32 & 1132 & 5150 & $\mathrm{O}$ & 2 \\
\hline 32971 & Clare & & & & & 44.08319 & -85.06466 & $20 N$ & $6 W$ & 32 & 1107 & 5115 & WI & 2 \\
\hline 32991 & Clare & & & & & 44.09060 & -85.06114 & $20 N$ & $6 W$ & 29 & 1118 & 5132 & $\mathrm{O}$ & 2 \\
\hline 32992 & Clare & & & & & 44.08256 & -85.06965 & $20 N$ & $6 W$ & 31 & 1136 & 5141 & $\mathrm{O}$ & 2 \\
\hline 33004 & Clare & & & & & 44.08278 & -85.06025 & $20 N$ & $6 W$ & 32 & 1096 & 5100 & $\mathrm{G}$ & 2 \\
\hline 33011 & Clare & 3738 & 3813 & 4004 & 4220 & 44.08343 & -85.07440 & $20 N$ & $6 W$ & 31 & 1132 & 5125 & $\mathrm{WI}$ & 2 \\
\hline 33097 & Clare & & & & & 43.88554 & -84.83747 & $17 \mathrm{~N}$ & $4 \mathrm{~W}$ & 7 & 993 & 5250 & $D$ & 2 \\
\hline 33467 & Clare & & & & & 44.08970 & -85.07420 & $20 \mathrm{~N}$ & $6 W$ & 30 & 1142 & 5137 & WI & 2 \\
\hline 33492 & Clare & & & & & 44.09643 & -85.06569 & $20 N$ & $6 W$ & 29 & 1149 & 4082 & $B D$ & 2 \\
\hline 33508 & Clare & 3773 & 3848 & 4054 & 4279 & 44.14768 & -84.99169 & $20 N$ & $6 W$ & 2 & 1128 & 5251 & $\mathrm{O}$ & 1 \\
\hline 33526 & Clare & 3971 & 4046 & 4244 & 4467 & 43.95167 & -84.95145 & $18 \mathrm{~N}$ & $5 W$ & 18 & 1129 & 5320 & $\mathrm{O}$ & 1 \\
\hline 33609 & Clare & & & & & 44.08960 & -85.08450 & $20 N$ & $6 W$ & 30 & 1137 & 5155 & $\mathrm{WI}$ & 2 \\
\hline 33633 & Clare & & & & & 44.08258 & -85.07924 & $20 N$ & $6 W$ & 31 & 1140 & 5140 & $\mathrm{O}$ & 2 \\
\hline
\end{tabular}


M. Le, MS Thesis, 2004

\begin{tabular}{|c|c|c|c|c|c|c|c|c|c|c|c|c|c|c|}
\hline Permit & Name & RGRC & DNDE & DRRV & DRB & Latitude & Longitude & Twn & Rng & Sec & $\mathrm{KB}$ & TD & Type & Omit \\
\hline 33680 & Clare & & & & & 44.09751 & -85.07990 & $20 \mathrm{~N}$ & $6 W$ & 30 & 1158 & 10260 & $G$ & 2 \\
\hline 33723 & Clare & & & & & 44.10393 & -85.06439 & $20 N$ & $6 W$ & 20 & 1145 & 5175 & $\mathrm{WI}$ & 2 \\
\hline 34326 & Clare & 4194 & 4269 & 4482 & 4692 & 43.99644 & -84.87657 & $19 \mathrm{~N}$ & $5 W$ & 35 & 1239 & 5600 & $\mathrm{D}$ & 1 \\
\hline 34330 & Clare & 3933 & 4008 & 4205 & 4433 & 44.05852 & -84.70893 & $19 \mathrm{~N}$ & $3 W$ & 7 & 1092 & 5335 & $\mathrm{BD}$ & 1 \\
\hline 34331 & Clare & & & & & 44.06538 & -84.71941 & $19 \mathrm{~N}$ & $3 W$ & 6 & 1162 & 5373 & $\mathrm{O}$ & 2 \\
\hline 34370 & Clare & & & & & 44.10435 & -85.05952 & $20 N$ & $6 W$ & 20 & 1151 & 5170 & $\mathrm{O}$ & 2 \\
\hline 34493 & Clare & 3810 & 3885 & 4087 & 4296 & 44.10411 & -85.05435 & $20 N$ & $6 W$ & 20 & 1116 & 5145 & $\mathrm{D}$ & 1 \\
\hline 34611 & Clare & 3920 & 3970 & 4179 & 4386 & 43.88485 & -84.82961 & $17 \mathrm{~N}$ & $4 \mathrm{~W}$ & 7 & 1004 & 11864 & $\mathrm{D}$ & 2 \\
\hline 34662 & Clare & & & & & 44.14230 & -84.94995 & $20 N$ & $5 W$ & 7 & 1106 & 5190 & $\mathrm{O}$ & 2 \\
\hline 34698 & Clare & & & & & 44.14572 & -84.96603 & $20 N$ & $5 W$ & 7 & 1137 & 5200 & $\mathrm{O}$ & \\
\hline 34706 & Clare & & & & & 44.14237 & -84.96520 & $20 N$ & $5 W$ & 7 & 1127 & 5190 & $\mathrm{O}$ & \\
\hline 34710 & Clare & 4198 & 4273 & 4466 & & 43.99021 & -84.81420 & $19 \mathrm{~N}$ & $4 W$ & 32 & 1194 & 4538 & $\mathrm{D}$ & 1 \\
\hline 34790 & Clare & 4003 & 4053 & 4234 & 4415 & 43.82184 & -85.02634 & $17 \mathrm{~N}$ & $6 W$ & 34 & 1121 & 13022 & $D$ & 1 \\
\hline 34790 & Clare & & & & & 43.82184 & -85.02634 & $17 \mathrm{~N}$ & $6 W$ & 34 & 1121 & 13022 & $\mathrm{D}$ & \\
\hline 34790 & Clare & & & & & 43.82184 & -85.02634 & $17 \mathrm{~N}$ & $6 W$ & 34 & 1121 & 13022 & $\mathrm{D}$ & \\
\hline 35649 & Clare & & & & & 44.07550 & -84.89575 & $20 N$ & $5 W$ & 34 & 1138 & 5365 & $\mathrm{D}$ & \\
\hline 35652 & Clare & & & & & 44.13152 & -84.94519 & $20 \mathrm{~N}$ & $5 W$ & 17 & 1104 & 5180 & $\mathrm{D}$ & \\
\hline 35690 & Clare & & & & & 43.86300 & -85.08488 & $17 \mathrm{~N}$ & $6 W$ & 18 & 1059 & 5155 & $\mathrm{O}$ & \\
\hline 35762 & Clare & 3768 & 3843 & 4036 & 4262 & 44.13443 & -84.93985 & $20 N$ & $5 W$ & 8 & 1109 & 5205 & $\mathrm{O}$ & 1 \\
\hline 35781 & Clare & & & & & 44.11060 & -85.07683 & $20 N$ & $6 W$ & 19 & 1166 & 11563 & $\mathrm{D}$ & \\
\hline 35781 & Clare & & & & & 44.11060 & -85.07683 & $20 N$ & $6 W$ & 19 & 1166 & 11563 & $\mathrm{D}$ & \\
\hline 35963 & Clare & 3811 & 3886 & 4080 & 4303 & 44.08940 & -84.61060 & $20 N$ & $3 W$ & 36 & 997 & 5215 & WI & 1 \\
\hline 36333 & Clare & & & & & 44.10831 & -85.06442 & $20 N$ & $6 W$ & 20 & 1131 & 5131 & $\mathrm{O}$ & \\
\hline 36565 & Clare & & & & & 44.07896 & -85.06969 & $20 \mathrm{~N}$ & $6 \mathrm{~W}$ & 31 & 1117 & 5121 & $\mathrm{WI}$ & \\
\hline 36751 & Clare & & & & & 44.08287 & -85.04465 & $20 N$ & $6 W$ & 33 & 1095 & 5190 & 0 & \\
\hline 37423 & Clare & & & & & 44.08664 & -85.04216 & $20 N$ & $6 W$ & 33 & 1092 & 3875 & $B D$ & \\
\hline 37480 & Clare & & & & & 44.07507 & -85.07032 & $20 \mathrm{~N}$ & $6 \mathrm{~W}$ & 31 & 1112 & 5125 & $\mathrm{O}$ & \\
\hline 37659 & Clare & & & & & 43.86625 & -84.83679 & $17 \mathrm{~N}$ & $4 W$ & 18 & 943 & 5200 & $\mathrm{D}$ & \\
\hline 37709 & Clare & & & & & 44.07234 & -85.03481 & $19 \mathrm{~N}$ & $6 W$ & 4 & 1077 & 5143 & $\mathrm{D}$ & \\
\hline 37719 & Clare & & & & & 44.07133 & -85.07432 & $19 \mathrm{~N}$ & $6 W$ & 6 & 1105 & 3165 & $\mathrm{O}$ & \\
\hline 38434 & Clare & 3748 & 3798 & 4002 & 4198 & 43.81767 & -84.71900 & $17 \mathrm{~N}$ & $3 W$ & 31 & 836 & 4985 & $\mathrm{D}$ & 1 \\
\hline 38568 & Clare & 4053 & 4128 & 4307 & 4534 & 43.93163 & -84.66824 & $18 \mathrm{~N}$ & $3 W$ & 21 & 869 & 5200 & $\mathrm{D}$ & 1 \\
\hline
\end{tabular}


M. Le, MS Thesis, 2004

\begin{tabular}{|c|c|c|c|c|c|c|c|c|c|c|c|c|c|c|}
\hline Permit & Name & RGRC & DNDE & DRRV & DRB & Latitude & Longitude & Twn & Rng & Sec & $\mathrm{KB}$ & TD & Type & Omit \\
\hline 38760 & Clare & 3823 & 3898 & 4085 & 4303 & 44.11313 & -84.89254 & $20 \mathrm{~N}$ & $5 W$ & 22 & 1111 & 5216 & D & 2 \\
\hline 38982 & Clare & 3765 & 3840 & 4036 & 4248 & 44.08326 & -85.02030 & $20 N$ & $6 W$ & 34 & 1083 & 5155 & $\mathrm{D}$ & 1 \\
\hline 39007 & Clare & & & & & 44.09030 & -85.06203 & $20 \mathrm{~N}$ & $6 W$ & 29 & 1137 & 5140 & WI & \\
\hline 39127 & Clare & & & & & 44.07871 & -85.07471 & $20 N$ & $6 W$ & 31 & 1123 & 5110 & $\mathrm{O}$ & \\
\hline 39132 & Clare & & & & & 44.07988 & -85.07922 & $20 N$ & $6 W$ & 31 & 1132 & 5145 & WI & \\
\hline 39155 & Clare & & & & & 43.93895 & -84.87146 & $18 \mathrm{~N}$ & $5 W$ & 23 & 1159 & 4200 & $\mathrm{D}$ & \\
\hline 39165 & Clare & 3794 & 3869 & 4063 & & 44.02042 & -84.63777 & $19 \mathrm{~N}$ & $3 W$ & 23 & 950 & 4137 & $\mathrm{D}$ & 1 \\
\hline 40577 & Clare & & & & & 44.12333 & -84.95552 & $20 N$ & $5 W$ & 18 & 1125 & 11880 & $\mathrm{G}$ & \\
\hline 40987 & Clare & & & & & 44.07681 & -85.08002 & $20 N$ & $6 W$ & 31 & 1120 & 11540 & $\mathrm{G}$ & \\
\hline 40993 & Clare & & & & & 44.14185 & -84.98266 & $20 N$ & $6 W$ & 12 & 1167 & 12300 & $\mathrm{G}$ & \\
\hline 41464 & Clare & & & & & 44.14881 & -84.97326 & $20 N$ & $6 W$ & 1 & 1138 & 12997 & $\mathrm{G}$ & \\
\hline 41826 & Clare & & & & & 44.11229 & -85.08222 & $20 N$ & $6 W$ & 19 & 1167 & 11560 & $\mathrm{G}$ & \\
\hline 41826 & Clare & & & & & 44.11229 & -85.08222 & $20 \mathrm{~N}$ & $6 W$ & 19 & 1167 & 11560 & $\mathrm{G}$ & \\
\hline 22348 & Clinton & 2783 & 2788 & 2862 & 2998 & 42.82157 & -84.64042 & $5 \mathrm{~N}$ & $3 W$ & 14 & 834 & 5178 & $\mathrm{D}$ & \\
\hline 27811 & Clinton & & 2808 & 3015 & 3071 & 43.01606 & -84.47844 & $7 N$ & $1 \mathrm{~W}$ & 6 & 770 & 7781 & $\mathrm{D}$ & 3 \\
\hline 28862 & Crawford & 3145 & 3245 & 3441 & & 44.61242 & -84.62675 & $26 \mathrm{~N}$ & $3 W$ & 36 & 1242 & 8300 & $\mathrm{D}$ & 1 \\
\hline 35587 & Crawford & & & & & 44.59664 & -84.69215 & $25 N$ & $3 W$ & 5 & 1277 & 10447 & $\mathrm{O}$ & \\
\hline 41307 & Crawford & 2780 & 2880 & 3044 & & 44.69907 & -84.44543 & $27 N$ & $1 \mathrm{~W}$ & 28 & 1145 & 10760 & $G$ & 2 \\
\hline 43116 & Crawford & & & & & 44.84607 & -84.66506 & $28 \mathrm{~N}$ & $3 W$ & 3 & 1367 & 2396 & $\mathrm{G}$ & \\
\hline 28163 & Eaton & & 2159 & 2224 & 2337 & 42.47940 & -84.92133 & $1 \mathrm{~N}$ & $5 W$ & 17 & 883 & 5174 & $D$ & 1 \\
\hline 29117 & Eaton & & 2390 & 2443 & & 42.55114 & -84.61575 & $2 \mathrm{~N}$ & $3 W$ & 24 & 869 & 6922 & $\mathrm{D}$ & 1 \\
\hline 33604 & Eaton & & 2202 & 2273 & 2376 & 42.51667 & -85.00749 & $2 \mathrm{~N}$ & $6 W$ & 34 & 958 & 5341 & $\mathrm{D}$ & 1 \\
\hline 36319 & Eaton & & 2477 & 2547 & 2675 & 42.57687 & -84.71253 & $2 \mathrm{~N}$ & $3 W$ & 7 & 923 & 6051 & $\mathrm{D}$ & 1 \\
\hline 41423 & Eaton & & 2601 & 2694 & 2816 & 42.75361 & -84.91988 & $4 \mathrm{~N}$ & $5 W$ & 8 & 881 & 6770 & $D$ & 1 \\
\hline 28212 & Emmet & & & & & 45.55899 & -84.76258 & $37 N$ & $4 W$ & 35 & 714 & 3945 & D & 1 \\
\hline 23948 & Genesee & 2115 & 2120 & 2318 & 2337 & 42.89878 & -83.66838 & $6 \mathrm{~N}$ & $7 \mathrm{E}$ & 29 & 850 & 5537 & $\mathrm{D}$ & 1 \\
\hline 24028 & Genesee & 2148 & 2153 & 2334 & 2337 & 42.94361 & -83.47196 & $6 \mathrm{~N}$ & $8 \mathrm{E}$ & 12 & 915 & 5424 & $D$ & 1 \\
\hline 24079 & Genesee & 2459 & 2474 & 2691 & 2713 & 43.21128 & -83.53653 & $9 N$ & $8 E$ & 4 & 837 & 8525 & $\mathrm{D}$ & 4 \\
\hline 20493 & Gladwin & & & & & 43.96563 & -84.52658 & $18 \mathrm{~N}$ & $2 W$ & 10 & 845 & 5066 & $\mathrm{O}$ & 1 \\
\hline 20714 & Gladwin & & & & & 43.97983 & -84.54638 & $18 \mathrm{~N}$ & $2 W$ & 4 & 850 & 5678 & $D$ & 2 \\
\hline 24030 & Gladwin & & & & & 43.84835 & -84.59209 & $17 \mathrm{~N}$ & $2 W$ & 19 & 756 & 5093 & $\mathrm{D}$ & 1 \\
\hline 34805 & Gladwin & 3845 & 3895 & 4134 & 4327 & 43.87061 & -84.49291 & $17 \mathrm{~N}$ & $2 W$ & 13 & 740 & 5135 & $\mathrm{O}$ & 1 \\
\hline
\end{tabular}


M. Le, MS Thesis, 2004

\begin{tabular}{|c|c|c|c|c|c|c|c|c|c|c|c|c|c|c|}
\hline Permit & Name & RGRC & DNDE & DRRV & DRB & Latitude & Longitude & Twn & Rng & Sec & KB & TD & Type & Omit \\
\hline 35090 & Gladwin & 3598 & 3673 & 3966 & 4098 & 43.88525 & -84.33464 & $17 N$ & $1 \mathrm{E}$ & 15 & 735 & 15859 & D & 1 \\
\hline 35846 & Gladwin & 3886 & 3936 & 4192 & 4384 & 43.89994 & -84.59358 & $17 N$ & $2 W$ & 6 & 778 & 5175 & $\mathrm{D}$ & 1 \\
\hline 37774 & Gladwin & 3798 & 3848 & 4070 & 4260 & 43.82445 & -84.50479 & $17 \mathrm{~N}$ & $2 W$ & 36 & 748 & 5075 & $\mathrm{D}$ & 3 \\
\hline 38836 & Gladwin & 3521 & 3596 & 3859 & 4016 & 43.91283 & -84.38746 & $18 \mathrm{~N}$ & $1 \mathrm{~W}$ & 35 & 747 & 12246 & $\mathrm{D}$ & 1 \\
\hline 39396 & Gladwin & 3732 & 3807 & 4044 & 4261 & 43.94729 & -84.50141 & $18 \mathrm{~N}$ & $2 W$ & 13 & 773 & 5088 & $\mathrm{O}$ & 1 \\
\hline 39724 & Gladwin & 3842 & 3917 & 4151 & 4380 & 44.02225 & -84.52102 & $19 \mathrm{~N}$ & $2 W$ & 23 & 865 & 5283 & $D$ & 1 \\
\hline 39772 & Gladwin & & & & & 43.96006 & -84.52642 & $18 \mathrm{~N}$ & $2 W$ & 10 & 859 & 12700 & $\mathrm{D}$ & \\
\hline 39772 & Gladwin & & & & & 43.96006 & -84.52642 & $18 \mathrm{~N}$ & $2 W$ & 10 & 859 & 12700 & $\mathrm{D}$ & \\
\hline 42226 & Gladwin & & & & & 43.95053 & -84.51438 & $18 \mathrm{~N}$ & $2 W$ & 14 & 813 & 12350 & $\mathrm{G}$ & \\
\hline 29703 & Grand Traverse & & & & & 44.58248 & -85.71683 & $25 \mathrm{~N}$ & $12 W$ & 11 & 1102 & 6015 & $\mathrm{D}$ & 1 \\
\hline 30656 & Grand Traverse & & & & & 44.73262 & -85.33713 & $27 \mathrm{~N}$ & $9 W$ & 13 & 995 & 6598 & $\mathrm{D}$ & 1 \\
\hline 31637 & Grand Traverse & & & & & 44.65625 & -85.54394 & $26 \mathrm{~N}$ & $10 W$ & 17 & 843 & 6113 & $\mathrm{O}$ & 5 \\
\hline 31836 & Grand Traverse & & & & & 44.54269 & -85.42537 & $25 N$ & $9 W$ & 20 & 1073 & 7550 & $\mathrm{D}$ & 5 \\
\hline 32109 & Grand Traverse & & & & & 44.65432 & -85.54807 & $26 \mathrm{~N}$ & $10 \mathrm{~W}$ & 17 & 916 & 6045 & $\mathrm{D}$ & 2 \\
\hline 32248 & Grand Traverse & & & & & 44.63890 & -85.61821 & $26 \mathrm{~N}$ & $11 \mathrm{~W}$ & 22 & 916 & 5958 & $\mathrm{G}$ & 2 \\
\hline 32341 & Grand Traverse & & & & & 44.69415 & -85.45847 & $27 \mathrm{~N}$ & $10 W$ & 36 & 953 & 6347 & $\mathrm{D}$ & 2 \\
\hline 32537 & Grand Traverse & & & & & 44.61921 & -85.48713 & $26 \mathrm{~N}$ & $10 \mathrm{~W}$ & 26 & 947 & 6675 & $\mathrm{D}$ & 2 \\
\hline 32619 & Grand Traverse & & & & & 44.63367 & -85.43059 & $26 \mathrm{~N}$ & $9 W$ & 20 & 931 & 6780 & $\mathrm{G}$ & 2 \\
\hline 32874 & Grand Traverse & & & & & 44.58374 & -85.71332 & $25 \mathrm{~N}$ & $12 \mathrm{~W}$ & 12 & 1104 & 6192 & $\mathrm{G}$ & 2 \\
\hline 33384 & Grand Traverse & & & & & 44.65560 & -85.54812 & $26 \mathrm{~N}$ & $10 \mathrm{~W}$ & 17 & 914 & 6060 & $\mathrm{D}$ & 2 \\
\hline 34132 & Grand Traverse & 2564 & 2609 & 2751 & & 44.57136 & -85.64389 & $25 \mathrm{~N}$ & $11 \mathrm{~W}$ & 9 & 1101 & $6469^{*}$ & $\mathrm{D}$ & 2 \\
\hline 34132 & Grand Traverse & & & & & 44.57136 & -85.64389 & $25 \mathrm{~N}$ & $11 \mathrm{~W}$ & 9 & 1101 & 0 & $\mathrm{D}$ & 2 \\
\hline 34292 & Grand Traverse & 2168 & 2218 & 2350 & & 44.63675 & -85.57964 & $26 \mathrm{~N}$ & $11 \mathrm{~W}$ & 24 & 915 & 11020 & $\mathrm{D}$ & 1 \\
\hline 34292 & Grand Traverse & & & & & 44.63675 & -85.57964 & $26 \mathrm{~N}$ & $11 \mathrm{~W}$ & 24 & 915 & 11020 & $\mathrm{D}$ & 2 \\
\hline 35638 & Grand Traverse & & & & & 44.65874 & -85.52173 & $26 \mathrm{~N}$ & $10 \mathrm{~W}$ & 9 & 825 & 6500 & $\mathrm{O}$ & \\
\hline 36364 & Grand Traverse & & & & & 44.67583 & -85.52848 & $26 \mathrm{~N}$ & $10 \mathrm{~W}$ & 4 & 857 & 6010 & $\mathrm{D}$ & \\
\hline 37345 & Grand Traverse & & & & & 44.67284 & -85.46775 & $26 \mathrm{~N}$ & 10W & 1 & 936 & 6550 & $\mathrm{D}$ & \\
\hline 37557 & Grand Traverse & & & & & 44.57654 & -85.58699 & $25 \mathrm{~N}$ & $11 \mathrm{~W}$ & 12 & 1091 & 6593 & $\mathrm{D}$ & \\
\hline 37800 & Grand Traverse & & & & & 44.60114 & -85.66773 & $26 \mathrm{~N}$ & $11 \mathrm{~W}$ & 32 & 1109 & 6090 & $\mathrm{D}$ & \\
\hline 37964 & Grand Traverse & & & & & 44.56795 & -85.76569 & $25 \mathrm{~N}$ & $12 W$ & 16 & 1137 & 6100 & $\mathrm{D}$ & \\
\hline 38763 & Grand Traverse & & & & & 44.67262 & -85.45829 & $26 \mathrm{~N}$ & $10 \mathrm{~W}$ & 1 & 900 & 6615 & $\mathrm{D}$ & \\
\hline 38839 & Grand Traverse & & & & & 44.71970 & -85.35076 & $27 \mathrm{~N}$ & $9 W$ & 24 & 940 & 7140 & $\mathrm{D}$ & \\
\hline
\end{tabular}


M. Le, MS Thesis, 2004

\begin{tabular}{|c|c|c|c|c|c|c|c|c|c|c|c|c|c|c|}
\hline Permit & Name & RGRC & DNDE & DRRV & DRB & Latitude & Longitude & Twn & Rng & Sec & $\mathrm{KB}$ & TD & Type & Omit \\
\hline 39047 & Grand Traverse & & & & & 44.67571 & -85.46102 & $26 \mathrm{~N}$ & $10 \mathrm{~W}$ & 1 & 900 & 6551 & $D$ & \\
\hline 29739 & Gratiot & 3138 & 3158 & 3319 & & 43.27301 & -84.57954 & $10 \mathrm{~N}$ & $2 W$ & 8 & 762 & 17466 & $\mathrm{D}$ & 1 \\
\hline 37377 & Gratiot & 3182 & 3202 & 3360 & & 43.25027 & -84.81571 & $10 \mathrm{~N}$ & $4 \mathrm{~W}$ & 17 & 774 & 3537 & $\mathrm{O}$ & 1 \\
\hline 36596 & Hillsdale & & 1399 & 1519 & & 41.87741 & -84.46888 & $7 S$ & $1 \mathrm{~W}$ & 7 & 1122 & 4047 & $\mathrm{O}$ & 1 \\
\hline 37886 & Hillsdale & & & & & 42.03494 & -84.55759 & $5 S$ & $2 W$ & 17 & 1156 & 4343 & $\mathrm{D}$ & \\
\hline 38358 & Hillsdale & & 1609 & 1678 & & 42.01550 & -84.54280 & $5 S$ & $2 W$ & 21 & 1166 & 4360 & $\mathrm{O}$ & 1 \\
\hline 38521 & Hillsdale & & & & & 42.00814 & -84.56242 & $5 S$ & $2 W$ & 29 & 1192 & 4400 & $\mathrm{D}$ & \\
\hline 38809 & Hillsdale & & & & & 42.07015 & -84.56732 & $5 S$ & $2 W$ & 5 & 1087 & 4370 & $\mathrm{D}$ & \\
\hline 38879 & Hillsdale & & 1639 & 1702 & & 42.06233 & -84.56262 & $5 S$ & $2 W$ & 5 & 1090 & 4360 & $\mathrm{D}$ & 1 \\
\hline 38904 & Hillsdale & & & & & 42.06604 & -84.57614 & $5 S$ & $2 W$ & 6 & 1129 & 4400 & $\mathrm{D}$ & \\
\hline 39030 & Hillsdale & & & & & 42.07005 & -84.56867 & $5 S$ & $2 W$ & 5 & 1087 & 4415 & $\mathrm{D}$ & \\
\hline 40414 & Hillsdale & & & & & 42.06252 & -84.64076 & $5 S$ & $3 W$ & 3 & 1107 & 5917 & $\mathrm{O}$ & \\
\hline 41359 & Hillsdale & & & & & 42.04817 & -84.55767 & $5 S$ & $2 W$ & 8 & 1137 & 4370 & $\mathrm{D}$ & \\
\hline 42345 & Hillsdale & & & & & 42.05620 & -84.57114 & $5 S$ & $2 W$ & 8 & 1140 & 4380 & $\mathrm{D}$ & \\
\hline 42346 & Hillsdale & & & & & 42.03729 & -84.55883 & $5 S$ & $2 W$ & 17 & 1156 & 4350 & $\mathrm{O}$ & \\
\hline 42829 & Hillsdale & & & & & 42.02825 & -84.55167 & $5 S$ & $2 W$ & 21 & 1141 & 4380 & $\mathrm{O}$ & \\
\hline 43862 & Hillsdale & & & & & 42.04095 & -84.57079 & $5 S$ & $2 W$ & 17 & 1172 & 4470 & $\mathrm{O}$ & \\
\hline 44285 & Hillsdale & & & & & 42.04554 & -84.56624 & $5 S$ & $2 W$ & 8 & 1153 & 4350 & $\mathrm{O}$ & \\
\hline 44319 & Hillsdale & & & & & 42.05883 & -84.56869 & $5 S$ & $2 W$ & 5 & 1141 & 4299 & $\mathrm{O}$ & \\
\hline 44503 & Hillsdale & & & & & 42.04264 & -84.55503 & $5 S$ & $2 W$ & 16 & 1143 & 4360 & $\mathrm{D}$ & \\
\hline 45242 & Hillsdale & & & & & 42.05615 & -84.56848 & $5 S$ & $2 W$ & 8 & 1131 & 4358 & $D$ & \\
\hline 24789 & Huron & 2621 & 2666 & 3036 & 3013 & 43.76668 & -83.00609 & $16 \mathrm{~N}$ & $12 \mathrm{E}$ & 36 & 763 & 7260 & $\mathrm{D}$ & 1 \\
\hline 29191 & Huron & 1683 & 1703 & 1963 & 1960 & 43.71690 & -82.66180 & $15 \mathrm{~N}$ & $15 \mathrm{E}$ & 26 & 711 & 2320 & $\mathrm{O}$ & 3 \\
\hline 33550 & Huron & 2397 & 2457 & 2810 & 2808 & 43.99671 & -83.02677 & $18 \mathrm{~N}$ & $12 \mathrm{E}$ & 12 & 644 & 3400 & $\mathrm{D}$ & 1 \\
\hline 39544 & Huron & 2687 & 2757 & 3131 & 3132 & 43.74653 & -83.35815 & $15 \mathrm{~N}$ & $9 \mathrm{E}$ & 1 & 651 & 11290 & $\mathrm{D}$ & 1 \\
\hline 28607 & Ingham & & 2400 & 2485 & 2574 & 42.53314 & -84.44778 & $2 \mathrm{~N}$ & $1 \mathrm{~W}$ & 29 & 939 & 7866 & $\mathrm{D}$ & 4 \\
\hline 29672 & Ingham & & 2324 & 2389 & & 42.42392 & -84.37833 & $1 \mathrm{~N}$ & $1 \mathrm{~W}$ & 36 & 977 & 6300 & $\mathrm{D}$ & 1 \\
\hline 26990 & Ionia & 2720 & 2730 & 2830 & 2940 & 42.94959 & -85.23059 & $7 N$ & $8 W$ & 35 & 820 & 6313 & $\mathrm{D}$ & 1 \\
\hline 36704 & Ionia & 2700 & 2710 & 2810 & 2931 & 42.87989 & -85.02622 & $6 \mathrm{~N}$ & $6 W$ & 28 & 822 & 6700 & $\mathrm{D}$ & 1 \\
\hline 39530 & Iosco & 3098 & 3198 & 3472 & & 44.28342 & -83.66049 & $22 \mathrm{~N}$ & $6 \mathrm{E}$ & 24 & 740 & 11244 & $\mathrm{D}$ & 1 \\
\hline 40267 & Iosco & 3009 & 3109 & 3385 & 3498 & 44.26797 & -83.80821 & $22 \mathrm{~N}$ & $5 \mathrm{E}$ & 27 & 776 & 11807 & $\mathrm{G}$ & 1 \\
\hline 21117 & Isabella & & & & & 43.66555 & -85.07580 & $15 \mathrm{~N}$ & $6 W$ & 30 & 1040 & 3825 & $\mathrm{D}$ & 1 \\
\hline
\end{tabular}


M. Le, MS Thesis, 2004

\begin{tabular}{|c|c|c|c|c|c|c|c|c|c|c|c|c|c|c|}
\hline Permit & Name & RGRC & DNDE & DRRV & DRB & Latitude & Longitude & Twn & Rng & Sec & KB & TD & Type & Omit \\
\hline 22826 & Isabella & & & & & 43.67836 & -85.00405 & $15 \mathrm{~N}$ & $6 W$ & 23 & 941 & 3770 & D & 1 \\
\hline 27193 & Isabella & & & & & 43.79783 & -85.07991 & $16 \mathrm{~N}$ & $6 W$ & 7 & 1078 & 4117 & $\mathrm{D}$ & 1 \\
\hline 27405 & Isabella & & & & & 43.73061 & -84.74671 & $16 \mathrm{~N}$ & $4 W$ & 36 & 785 & 4838 & $\mathrm{O}$ & 1 \\
\hline 27775 & Isabella & & & & & 43.72700 & -84.74641 & $15 \mathrm{~N}$ & $4 \mathrm{~W}$ & 1 & 782 & 4810 & $\mathrm{O}$ & 1 \\
\hline 30404 & Isabella & & & & & 43.48855 & -84.83860 & $13 \mathrm{~N}$ & $4 W$ & 30 & 874 & 3750 & $\mathrm{D}$ & 1 \\
\hline 30746 & Isabella & & & & & 43.53747 & -84.77136 & $13 \mathrm{~N}$ & $4 W$ & 10 & 855 & 3891 & $\mathrm{D}$ & 1 \\
\hline 32562 & Isabella & & & & & 43.80273 & -84.77076 & $16 \mathrm{~N}$ & $4 W$ & 3 & 877 & 4020 & $\mathrm{D}$ & 2 \\
\hline 33262 & Isabella & & & & & 43.73060 & -84.75170 & $16 \mathrm{~N}$ & $4 \mathrm{~W}$ & 35 & 795 & 4840 & $\mathrm{O}$ & 2 \\
\hline 34097 & Isabella & 3571 & 3601 & 3784 & 3923 & 43.49630 & -84.98342 & $13 \mathrm{~N}$ & $6 W$ & 24 & 903 & $5287^{*}$ & $\mathrm{D}$ & 1 \\
\hline 34166 & Isabella & & & & & 43.64823 & -84.85986 & $15 \mathrm{~N}$ & $5 W$ & 36 & 833 & 0 & $\mathrm{D}$ & 2 \\
\hline 34481 & Isabella & & & & & 43.62620 & -85.03594 & $14 \mathrm{~N}$ & $6 W$ & 4 & 960 & 3672 & $D$ & 2 \\
\hline 34572 & Isabella & 3663 & 3703 & 3931 & 4115 & 43.77653 & -84.69444 & $16 \mathrm{~N}$ & $3 W$ & 17 & 799 & 4886 & $\mathrm{O}$ & 1 \\
\hline 34960 & Isabella & & & & & 43.72625 & -84.75118 & $15 \mathrm{~N}$ & $4 W$ & 2 & 793 & 4843 & $\mathrm{O}$ & \\
\hline 35091 & Isabella & 3723 & 3763 & 3975 & 4147 & 43.74731 & -84.76140 & $16 \mathrm{~N}$ & $4 W$ & 26 & 822 & 4900 & $\mathrm{O}$ & 1 \\
\hline 35206 & Isabella & & & & & 43.67060 & -84.72436 & $15 \mathrm{~N}$ & $3 W$ & 19 & 759 & 4820 & $G$ & \\
\hline 35303 & Isabella & & & & & 43.72654 & -84.74607 & $15 \mathrm{~N}$ & $4 W$ & 1 & 786 & 4830 & $\mathrm{BD}$ & \\
\hline 35380 & Isabella & & & & & 43.72321 & -84.74668 & $15 \mathrm{~N}$ & $4 W$ & 1 & 791 & 4845 & $\mathrm{O}$ & \\
\hline 35425 & Isabella & & & & & 43.72607 & -84.75612 & $15 N$ & $4 W$ & 2 & 798 & 4846 & $\mathrm{O}$ & \\
\hline 35475 & Isabella & & & & & 43.73068 & -84.72161 & $16 \mathrm{~N}$ & $3 W$ & 31 & 783 & 5240 & $\mathrm{D}$ & \\
\hline 35540 & Isabella & & & & & 43.63620 & -84.64437 & $14 N$ & $3 W$ & 2 & 736 & 4670 & $\mathrm{O}$ & \\
\hline 35546 & Isabella & & & & & 43.73428 & -84.73680 & $16 \mathrm{~N}$ & $4 W$ & 36 & 796 & 4856 & $\mathrm{O}$ & \\
\hline 35586 & Isabella & & & & & 43.65988 & -84.72536 & $15 \mathrm{~N}$ & $3 W$ & 30 & 753 & 4745 & $\mathrm{G}$ & \\
\hline 35601 & Isabella & & & & & 43.75922 & -84.75698 & $16 \mathrm{~N}$ & $4 W$ & 23 & 804 & 4010 & $\mathrm{O}$ & \\
\hline 35607 & Isabella & & & & & 43.75961 & -84.74180 & $16 \mathrm{~N}$ & $4 W$ & 24 & 804 & 4970 & $\mathrm{D}$ & \\
\hline 35622 & Isabella & & & & & 43.66331 & -84.72427 & $15 \mathrm{~N}$ & $3 W$ & 30 & 756 & 4742 & $\mathrm{G}$ & \\
\hline 35637 & Isabella & 3633 & 3673 & 3889 & 4087 & 43.66700 & -84.71430 & $15 \mathrm{~N}$ & $3 W$ & 30 & 756 & 4775 & $\mathrm{O}$ & 1 \\
\hline 35651 & Isabella & & & & & 43.76281 & -84.75669 & $16 \mathrm{~N}$ & $4 \mathrm{~W}$ & 23 & 803 & 4956 & $\mathrm{D}$ & \\
\hline 35654 & Isabella & & & & & 43.75565 & -84.75117 & $16 \mathrm{~N}$ & $4 W$ & 26 & 823 & 4870 & $\mathrm{O}$ & \\
\hline 35711 & Isabella & 3639 & 3679 & 3873 & 4049 & 43.64877 & -84.68927 & $15 \mathrm{~N}$ & $3 W$ & 32 & 745 & 4740 & $\mathrm{D}$ & 1 \\
\hline 35744 & Isabella & & & & & 43.71565 & -84.75166 & $15 \mathrm{~N}$ & $4 \mathrm{~W}$ & 2 & 791 & 4829 & $\mathrm{O}$ & \\
\hline 35757 & Isabella & & & & & 43.71188 & -84.75166 & $15 \mathrm{~N}$ & $4 W$ & 11 & 792 & 4840 & $\mathrm{O}$ & \\
\hline 35808 & Isabella & & & & & 43.75193 & -84.76161 & $16 \mathrm{~N}$ & $4 W$ & 26 & 824 & 4950 & $\mathrm{O}$ & \\
\hline
\end{tabular}


M. Le, MS Thesis, 2004

\begin{tabular}{|c|c|c|c|c|c|c|c|c|c|c|c|c|c|c|}
\hline Permit & Name & RGRC & DNDE & DRRV & DRB & Latitude & Longitude & Twn & Rng & Sec & KB & TD & Type & Omit \\
\hline 35831 & Isabella & & & & & 43.72301 & -84.75661 & $15 N$ & $4 W$ & 2 & 797 & 4850 & 0 & \\
\hline 35944 & Isabella & & & & & 43.76281 & -84.76161 & $16 \mathrm{~N}$ & $4 \mathrm{~W}$ & 23 & 827 & 4910 & $\mathrm{BD}$ & \\
\hline 35986 & Isabella & & & & & 43.71940 & -84.75165 & $15 \mathrm{~N}$ & $4 W$ & 2 & 791 & 4825 & $\mathrm{O}$ & \\
\hline 35987 & Isabella & & & & & 43.70851 & -84.74668 & $15 \mathrm{~N}$ & $4 W$ & 12 & 786 & 4836 & $\mathrm{O}$ & \\
\hline 35991 & Isabella & & & & & 43.75979 & -84.68052 & $16 \mathrm{~N}$ & $3 W$ & 21 & 772 & 4900 & $\mathrm{D}$ & \\
\hline 36005 & Isabella & & & & & 43.71180 & -84.74669 & $15 \mathrm{~N}$ & $4 W$ & 12 & 787 & 4835 & $\mathrm{O}$ & \\
\hline 36040 & Isabella & & & & & 43.71571 & -84.74669 & $15 \mathrm{~N}$ & $4 W$ & 1 & 789 & 4840 & $\mathrm{O}$ & \\
\hline 36047 & Isabella & & & & & 43.66727 & -84.71930 & $15 \mathrm{~N}$ & $3 W$ & 30 & 756 & 4760 & $\mathrm{O}$ & \\
\hline 36049 & Isabella & & & & & 43.62133 & -84.63002 & $14 N$ & $3 W$ & 11 & 725 & 4672 & $\mathrm{O}$ & \\
\hline 36073 & Isabella & & & & & 43.71194 & -84.73677 & $15 \mathrm{~N}$ & $4 \mathrm{~W}$ & 12 & 785 & 4859 & $\mathrm{O}$ & \\
\hline 36142 & Isabella & & & & & 43.70825 & -84.75165 & $15 \mathrm{~N}$ & $4 W$ & 11 & 785 & 4838 & $\mathrm{O}$ & \\
\hline 36146 & Isabella & & & & & 43.70823 & -84.75630 & $15 \mathrm{~N}$ & $4 W$ & 11 & 780 & 4835 & $\mathrm{O}$ & \\
\hline 36147 & Isabella & & & & & 43.71163 & -84.75547 & $15 \mathrm{~N}$ & $4 W$ & 11 & 785 & 4830 & $\mathrm{O}$ & \\
\hline 36151 & Isabella & & & & & 43.62538 & -84.63438 & $14 N$ & $3 \mathrm{~W}$ & 11 & 721 & 4685 & $\mathrm{O}$ & \\
\hline 36168 & Isabella & & & & & 43.74153 & -84.68089 & $16 \mathrm{~N}$ & $3 W$ & 33 & 771 & 4548 & $\mathrm{O}$ & \\
\hline 36181 & Isabella & & & & & 43.70145 & -84.73184 & $15 \mathrm{~N}$ & $4 W$ & 12 & 775 & 4833 & $\mathrm{O}$ & \\
\hline 36202 & Isabella & & & & & 43.69723 & -84.75165 & $15 \mathrm{~N}$ & $4 W$ & 14 & 773 & 4830 & $\mathrm{D}$ & \\
\hline 36204 & Isabella & & & & & 43.63619 & -84.66458 & $14 N$ & $3 W$ & 3 & 741 & 4695 & $\mathrm{O}$ & \\
\hline 36262 & Isabella & 3816 & 3841 & 4017 & 4200 & 43.61628 & -85.04563 & $14 \mathrm{~N}$ & $6 W$ & 9 & 1100 & 4930 & $\mathrm{D}$ & 1 \\
\hline 36264 & Isabella & & & & & 43.71208 & -84.74176 & $15 \mathrm{~N}$ & $4 W$ & 12 & 784 & 4840 & $\mathrm{O}$ & \\
\hline 36270 & Isabella & & & & & 43.71960 & -84.74668 & $15 \mathrm{~N}$ & $4 W$ & 1 & 790 & 4840 & $\mathrm{O}$ & \\
\hline 36271 & Isabella & & & & & 43.71580 & -84.74179 & $15 \mathrm{~N}$ & $4 W$ & 1 & 787 & 4841 & $\mathrm{O}$ & \\
\hline 36281 & Isabella & & & & & 43.70110 & -84.78153 & $15 \mathrm{~N}$ & $4 W$ & 10 & 787 & 4660 & $\mathrm{D}$ & \\
\hline 36282 & Isabella & & & & & 43.74959 & -84.86242 & $16 \mathrm{~N}$ & $5 W$ & 25 & 887 & 5160 & $D$ & \\
\hline 36366 & Isabella & & & & & 43.63625 & -84.63939 & $14 \mathrm{~N}$ & $3 W$ & 2 & 734 & 4690 & $\mathrm{O}$ & \\
\hline 36367 & Isabella & & & & & 43.62133 & -84.63437 & $14 \mathrm{~N}$ & $3 W$ & 11 & 728 & 4690 & $\mathrm{O}$ & \\
\hline 36387 & Isabella & & & & & \begin{tabular}{|l|}
43.63620 \\
\end{tabular} & -84.65440 & $14 \mathrm{~N}$ & $3 \mathrm{~W}$ & 3 & 739 & 4680 & $\mathrm{O}$ & \\
\hline 36390 & Isabella & & & & & 43.71235 & -84.73183 & $15 \mathrm{~N}$ & $4 W$ & 12 & 783 & 4875 & $\mathrm{O}$ & \\
\hline 36437 & Isabella & & & & & 43.70467 & -84.75167 & $15 \mathrm{~N}$ & $4 W$ & 11 & 785 & 4835 & $\mathrm{O}$ & \\
\hline 36449 & Isabella & & & & & 43.72020 & -84.75626 & $15 \mathrm{~N}$ & $4 W$ & 2 & 795 & 4880 & $\mathrm{O}$ & \\
\hline 36491 & Isabella & & & & & 43.71960 & -84.73679 & $15 \mathrm{~N}$ & $4 W$ & 1 & 789 & 4850 & $\mathrm{O}$ & \\
\hline 36520 & Isabella & & & & & 43.76260 & -84.76659 & $16 \mathrm{~N}$ & $4 W$ & 23 & 822 & 3785 & $\mathrm{O}$ & \\
\hline
\end{tabular}


M. Le, MS Thesis, 2004

\begin{tabular}{|c|c|c|c|c|c|c|c|c|c|c|c|c|c|c|}
\hline Permit & Name & RGRC & DNDE & DRRV & DRB & Latitude & Longitude & Twn & Rng & Sec & $\mathrm{KB}$ & TD & Type & Omit \\
\hline 36524 & Isabella & 3810 & 3835 & 4032 & 4226 & 43.69544 & -84.84188 & $15 \mathrm{~N}$ & $4 W$ & 18 & 878 & 5000 & $G$ & 2 \\
\hline 36545 & Isabella & & & & & 43.71554 & -84.75623 & $15 N$ & $4 \mathrm{~W}$ & 2 & 793 & 4886 & $\mathrm{O}$ & \\
\hline 36548 & Isabella & & & & & 43.73387 & -84.74662 & $16 \mathrm{~N}$ & $4 \mathrm{~W}$ & 36 & 795 & 4846 & $\mathrm{O}$ & \\
\hline 36549 & Isabella & & & & & 43.70494 & -84.74172 & $15 \mathrm{~N}$ & $4 \mathrm{~W}$ & 12 & 781 & 4840 & $\mathrm{O}$ & \\
\hline 36550 & Isabella & & & & & 43.70494 & -84.74667 & $15 \mathrm{~N}$ & $4 \mathrm{~W}$ & 12 & 785 & 5125 & $\mathrm{O}$ & \\
\hline 36551 & Isabella & & & & & 43.70853 & -84.74174 & $15 \mathrm{~N}$ & $4 \mathrm{~W}$ & 12 & 785 & 4840 & $\mathrm{O}$ & \\
\hline 36556 & Isabella & & & & & 43.74868 & -84.76599 & $16 \mathrm{~N}$ & $4 W$ & 26 & 817 & 4875 & $\mathrm{O}$ & \\
\hline 36607 & Isabella & & & & & 43.71960 & -84.74176 & $15 \mathrm{~N}$ & $4 \mathrm{~W}$ & 1 & 794 & 4841 & $\mathrm{O}$ & \\
\hline 36638 & Isabella & & & & & 43.74510 & -84.75638 & $16 \mathrm{~N}$ & $4 \mathrm{~W}$ & 26 & 816 & 4873 & $\mathrm{O}$ & \\
\hline 36646 & Isabella & & & & & 43.74262 & -84.87223 & $16 \mathrm{~N}$ & $5 W$ & 26 & 924 & 5145 & $\mathrm{G}$ & \\
\hline 36675 & Isabella & & & & & 43.63260 & -84.64480 & $14 \mathrm{~N}$ & $3 W$ & 2 & 738 & 4675 & $\mathrm{O}$ & \\
\hline 36696 & Isabella & & & & & 43.73421 & -84.75161 & $16 \mathrm{~N}$ & $4 W$ & 35 & 798 & 4850 & $\mathrm{O}$ & \\
\hline 36697 & Isabella & & & & & 43.72330 & -84.74174 & $15 \mathrm{~N}$ & $4 W$ & 1 & 790 & 4845 & $\mathrm{O}$ & \\
\hline 36762 & Isabella & 3678 & 3718 & 3924 & 4093 & 43.73781 & -84.75149 & $16 \mathrm{~N}$ & $4 \mathrm{~W}$ & 35 & 795 & 4860 & $\mathrm{O}$ & 1 \\
\hline 36783 & Isabella & & & & & 43.73059 & -84.75650 & $16 \mathrm{~N}$ & $4 \mathrm{~W}$ & 35 & 805 & 4830 & $\mathrm{O}$ & \\
\hline 36784 & Isabella & & & & & 43.73813 & -84.68621 & $16 \mathrm{~N}$ & $3 W$ & 33 & 770 & 4835 & $\mathrm{O}$ & \\
\hline 36797 & Isabella & & & & & 43.74506 & -84.76622 & $16 \mathrm{~N}$ & $4 W$ & 26 & 810 & 4600 & $\mathrm{O}$ & \\
\hline 36805 & Isabella & & & & & 43.75937 & -84.77156 & $16 \mathrm{~N}$ & $4 W$ & 22 & 840 & 3795 & $\mathrm{O}$ & \\
\hline 36806 & Isabella & & & & & 43.68821 & -84.83127 & $15 \mathrm{~N}$ & $4 W$ & 18 & 853 & 4992 & G & \\
\hline 36807 & Isabella & & & & & 43.71590 & -84.73679 & $15 \mathrm{~N}$ & $4 \mathrm{~W}$ & 1 & 783 & 4830 & $\mathrm{O}$ & \\
\hline 36826 & Isabella & & & & & 43.73788 & -84.74591 & $16 \mathrm{~N}$ & $4 \mathrm{~W}$ & 36 & 796 & 4850 & $\mathrm{O}$ & \\
\hline 36839 & Isabella & & & & & 43.74154 & -84.68556 & $16 \mathrm{~N}$ & $3 W$ & 33 & 769 & 4821 & $\mathrm{O}$ & \\
\hline 36894 & Isabella & & & & & 43.76600 & -84.79170 & $16 \mathrm{~N}$ & $4 W$ & 21 & 884 & 3865 & $\mathrm{D}$ & \\
\hline 36900 & Isabella & & & & & 43.74120 & -84.75644 & $16 \mathrm{~N}$ & $4 W$ & 35 & 802 & 4849 & $\mathrm{O}$ & \\
\hline 36928 & Isabella & & & & & 43.73421 & -84.75650 & $16 \mathrm{~N}$ & $4 \mathrm{~W}$ & 35 & 807 & 4860 & $\mathrm{O}$ & \\
\hline 36935 & Isabella & & & & & 43.74125 & -84.68084 & $16 \mathrm{~N}$ & $3 W$ & 33 & 770 & 5243 & $\mathrm{BD}$ & \\
\hline 36936 & Isabella & & & & & 43.67422 & -84.72472 & $15 \mathrm{~N}$ & $3 W$ & 19 & 756 & 4755 & $G$ & \\
\hline 36944 & Isabella & & & & & 43.66692 & -84.72959 & $15 \mathrm{~N}$ & $4 W$ & 25 & 759 & 4754 & $\mathrm{BD}$ & \\
\hline 36951 & Isabella & 3913 & 3943 & 4154 & 4332 & 43.78172 & -85.08731 & $16 \mathrm{~N}$ & $6 W$ & 18 & 1092 & 5160 & $\mathrm{D}$ & 3 \\
\hline 37036 & Isabella & & & & & 43.73790 & -84.74174 & $16 \mathrm{~N}$ & $4 W$ & 36 & 794 & 4840 & $\mathrm{O}$ & \\
\hline 37038 & Isabella & & & & & 43.73393 & -84.74174 & $16 \mathrm{~N}$ & $4 W$ & 36 & 795 & 4845 & $\mathrm{O}$ & \\
\hline 37075 & Isabella & & & & & 43.73808 & -84.69125 & $16 \mathrm{~N}$ & $3 W$ & 32 & 770 & 4845 & $\mathrm{O}$ & \\
\hline
\end{tabular}

A-11 
M. Le, MS Thesis, 2004

\begin{tabular}{|c|c|c|c|c|c|c|c|c|c|c|c|c|c|c|}
\hline Permit & Name & RGRC & DNDE & DRRV & DRB & Latitude & Longitude & Twn & Rng & Sec & KB & TD & Type & Omit \\
\hline 37077 & Isabella & & & & & 43.73057 & -84.76149 & $16 \mathrm{~N}$ & $4 W$ & 35 & 806 & 4880 & 0 & \\
\hline 37078 & Isabella & & & & & 43.73421 & -84.76148 & $16 \mathrm{~N}$ & $4 W$ & 35 & 807 & 4865 & $\mathrm{O}$ & \\
\hline 37114 & Isabella & & & & & 43.74592 & -84.86722 & $16 \mathrm{~N}$ & $5 W$ & 25 & 905 & 5150 & $\mathrm{G}$ & \\
\hline 37133 & Isabella & 3934 & 3959 & 4163 & 4353 & 43.74625 & -84.87729 & $16 \mathrm{~N}$ & $5 W$ & 26 & 939 & 5160 & $\mathrm{D}$ & 1 \\
\hline 37147 & Isabella & & & & & 43.74533 & -84.69132 & $16 \mathrm{~N}$ & $3 W$ & 29 & 774 & 4850 & $\mathrm{O}$ & \\
\hline 37148 & Isabella & 3651 & 3691 & 3911 & 4091 & 43.74534 & -84.68579 & $16 \mathrm{~N}$ & $3 W$ & 28 & 763 & 4845 & $\mathrm{O}$ & 2 \\
\hline 37158 & Isabella & & & & & 43.70824 & -84.76157 & $15 \mathrm{~N}$ & $4 \mathrm{~W}$ & 11 & 778 & 4830 & $\mathrm{D}$ & \\
\hline 37169 & Isabella & & & & & 43.71024 & -84.85220 & $15 \mathrm{~N}$ & $5 W$ & 12 & 843 & 5029 & $\mathrm{D}$ & \\
\hline 37170 & Isabella & 3671 & 3711 & 3923 & 4091 & 43.70828 & -84.73677 & $15 \mathrm{~N}$ & $4 W$ & 12 & 782 & 4885 & $\mathrm{O}$ & 1 \\
\hline 37179 & Isabella & & & & & 43.70124 & -84.74175 & $15 \mathrm{~N}$ & $4 W$ & 12 & 774 & 4825 & $\mathrm{O}$ & \\
\hline 37209 & Isabella & & & & & 43.74149 & -84.75141 & $16 \mathrm{~N}$ & $4 W$ & 35 & 798 & 4860 & $\mathrm{O}$ & \\
\hline 37222 & Isabella & & & & & 43.76247 & -84.77163 & $16 \mathrm{~N}$ & $4 W$ & 22 & 827 & 3834 & $\mathrm{BD}$ & \\
\hline 37242 & Isabella & 3684 & 3724 & 3957 & 4140 & 43.71981 & -84.65113 & $15 \mathrm{~N}$ & $3 W$ & 3 & 761 & 4900 & $\mathrm{D}$ & 1 \\
\hline 37243 & Isabella & & & & & 43.64926 & -85.01507 & $15 \mathrm{~N}$ & $6 \mathrm{~W}$ & 34 & 943 & 3700 & $\mathrm{D}$ & \\
\hline 37290 & Isabella & & & & & 43.73509 & -84.68619 & $16 \mathrm{~N}$ & $3 W$ & 33 & 766 & 4840 & $\mathrm{D}$ & \\
\hline 37350 & Isabella & & & & & 43.62121 & -84.61930 & $14 \mathrm{~N}$ & $3 W$ & 12 & 717 & 4670 & $\mathrm{O}$ & \\
\hline 37380 & Isabella & & & & & 43.73452 & -84.67617 & $16 \mathrm{~N}$ & $3 W$ & 33 & 761 & 4823 & $\mathrm{D}$ & \\
\hline 37462 & Isabella & & & & & 43.73791 & -84.73192 & $16 \mathrm{~N}$ & $4 \mathrm{~W}$ & 36 & 788 & 4830 & $\mathrm{O}$ & \\
\hline 37482 & Isabella & & & & & 43.74151 & -84.74176 & $16 \mathrm{~N}$ & $4 W$ & 36 & 794 & 4901 & $\mathrm{O}$ & \\
\hline 37591 & Isabella & & & & & 43.65945 & -84.72920 & $15 \mathrm{~N}$ & $4 W$ & 25 & 752 & 4760 & $\mathrm{D}$ & \\
\hline 37672 & Isabella & 3716 & 3741 & 3940 & 4124 & 43.73860 & -85.06017 & $16 \mathrm{~N}$ & $6 W$ & 32 & 998 & 5010 & $\mathrm{D}$ & 1 \\
\hline 37724 & Isabella & & & & & 43.75935 & -84.77601 & $16 \mathrm{~N}$ & $4 W$ & 22 & 847 & 3810 & $\mathrm{O}$ & \\
\hline 37744 & Isabella & & & & & 43.67469 & -84.72993 & $15 \mathrm{~N}$ & $4 W$ & 24 & 763 & 4765 & $\mathrm{G}$ & \\
\hline 37820 & Isabella & & & & & 43.69171 & -84.85235 & $15 \mathrm{~N}$ & $5 W$ & 13 & 854 & 4971 & $\mathrm{O}$ & \\
\hline 37909 & Isabella & 3670 & 3700 & 3888 & & 43.60371 & -84.90895 & $14 \mathrm{~N}$ & $5 W$ & 16 & 880 & 3930 & D & 1 \\
\hline 38007 & Isabella & & & & & 43.73782 & -84.75650 & $16 \mathrm{~N}$ & $4 \mathrm{~W}$ & 35 & 809 & 4900 & $\mathrm{O}$ & \\
\hline 38037 & Isabella & & & & & 43.73279 & -84.95032 & $16 \mathrm{~N}$ & $5 W$ & 31 & 950 & 4958 & $\mathrm{O}$ & \\
\hline 38144 & Isabella & & & & & 43.64309 & -84.65927 & $15 \mathrm{~N}$ & $3 W$ & 34 & 740 & 4675 & $\mathrm{D}$ & \\
\hline 38512 & Isabella & & & & & 43.63232 & -84.63939 & $14 \mathrm{~N}$ & $3 W$ & 2 & 737 & 4670 & $\mathrm{O}$ & \\
\hline 38537 & Isabella & & & & & 43.67422 & -84.71965 & $15 \mathrm{~N}$ & $3 W$ & 19 & 753 & 4755 & $\mathrm{O}$ & \\
\hline 39059 & Isabella & & & & & 43.75901 & -84.76623 & $16 \mathrm{~N}$ & $4 \mathrm{~W}$ & 23 & 830 & 3800 & $B D$ & \\
\hline 39806 & Isabella & & & & & 43.75538 & -84.76641 & $16 \mathrm{~N}$ & $4 \mathrm{~W}$ & 26 & 820 & 3798 & $\mathrm{D}$ & \\
\hline
\end{tabular}


M. Le, MS Thesis, 2004

\begin{tabular}{|c|c|c|c|c|c|c|c|c|c|c|c|c|c|c|}
\hline Permit & Name & RGRC & DNDE & DRRV & DRB & Latitude & Longitude & Twn & Rng & Sec & $\mathrm{KB}$ & TD & Type & Omit \\
\hline 40039 & Isabella & 3529 & 3569 & 3772 & 3939 & 43.63230 & -84.64942 & $14 N$ & $3 W$ & 3 & 738 & 4650 & $G$ & 1 \\
\hline 40292 & Isabella & & & & & 43.64733 & -84.72481 & $15 \mathrm{~N}$ & $3 W$ & 31 & 780 & 10955 & $\mathrm{D}$ & \\
\hline 40292 & Isabella & & & & & 43.64733 & -84.72481 & $15 \mathrm{~N}$ & $3 W$ & 31 & 780 & 10955 & $\mathrm{D}$ & \\
\hline 40823 & Isabella & & & & & 43.62179 & -85.05070 & $14 \mathrm{~N}$ & $6 W$ & 8 & 1155 & 10306 & $\mathrm{D}$ & \\
\hline 40823 & Isabella & & & & & 43.62179 & -85.05070 & $14 \mathrm{~N}$ & $6 \mathrm{~W}$ & 8 & 1155 & 10306 & $\mathrm{D}$ & \\
\hline 41254 & Isabella & & & & & 43.60414 & -84.61214 & $14 \mathrm{~N}$ & $3 W$ & 13 & 744 & 10900 & $\mathrm{D}$ & \\
\hline 42540 & Isabella & & & & & 43.69388 & -84.73744 & $15 \mathrm{~N}$ & $4 \mathrm{~W}$ & 13 & 781 & 11010 & $\mathrm{D}$ & \\
\hline 54950 & Isabella & & & & & 43.75560 & -84.74607 & $16 \mathrm{~N}$ & $04 \mathrm{~W}$ & 25 & 800 & 3763 & $\mathrm{D}$ & \\
\hline 22275 & Jackson & & & & & 42.17914 & -84.45066 & $3 S$ & $1 \mathrm{~W}$ & 29 & 997 & 6038 & $\mathrm{D}$ & 2 \\
\hline 35153 & Jackson & & 1918 & 1981 & 2046 & 42.24587 & -84.14951 & $3 S$ & $2 E$ & 1 & 1041 & 5202 & $\mathrm{D}$ & 2 \\
\hline 36384 & Jackson & & 1698 & 1763 & & 42.12073 & -84.48516 & $4 S$ & $2 W$ & 13 & 1057 & 4598 & $\mathrm{O}$ & 1 \\
\hline 37237 & Jackson & & & & & 42.10869 & -84.59496 & $4 S$ & $3 W$ & 24 & 1138 & 4700 & $D$ & \\
\hline 38927 & Jackson & & & & & 42.08065 & -84.57768 & $4 S$ & $2 W$ & 31 & 1071 & 4400 & $\mathrm{O}$ & \\
\hline 38927 & Jackson & & & & & 42.08065 & -84.57768 & $4 S$ & $2 W$ & 31 & 1071 & 4400 & $\mathrm{O}$ & \\
\hline 39014 & Jackson & & 1744 & 1799 & 1810 & 42.12406 & -84.58667 & $4 S$ & $2 W$ & 18 & 1127 & 4550 & $\mathrm{D}$ & 1 \\
\hline 39014 & Jackson & & & & & 42.12406 & -84.58667 & $4 S$ & $2 W$ & 18 & 1127 & 4550 & $\mathrm{D}$ & \\
\hline 39273 & Jackson & & & & & 42.10696 & -84.58643 & $4 S$ & $2 W$ & 19 & 1134 & 4600 & $\mathrm{D}$ & \\
\hline 39273 & Jackson & & & & & 42.10696 & -84.58643 & $4 S$ & $2 W$ & 19 & 1134 & 4600 & $\mathrm{D}$ & \\
\hline 43040 & Jackson & & & & & 42.09299 & -84.56221 & $4 S$ & $2 W$ & 29 & 1090 & 5025 & $\mathrm{D}$ & \\
\hline 43040 & Jackson & & & & & 42.09299 & -84.56221 & $4 S$ & $2 W$ & 29 & 1090 & 5025 & $\mathrm{D}$ & \\
\hline 20572 & Kalamazoo & & & & & 42.34982 & -85.45585 & $1 \mathrm{~S}$ & $10 \mathrm{~W}$ & 27 & 916 & 4125 & $\mathrm{D}$ & 2 \\
\hline 23035 & Kalamazoo & & & & & 42.39777 & -85.70501 & $1 \mathrm{~S}$ & $12 W$ & 10 & 789 & 3860 & $\mathrm{D}$ & 1 \\
\hline 27508 & Kalamazoo & & 1408 & 1444 & 1528 & 42.15817 & -85.52424 & $3 S$ & $10 W$ & 31 & 874 & 3660 & $\mathrm{D}$ & 1 \\
\hline 99989_077 & Kalamazoo & & 1452 & 1508 & 1576 & 42.20914 & -85.55411 & $03 S$ & $11 \mathrm{~W}$ & 14 & 886 & $5588^{*}$ & $\mathrm{OI}$ & \\
\hline 29096 & Kalkaska & & & & & 44.76725 & -85.18255 & $27 \mathrm{~N}$ & $7 \mathrm{~W}$ & 5 & 1058 & 6688 & $\mathrm{O}$ & 1 \\
\hline 29209 & Kalkaska & & & & & 44.75677 & -85.23966 & $27 N$ & $8 W$ & 11 & 1033 & 6765 & $\mathrm{O}$ & 2 \\
\hline 29304 & Kalkaska & & & & & 44.71218 & -85.28484 & $27 \mathrm{~N}$ & $8 W$ & 28 & 1010 & 6815 & $\mathrm{O}$ & 1 \\
\hline 29474 & Kalkaska & & & & & 44.69949 & -85.33438 & $27 \mathrm{~N}$ & $8 W$ & 30 & 937 & 7224 & $\mathrm{GC}$ & 1 \\
\hline 29657 & Kalkaska & & & & & 44.74642 & -85.22872 & $27 \mathrm{~N}$ & $8 W$ & 12 & 1029 & 6759 & $\mathrm{BD}$ & 1 \\
\hline 29794 & Kalkaska & & & & & 44.73553 & -85.24467 & $27 \mathrm{~N}$ & $8 W$ & 14 & 1027 & 6790 & $\mathrm{BD}$ & 1 \\
\hline 30473 & Kalkaska & & & & & 44.72065 & -85.31048 & $27 N$ & $8 W$ & 20 & 984 & 6750 & $\mathrm{O}$ & 1 \\
\hline 30495 & Kalkaska & & & & & 44.76025 & -85.20938 & $27 \mathrm{~N}$ & $7 \mathrm{~W}$ & 6 & 962 & 6550 & $D$ & 2 \\
\hline
\end{tabular}


M. Le, MS Thesis, 2004

\begin{tabular}{|c|c|c|c|c|c|c|c|c|c|c|c|c|c|c|}
\hline Permit & Name & RGRC & DNDE & DRRV & DRB & Latitude & Longitude & Twn & Rng & Sec & $\mathrm{KB}$ & TD & Type & Omit \\
\hline 31983 & Kalkaska & & & & & 44.74560 & -85.26994 & $27 N$ & $8 W$ & 10 & 1010 & 7743 & 0 & 1 \\
\hline 33596 & Kalkaska & 3335 & 3395 & 3588 & 3808 & 44.53893 & -85.19657 & $25 N$ & $7 \mathrm{~W}$ & 30 & 1091 & 10107 & $\mathrm{D}$ & 1 \\
\hline 33944 & Kalkaska & 2636 & 2711 & 2877 & & 44.77372 & -85.07295 & $28 \mathrm{~N}$ & $6 \mathrm{~W}$ & 31 & 1186 & 6945 & $\mathrm{G}$ & 1 \\
\hline 33944 & Kalkaska & & & & & 44.77372 & -85.07295 & $28 \mathrm{~N}$ & $6 W$ & 31 & 1186 & 6945 & GS & 2 \\
\hline 34208 & Kalkaska & & & & & 44.51408 & -85.27242 & $25 \mathrm{~N}$ & $8 W$ & 34 & 1018 & 2895 & $G$ & 2 \\
\hline 34613 & Kalkaska & 2745 & 2825 & 3073 & & 44.81292 & -84.88298 & $28 \mathrm{~N}$ & $5 W$ & 23 & 1315 & 9221 & $\mathrm{D}$ & 1 \\
\hline 36703 & Kalkaska & & & & & 44.75474 & -85.26054 & $27 \mathrm{~N}$ & $8 W$ & 10 & 952 & 6587 & $\mathrm{D}$ & \\
\hline 36937 & Kalkaska & & & & & 44.72404 & -85.26068 & $27 \mathrm{~N}$ & $8 W$ & 22 & 1028 & 6853 & $\mathrm{O}$ & \\
\hline 36947 & Kalkaska & & & & & 44.72198 & -85.27236 & $27 \mathrm{~N}$ & $8 W$ & 22 & 989 & 6800 & $\mathrm{D}$ & \\
\hline 37414 & Kalkaska & & & & & 44.75235 & -85.26840 & $27 N$ & $8 W$ & 10 & 965 & 6640 & $\mathrm{D}$ & \\
\hline 44882 & Kalkaska & 3087 & 3142 & 3329 & & 44.51854 & -85.30970 & $25 \mathrm{~N}$ & $8 W$ & 32 & 1081 & 10475 & $\mathrm{GC}$ & 2 \\
\hline 26946 & Kent & & 2784 & 2906 & 3011 & 43.02479 & -85.34450 & $7 \mathrm{~N}$ & $9 W$ & 2 & 944 & 6598 & $\mathrm{D}$ & 1 \\
\hline 27296 & Kent & 2917 & 2922 & 3055 & 3153 & 43.12661 & -85.46343 & $9 \mathrm{~N}$ & $10 \mathrm{~W}$ & 35 & & 7814 & $\mathrm{BD}$ & 3 \\
\hline 00156BD & Kent & & 2431 & 2530 & 2628 & 42.85551 & -85.36301 & $5 \mathrm{~N}$ & $9 W$ & 3 & 857 & 6393 & $\mathrm{D}$ & 1 \\
\hline 34116 & Lapeer & & & & & 43.24880 & -83.27914 & $10 \mathrm{~N}$ & $10 \mathrm{E}$ & 34 & 801 & 0 & $\mathrm{O}$ & 2 \\
\hline 37408 & Lapeer & & & & & 43.09512 & -82.99440 & $8 \mathrm{~N}$ & $12 \mathrm{E}$ & 25 & 813 & 7057 & $\mathrm{D}$ & \\
\hline 41590 & Lapeer & 2329 & 2339 & 2522 & 2542 & 43.21440 & -83.19150 & $9 N$ & $11 \mathrm{E}$ & 9 & 805 & 8670 & $\mathrm{D}$ & 1 \\
\hline 22627 & Leelanau & & & & & 45.02820 & -85.68315 & $30 \mathrm{~N}$ & $11 \mathrm{~W}$ & 6 & 925 & 5750 & $\mathrm{D}$ & 2 \\
\hline 28168 & Lenawee & & 1320 & 1408 & & 41.97464 & -84.20445 & $6 S$ & $2 E$ & 4 & 1008 & 4075 & $\mathrm{D}$ & 2 \\
\hline 28531 & Lenawee & & 603 & 684 & & 41.74535 & -84.02288 & $8 S$ & $3 E$ & 26 & 746 & 3146 & $\mathrm{D}$ & 3 \\
\hline 31792 & Lenawee & & 390 & 396 & & 42.05428 & -83.83422 & $5 S$ & $5 E$ & 9 & 772 & 3800 & $D$ & 1 \\
\hline 34689 & Lenawee & & & & & 41.99368 & -84.00643 & $5 S$ & $3 E$ & 36 & 853 & 4220 & $\mathrm{D}$ & \\
\hline 38576 & Lenawee & & 861 & 966 & & 41.90936 & -83.96994 & $6 S$ & $4 \mathrm{E}$ & 32 & 852 & 3690 & $\mathrm{D}$ & 1 \\
\hline 25868 & Livingston & & 2139 & 2200 & 2295 & 42.56152 & -83.94038 & $2 \mathrm{~N}$ & $4 \mathrm{E}$ & 14 & 939 & 7205 & $\mathrm{D}$ & 3 \\
\hline 26999 & Livingston & & 1050 & 1117 & & 42.47806 & -83.70638 & $1 \mathrm{~N}$ & $6 \mathrm{E}$ & 14 & 936 & 5560 & $D$ & 1 \\
\hline 27986 & Livingston & & & & & 42.67363 & -83.82514 & $3 N$ & $5 E$ & 11 & 980 & 7589 & $\mathrm{D}$ & 1 \\
\hline 36447 & Livingston & & 2048 & 2116 & 2197 & 42.56985 & -84.07438 & $2 \mathrm{~N}$ & $3 E$ & 10 & 924 & 4600 & $\mathrm{D}$ & 2 \\
\hline 37893 & Livingston & & 1527 & 1592 & 1748 & 42.73344 & -83.82823 & $4 \mathrm{~N}$ & $5 E$ & 23 & 935 & 7548 & $\mathrm{D}$ & 2 \\
\hline 40438 & Livingston & 1238 & 1243 & 1314 & & 42.67933 & -84.06337 & $3 N$ & $3 E$ & 2 & 940 & 7450 & $\mathrm{G}$ & 1 \\
\hline 33737 & Macomb & & 1186 & 1325 & & 42.84378 & -82.75331 & $5 \mathrm{~N}$ & $14 \mathrm{E}$ & 24 & 739 & 5400 & D & 2 \\
\hline 36238 & Macomb & & 1187 & 1372 & & 42.66266 & -82.91387 & $3 N$ & $13 \mathrm{E}$ & 22 & 618 & 4571 & $\mathrm{D}$ & 1 \\
\hline 39859 & Macomb & & 805 & 976 & & 42.66930 & -82.99601 & $3 N$ & $12 \mathrm{E}$ & 23 & 641 & 5027 & $\mathrm{D}$ & 1 \\
\hline
\end{tabular}


M. Le, MS Thesis, 2004

\begin{tabular}{|c|c|c|c|c|c|c|c|c|c|c|c|c|c|c|}
\hline Permit & Name & RGRC & DNDE & DRRV & DRB & Latitude & Longitude & Twn & Rng & Sec & $\mathrm{KB}$ & TD & Type & Omit \\
\hline 30125 & Manistee & & & & & 44.47894 & -85.89184 & $24 \mathrm{~N}$ & $13 W$ & 16 & 869 & 5635 & D & 1 \\
\hline 30502 & Manistee & 1836 & 1861 & 1986 & 2199 & 44.44261 & -86.04772 & $24 N$ & $14 W$ & 31 & 748 & 6360 & $\mathrm{D}$ & 1 \\
\hline 34277 & Manistee & 1945 & 1970 & 2107 & & 44.36233 & -86.07643 & $23 \mathrm{~N}$ & $15 W$ & 25 & 764 & 6631 & $\mathrm{D}$ & 1 \\
\hline 35882 & Manistee & 2177 & 2197 & 2366 & & 44.19115 & -86.03582 & $21 \mathrm{~N}$ & $14 W$ & 29 & 756 & 7400 & $\mathrm{D}$ & 1 \\
\hline 36588 & Manistee & & & & & 44.46253 & -86.02620 & $24 \mathrm{~N}$ & $14 \mathrm{~W}$ & 20 & 789 & 6265 & $\mathrm{D}$ & \\
\hline 37174 & Manistee & 1735 & 1755 & 1874 & & 44.37362 & -86.19537 & $23 N$ & $16 W$ & 25 & 761 & 6288 & $\bar{D}$ & 1 \\
\hline 15692 & Mason & & & & & 43.82567 & -86.40455 & $17 \mathrm{~N}$ & $18 W$ & 36 & 595 & 2083 & $\mathrm{D}$ & 1 \\
\hline 18905 & Mason & & & & & 43.83340 & -86.17481 & $17 \mathrm{~N}$ & $16 W$ & 25 & 725 & 7249 & $\mathrm{O}$ & 1 \\
\hline 21123 & Mason & & & & & 43.83899 & -86.16720 & $17 \mathrm{~N}$ & $16 W$ & 25 & 720 & 2337 & $\mathrm{OI}$ & 1 \\
\hline 21722 & Mason & & & & & 43.84214 & -86.42462 & $17 \mathrm{~N}$ & $18 W$ & 26 & 616 & 2088 & $\mathrm{D}$ & 1 \\
\hline 29503 & Mason & 2273 & 2278 & 2419 & & 43.86210 & -86.26686 & $17 \mathrm{~N}$ & $16 \mathrm{~W}$ & 18 & 718 & 6000 & $\mathrm{D}$ & 1 \\
\hline 32471 & Mason & 1913 & 1918 & 2046 & & 44.10186 & -86.38542 & $20 N$ & $17 W$ & 30 & 668 & 5480 & $\mathrm{D}$ & 1 \\
\hline 39984 & Mason & 2175 & 2180 & 2312 & & 44.00937 & -86.31203 & $19 \mathrm{~N}$ & $17 \mathrm{~W}$ & 26 & 679 & 7485 & $\mathrm{D}$ & 1 \\
\hline 40773 & Mason & 2271 & 2276 & 2424 & & 43.83304 & -86.18087 & $17 \mathrm{~N}$ & $16 W$ & 26 & 725 & 7200 & $D$ & 1 \\
\hline 25790 & Mecosta & & & & & 43.72218 & -85.41685 & $15 \mathrm{~N}$ & $9 W$ & 5 & 947 & 3569 & $\mathrm{D}$ & 1 \\
\hline 35259 & Mecosta & 3859 & 3884 & 4083 & 4238 & 43.61832 & -85.10234 & $14 N$ & $7 \mathrm{~W}$ & 12 & 1103 & 10175 & $\mathrm{D}$ & 1 \\
\hline 35259 & Mecosta & & & & & 43.61832 & -85.10234 & $14 \mathrm{~N}$ & $7 \mathrm{~W}$ & 12 & 1103 & 10175 & $D$ & \\
\hline 35426 & Mecosta & 3902 & 3927 & 4134 & 4290 & 43.79834 & -85.21474 & $16 \mathrm{~N}$ & $8 W$ & 12 & 1152 & 5100 & $\mathrm{GC}$ & 1 \\
\hline 36067 & Mecosta & 3969 & 3989 & 4198 & & 43.80564 & -85.32189 & $16 \mathrm{~N}$ & $8 W$ & 6 & 1192 & 8386 & $\mathrm{D}$ & 1 \\
\hline 36067 & Mecosta & & & & & 43.80564 & -85.32189 & $16 \mathrm{~N}$ & $8 W$ & 6 & 1192 & 8386 & $\mathrm{D}$ & \\
\hline 36187 & Mecosta & & & & & 43.79102 & -85.31133 & $16 \mathrm{~N}$ & $8 W$ & 7 & 1214 & 8380 & $D$ & \\
\hline 36283 & Mecosta & & & & & 43.79796 & -85.34081 & $16 \mathrm{~N}$ & $9 W$ & 12 & 1167 & 8215 & $\mathrm{D}$ & \\
\hline 36396 & Mecosta & & & & & 43.79025 & -85.21474 & $16 \mathrm{~N}$ & $8 W$ & 12 & 1130 & 5100 & $\mathrm{D}$ & \\
\hline 36455 & Mecosta & 3707 & 3727 & 3941 & & 43.79805 & -85.37634 & $16 \mathrm{~N}$ & $9 W$ & 10 & 1059 & 7975 & $\mathrm{D}$ & 2 \\
\hline 36455 & Mecosta & & & & & 43.79805 & -85.37634 & $16 \mathrm{~N}$ & $9 \mathrm{~W}$ & 10 & 1059 & 7975 & $\mathrm{D}$ & \\
\hline 36864 & Mecosta & 3882 & 3902 & 4118 & & 43.79003 & -85.34641 & $16 \mathrm{~N}$ & $9 W$ & 11 & 1154 & 8121 & $\mathrm{D}$ & 1 \\
\hline 36864 & Mecosta & & & & & 43.79003 & -85.34641 & $16 \mathrm{~N}$ & $9 W$ & 11 & 1154 & 8121 & $\mathrm{D}$ & \\
\hline 36890 & Mecosta & & & & & 43.77655 & -85.30730 & $16 \mathrm{~N}$ & $8 W$ & 18 & 1158 & 8264 & $\mathrm{D}$ & \\
\hline 36890 & Mecosta & & & & & 43.77655 & -85.30730 & $16 \mathrm{~N}$ & $8 W$ & 18 & 1158 & 8264 & $\mathrm{D}$ & \\
\hline 37188 & Mecosta & & & & & 43.80761 & -85.34541 & $16 \mathrm{~N}$ & $9 W$ & 2 & 1114 & 8085 & $\mathrm{D}$ & \\
\hline 37188 & Mecosta & & & & & 43.80761 & -85.34541 & $16 \mathrm{~N}$ & $9 W$ & 2 & 1114 & 8085 & $\mathrm{D}$ & \\
\hline 37723 & Mecosta & 3787 & 3807 & 3996 & 4156 & 43.66044 & -85.17749 & $15 \mathrm{~N}$ & $7 \mathrm{~W}$ & 29 & 1044 & 5006 & $\mathrm{D}$ & 3 \\
\hline
\end{tabular}


M. Le, MS Thesis, 2004

\begin{tabular}{|c|c|c|c|c|c|c|c|c|c|c|c|c|c|c|}
\hline Permit & Name & RGRC & DNDE & DRRV & DRB & Latitude & Longitude & Twn & Rng & Sec & KB & TD & Type & Omit \\
\hline 39713 & Mecosta & 3250 & 3270 & 3450 & 3566 & 43.53748 & -85.53870 & $13 N$ & $10 W$ & 8 & 944 & 8145 & $G$ & 1 \\
\hline 39727 & Mecosta & & & & & 43.50662 & -85.51820 & $13 N$ & $10 \mathrm{~W}$ & 21 & 963 & 8225 & $\mathrm{D}$ & \\
\hline 40215 & Mecosta & 3379 & 3399 & 3582 & 3702 & 43.58517 & -85.47877 & $14 N$ & $10 W$ & 23 & 991 & 8760 & $\mathrm{G}$ & 3 \\
\hline 40242 & Mecosta & & & & & 43.77926 & -85.46422 & $16 \mathrm{~N}$ & $10 W$ & 14 & 1084 & 9484 & $\mathrm{G}$ & \\
\hline 40242 & Mecosta & & & & & 43.77926 & -85.46422 & $16 \mathrm{~N}$ & $10 W$ & 14 & 1084 & 9484 & $\mathrm{G}$ & \\
\hline 40477 & Mecosta & 3517 & 3537 & 3745 & & 43.81168 & -85.42501 & $16 \mathrm{~N}$ & $9 W$ & 6 & 1024 & 9733 & $\mathrm{D}$ & 1 \\
\hline 40477 & Mecosta & & & & & 43.81168 & -85.42501 & $16 \mathrm{~N}$ & $9 W$ & 6 & 1024 & 9733 & $\mathrm{D}$ & \\
\hline 40543 & Mecosta & 3614 & 3634 & 3821 & 3999 & 43.64578 & -85.39360 & $15 \mathrm{~N}$ & $9 \mathrm{~W}$ & 33 & 1059 & 9313 & $\mathrm{D}$ & 6 \\
\hline 40682 & Mecosta & 3544 & 3564 & 3770 & & 43.79140 & -85.40383 & $16 \mathrm{~N}$ & $9 W$ & 8 & 979 & 9820 & $\mathrm{D}$ & 1 \\
\hline 40869 & Mecosta & & & & & 43.64547 & -85.42760 & $15 \mathrm{~N}$ & $9 W$ & 4 & 1059 & 10080 & $\mathrm{G}$ & \\
\hline 41010 & Mecosta & 3456 & 3476 & 3676 & & 43.74891 & -85.51469 & $16 \mathrm{~N}$ & $10 \mathrm{~W}$ & 28 & 1034 & 9325 & $D$ & 1 \\
\hline 41010 & Mecosta & & & & & 43.74891 & -85.51469 & $16 \mathrm{~N}$ & $10 W$ & 28 & 1034 & 9325 & $\mathrm{D}$ & \\
\hline 41116 & Mecosta & 3484 & 3504 & 3696 & 3854 & 43.68368 & -85.42729 & $15 N$ & $9 W$ & 19 & 1005 & 9268 & $\bar{G}$ & 1 \\
\hline 41116 & Mecosta & & & & & 43.68368 & -85.42729 & $15 \mathrm{~N}$ & $9 \mathrm{~W}$ & 19 & 1005 & 9268 & $\mathrm{G}$ & \\
\hline 41137 & Mecosta & & & & & 43.67512 & -85.42131 & $15 \mathrm{~N}$ & $9 W$ & 20 & 1064 & 9305 & $\mathrm{G}$ & \\
\hline 41137 & Mecosta & & & & & 43.67512 & -85.42131 & $15 \mathrm{~N}$ & $9 W$ & 20 & 1064 & 9305 & $\mathrm{G}$ & \\
\hline 41267 & Mecosta & 3834 & 3859 & 4021 & 4167 & 43.52705 & -85.16070 & $13 \mathrm{~N}$ & $7 \mathrm{~W}$ & 9 & 1213 & 9610 & $D$ & 1 \\
\hline 41267 & Mecosta & & & & & 43.52705 & -85.16070 & $13 \mathrm{~N}$ & $7 \mathrm{~W}$ & 9 & 1213 & 9610 & $D$ & \\
\hline 41440 & Mecosta & 3440 & 3460 & 3663 & & 43.78123 & -85.52195 & $16 \mathrm{~N}$ & $10 W$ & 16 & 1002 & 9325 & $\mathrm{G}$ & 1 \\
\hline 41440 & Mecosta & & & & & 43.78123 & -85.52195 & $16 \mathrm{~N}$ & $10 \mathrm{~W}$ & 16 & 1002 & 9325 & $\mathrm{G}$ & \\
\hline 42068 & Mecosta & & & & & 43.73453 & -85.41011 & $16 \mathrm{~N}$ & $9 \mathrm{~W}$ & 32 & 1025 & 9417 & $\mathrm{D}$ & \\
\hline 42314 & Mecosta & & & & & 43.76826 & -85.44467 & $16 \mathrm{~N}$ & $10 W$ & 24 & 1135 & 8439 & $\mathrm{G}$ & \\
\hline 42553 & Mecosta & 3504 & 3524 & 3727 & 3893 & 43.71597 & -85.42243 & $15 \mathrm{~N}$ & $9 W$ & 5 & 1022 & 9392 & $D$ & 1 \\
\hline 42553 & Mecosta & & & & & 43.71597 & -85.42243 & $15 \mathrm{~N}$ & $9 \mathrm{~W}$ & 5 & 1022 & 9392 & $\mathrm{D}$ & \\
\hline 42685 & Mecosta & & & & & 43.73182 & -85.40591 & $16 \mathrm{~N}$ & $9 W$ & 32 & 1025 & 9703 & $\mathrm{GC}$ & \\
\hline 42817 & Mecosta & 3413 & 3433 & 3627 & 3789 & 43.65093 & -85.46112 & $15 \mathrm{~N}$ & $10 \mathrm{~W}$ & 36 & 947 & 8960 & $G$ & 2 \\
\hline 42907 & Mecosta & 3510 & 3530 & 3734 & & 43.77446 & -85.44750 & $16 \mathrm{~N}$ & $10 \mathrm{~W}$ & 13 & 1069 & 9510 & $D$ & 1 \\
\hline 42907 & Mecosta & & & & & 43.77446 & -85.44750 & $16 \mathrm{~N}$ & $10 W$ & 13 & 1069 & 9510 & $\mathrm{D}$ & \\
\hline 43106 & Mecosta & & & & & 43.68905 & -85.42069 & $15 \mathrm{~N}$ & $9 W$ & 17 & 1010 & 7320 & $\mathrm{D}$ & \\
\hline 23849 & Midland & 3365 & 3390 & 3606 & & 43.50800 & -84.43211 & $13 \mathrm{~N}$ & $1 \mathrm{~W}$ & 21 & 695 & $9514^{*}$ & $\mathrm{D}$ & 1 \\
\hline 30378 & Midland & 3649 & 3709 & 3989 & 4051 & 43.71877 & -84.17845 & $15 \mathrm{~N}$ & $2 \mathrm{E}$ & 12 & 676 & 5264 & $D$ & 3 \\
\hline 37150 & Midland & 3791 & 3841 & 4050 & 4234 & 43.77185 & -84.52784 & $16 \mathrm{~N}$ & $2 W$ & 15 & 735 & 5050 & $D$ & 1 \\
\hline
\end{tabular}


M. Le, MS Thesis, 2004

\begin{tabular}{|c|c|c|c|c|c|c|c|c|c|c|c|c|c|c|}
\hline Permit & Name & RGRC & DNDE & DRRV & DRB & Latitude & Longitude & Twn & Rng & Sec & $\mathrm{KB}$ & TD & Type & Omit \\
\hline 20389 & Missaukee & & & & & 44.26330 & -85.00981 & $22 \mathrm{~N}$ & $6 W$ & 35 & 1186 & 5223 & D & 2 \\
\hline 24501 & Missaukee & & & & & 44.26350 & -85.09163 & $22 \mathrm{~N}$ & $6 \mathrm{~W}$ & 31 & 1207 & 5642 & $\mathrm{D}$ & 1 \\
\hline 27105 & Missaukee & & & & & 44.25216 & -84.99458 & $22 \mathrm{~N}$ & $6 W$ & 35 & 1170 & 5228 & $\mathrm{D}$ & 1 \\
\hline 31479 & Missaukee & & & & & 44.26795 & -85.08786 & $22 \mathrm{~N}$ & $6 W$ & 30 & 1197 & 5215 & $\mathrm{WI}$ & 1 \\
\hline 31967 & Missaukee & & & & & 44.26074 & -85.08773 & $22 \mathrm{~N}$ & $6 \mathrm{~W}$ & 31 & 1207 & 5261 & $\mathrm{O}$ & 1 \\
\hline 32017 & Missaukee & & & & & 44.26812 & -85.09791 & $22 \mathrm{~N}$ & $7 \mathrm{~W}$ & 25 & 1207 & 5200 & WI & 2 \\
\hline 32092 & Missaukee & & & & & 44.26423 & -85.08269 & $22 \mathrm{~N}$ & $6 \mathrm{~W}$ & 31 & 1198 & 5220 & $\mathrm{O}$ & 5 \\
\hline 32132 & Missaukee & & & & & 44.26433 & -85.08774 & $22 \mathrm{~N}$ & $6 \mathrm{~W}$ & 31 & 1208 & 5233 & $\mathrm{O}$ & 2 \\
\hline 32138 & Missaukee & & & & & 44.26072 & -85.09292 & $22 \mathrm{~N}$ & $6 W$ & 31 & 1209 & 5265 & $\mathrm{O}$ & 2 \\
\hline 32139 & Missaukee & & & & & 44.26451 & -85.09798 & $22 \mathrm{~N}$ & $7 \mathrm{~W}$ & 36 & 1207 & 5232 & $\mathrm{O}$ & 2 \\
\hline 32163 & Missaukee & & & & & 44.26443 & -85.09289 & $22 \mathrm{~N}$ & $6 \mathrm{~W}$ & 31 & 1210 & 5215 & $\mathrm{WI}$ & 2 \\
\hline 32174 & Missaukee & & & & & 44.27173 & -85.10311 & $22 \mathrm{~N}$ & $7 \mathrm{~W}$ & 25 & 1209 & 5245 & WI & 2 \\
\hline 32175 & Missaukee & & & & & 44.26816 & -85.10311 & $22 \mathrm{~N}$ & $7 \mathrm{~W}$ & 25 & 1213 & 5307 & $\mathrm{O}$ & 2 \\
\hline 32181 & Missaukee & 3986 & 4036 & 4241 & 4482 & 44.22732 & -85.24349 & $21 \mathrm{~N}$ & $8 W$ & 11 & 1241 & 5330 & $\mathrm{D}$ & 1 \\
\hline 32189 & Missaukee & & & & & 44.25712 & -85.08769 & $22 \mathrm{~N}$ & $6 W$ & 31 & 1209 & 5500 & $\mathrm{O}$ & 2 \\
\hline 32221 & Missaukee & & & & & 44.26745 & -85.09288 & $22 \mathrm{~N}$ & $6 W$ & 30 & 1199 & 5210 & $\mathrm{O}$ & 2 \\
\hline 32223 & Missaukee & & & & & 44.26104 & -85.09798 & $22 \mathrm{~N}$ & $7 \mathrm{~W}$ & 36 & 1210 & 5215 & $\mathrm{WI}$ & 2 \\
\hline 32233 & Missaukee & 3851 & 3906 & 4110 & 4312 & 44.27173 & -85.09796 & $22 \mathrm{~N}$ & $7 \mathrm{~W}$ & 25 & 1203 & 5218 & $\mathrm{O}$ & 2 \\
\hline 32351 & Missaukee & & & & & 44.27017 & -85.09285 & $22 \mathrm{~N}$ & $6 \mathrm{~W}$ & 30 & 1200 & 5250 & WI & 2 \\
\hline 32421 & Missaukee & & & & & 44.26457 & -85.10310 & $22 \mathrm{~N}$ & $7 \mathrm{~W}$ & 36 & 1210 & 5256 & WI & 2 \\
\hline 32422 & Missaukee & & & & & 44.26104 & -85.10310 & $22 \mathrm{~N}$ & $7 \mathrm{~W}$ & 36 & 1215 & 5226 & $\mathrm{O}$ & 2 \\
\hline 32584 & Missaukee & & & & & 44.26821 & -85.10762 & $22 \mathrm{~N}$ & $7 \mathrm{~W}$ & 25 & 1203 & 5264 & $\mathrm{O}$ & 2 \\
\hline 32636 & Missaukee & & & & & 44.27043 & -85.10609 & $22 \mathrm{~N}$ & $7 \mathrm{~W}$ & 25 & 1208 & 5211 & $\mathrm{O}$ & 2 \\
\hline 32642 & Missaukee & & & & & 44.26782 & -85.09169 & $22 \mathrm{~N}$ & $6 \mathrm{~W}$ & 30 & 1193 & 4155 & $\mathrm{O}$ & 2 \\
\hline 32659 & Missaukee & & & & & 44.25294 & -85.01535 & $22 \mathrm{~N}$ & $6 \mathrm{~W}$ & 34 & 1192 & 5260 & $\mathrm{D}$ & 2 \\
\hline 32673 & Missaukee & & & & & 44.27172 & -85.11334 & $22 \mathrm{~N}$ & $7 \mathrm{~W}$ & 25 & 1212 & 5213 & $\mathrm{BD}$ & 2 \\
\hline 32697 & \begin{tabular}{|l|} 
Missaukee \\
\end{tabular} & & & & & 44.26463 & -85.10814 & $22 \mathrm{~N}$ & $7 \mathrm{~W}$ & 36 & 1209 & 3486 & $\mathrm{O}$ & 2 \\
\hline 32715 & Missaukee & & & & & 44.26995 & -85.10815 & $22 \mathrm{~N}$ & $7 \mathrm{~W}$ & 25 & 1205 & 3870 & $\mathrm{O}$ & 2 \\
\hline 33016 & Missaukee & & & & & 44.25204 & -84.98455 & $22 \mathrm{~N}$ & $6 W$ & 36 & 1165 & 3811 & BD & 2 \\
\hline 33046 & Missaukee & & & & & 44.26995 & -85.10777 & $22 \mathrm{~N}$ & $7 \mathrm{~W}$ & 25 & 1203 & 3495 & $\mathrm{O}$ & 2 \\
\hline 33413 & Missaukee & 3862 & 3917 & 4126 & 4335 & 44.25744 & -85.09799 & $22 \mathrm{~N}$ & $7 \mathrm{~W}$ & 36 & 1204 & 5225 & $\mathrm{O}$ & 2 \\
\hline 33758 & Missaukee & 3976 & 4026 & 4236 & 4426 & 44.28144 & -85.17628 & $22 \mathrm{~N}$ & $7 \mathrm{~W}$ & 20 & 1251 & 5320 & $\mathrm{D}$ & 2 \\
\hline
\end{tabular}


M. Le, MS Thesis, 2004

\begin{tabular}{|c|c|c|c|c|c|c|c|c|c|c|c|c|c|c|}
\hline Permit & Name & RGRC & DNDE & DRRV & DRB & Latitude & Longitude & Twn & Rng & Sec & KB & TD & Type & Omit \\
\hline 33760 & Missaukee & 3825 & 3885 & 4125 & 4355 & 44.26319 & -85.00469 & $22 N$ & $6 W$ & 35 & 1190 & 5280 & 0 & 1 \\
\hline 33819 & Missaukee & & & & & 44.25712 & -85.09295 & $22 \mathrm{~N}$ & $6 \mathrm{~W}$ & 31 & 1208 & 5225 & $\mathrm{O}$ & 2 \\
\hline 34000 & Missaukee & & & & & 44.25744 & -85.10310 & $22 \mathrm{~N}$ & $7 \mathrm{~W}$ & 36 & 1197 & 5230 & $\mathrm{WI}$ & 2 \\
\hline 34005 & Missaukee & & & & & 44.26103 & -85.10814 & $22 \mathrm{~N}$ & $7 \mathrm{~W}$ & 36 & 1211 & 5230 & $\mathrm{WI}$ & 2 \\
\hline 34078 & Missaukee & & & & & 44.49063 & -85.08097 & $24 \mathrm{~N}$ & $6 W$ & 7 & 1289 & 9300 & $\mathrm{D}$ & 2 \\
\hline 34293 & Missaukee & & & & & 44.25744 & -85.10814 & $22 \mathrm{~N}$ & $7 \mathrm{~W}$ & 36 & 1198 & 5225 & $\mathrm{O}$ & 2 \\
\hline 34357 & Missaukee & & & & & 44.26270 & -85.07707 & $22 \mathrm{~N}$ & $6 \mathrm{~W}$ & 31 & 1205 & 0 & $\mathrm{D}$ & 2 \\
\hline 34376 & Missaukee & & & & & 44.27762 & -85.09120 & $22 \mathrm{~N}$ & $6 \mathrm{~W}$ & 30 & 1232 & 14713 & $\mathrm{D}$ & 2 \\
\hline 34459 & Missaukee & 3992 & 4052 & 4284 & 4500 & 44.29041 & -85.02561 & $22 \mathrm{~N}$ & $6 \mathrm{~W}$ & 22 & 1277 & 5380 & $\mathrm{D}$ & 1 \\
\hline 34511 & Missaukee & 3930 & 3980 & 4201 & 4409 & 44.26195 & -85.15658 & $22 \mathrm{~N}$ & $7 \mathrm{~W}$ & 33 & 1210 & 10812 & $\mathrm{D}$ & 1 \\
\hline 34606 & Missaukee & 3866 & 3926 & 4128 & 4352 & 44.25184 & -84.99678 & $22 \mathrm{~N}$ & $6 W$ & 35 & 1177 & 10970 & $\mathrm{D}$ & 1 \\
\hline 34606 & Missaukee & & & & & 44.25184 & -84.99678 & $22 \mathrm{~N}$ & $6 W$ & 35 & 1177 & 10970 & $\mathrm{D}$ & \\
\hline 34981 & Missaukee & & & & & 44.25381 & -85.09298 & $22 \mathrm{~N}$ & $6 \mathrm{~W}$ & 31 & 1211 & 4417 & $\mathrm{O}$ & \\
\hline 36173 & Missaukee & & & & & 44.18481 & -85.30207 & $21 \mathrm{~N}$ & $8 W$ & 29 & 1446 & 11650 & $\mathrm{O}$ & \\
\hline 36173 & Missaukee & & & & & 44.18481 & -85.30207 & $21 \mathrm{~N}$ & $8 W$ & 29 & 1446 & 11650 & $\mathrm{O}$ & \\
\hline 36325 & Missaukee & & & & & 44.17743 & -85.07876 & $21 \mathrm{~N}$ & $6 W$ & 31 & 1193 & 5077 & $\mathrm{D}$ & \\
\hline 36778 & Missaukee & 4024 & 4074 & 4270 & & 44.18530 & -85.30841 & $21 \mathrm{~N}$ & $8 W$ & 29 & 1398 & 5400 & $\mathrm{D}$ & 2 \\
\hline 36940 & Missaukee & 4006 & 4056 & 4292 & 4491 & 44.20222 & -85.19768 & $21 \mathrm{~N}$ & $7 \mathrm{~W}$ & 19 & 1298 & 5380 & $\mathrm{O}$ & 1 \\
\hline 37137 & Missaukee & & & & & 44.19828 & -85.19750 & $21 \mathrm{~N}$ & $7 \mathrm{~W}$ & 19 & 1252 & 5340 & $\mathrm{O}$ & \\
\hline 37298 & Missaukee & 4000 & 4050 & 4258 & 4499 & 44.21097 & -85.28337 & $21 \mathrm{~N}$ & $8 W$ & 16 & 1344 & 5334 & $D$ & 2 \\
\hline 38462 & Missaukee & & & & & 44.25743 & -85.11323 & $22 \mathrm{~N}$ & $7 \mathrm{~W}$ & 36 & 1206 & 5238 & $D$ & \\
\hline 38506 & Missaukee & & & & & 44.20008 & -85.31372 & $21 \mathrm{~N}$ & $8 W$ & 20 & 1461 & 5500 & $\mathrm{D}$ & \\
\hline 39578 & Missaukee & 3792 & 3842 & 4047 & 4232 & 44.31902 & -85.19246 & $22 \mathrm{~N}$ & $7 \mathrm{~W}$ & 8 & 1254 & 5219 & $\mathrm{D}$ & 1 \\
\hline 39725 & Missaukee & 3688 & 3738 & 3962 & 4145 & 44.39126 & -85.18978 & $23 \mathrm{~N}$ & $7 \mathrm{~W}$ & 17 & 1219 & 11650 & $\mathrm{D}$ & 1 \\
\hline 40314 & Missaukee & 3180 & 3260 & 3501 & & 44.49009 & -84.86880 & $24 \mathrm{~N}$ & $5 W$ & 12 & 1328 & 11756 & $\mathrm{O}$ & 1 \\
\hline 40605 & Missaukee & & & & & 44.19807 & -85.19155 & $21 \mathrm{~N}$ & $7 \mathrm{~W}$ & 20 & 1251 & 11980 & $\mathrm{D}$ & \\
\hline 41179 & \begin{tabular}{|l|} 
Missaukee \\
\end{tabular} & 3942 & 3997 & 4202 & 4409 & 44.17366 & -85.07611 & $21 \mathrm{~N}$ & $6 \mathrm{~W}$ & 31 & 1219 & 12030 & GC & 1 \\
\hline 41179 & Missaukee & & & & & 44.17366 & -85.07611 & $21 \mathrm{~N}$ & $6 W$ & 31 & 1219 & 12030 & $\mathrm{GC}$ & \\
\hline 41717 & Missaukee & & & & & 44.18114 & -85.08386 & $21 \mathrm{~N}$ & $6 W$ & 30 & 1189 & 11745 & $\mathrm{G}$ & \\
\hline 41830 & Missaukee & 3955 & 4005 & 4240 & 4447 & 44.20910 & -85.15002 & $21 \mathrm{~N}$ & $7 \mathrm{~W}$ & 15 & 1234 & 11970 & $\mathrm{G}$ & 1 \\
\hline 42691 & Missaukee & & & & & 44.20942 & -85.15782 & $21 \mathrm{~N}$ & $7 \mathrm{~W}$ & 16 & 1246 & 10920 & $\mathrm{D}$ & \\
\hline 43617 & Missaukee & & & & & 44.17249 & -85.23750 & $21 \mathrm{~N}$ & $8 W$ & 35 & 1385 & 11700 & $\mathrm{D}$ & \\
\hline
\end{tabular}


M. Le, MS Thesis, 2004

\begin{tabular}{|c|c|c|c|c|c|c|c|c|c|c|c|c|c|c|}
\hline Permit & Name & RGRC & DNDE & DRRV & DRB & Latitude & Longitude & Twn & Rng & Sec & $\mathrm{KB}$ & TD & Type & Omit \\
\hline 35948 & Monroe & & & & & 41.90265 & -83.55255 & $7 S$ & $7 E$ & 1 & 646 & 3506 & D & \\
\hline 37906 & Monroe & & 66 & 171 & & 42.00728 & -83.74864 & $5 S$ & $6 \mathrm{E}$ & 32 & 690 & 3273 & $\mathrm{D}$ & 1 \\
\hline 24011 & Montcalm & & & & & 43.35485 & -84.93167 & $11 \mathrm{~N}$ & $5 W$ & 8 & 965 & 3496 & $\mathrm{D}$ & 2 \\
\hline 30027 & Montcalm & 3202 & 3227 & 3365 & 3496 & 43.23288 & -85.11194 & $10 \mathrm{~N}$ & $7 \mathrm{~W}$ & 26 & 875 & 4173 & $\mathrm{D}$ & 1 \\
\hline 30107 & Montcalm & 3453 & 3478 & 3653 & 3803 & 43.43437 & -84.94908 & $12 \mathrm{~N}$ & $5 W$ & 18 & 905 & 4736 & $\mathrm{D}$ & 1 \\
\hline 30147 & Montcalm & 3386 & 3411 & 3551 & 3691 & 43.30777 & -85.07321 & $11 \mathrm{~N}$ & $6 W$ & 30 & 965 & 4494 & $\mathrm{D}$ & 1 \\
\hline 33611 & Montcalm & 3083 & 3098 & 3245 & & 43.15287 & -84.92448 & $9 \mathrm{~N}$ & $5 W$ & 20 & 794 & 3275 & $\mathrm{D}$ & 1 \\
\hline 37674 & Montcalm & & & & & 43.45969 & -84.99249 & $12 \mathrm{~N}$ & $6 W$ & 2 & 998 & 4645 & $\mathrm{O}$ & \\
\hline 37799 & Montcalm & & & & & 43.36747 & -85.14046 & $11 \mathrm{~N}$ & $7 \mathrm{~W}$ & 3 & 949 & 3505 & $\mathrm{D}$ & \\
\hline 39483 & Montcalm & & & & & 43.31138 & -84.94873 & $11 \mathrm{~N}$ & $5 W$ & 30 & 878 & 3343 & $\mathrm{O}$ & \\
\hline 39779 & Montcalm & 3237 & 3252 & 3420 & 3558 & 43.43700 & -85.44029 & $12 \mathrm{~N}$ & $9 \mathrm{~W}$ & 18 & 927 & 8420 & $\mathrm{D}$ & 1 \\
\hline 39779 & Montcalm & & & & & 43.43700 & -85.44029 & $12 \mathrm{~N}$ & $9 W$ & 18 & 927 & 8420 & $\mathrm{D}$ & \\
\hline 41480 & Montcalm & 3251 & 3276 & 3407 & & 43.26139 & -85.00030 & $10 \mathrm{~N}$ & $6 W$ & 15 & 850 & 3435 & $\mathrm{D}$ & 1 \\
\hline 34648 & Montmorency & 2295 & 2390 & 2543 & & 44.91434 & -84.18036 & $29 N$ & $2 E$ & 10 & 1216 & 8455 & $\mathrm{D}$ & 2 \\
\hline 40601 & Montmorency & 1536 & 1631 & 1782 & & 44.99981 & -84.05682 & $30 \mathrm{~N}$ & $3 E$ & 15 & 929 & 894 & $\mathrm{G}$ & 1 \\
\hline 41036 & Montmorency & 1477 & 1577 & 1706 & & 44.92937 & -83.95456 & $29 N$ & $4 \mathrm{E}$ & 4 & 820 & 8300 & $\mathrm{D}$ & 1 \\
\hline 18666 & Muskegon & & & & & 43.42468 & -86.37202 & $12 \mathrm{~N}$ & $17 \mathrm{~W}$ & 20 & 666 & 4858 & $\mathrm{D}$ & 1 \\
\hline 23010 & Muskegon & & 2035 & 2080 & 2179 & 43.12057 & -86.21192 & $9 \mathrm{~N}$ & $16 \mathrm{~W}$ & 33 & 620 & 3636 & $\mathrm{D}$ & 1 \\
\hline 26662 & Newaygo & 2646 & 2656 & 2817 & & 43.67446 & -86.01056 & $15 \mathrm{~N}$ & $14 W$ & 20 & 829 & 8215 & $\mathrm{D}$ & 1 \\
\hline 26662 & Newaygo & & & & & 43.67446 & -86.01056 & $15 \mathrm{~N}$ & $14 \mathrm{~W}$ & 20 & 829 & 8215 & $\mathrm{D}$ & 1 \\
\hline 35311 & Newaygo & 3466 & 3481 & 3683 & & 43.74731 & -85.63168 & $16 \mathrm{~N}$ & $11 \mathrm{~W}$ & 28 & 1078 & 7954 & $\mathrm{D}$ & 1 \\
\hline 36622 & Newaygo & & & & & 43.61961 & -85.64392 & $14 N$ & $11 \mathrm{~W}$ & 8 & 1081 & 8639 & $G$ & \\
\hline 38561 & Newaygo & 3013 & 3023 & 3212 & & 43.53129 & -85.75035 & $13 \mathrm{~N}$ & $12 W$ & 9 & 888 & 3400 & $\mathrm{D}$ & 1 \\
\hline 38567 & Newaygo & & & & & 43.66809 & -85.64616 & $15 \mathrm{~N}$ & $11 \mathrm{~W}$ & 29 & 1092 & 8300 & $\mathrm{G}$ & \\
\hline 39166 & Newaygo & 3351 & 3366 & 3556 & 3734 & 43.67247 & -85.65116 & $15 \mathrm{~N}$ & $11 \mathrm{~W}$ & 20 & 1092 & 8744 & $G$ & 1 \\
\hline 39443 & Newaygo & & & & & 43.66080 & -85.73744 & $15 \mathrm{~N}$ & $12 W$ & 27 & 935 & 8300 & $\mathrm{D}$ & \\
\hline 39675 & Newaygo & & & & & 43.67990 & -85.65167 & $15 \mathrm{~N}$ & $11 \mathrm{~W}$ & 20 & 1065 & 8250 & $\mathrm{D}$ & \\
\hline 39856 & Newaygo & & & & & 43.65824 & -85.63140 & $15 \mathrm{~N}$ & $11 \mathrm{~W}$ & 28 & 1093 & 0 & $\mathrm{GC}$ & \\
\hline 39856 & Newaygo & & & & & 43.65824 & -85.63140 & $15 \mathrm{~N}$ & $11 \mathrm{~W}$ & 28 & 1093 & 0 & $\mathrm{GC}$ & \\
\hline 39914 & Newaygo & & & & & 43.62930 & -86.00105 & $14 \mathrm{~N}$ & $14 W$ & 5 & 850 & 6980 & $G$ & \\
\hline 39916 & Newaygo & & & & & 43.65451 & -85.63521 & $15 \mathrm{~N}$ & $11 \mathrm{~W}$ & 33 & 1088 & 9375 & $\mathrm{G}$ & \\
\hline 39952 & Newaygo & 3195 & 3205 & 3394 & 3481 & 43.54272 & -85.62049 & $13 \mathrm{~N}$ & $11 \mathrm{~W}$ & 3 & 977 & 8109 & $\mathrm{D}$ & 1 \\
\hline
\end{tabular}


M. Le, MS Thesis, 2004

\begin{tabular}{|c|c|c|c|c|c|c|c|c|c|c|c|c|c|c|}
\hline Permit & Name & RGRC & DNDE & DRRV & DRB & Latitude & Longitude & Twn & Rng & Sec & KB & TD & Type & Omit \\
\hline 39992 & Newaygo & 2857 & 2867 & 3027 & 3113 & 43.35906 & -85.66859 & $11 \mathrm{~N}$ & $11 \mathrm{~W}$ & 7 & 826 & 7080 & $G$ & 1 \\
\hline 41628 & Newaygo & & & & & 43.68272 & -85.62248 & $15 \mathrm{~N}$ & $11 \mathrm{~W}$ & 21 & 1208 & 9248 & $\mathrm{GC}$ & \\
\hline 41714 & Newaygo & & & & & 43.38254 & -85.62368 & $12 \mathrm{~N}$ & $11 \mathrm{~W}$ & 33 & 988 & 7376 & $\mathrm{G}$ & \\
\hline 41892 & Newaygo & 2955 & 2965 & 3130 & & 43.40230 & -85.66583 & $12 \mathrm{~N}$ & $11 \mathrm{~W}$ & 30 & 891 & 7320 & $\mathrm{D}$ & 3 \\
\hline 42856 & Newaygo & 3073 & 3083 & 3246 & 3333 & 43.37021 & -85.61846 & $11 \mathrm{~N}$ & $11 \mathrm{~W}$ & 3 & 989 & 7200 & $\mathrm{G}$ & 3 \\
\hline 44217 & Newaygo & 3028 & 3038 & 3238 & & 43.63229 & -85.77187 & $14 N$ & $12 W$ & 5 & 942 & 7892 & $\mathrm{D}$ & 1 \\
\hline 28258 & Oakland & & 1647 & 1815 & 1787 & 42.70661 & -83.48281 & $4 \mathrm{~N}$ & $8 \mathrm{E}$ & 35 & 1048 & 6500 & $\mathrm{D}$ & 4 \\
\hline 36303 & Oakland & & 1030 & 1215 & & 42.52880 & -83.43946 & $2 \mathrm{~N}$ & $8 \mathrm{E}$ & 36 & 975 & 5610 & $\mathrm{D}$ & 1 \\
\hline 14081 & Oceana & & & & & 43.81470 & -86.39418 & $16 \mathrm{~N}$ & $17 W$ & 6 & 628 & 2235 & $\mathrm{O}$ & 3 \\
\hline 14084 & Oceana & & & & & 43.81853 & -86.39926 & $16 \mathrm{~N}$ & $18 W$ & 1 & 615 & 2094 & $\mathrm{O}$ & 2 \\
\hline 14141 & Oceana & & & & & 43.81289 & -86.38689 & $16 \mathrm{~N}$ & $17 \mathrm{~W}$ & 6 & 665 & 2175 & $\mathrm{O}$ & 2 \\
\hline 14143 & Oceana & & & & & 43.81289 & -86.39671 & $16 \mathrm{~N}$ & $17 W$ & 6 & 623 & 2092 & $\mathrm{O}$ & 2 \\
\hline 14256 & Oceana & & & & & 43.80753 & -86.38439 & $16 \mathrm{~N}$ & $17 W$ & 6 & 665 & 2139 & $\mathrm{O}$ & 1 \\
\hline 14258 & Oceana & & & & & 43.80568 & -86.39189 & $16 \mathrm{~N}$ & $17 W$ & 6 & 642 & 2117 & $\mathrm{O}$ & 1 \\
\hline 14268 & Oceana & & & & & 43.81134 & -86.39929 & $16 \mathrm{~N}$ & $18 W$ & 1 & 613 & 2089 & $\mathrm{O}$ & 1 \\
\hline 14272 & Oceana & & & & & 43.80747 & -86.39430 & $16 \mathrm{~N}$ & $17 \mathrm{~W}$ & 6 & 634 & 2108 & $\mathrm{O}$ & 1 \\
\hline 14273 & Oceana & & & & & 43.80571 & -86.38689 & $16 \mathrm{~N}$ & $17 \mathrm{~W}$ & 6 & 677 & 2270 & $\mathrm{O}$ & 1 \\
\hline 14274 & Oceana & & & & & 43.81109 & -86.39424 & $16 \mathrm{~N}$ & $17 W$ & 6 & 632 & 2106 & $\mathrm{O}$ & 3 \\
\hline 14338 & Oceana & & & & & 43.80760 & -86.39932 & $16 \mathrm{~N}$ & $18 \mathrm{~W}$ & 1 & 618 & 2092 & $\mathrm{O}$ & 1 \\
\hline 14341 & Oceana & & & & & 43.80389 & -86.38961 & $16 \mathrm{~N}$ & $17 \mathrm{~W}$ & 7 & 665 & 2133 & $\mathrm{O}$ & 2 \\
\hline 14342 & Oceana & & & & & 43.80386 & -86.39437 & $16 \mathrm{~N}$ & $17 \mathrm{~W}$ & 7 & 637 & 2111 & $\mathrm{O}$ & 3 \\
\hline 14372 & Oceana & & & & & 43.80224 & -86.38673 & $16 \mathrm{~N}$ & $17 \mathrm{~W}$ & 7 & 664 & 2138 & $\mathrm{O}$ & 4 \\
\hline 14399 & Oceana & & & & & 43.81864 & -86.41933 & $16 \mathrm{~N}$ & $18 \mathrm{~W}$ & 2 & 625 & 2112 & $\mathrm{O}$ & 5 \\
\hline 14411 & Oceana & & & & & 43.80574 & -86.38212 & $16 \mathrm{~N}$ & $17 \mathrm{~W}$ & 6 & 654 & \begin{tabular}{|l|}
2127 \\
\end{tabular} & $\mathrm{O}$ & 1 \\
\hline 14412 & Oceana & & & & & 43.80928 & -86.39677 & $16 \mathrm{~N}$ & $17 \mathrm{~W}$ & 6 & 628 & 0 & $\mathrm{O}$ & 1 \\
\hline 14416 & Oceana & & & & & 43.80392 & -86.38461 & $16 \mathrm{~N}$ & $17 \mathrm{~W}$ & 7 & 655 & 2129 & $\mathrm{O}$ & 4 \\
\hline 14457 & Oceana & & & & & 43.80213 & -86.38216 & $16 \mathrm{~N}$ & $17 \mathrm{~W}$ & 7 & 641 & 2115 & $\mathrm{O}$ & 1 \\
\hline 14459 & Oceana & & & & & 43.81864 & -86.42113 & $16 \mathrm{~N}$ & $18 W$ & 2 & 631 & 2146 & $\mathrm{D}$ & 1 \\
\hline 14460 & Oceana & & & & & 43.80565 & -86.39683 & $16 \mathrm{~N}$ & $17 \mathrm{~W}$ & 6 & 628 & 2102 & $\mathrm{O}$ & 1 \\
\hline 14461 & Oceana & & & & & 43.80928 & -86.38208 & $16 \mathrm{~N}$ & $17 \mathrm{~W}$ & 6 & 663 & 2137 & $\mathrm{O}$ & 1 \\
\hline 14477 & Oceana & & & & & 43.80395 & -86.37964 & $16 \mathrm{~N}$ & $17 \mathrm{~W}$ & 7 & 642 & 2116 & $\mathrm{O}$ & 1 \\
\hline 14510 & Oceana & & & & & 43.80756 & -86.37960 & $16 \mathrm{~N}$ & $17 \mathrm{~W}$ & 6 & 650 & 2124 & $\mathrm{O}$ & 2 \\
\hline
\end{tabular}


M. Le, MS Thesis, 2004

\begin{tabular}{|c|c|c|c|c|c|c|c|c|c|c|c|c|c|c|}
\hline Permit & Name & RGRC & DNDE & DRRV & DRB & Latitude & Longitude & Twn & Rng & Sec & KB & TD & Type & Omit \\
\hline 14550 & Oceana & & & & & 43.80034 & -86.38461 & $16 \mathrm{~N}$ & $17 \mathrm{~W}$ & 7 & 644 & 2117 & 0 & 1 \\
\hline 14552 & Oceana & & & & & 43.80582 & -86.40183 & $16 \mathrm{~N}$ & $18 W$ & 1 & 614 & 2085 & $\mathrm{O}$ & 1 \\
\hline 14581 & Oceana & & & & & 43.80575 & -86.37712 & $16 \mathrm{~N}$ & $17 \mathrm{~W}$ & 5 & 641 & 2115 & $\mathrm{O}$ & 2 \\
\hline 14582 & Oceana & & & & & 43.80034 & -86.37975 & $16 \mathrm{~N}$ & $17 \mathrm{~W}$ & 7 & 645 & 2119 & $\mathrm{O}$ & 1 \\
\hline 14593 & Oceana & & & & & 43.80952 & -86.40180 & $16 \mathrm{~N}$ & $18 \mathrm{~W}$ & 1 & 605 & 2079 & $\mathrm{O}$ & 3 \\
\hline 14629 & Oceana & & & & & 43.80765 & -86.40430 & $16 \mathrm{~N}$ & $18 W$ & 1 & 606 & 2080 & $\mathrm{O}$ & 3 \\
\hline 14630 & Oceana & & & & & 43.80214 & -86.37716 & $16 \mathrm{~N}$ & $17 \mathrm{~W}$ & 8 & 613 & 2087 & $\mathrm{O}$ & 1 \\
\hline 14677 & Oceana & & & & & 43.81314 & -86.40179 & $16 \mathrm{~N}$ & $18 W$ & 1 & 609 & 2085 & $\mathrm{O}$ & 1 \\
\hline 14688 & Oceana & & & & & 43.80398 & -86.39935 & $16 \mathrm{~N}$ & $18 W$ & 12 & 623 & 2097 & $\mathrm{O}$ & 1 \\
\hline 14718 & Oceana & & & & & 43.80208 & -86.39165 & $16 \mathrm{~N}$ & $17 \mathrm{~W}$ & 7 & 645 & 0 & $\mathrm{D}$ & 1 \\
\hline 14730 & Oceana & & & & & 43.80034 & -86.38961 & $16 \mathrm{~N}$ & $17 \mathrm{~W}$ & 7 & 672 & 2195 & $\mathrm{O}$ & 1 \\
\hline 14801 & Oceana & & & & & 43.81134 & -86.40430 & $16 \mathrm{~N}$ & $18 W$ & 1 & 604 & 2077 & $\mathrm{O}$ & 1 \\
\hline 14825 & Oceana & & & & & 43.80404 & -86.40447 & $16 \mathrm{~N}$ & $18 W$ & 12 & 607 & 2081 & $\mathrm{O}$ & 1 \\
\hline 14876 & Oceana & & & & & 43.80020 & -86.37468 & $16 \mathrm{~N}$ & $17 W$ & 8 & 644 & 2149 & $\mathrm{O}$ & 1 \\
\hline 14888 & Oceana & & & & & 43.80392 & -86.37464 & $16 \mathrm{~N}$ & $17 \mathrm{~W}$ & 8 & 616 & 2090 & $\mathrm{O}$ & 1 \\
\hline 14948 & Oceana & & & & & 43.80912 & -86.37709 & $16 \mathrm{~N}$ & $17 \mathrm{~W}$ & 5 & 661 & 2135 & $\mathrm{O}$ & 1 \\
\hline 14983 & Oceana & & & & & 43.80952 & -86.40679 & $16 \mathrm{~N}$ & $18 \mathrm{~W}$ & 1 & 600 & 2074 & $\mathrm{O}$ & 1 \\
\hline 14984 & Oceana & & & & & 43.80753 & -86.37460 & $16 \mathrm{~N}$ & $17 \mathrm{~W}$ & 5 & 645 & 2118 & $\mathrm{O}$ & 1 \\
\hline 15000 & Oceana & & & & & 43.79853 & -86.38219 & $16 \mathrm{~N}$ & $17 \mathrm{~W}$ & 7 & 622 & 2100 & $\mathrm{O}$ & 1 \\
\hline 15001 & Oceana & & & & & 43.80204 & -86.39691 & $16 \mathrm{~N}$ & $17 \mathrm{~W}$ & 7 & 631 & 2104 & $\mathrm{O}$ & 2 \\
\hline 15006 & Oceana & & & & & 43.80952 & -86.41679 & $16 \mathrm{~N}$ & $18 W$ & 1 & 593 & 2074 & $\mathrm{D}$ & 1 \\
\hline 15010 & Oceana & & & & & 43.80383 & -86.36467 & $16 \mathrm{~N}$ & $17 \mathrm{~W}$ & 8 & 654 & 2124 & $\mathrm{O}$ & 1 \\
\hline 15011 & Oceana & & & & & 43.81850 & -86.41482 & $16 \mathrm{~N}$ & $18 \mathrm{~W}$ & 1 & 607 & 2083 & $\mathrm{O}$ & 1 \\
\hline 15030 & Oceana & & & & & 43.80020 & -86.36967 & $16 \mathrm{~N}$ & $17 W$ & 8 & 643 & 2114 & $\mathrm{BD}$ & 1 \\
\hline 15050 & Oceana & & & & & 43.80209 & -86.37217 & $16 \mathrm{~N}$ & $17 \mathrm{~W}$ & 8 & 650 & 2120 & $\mathrm{O}$ & 1 \\
\hline 15059 & Oceana & & & & & 43.81619 & -86.36708 & $16 \mathrm{~N}$ & $17 \mathrm{~W}$ & 5 & 664 & 2144 & $\mathrm{D}$ & 1 \\
\hline 15061 & Oceana & & & & & 43.80570 & -86.37208 & $16 \mathrm{~N}$ & $17 \mathrm{~W}$ & 5 & 645 & \begin{tabular}{|l|}
2117 \\
\end{tabular} & $\mathrm{O}$ & 1 \\
\hline 15062 & Oceana & & & & & 43.80912 & -86.37246 & $16 \mathrm{~N}$ & $17 \mathrm{~W}$ & 5 & 649 & 2122 & $\mathrm{O}$ & 1 \\
\hline 15080 & Oceana & & & & & 43.80748 & -86.36958 & $16 \mathrm{~N}$ & $17 \mathrm{~W}$ & 5 & 649 & 2119 & $\mathrm{O}$ & 1 \\
\hline 15081 & Oceana & & & & & 43.80387 & -86.36967 & $16 \mathrm{~N}$ & $17 \mathrm{~W}$ & 8 & 650 & 2124 & $\mathrm{O}$ & 2 \\
\hline 15100 & Oceana & & & & & 43.80564 & -86.36708 & $16 \mathrm{~N}$ & $17 \mathrm{~W}$ & 5 & 645 & 2114 & $\mathrm{O}$ & 1 \\
\hline 15114 & Oceana & & & & & 43.79839 & -86.37720 & $16 \mathrm{~N}$ & $17 \mathrm{~W}$ & 8 & 623 & 2093 & $\mathrm{O}$ & 2 \\
\hline
\end{tabular}


M. Le, MS Thesis, 2004

\begin{tabular}{|c|c|c|c|c|c|c|c|c|c|c|c|c|c|c|}
\hline Permit & Name & RGRC & DNDE & DRRV & DRB & Latitude & Longitude & Twn & Rng & Sec & KB & TD & Type & Omit \\
\hline 15115 & Oceana & & & & & 43.80204 & -86.36717 & $16 \mathrm{~N}$ & $17 \mathrm{~W}$ & 8 & 654 & 2124 & 0 & 2 \\
\hline 15146 & Oceana & & & & & 43.79839 & -86.37217 & $16 \mathrm{~N}$ & $17 \mathrm{~W}$ & 8 & 647 & 2115 & $\mathrm{O}$ & 1 \\
\hline 15147 & Oceana & & & & & 43.80559 & -86.36211 & $16 \mathrm{~N}$ & $17 \mathrm{~W}$ & 5 & 650 & 2118 & $\mathrm{O}$ & 1 \\
\hline 15159 & Oceana & & & & & 43.80198 & -86.36212 & $16 \mathrm{~N}$ & $17 \mathrm{~W}$ & 8 & 654 & 2124 & $\mathrm{O}$ & 1 \\
\hline 15160 & Oceana & & & & & 43.79839 & -86.36717 & $16 \mathrm{~N}$ & $17 \mathrm{~W}$ & 8 & 641 & 2111 & $\mathrm{O}$ & 1 \\
\hline 15175 & Oceana & & & & & 43.81093 & -86.37457 & $16 \mathrm{~N}$ & $17 \mathrm{~W}$ & 5 & 660 & 2130 & $\mathrm{O}$ & 1 \\
\hline 15208 & Oceana & & & & & 43.80020 & -86.36467 & $16 \mathrm{~N}$ & $17 \mathrm{~W}$ & 8 & 643 & 2109 & $\mathrm{O}$ & 1 \\
\hline 15239 & Oceana & & & & & 43.80376 & -86.35961 & $16 \mathrm{~N}$ & $17 \mathrm{~W}$ & 8 & 643 & 2109 & $\mathrm{O}$ & 1 \\
\hline 15249 & Oceana & & & & & 43.81681 & -86.41180 & $16 \mathrm{~N}$ & $18 W$ & 1 & 586 & 2065 & $\mathrm{O}$ & 1 \\
\hline 15302 & Oceana & & & & & 43.80743 & -86.36458 & $16 \mathrm{~N}$ & $17 \mathrm{~W}$ & 5 & 654 & 2124 & $\mathrm{O}$ & 1 \\
\hline 15303 & Oceana & & & & & 43.81289 & -86.38204 & $16 \mathrm{~N}$ & $17 \mathrm{~W}$ & 6 & 670 & 2144 & $\mathrm{O}$ & 1 \\
\hline 15304 & Oceana & & & & & 43.80020 & -86.35962 & $16 \mathrm{~N}$ & $17 \mathrm{~W}$ & 8 & 644 & 2114 & $\mathrm{O}$ & 1 \\
\hline 15326 & Oceana & & & & & 43.79659 & -86.36967 & $16 \mathrm{~N}$ & $17 W$ & 8 & 616 & 2088 & $\mathrm{O}$ & 1 \\
\hline 15356 & Oceana & & & & & 43.80034 & -86.39444 & $16 \mathrm{~N}$ & $17 W$ & 7 & 635 & 2099 & $\mathrm{O}$ & 1 \\
\hline 15378 & Oceana & & & & & 43.79734 & -86.36219 & $16 \mathrm{~N}$ & $17 \mathrm{~W}$ & 8 & 638 & 0 & $\mathrm{D}$ & 1 \\
\hline 15398 & Oceana & & & & & 43.80552 & -86.35711 & $16 \mathrm{~N}$ & $17 \mathrm{~W}$ & 4 & 651 & 2114 & $\mathrm{O}$ & 1 \\
\hline 15413 & Oceana & & & & & 43.81109 & -86.37957 & $16 \mathrm{~N}$ & $17 W$ & 6 & 676 & 2139 & $\mathrm{O}$ & 2 \\
\hline 15414 & Oceana & & & & & 43.79659 & -86.36467 & $16 \mathrm{~N}$ & $17 \mathrm{~W}$ & 8 & 619 & 2087 & $\mathrm{O}$ & 1 \\
\hline 15446 & Oceana & & & & & 43.80912 & -86.36708 & $16 \mathrm{~N}$ & $17 \mathrm{~W}$ & 5 & 661 & 2140 & $\mathrm{O}$ & 1 \\
\hline 15491 & Oceana & & & & & 43.80737 & -86.35960 & $16 \mathrm{~N}$ & $17 \mathrm{~W}$ & 5 & 656 & 2120 & $\mathrm{O}$ & 2 \\
\hline 15525 & Oceana & & & & & 43.79659 & -86.37472 & $16 \mathrm{~N}$ & $17 \mathrm{~W}$ & 8 & 622 & 2095 & $\mathrm{O}$ & 1 \\
\hline 15544 & Oceana & & & & & 43.79806 & -86.35712 & $16 \mathrm{~N}$ & $17 \mathrm{~W}$ & 9 & 635 & 0 & $\mathrm{D}$ & 1 \\
\hline 15608 & Oceana & & & & & 43.80912 & -86.36210 & $16 \mathrm{~N}$ & $17 \mathrm{~W}$ & 5 & 653 & 2121 & $\mathrm{O}$ & 1 \\
\hline 15611 & Oceana & & & & & 43.80191 & -86.35711 & $16 \mathrm{~N}$ & $17 W$ & 9 & 652 & 2125 & $\mathrm{D}$ & 1 \\
\hline 15634 & Oceana & & & & & 43.81273 & -86.37208 & $16 \mathrm{~N}$ & $17 \mathrm{~W}$ & 5 & 659 & 2138 & $\mathrm{D}$ & 1 \\
\hline 15635 & Oceana & & & & & 43.80877 & -86.35710 & $16 \mathrm{~N}$ & $17 \mathrm{~W}$ & 4 & 659 & 2131 & $\mathrm{O}$ & 1 \\
\hline 16051 & Oceana & & & & & 43.81494 & -86.40930 & $16 \mathrm{~N}$ & $18 \mathrm{~W}$ & 1 & 591 & 2065 & $\mathrm{O}$ & 1 \\
\hline 16196 & Oceana & & & & & 43.81314 & -86.40679 & $16 \mathrm{~N}$ & $18 W$ & 1 & 598 & 2075 & $\mathrm{O}$ & 1 \\
\hline 16391 & Oceana & & & & & 43.81314 & -86.41180 & $16 \mathrm{~N}$ & $18 \mathrm{~W}$ & 1 & 590 & 2062 & $\mathrm{O}$ & 1 \\
\hline 17549 & Oceana & & & & & 43.80665 & -86.38086 & $16 \mathrm{~N}$ & $17 \mathrm{~W}$ & 6 & 651 & 0 & $\mathrm{D}$ & 2 \\
\hline 29168 & Oceana & & & & & 43.80332 & -86.37715 & $16 \mathrm{~N}$ & $17 \mathrm{~W}$ & 8 & 628 & 4254 & $\mathrm{G}$ & 1 \\
\hline 29588 & Oceana & & 2131 & 2254 & & 43.80246 & -86.38662 & $16 \mathrm{~N}$ & $17 \mathrm{~W}$ & 7 & 674 & 4265 & $\bar{G}$ & 3 \\
\hline
\end{tabular}


M. Le, MS Thesis, 2004

\begin{tabular}{|c|c|c|c|c|c|c|c|c|c|c|c|c|c|c|}
\hline Permit & Name & RGRC & DNDE & DRRV & DRB & Latitude & Longitude & Twn & Rng & Sec & $\mathrm{KB}$ & TD & Type & Omit \\
\hline 29607 & Oceana & & & & & 43.79795 & -86.37171 & $16 \mathrm{~N}$ & $17 \mathrm{~W}$ & 8 & 649 & 4230 & D & 1 \\
\hline 30045 & Oceana & & & & & 43.79766 & -86.38171 & $16 \mathrm{~N}$ & $17 \mathrm{~W}$ & 7 & 620 & 4237 & $\mathrm{D}$ & 1 \\
\hline 30046 & Oceana & & & & & 43.80943 & -86.36660 & $16 \mathrm{~N}$ & $17 \mathrm{~W}$ & 5 & 665 & 4300 & $\mathrm{G}$ & 1 \\
\hline 31504 & Oceana & & & & & 43.81030 & -86.37065 & $16 \mathrm{~N}$ & $17 \mathrm{~W}$ & 5 & 649 & 4285 & $\mathrm{D}$ & 5 \\
\hline 32517 & Oceana & 2635 & 2640 & 2792 & & 43.78080 & -86.13099 & $16 \mathrm{~N}$ & $15 W$ & 17 & 940 & 6561 & $\mathrm{D}$ & 2 \\
\hline 33134 & Oceana & & 2099 & 2211 & 2274 & 43.53448 & -86.44577 & $13 N$ & $18 W$ & 10 & 752 & 7240 & $\mathrm{D}$ & 2 \\
\hline 33134 & Oceana & & & & & 43.53448 & -86.44577 & $13 \mathrm{~N}$ & $18 W$ & 10 & 752 & 7240 & $\mathrm{D}$ & 2 \\
\hline 33154 & Oceana & & 2210 & 2334 & 2389 & 43.60269 & -86.44004 & $14 N$ & $18 W$ & 15 & 713 & 5065 & $\mathrm{O}$ & 1 \\
\hline 33154 & Oceana & & & & & 43.60269 & -86.44004 & $14 \mathrm{~N}$ & $18 \mathrm{~W}$ & 15 & 713 & 5065 & $\mathrm{O}$ & 2 \\
\hline 33493 & Oceana & & & & & 43.81007 & -86.38018 & $16 \mathrm{~N}$ & $17 \mathrm{~W}$ & 6 & 667 & 4290 & BD & 2 \\
\hline 34479 & Oceana & & & & & 43.80306 & -86.38230 & $16 \mathrm{~N}$ & $17 \mathrm{~W}$ & 7 & 651 & 4250 & $\mathrm{D}$ & 2 \\
\hline 34490 & Oceana & & & & & 43.80733 & -86.37513 & $16 \mathrm{~N}$ & $17 \mathrm{~W}$ & 5 & 652 & 4272 & $\mathrm{D}$ & 2 \\
\hline 40121 & Oceana & 2687 & 2692 & 2814 & & 43.67282 & -86.23446 & $15 \mathrm{~N}$ & $16 W$ & 21 & 962 & 6518 & $\mathrm{G}$ & 1 \\
\hline 40121 & Oceana & & & & & 43.67282 & -86.23446 & $15 \mathrm{~N}$ & $16 W$ & 21 & 962 & 6518 & $\mathrm{G}$ & \\
\hline 25099 & Ogemaw & & & & & 44.43633 & -84.19110 & $24 \mathrm{~N}$ & $2 \mathrm{E}$ & 28 & 1476 & 12996 & $D$ & 1 \\
\hline 39432 & Ogemaw & 2766 & 2841 & 3104 & & 44.30357 & -83.97046 & $22 \mathrm{~N}$ & $4 \mathrm{E}$ & 17 & 902 & 11538 & $\mathrm{D}$ & 1 \\
\hline 39749 & Ogemaw & 2539 & 2619 & 2888 & & 44.26493 & -84.15769 & $22 \mathrm{~N}$ & $2 E$ & 26 & 915 & 12000 & $\mathrm{GC}$ & 1 \\
\hline 40263 & Ogemaw & 2760 & 2840 & 3098 & 3273 & 44.33696 & -84.04083 & $23 \mathrm{~N}$ & $3 E$ & 35 & 897 & 11600 & $\mathrm{D}$ & 1 \\
\hline 40372 & Ogemaw & 2963 & 3063 & 3240 & & 44.44652 & -84.19308 & $24 \mathrm{~N}$ & $2 \mathrm{E}$ & 28 & 1483 & 11000 & $G$ & 1 \\
\hline 40546 & Ogemaw & 2782 & 2862 & 3044 & 3249 & 44.29657 & -84.23553 & $22 \mathrm{~N}$ & $2 E$ & 18 & 1072 & 11720 & $\mathrm{GC}$ & 2 \\
\hline 34536 & Osceola & 3709 & 3739 & 3991 & 4176 & 43.92299 & -85.25983 & $18 \mathrm{~N}$ & $8 W$ & 27 & 1055 & 4918 & $\mathrm{O}$ & 1 \\
\hline 34536 & Osceola & & & & & 43.92299 & -85.25983 & $18 \mathrm{~N}$ & $8 W$ & 27 & 1055 & 4918 & $\mathrm{O}$ & 2 \\
\hline 34558 & Osceola & 3881 & 3906 & 4108 & & 43.82640 & -85.30818 & $17 N$ & $8 W$ & 31 & 1117 & 10858 & $\mathrm{D}$ & 2 \\
\hline 35482 & Osceola & 4011 & 4061 & 4257 & & 43.99551 & -85.18905 & $19 \mathrm{~N}$ & $7 \mathrm{~W}$ & 31 & 1116 & 11300 & $\mathrm{D}$ & 1 \\
\hline 35800 & Osceola & & & & & 43.82741 & -85.32228 & $17 \mathrm{~N}$ & $8 W$ & 31 & 1154 & 9769 & $\mathrm{G}$ & \\
\hline 35832 & Osceola & 3891 & 3926 & 4120 & 4320 & 43.86690 & -85.09448 & $17 \mathrm{~N}$ & $7 \mathrm{~W}$ & 13 & 1074 & 10505 & $\mathrm{O}$ & 1 \\
\hline 35977 & Osceola & & & & & 43.84209 & -85.31157 & $17 N$ & $8 W$ & 30 & 1116 & 8371 & $\mathrm{D}$ & \\
\hline 36068 & Osceola & & & & & 43.82636 & -85.32711 & $17 N$ & $9 W$ & 36 & 1125 & 8200 & $G$ & \\
\hline 36110 & Osceola & & & & & 43.82022 & -85.33099 & $17 \mathrm{~N}$ & $9 W$ & 36 & 1201 & 8366 & $G$ & \\
\hline 36186 & Osceola & & & & & 43.82727 & -85.35079 & $17 \mathrm{~N}$ & $9 W$ & 35 & 1215 & 8309 & $\mathrm{G}$ & \\
\hline 36426 & Osceola & & & & & 43.83433 & -85.28275 & $17 \mathrm{~N}$ & $8 W$ & 28 & 1123 & 8440 & $\mathrm{D}$ & \\
\hline 36426 & Osceola & & & & & 43.83433 & -85.28275 & $17 \mathrm{~N}$ & $8 W$ & 28 & 1123 & 8440 & $D$ & \\
\hline
\end{tabular}


M. Le, MS Thesis, 2004

\begin{tabular}{|c|c|c|c|c|c|c|c|c|c|c|c|c|c|c|}
\hline Permit & Name & RGRC & DNDE & DRRV & DRB & Latitude & Longitude & Twn & Rng & Sec & $\mathrm{KB}$ & TD & Type & Omit \\
\hline 36506 & Osceola & 3757 & 3782 & 4003 & & 43.86564 & -85.32818 & $17 \mathrm{~N}$ & $9 W$ & 13 & 1044 & 8310 & BD & 1 \\
\hline 36506 & Osceola & & & & & 43.86564 & -85.32818 & $17 \mathrm{~N}$ & $9 W$ & 13 & 1044 & 8310 & $\mathrm{BD}$ & \\
\hline 36600 & Osceola & & & & & 43.84165 & -85.36087 & $17 \mathrm{~N}$ & $9 \mathrm{~W}$ & 26 & 1137 & 8085 & $\mathrm{D}$ & \\
\hline 36600 & Osceola & & & & & 43.84165 & -85.36087 & $17 \mathrm{~N}$ & $9 W$ & 26 & 1137 & 8085 & $\mathrm{D}$ & \\
\hline 36648 & Osceola & 3551 & 3571 & 3779 & & 43.82801 & -85.41790 & $17 \mathrm{~N}$ & $9 W$ & 32 & 1002 & 7796 & $\mathrm{D}$ & 1 \\
\hline 36648 & Osceola & & & & & 43.82801 & -85.41790 & $17 \mathrm{~N}$ & $9 \mathrm{~W}$ & 32 & 1002 & 7796 & $\mathrm{D}$ & \\
\hline 36925 & Osceola & & & & & 43.82022 & -85.34092 & $17 \mathrm{~N}$ & $9 W$ & 36 & 1183 & 8200 & $\mathrm{G}$ & \\
\hline 37193 & Osceola & & & & & 44.15447 & -85.40430 & $20 \mathrm{~N}$ & $9 \mathrm{~W}$ & 4 & 1347 & 5300 & $\mathrm{D}$ & \\
\hline 37274 & Osceola & & & & & 43.87461 & -85.20378 & $17 \mathrm{~N}$ & $7 \mathrm{~W}$ & 7 & 1125 & 4850 & $\mathrm{G}$ & \\
\hline 37300 & Osceola & 3920 & 3945 & 4152 & & 43.86709 & -85.27497 & $17 \mathrm{~N}$ & $8 W$ & 16 & 1148 & 5180 & D & 1 \\
\hline 37317 & Osceola & & & & & 43.83348 & -85.34621 & $17 \mathrm{~N}$ & $9 \mathrm{~W}$ & 26 & 1140 & 8095 & $\mathrm{G}$ & \\
\hline 37655 & Osceola & & & & & 43.86523 & -85.26239 & $17 \mathrm{~N}$ & $8 W$ & 15 & 1157 & 5170 & $\mathrm{D}$ & \\
\hline 38005 & Osceola & & & & & 43.88110 & -85.20380 & $17 \mathrm{~N}$ & $7 \mathrm{~W}$ & 7 & 1098 & 5070 & $\mathrm{O}$ & \\
\hline 38076 & Osceola & & & & & 43.87572 & -85.19338 & $17 \mathrm{~N}$ & $7 \mathrm{~W}$ & 7 & 1085 & 5050 & $\mathrm{D}$ & \\
\hline 38201 & Osceola & 3918 & 3948 & 4164 & & 44.16126 & -85.39724 & $20 N$ & $9 W$ & 4 & 1353 & 5310 & $\mathrm{O}$ & 1 \\
\hline 38463 & Osceola & & & & & 43.84391 & -85.31368 & $17 \mathrm{~N}$ & $8 W$ & 19 & 1120 & 8385 & $\mathrm{D}$ & \\
\hline 38748 & Osceola & & & & & 43.82376 & -85.34584 & $17 \mathrm{~N}$ & $9 W$ & 35 & 1215 & 8206 & $\mathrm{G}$ & \\
\hline 39433 & Osceola & 3892 & 3917 & 4121 & 4297 & 43.91237 & -85.38690 & $18 \mathrm{~N}$ & $9 W$ & 33 & 1254 & 10525 & $\mathrm{D}$ & 2 \\
\hline 39854 & Osceola & 3818 & 3838 & 4064 & 4202 & 44.10851 & -85.55086 & $20 N$ & $10 W$ & 19 & 1213 & $12808^{*}$ & $\mathrm{G}$ & 1 \\
\hline 40137 & Osceola & 3721 & 3741 & 3955 & 4120 & 43.98567 & -85.44885 & $18 \mathrm{~N}$ & $10 \mathrm{~W}$ & 1 & 1250 & 10556 & $\mathrm{G}$ & 1 \\
\hline 40333 & Osceola & 3953 & 3983 & 4205 & & 43.87503 & -85.20880 & $17 \mathrm{~N}$ & $8 W$ & 12 & 1109 & 5120 & $\mathrm{G}$ & 1 \\
\hline 40556 & Osceola & 3700 & 3720 & 3940 & 4111 & 44.01405 & -85.48881 & $19 \mathrm{~N}$ & $10 \mathrm{~W}$ & 27 & 1228 & 10550 & $\mathrm{G}$ & 2 \\
\hline 40638 & Osceola & & & & & 43.86920 & -85.20377 & $17 \mathrm{~N}$ & $7 W$ & 18 & 1100 & 5070 & $\mathrm{G}$ & \\
\hline 40810 & Osceola & 3998 & 4043 & 4247 & 4460 & 44.09971 & -85.17121 & $20 N$ & $7 \mathrm{~W}$ & 29 & 1167 & 11549 & $\mathrm{D}$ & 1 \\
\hline 40810 & Osceola & & & & & 44.09971 & -85.17121 & $20 N$ & $7 \mathrm{~W}$ & 29 & 1167 & 11549 & $D$ & \\
\hline 40837 & Osceola & & & & & 43.99795 & -85.42006 & $19 \mathrm{~N}$ & $9 W$ & 32 & 1300 & 10559 & $G$ & \\
\hline 40924 & Osceola & & & & & 43.98470 & -85.44046 & $18 \mathrm{~N}$ & $9 W$ & 6 & 1277 & 10410 & $\mathrm{D}$ & \\
\hline 40924 & Osceola & & & & & 43.98470 & -85.44046 & $18 \mathrm{~N}$ & $9 W$ & 6 & 1277 & 10410 & $D$ & \\
\hline 40945 & Osceola & & & & & 43.96275 & -85.44190 & $18 \mathrm{~N}$ & $9 W$ & 7 & 1199 & 10375 & $\mathrm{D}$ & \\
\hline 41326 & Osceola & & & & & 43.88063 & -85.20879 & $17 \mathrm{~N}$ & $8 W$ & 12 & 1099 & 5130 & D & \\
\hline 41343 & Osceola & & & & & 43.86949 & -85.20865 & $17 \mathrm{~N}$ & $8 W$ & 13 & 1103 & 4810 & $\mathrm{D}$ & \\
\hline 41354 & Osceola & & & & & 44.11050 & -85.40956 & $20 \mathrm{~N}$ & $9 W$ & 20 & 1305 & 11500 & $\mathrm{G}$ & \\
\hline
\end{tabular}

$$
\text { A-24 }
$$


M. Le, MS Thesis, 2004

\begin{tabular}{|c|c|c|c|c|c|c|c|c|c|c|c|c|c|c|}
\hline Permit & Name & RGRC & DNDE & DRRV & DRB & Latitude & Longitude & Twn & Rng & Sec & $\mathrm{KB}$ & TD & Type & Omit \\
\hline 41540 & Osceola & 3728 & 3748 & 3962 & & 43.87598 & -85.43952 & $17 N$ & $9 W$ & 7 & 1157 & 10100 & D & 1 \\
\hline 41612 & Osceola & 4055 & 4080 & 4298 & & 44.04734 & -85.36573 & $19 N$ & $9 W$ & 10 & 1329 & 11120 & $\mathrm{G}$ & 1 \\
\hline 41777 & Osceola & 4115 & 4160 & 4362 & & 44.06839 & -85.22290 & $19 \mathrm{~N}$ & $8 W$ & 1 & 1236 & 11540 & $\mathrm{D}$ & 1 \\
\hline 41795 & Osceola & 3764 & 3814 & 4021 & 4232 & 44.08356 & -85.09151 & $20 \mathrm{~N}$ & $7 \mathrm{~W}$ & 36 & 1148 & 11744 & $\mathrm{G}$ & 3 \\
\hline 41795 & Osceola & & & & & 44.08356 & -85.09151 & $20 \mathrm{~N}$ & $7 \mathrm{~W}$ & 36 & 1148 & 11744 & $\mathrm{G}$ & \\
\hline 42313 & Osceola & 4128 & 4163 & 4375 & & 44.12524 & -85.29071 & $20 \mathrm{~N}$ & $8 W$ & 17 & 1439 & 11568 & $\mathrm{G}$ & 1 \\
\hline 42421 & Osceola & & & & & 44.01218 & -85.36861 & $19 \mathrm{~N}$ & $9 W$ & 27 & 1428 & 11105 & $\mathrm{D}$ & \\
\hline 42421 & Osceola & & & & & 44.01218 & -85.36861 & $19 \mathrm{~N}$ & $9 W$ & 27 & 1428 & 11105 & $\mathrm{D}$ & \\
\hline 42596 & Osceola & 3923 & 3953 & 4151 & 4321 & 43.82570 & -85.17309 & $17 N$ & $7 \mathrm{~W}$ & 32 & 1137 & 10894 & $\mathrm{D}$ & 6 \\
\hline 42635 & Osceola & & & & & 43.96820 & -85.48904 & $18 \mathrm{~N}$ & 10W & 10 & 1183 & 10175 & $\mathrm{D}$ & \\
\hline 42945 & Osceola & & & & & 44.00462 & -85.25098 & $19 \mathrm{~N}$ & $8 W$ & 27 & 1283 & 11500 & $\mathrm{D}$ & \\
\hline 42956 & Osceola & & & & & 43.89596 & -85.39608 & $17 \mathrm{~N}$ & $9 W$ & 4 & 1130 & 10290 & $D$ & \\
\hline 43365 & Osceola & & & & & 44.11574 & -85.32357 & $20 N$ & $8 W$ & 19 & 1487 & 11541 & $\mathrm{D}$ & \\
\hline 44238 & Osceola & & & & & 44.04372 & -85.43659 & $19 \mathrm{~N}$ & $9 W$ & 18 & 1287 & 10840 & $\mathrm{G}$ & \\
\hline 34070 & Oscoda & 2982 & 3082 & 3239 & 3520 & 44.55701 & -84.16123 & $25 \mathrm{~N}$ & $2 E$ & 14 & 1179 & 11691 & $\mathrm{G}$ & 1 \\
\hline 34494 & Oscoda & 3077 & 3177 & 3337 & & 44.57129 & -84.18174 & $25 \mathrm{~N}$ & $2 E$ & 10 & 1176 & 11200 & $\mathrm{D}$ & 1 \\
\hline 37145 & Oscoda & 2830 & 2930 & 3117 & & 44.67870 & -84.30963 & $26 \mathrm{~N}$ & $1 \mathrm{E}$ & 3 & 1062 & 9671 & $\mathrm{D}$ & 1 \\
\hline 40651 & Oscoda & 2551 & 2651 & 2807 & & 44.72759 & -84.09876 & $27 \mathrm{~N}$ & $3 \mathrm{E}$ & 17 & 1129 & 10276 & $\mathrm{D}$ & 1 \\
\hline 40891 & Oscoda & & & & & 44.54783 & -84.15510 & $25 \mathrm{~N}$ & $2 \mathrm{E}$ & 23 & 1281 & 11300 & $\mathrm{G}$ & \\
\hline 41392 & Oscoda & 2995 & 3095 & 3271 & & 44.55379 & -84.19753 & $25 \mathrm{~N}$ & $2 E$ & 16 & 1221 & 11027 & $\mathrm{G}$ & 2 \\
\hline 41462 & Oscoda & & & & & 44.55391 & -84.15460 & $25 \mathrm{~N}$ & $2 \mathrm{E}$ & 14 & 1182 & 10400 & $\mathrm{G}$ & \\
\hline 25873 & Otsego & 2400 & 2475 & 2615 & & 44.94373 & -84.76486 & $29 \mathrm{~N}$ & $4 W$ & 2 & 1413 & 8372 & $D$ & 1 \\
\hline 28375 & Otsego & 2326 & 2401 & 2566 & & 44.99153 & -84.59010 & $30 N$ & $2 W$ & 18 & 1334 & 6330 & $\mathrm{O}$ & 1 \\
\hline 28463 & Otsego & 2347 & 2422 & 2582 & & 44.99224 & -84.57491 & $30 \mathrm{~N}$ & $2 W$ & 17 & 1335 & 6327 & $\mathrm{D}$ & 1 \\
\hline 28516 & Otsego & & & & & 44.99881 & -84.58627 & $30 \mathrm{~N}$ & $2 W$ & 17 & 1343 & 6270 & $\mathrm{O}$ & 1 \\
\hline 28593 & Otsego & & & & & 44.98891 & -84.59520 & $30 N$ & $2 W$ & 18 & 1315 & 6030 & $\mathrm{O}$ & 1 \\
\hline 28630 & Otsego & & & & & 44.98819 & -84.60746 & $30 \mathrm{~N}$ & $3 W$ & 13 & 1318 & 6289 & $\mathrm{D}$ & 1 \\
\hline 28709 & Otsego & & & & & 44.99971 & -84.58933 & $30 \mathrm{~N}$ & $2 W$ & 18 & 1345 & 6030 & $\mathrm{O}$ & 1 \\
\hline 28738 & Otsego & & & & & 44.98969 & -84.58569 & $30 \mathrm{~N}$ & $2 W$ & 17 & 1319 & 6060 & WI & 1 \\
\hline 28797 & Otsego & & & & & 44.99522 & -84.59393 & $30 \mathrm{~N}$ & $2 W$ & 18 & 1330 & 6025 & $\mathrm{O}$ & 1 \\
\hline 28815 & Otsego & & & & & 44.99152 & -84.58617 & $30 \mathrm{~N}$ & $2 W$ & 17 & 1319 & 6050 & $\mathrm{O}$ & 1 \\
\hline 28840 & Otsego & & & & & 44.98627 & -84.59901 & $30 \mathrm{~N}$ & $2 W$ & 19 & 1316 & 6050 & $\mathrm{O}$ & 1 \\
\hline
\end{tabular}


M. Le, MS Thesis, 2004

\begin{tabular}{|c|c|c|c|c|c|c|c|c|c|c|c|c|c|c|}
\hline Permit & Name & RGRC & DNDE & DRRV & DRB & Latitude & Longitude & Twn & Rng & Sec & $\mathrm{KB}$ & TD & Type & Omit \\
\hline 28841 & Otsego & & & & & 45.01017 & -84.57164 & $30 N$ & $2 W$ & 8 & 1333 & 6090 & $D$ & 1 \\
\hline 28924 & Otsego & & & & & 44.99693 & -84.58369 & $30 \mathrm{~N}$ & $2 W$ & 17 & 1344 & 6044 & $\mathrm{O}$ & 1 \\
\hline 28925 & Otsego & & & & & 44.98808 & -84.59902 & $30 \mathrm{~N}$ & $2 W$ & 18 & 1320 & 6025 & $\mathrm{O}$ & 1 \\
\hline 29679 & Otsego & 2308 & 2383 & 2541 & & 44.99077 & -84.61123 & $30 \mathrm{~N}$ & $3 W$ & 13 & 1315 & 6240 & $\mathrm{D}$ & 1 \\
\hline 29853 & Otsego & 2294 & 2369 & 2534 & & 45.00235 & -84.58133 & $30 \mathrm{~N}$ & $2 W$ & 8 & 1338 & 6161 & $\mathrm{O}$ & 1 \\
\hline 30084 & Otsego & & & & & 45.01531 & -84.47288 & $30 \mathrm{~N}$ & $1 \mathrm{~W}$ & 6 & 1334 & 6071 & $\mathrm{D}$ & 1 \\
\hline 30418 & Otsego & & & & & 44.99259 & -84.59902 & $30 \mathrm{~N}$ & $2 W$ & 18 & 1318 & 6000 & $\mathrm{O}$ & 1 \\
\hline 30618 & Otsego & & & & & 45.00275 & -84.58935 & $30 \mathrm{~N}$ & $2 W$ & 7 & 1345 & 6080 & $\mathrm{D}$ & 1 \\
\hline 30680 & Otsego & & & & & 45.00275 & -84.58935 & $30 \mathrm{~N}$ & $2 W$ & 7 & 1345 & 6105 & $\mathrm{WI}$ & 1 \\
\hline 30847 & Otsego & & & & & 44.95327 & -84.38941 & $30 \mathrm{~N}$ & $1 \mathrm{~W}$ & 36 & 1323 & 6400 & $\mathrm{D}$ & 1 \\
\hline 31325 & Otsego & & & & & 44.98590 & -84.60426 & $30 \mathrm{~N}$ & $2 W$ & 19 & 1317 & 6235 & $\mathrm{D}$ & 5 \\
\hline 31415 & Otsego & & & & & 44.98600 & -84.60448 & $30 \mathrm{~N}$ & $2 W$ & 19 & 1317 & 6150 & $\mathrm{BD}$ & 2 \\
\hline 32509 & Otsego & & & & & 44.99973 & -84.58038 & $30 N$ & $2 W$ & 17 & 1331 & 6060 & WI & 2 \\
\hline 32510 & Otsego & & & & & 44.99540 & -84.58836 & $30 \mathrm{~N}$ & $2 W$ & 18 & 1332 & 5980 & $\mathrm{WI}$ & 2 \\
\hline 32531 & Otsego & & & & & 44.99031 & -84.59377 & $30 \mathrm{~N}$ & $2 W$ & 18 & 1322 & 6025 & WI & 2 \\
\hline 35113 & Otsego & 2257 & 2332 & 2502 & & 44.99035 & -84.44035 & $30 \mathrm{~N}$ & $1 \mathrm{~W}$ & 16 & 1374 & 8710 & $\mathrm{GC}$ & 2 \\
\hline 35922 & Otsego & & & & & 44.97396 & -84.44005 & $30 \mathrm{~N}$ & $1 \mathrm{~W}$ & 21 & 1367 & 8183 & D & \\
\hline 36616 & Otsego & & & & & 44.99371 & -84.58495 & $30 \mathrm{~N}$ & $2 W$ & 17 & 1319 & 6070 & $D$ & \\
\hline 36623 & Otsego & & & & & 44.99931 & -84.58040 & $30 N$ & $2 W$ & 17 & 1331 & 5915 & WI & \\
\hline 36636 & Otsego & 2321 & 2396 & 2559 & & 45.00600 & -84.59569 & $30 \mathrm{~N}$ & $2 W$ & 18 & 1335 & 6039 & $D$ & 1 \\
\hline 36636 & Otsego & & & & & 45.00600 & -84.59569 & $30 N$ & $2 W$ & 18 & 1335 & 6039 & $D$ & \\
\hline 36636 & Otsego & & & & & 45.00600 & -84.59569 & $30 \mathrm{~N}$ & $2 W$ & 18 & 1335 & 6039 & $D$ & \\
\hline 37136 & Otsego & & & & & 44.99552 & -84.58899 & $30 \mathrm{~N}$ & $2 W$ & 18 & 1334 & 6029 & $\mathrm{WI}$ & \\
\hline 37366 & Otsego & & & & & 45.00380 & -84.57659 & $30 \mathrm{~N}$ & $2 W$ & 8 & 1335 & 6305 & $\mathrm{D}$ & \\
\hline 41541 & Otsego & & & & & 45.00459 & -84.49168 & $30 \mathrm{~N}$ & $2 W$ & 12 & 1338 & 1705 & $\mathrm{G}$ & \\
\hline 34268 & Ottawa & & 2030 & 2152 & 2227 & 42.93424 & -86.02595 & $6 \mathrm{~N}$ & $15 \mathrm{~W}$ & 1 & 638 & $5060^{*}$ & $\mathrm{D}$ & 2 \\
\hline 34885 & Ottawa & 2570 & 2571 & 2692 & 2767 & 43.11667 & -85.83628 & $8 \mathrm{~N}$ & $13 \mathrm{~W}$ & 3 & 891 & 7245 & $\mathrm{D}$ & 1 \\
\hline 39591 & Ottawa & & 2183 & 2307 & 2393 & 42.94096 & -85.87766 & $6 \mathrm{~N}$ & $13 \mathrm{~W}$ & 5 & 731 & 4930 & $\mathrm{D}$ & 1 \\
\hline $99969 \quad 139$ & Ottawa & & 1745 & 1842 & 1911 & 42.78379 & -86.13119 & $05 \mathrm{~N}$ & 15W & 30 & 617 & 5913 & $\mathrm{BD}$ & \\
\hline 22638 & Presque Isle & 371 & 461 & 595 & & 45.32012 & -83.85440 & $34 \mathrm{~N}$ & $5 \mathrm{E}$ & 20 & 844 & 5137 & $\mathrm{D}$ & 2 \\
\hline 27199 & Presque Isle & 185 & 265 & 420 & & 45.38253 & -84.21398 & $35 \mathrm{~N}$ & $2 E$ & 29 & 809 & 5940 & $\mathrm{BD}$ & 1 \\
\hline 29372 & Presque Isle & & & & & 45.25227 & -83.76800 & $33 N$ & $5 E$ & 13 & 776 & 6738 & $\mathrm{DH}$ & 1 \\
\hline
\end{tabular}

$$
\text { A-26 }
$$


M. Le, MS Thesis, 2004

\begin{tabular}{|c|c|c|c|c|c|c|c|c|c|c|c|c|c|c|}
\hline Permit & Name & RGRC & DNDE & DRRV & DRB & Latitude & Longitude & Twn & Rng & Sec & $\mathrm{KB}$ & TD & Type & Omit \\
\hline 34957 & Presque Isle & & & & & 45.22206 & -84.24019 & $33 N$ & $2 E$ & 30 & 857 & 6193 & $\mathrm{DH}$ & \\
\hline 35085 & Presque Isle & 575 & 660 & 823 & & 45.24635 & -84.04134 & $33 \mathrm{~N}$ & $3 \mathrm{E}$ & 14 & 903 & 6667 & $\mathrm{D}$ & 1 \\
\hline 34537 & Roscommon & 3686 & 3761 & 3993 & 4235 & 44.29655 & -84.79610 & $22 \mathrm{~N}$ & $4 \mathrm{~W}$ & 16 & 1141 & 12288 & $\mathrm{D}$ & 1 \\
\hline 37134 & Roscommon & 2853 & 2943 & 3127 & & 44.47452 & -84.39557 & $24 \mathrm{~N}$ & $1 \mathrm{~W}$ & 14 & 1202 & 11401 & $\mathrm{D}$ & 1 \\
\hline 37409 & Roscommon & 3892 & 3967 & 4181 & 4418 & 44.21285 & -84.46533 & $21 \mathrm{~N}$ & $1 \mathrm{~W}$ & 17 & 1240 & 11995 & $\mathrm{D}$ & 1 \\
\hline 39941 & Roscommon & & & & & 44.18321 & -84.70416 & $21 \mathrm{~N}$ & $3 W$ & 29 & 1171 & 5370 & $\mathrm{O}$ & \\
\hline 41032 & Roscommon & 3293 & 3368 & 3582 & 3807 & 44.35943 & -84.82008 & $23 N$ & $4 W$ & 29 & 1171 & 11930 & $\mathrm{D}$ & 1 \\
\hline 35444 & Saginaw & 2789 & 2814 & 3085 & 3123 & 43.29148 & -83.97328 & $10 \mathrm{~N}$ & $4 \mathrm{E}$ & 10 & 608 & 3779 & $\mathrm{D}$ & 2 \\
\hline 35852 & Saginaw & 2704 & 2729 & 3003 & 3035 & 43.18686 & -84.05434 & $9 N$ & $3 E$ & 13 & 653 & 3537 & $\mathrm{D}$ & 1 \\
\hline 36137 & Saginaw & 2895 & 2935 & 3240 & & 43.41144 & -83.83603 & $12 \mathrm{~N}$ & $5 \mathrm{E}$ & 25 & 618 & 3309 & $\mathrm{D}$ & 1 \\
\hline 25357 & Sanilac & & 1429 & 1585 & 1587 & 43.21796 & -82.70857 & $9 \mathrm{~N}$ & $15 \mathrm{E}$ & 16 & 769 & 6784 & $\mathrm{D}$ & 3 \\
\hline 30974 & Sanilac & 1777 & 1797 & 2023 & 2025 & 43.45595 & -82.72035 & $12 \mathrm{~N}$ & $15 \mathrm{E}$ & 20 & 785 & 8975 & $\mathrm{D}$ & 3 \\
\hline 33999 & Sanilac & 1982 & 1987 & 2206 & 2169 & 43.28814 & -82.75597 & $10 \mathrm{~N}$ & $15 \mathrm{E}$ & 19 & 765 & 8511 & $\mathrm{D}$ & 1 \\
\hline 35779 & Sanilac & 1490 & 1500 & 1621 & 1679 & 43.35292 & -82.72822 & $11 \mathrm{~N}$ & $15 \mathrm{E}$ & 30 & 775 & 7824 & $\mathrm{D}$ & 1 \\
\hline 27907 & Shiawassee & 2308 & 2318 & 2506 & 2530 & 42.85657 & -84.25114 & $5 \mathrm{~N}$ & $2 E$ & 5 & 843 & 7056 & $\mathrm{D}$ & 1 \\
\hline 30727 & Shiawassee & 2681 & 2696 & 2918 & 2936 & 42.95372 & -84.35925 & $6 \mathrm{~N}$ & $1 \mathrm{E}$ & 5 & 783 & 7672 & $\mathrm{D}$ & 1 \\
\hline 22814 & St. Clair & & & & & 42.78161 & -82.53681 & $4 \mathrm{~N}$ & $16 \mathrm{E}$ & 15 & 607 & 2610 & $\mathrm{D}$ & 1 \\
\hline 23146 & St. Clair & & & & & 42.77801 & -82.53680 & $4 \mathrm{~N}$ & $16 \mathrm{E}$ & 15 & 618 & 2592 & $\mathrm{D}$ & 1 \\
\hline 23205 & St. Clair & & & & & 42.77871 & -82.54118 & $4 \mathrm{~N}$ & $16 \mathrm{E}$ & 15 & 622 & 0 & $\mathrm{D}$ & 2 \\
\hline 23231 & St. Clair & & & & & 42.77114 & -82.53113 & $4 \mathrm{~N}$ & $16 \mathrm{E}$ & 23 & 606 & 0 & $\mathrm{D}$ & 2 \\
\hline 23234 & St. Clair & & & & & 42.78601 & -82.53667 & $4 \mathrm{~N}$ & $16 \mathrm{E}$ & 15 & 616 & 0 & $D$ & 2 \\
\hline 23249 & St. Clair & & & & & 42.78213 & -82.53134 & $4 \mathrm{~N}$ & $16 \mathrm{E}$ & 14 & 618 & 0 & $\mathrm{D}$ & 2 \\
\hline 23303 & St. Clair & & & & & 42.77473 & -82.53702 & $4 \mathrm{~N}$ & $16 \mathrm{E}$ & 15 & 618 & 2522 & $\mathrm{D}$ & 1 \\
\hline 23327 & St. Clair & & & & & 42.78575 & -82.53262 & $4 \mathrm{~N}$ & $16 \mathrm{E}$ & 14 & 620 & 2520 & $\mathrm{D}$ & 1 \\
\hline 23367 & St. Clair & & & & & 42.77163 & -82.51611 & $4 \mathrm{~N}$ & $16 \mathrm{E}$ & 23 & 592 & 0 & $D$ & 2 \\
\hline 23384 & St. Clair & & & & & 42.77819 & -82.53227 & $4 \mathrm{~N}$ & $16 \mathrm{E}$ & 14 & 613 & 2545 & $\mathrm{D}$ & 1 \\
\hline 23409 & St. Clair & & & & & 42.78221 & -82.52730 & $4 \mathrm{~N}$ & $16 \mathrm{E}$ & 14 & 604 & 2510 & $\mathrm{D}$ & 1 \\
\hline 23525 & St. Clair & & & & & 42.79347 & -82.52819 & $4 \mathrm{~N}$ & $16 \mathrm{E}$ & 11 & 615 & 2525 & $D$ & 2 \\
\hline 23541 & St. Clair & & & & & 42.78543 & -82.54225 & $4 N$ & $16 \mathrm{E}$ & 15 & 619 & 2532 & $\mathrm{D}$ & 1 \\
\hline 23542 & St. Clair & & & & & 42.78919 & -82.53770 & $4 \mathrm{~N}$ & $16 \mathrm{E}$ & 10 & 616 & 2526 & $\mathrm{D}$ & 2 \\
\hline 23543 & St. Clair & & & & & 42.78952 & -82.52801 & $4 \mathrm{~N}$ & $16 \mathrm{E}$ & 11 & 614 & 2516 & $\mathrm{D}$ & 2 \\
\hline 23556 & St. Clair & & & & & 42.78936 & -82.53279 & $4 N$ & $16 \mathrm{E}$ & 11 & 619 & 2536 & $\mathrm{D}$ & 2 \\
\hline
\end{tabular}


M. Le, MS Thesis, 2004

\begin{tabular}{|c|c|c|c|c|c|c|c|c|c|c|c|c|c|c|}
\hline Permit & Name & RGRC & DNDE & DRRV & DRB & Latitude & Longitude & Twn & Rng & Sec & KB & TD & Type & Omit \\
\hline 23671 & St. Clair & & & & & 42.79347 & -82.52309 & $4 N$ & $16 \mathrm{E}$ & 11 & 606 & 2507 & D & 2 \\
\hline 23672 & St. Clair & & & & & 42.79714 & -82.52819 & $4 \mathrm{~N}$ & $16 \mathrm{E}$ & 11 & 614 & 2512 & $\mathrm{D}$ & 2 \\
\hline 23707 & St. Clair & & & & & 42.78968 & -82.52309 & $4 \mathrm{~N}$ & $16 \mathrm{E}$ & 11 & 605 & 2508 & $\mathrm{G}$ & 2 \\
\hline 23729 & St. Clair & & & & & 42.79697 & -82.52294 & $4 \mathrm{~N}$ & $16 \mathrm{E}$ & 11 & 617 & 2517 & $\mathrm{D}$ & 2 \\
\hline 23797 & St. Clair & & & & & 42.77442 & -82.54225 & $4 \mathrm{~N}$ & $16 \mathrm{E}$ & 15 & 622 & 2522 & $\mathrm{D}$ & 2 \\
\hline 23821 & St. Clair & & & & & 42.79708 & -82.53279 & $4 \mathrm{~N}$ & $16 \mathrm{E}$ & 11 & 621 & 2521 & $\mathrm{D}$ & 2 \\
\hline 23840 & St. Clair & & & & & 42.78675 & -82.50251 & $4 \mathrm{~N}$ & $16 \mathrm{E}$ & 13 & 599 & 2630 & $\mathrm{D}$ & 2 \\
\hline 23866 & St. Clair & & 758 & 880 & & 42.77860 & -82.52238 & $4 \mathrm{~N}$ & $16 \mathrm{E}$ & 14 & 601 & 2549 & $\mathrm{D}$ & 1 \\
\hline 23908 & St. Clair & & & & & 42.79347 & -82.51801 & $4 \mathrm{~N}$ & $16 \mathrm{E}$ & 11 & 605 & 2554 & $\mathrm{D}$ & 2 \\
\hline 23934 & St. Clair & & & & & 42.80455 & -82.52378 & $4 \mathrm{~N}$ & $16 \mathrm{E}$ & 2 & 617 & 2637 & $\mathrm{D}$ & 2 \\
\hline 24026 & St. Clair & & & & & 42.78609 & -82.52238 & $4 \mathrm{~N}$ & $16 \mathrm{E}$ & 14 & 603 & 2492 & $D$ & 2 \\
\hline 24051 & St. Clair & & & & & 42.79006 & -82.50825 & $4 \mathrm{~N}$ & $16 \mathrm{E}$ & 12 & 602 & 2571 & $\mathrm{O}$ & 2 \\
\hline 24313 & St. Clair & & & & & 42.78657 & -82.50743 & $4 \mathrm{~N}$ & $16 \mathrm{E}$ & 13 & 602 & 0 & $\mathrm{D}$ & 1 \\
\hline 24360 & St. Clair & & & & & 42.76668 & -82.54154 & $4 \mathrm{~N}$ & $16 \mathrm{E}$ & 22 & 625 & 2585 & $\mathrm{D}$ & 1 \\
\hline 24372 & St. Clair & & & & & 42.79708 & -82.51818 & $4 \mathrm{~N}$ & $16 \mathrm{E}$ & 11 & 606 & 2540 & $\mathrm{D}$ & 1 \\
\hline 24393 & St. Clair & & & & & 42.79526 & -82.53044 & $4 \mathrm{~N}$ & $16 \mathrm{E}$ & 11 & 620 & 2535 & $\mathrm{D}$ & 1 \\
\hline 24468 & St. Clair & & & & & 42.76436 & -82.50057 & $4 \mathrm{~N}$ & $16 \mathrm{E}$ & 24 & 588 & 2446 & $\mathrm{D}$ & 1 \\
\hline 24534 & St. Clair & & & & & 42.78623 & -82.51779 & $4 \mathrm{~N}$ & $16 \mathrm{E}$ & 14 & 597 & 0 & $\mathrm{D}$ & 1 \\
\hline 24796 & St. Clair & & & & & 42.76372 & -82.52168 & $4 \mathrm{~N}$ & $16 \mathrm{E}$ & 23 & 601 & 2593 & $\mathrm{D}$ & 1 \\
\hline 24894 & St. Clair & & & & & 42.78036 & -82.53842 & $4 \mathrm{~N}$ & $16 \mathrm{E}$ & 15 & 622 & 0 & $\mathrm{D}$ & 1 \\
\hline 24895 & St. Clair & & & & & 42.78379 & -82.53498 & $4 \mathrm{~N}$ & $16 \mathrm{E}$ & 15 & 620 & 2521 & $\mathrm{D}$ & 1 \\
\hline 24896 & St. Clair & & & & & 42.79161 & -82.53027 & $4 \mathrm{~N}$ & $16 \mathrm{E}$ & 11 & 619 & 2705 & $\mathrm{D}$ & 1 \\
\hline 24897 & St. Clair & & & & & 42.77640 & -82.53971 & $4 N$ & $16 \mathrm{E}$ & 15 & 618 & 2539 & $\mathrm{D}$ & 1 \\
\hline 24967 & St. Clair & & & & & 42.78985 & -82.51797 & $4 \mathrm{~N}$ & $16 \mathrm{E}$ & 11 & 603 & 2671 & $D$ & 1 \\
\hline 25022 & St. Clair & & & & & 42.78797 & -82.53027 & $4 \mathrm{~N}$ & $16 \mathrm{E}$ & 11 & 618 & 2517 & $\mathrm{D}$ & 2 \\
\hline 25133 & St. Clair & & & & & 42.79888 & -82.53059 & $4 \mathrm{~N}$ & $16 \mathrm{E}$ & 11 & 622 & 2709 & $\mathrm{D}$ & 5 \\
\hline 25134 & St. Clair & & & & & 42.77980 & -82.54470 & $4 \mathrm{~N}$ & $16 \mathrm{E}$ & 15 & 623 & 2685 & $D$ & 1 \\
\hline 25216 & St. Clair & & & & & 42.80266 & -82.52625 & $4 \mathrm{~N}$ & $16 \mathrm{E}$ & 2 & 618 & 2722 & $\mathrm{D}$ & 1 \\
\hline 25217 & St. Clair & & & & & 42.77606 & -82.54470 & $4 \mathrm{~N}$ & $16 \mathrm{E}$ & 15 & 622 & 2690 & $\mathrm{D}$ & 1 \\
\hline 25230 & St. Clair & & & & & 42.80057 & -82.51840 & $4 \mathrm{~N}$ & $16 \mathrm{E}$ & 11 & 607 & 2693 & $D$ & 1 \\
\hline 25269 & St. Clair & & & & & 42.79901 & -82.52555 & $4 \mathrm{~N}$ & $16 \mathrm{E}$ & 11 & 620 & 2540 & $G$ & 1 \\
\hline 25285 & St. Clair & & & & & 42.80097 & -82.52309 & $4 N$ & $16 \mathrm{E}$ & 11 & 621 & 2540 & $D$ & 1 \\
\hline
\end{tabular}


M. Le, MS Thesis, 2004

\begin{tabular}{|c|c|c|c|c|c|c|c|c|c|c|c|c|c|c|}
\hline Permit & Name & RGRC & DNDE & DRRV & DRB & Latitude & Longitude & Twn & Rng & Sec & $\mathrm{KB}$ & TD & Type & Omit \\
\hline 25644 & St. Clair & & & & & 42.79903 & -82.52248 & $4 N$ & $16 \mathrm{E}$ & 11 & 618 & 2585 & $D$ & 1 \\
\hline 25739 & St. Clair & & & & & 42.80065 & -82.52806 & $4 \mathrm{~N}$ & $16 \mathrm{E}$ & 11 & 621 & 2700 & $\mathrm{D}$ & 6 \\
\hline 25779 & St. Clair & & & & & 42.78588 & -82.52866 & $4 \mathrm{~N}$ & $16 \mathrm{E}$ & 14 & 614 & 2577 & $\mathrm{D}$ & 1 \\
\hline 25780 & St. Clair & & 535 & 654 & & 42.59884 & -82.56890 & $2 \mathrm{~N}$ & $16 \mathrm{E}$ & 0 & 579 & 4186 & $\mathrm{D}$ & 1 \\
\hline 25894 & St. Clair & & & & & 42.81531 & -82.53894 & $4 \mathrm{~N}$ & $16 \mathrm{E}$ & 3 & 613 & 2694 & $\mathrm{D}$ & 1 \\
\hline 26066 & St. Clair & & & & & 42.76850 & -82.54924 & $4 \mathrm{~N}$ & $16 \mathrm{E}$ & 22 & 626 & 2600 & $D$ & 1 \\
\hline 26117 & St. Clair & & & & & 42.79183 & -82.52751 & $4 \mathrm{~N}$ & $16 \mathrm{E}$ & 11 & 616 & 0 & $\mathrm{D}$ & 1 \\
\hline 26142 & St. Clair & & & & & 42.79040 & -82.52477 & $4 \mathrm{~N}$ & $16 \mathrm{E}$ & 11 & 604 & 2528 & $\mathrm{D}$ & 1 \\
\hline 26153 & St. Clair & & & & & 42.79541 & -82.52606 & $4 \mathrm{~N}$ & $16 \mathrm{E}$ & 11 & 619 & 2549 & $\mathrm{D}$ & 1 \\
\hline 26154 & St. Clair & & & & & 42.79526 & -82.52309 & $4 \mathrm{~N}$ & $16 \mathrm{E}$ & 11 & 609 & 2537 & $\mathrm{D}$ & 3 \\
\hline 26173 & St. Clair & & & & & 42.79199 & -82.52381 & $4 \mathrm{~N}$ & $16 \mathrm{E}$ & 11 & 603 & 2542 & $\mathrm{D}$ & 1 \\
\hline 26206 & St. Clair & & & & & 42.77857 & -82.53886 & $4 N$ & $16 \mathrm{E}$ & 15 & 618 & 2566 & $D$ & 1 \\
\hline 27008 & St. Clair & & & & & 42.76026 & -82.51398 & $4 \mathrm{~N}$ & $16 \mathrm{E}$ & 23 & 601 & 2481 & $\mathrm{D}$ & 1 \\
\hline 27266 & St. Clair & & & & & 42.78395 & -82.53265 & $4 \mathrm{~N}$ & $16 \mathrm{E}$ & 14 & 619 & 2550 & $D$ & 1 \\
\hline 27267 & St. Clair & & & & & 42.78185 & -82.53472 & $4 \mathrm{~N}$ & $16 \mathrm{E}$ & 15 & 620 & 2550 & $D$ & 1 \\
\hline 27268 & St. Clair & & & & & 42.78007 & -82.53686 & $4 \mathrm{~N}$ & $16 \mathrm{E}$ & 15 & 614 & 2545 & $\mathrm{D}$ & 1 \\
\hline 27613 & St. Clair & & & & & 42.79084 & -82.52856 & $4 \mathrm{~N}$ & $16 \mathrm{E}$ & 11 & 622 & 2550 & $\mathrm{D}$ & 1 \\
\hline 27614 & St. Clair & & & & & 42.78549 & -82.53018 & $4 \mathrm{~N}$ & $16 \mathrm{E}$ & 14 & 617 & 2554 & $\mathrm{D}$ & 1 \\
\hline 27787 & St. Clair & & & & & 42.81601 & -82.51907 & $4 \mathrm{~N}$ & $16 \mathrm{E}$ & 2 & 623 & 2655 & $\mathrm{D}$ & 1 \\
\hline 27957 & St. Clair & & & & & 42.76953 & -82.52908 & $4 \mathrm{~N}$ & $16 \mathrm{E}$ & 23 & 610 & 2539 & $\mathrm{D}$ & 1 \\
\hline 28091 & St. Clair & & & & & 42.76255 & -82.53398 & $4 \mathrm{~N}$ & $16 \mathrm{E}$ & 22 & 612 & 2540 & $D$ & 1 \\
\hline 28278 & St. Clair & & & & & 42.75859 & -82.50714 & $4 \mathrm{~N}$ & $16 \mathrm{E}$ & 24 & 591 & 2448 & $\mathrm{D}$ & 1 \\
\hline 30376 & St. Clair & & 727 & 823 & & 42.69367 & -82.63069 & $3 N$ & $15 \mathrm{E}$ & 14 & 603 & 4550 & $\mathrm{D}$ & 1 \\
\hline 32711 & St. Clair & & & & & 42.77796 & -82.49737 & $4 \mathrm{~N}$ & $16 \mathrm{E}$ & 13 & 598 & 2487 & $\mathrm{G}$ & 2 \\
\hline 32726 & St. Clair & & & & & 42.78657 & -82.50742 & $4 \mathrm{~N}$ & $16 \mathrm{E}$ & 13 & 602 & 2601 & Obs & 2 \\
\hline 32915 & St. Clair & & & & & 42.76359 & -82.51640 & $4 \mathrm{~N}$ & $16 \mathrm{E}$ & 23 & 605 & 2610 & $\mathrm{D}$ & 2 \\
\hline 38964 & St. Clair & & 1531 & 1695 & & 42.90919 & -82.97129 & $6 \mathrm{~N}$ & $13 \mathrm{E}$ & 30 & 801 & 6696 & $\mathrm{D}$ & 3 \\
\hline 38965 & St. Clair & & 1484 & 1639 & & 42.99864 & -82.80874 & $7 \mathrm{~N}$ & $14 \mathrm{E}$ & 34 & 804 & 6310 & $\mathrm{D}$ & 1 \\
\hline 39602 & St. Clair & & 1671 & 1847 & 1880 & 43.12860 & -82.75756 & $8 \mathrm{~N}$ & $15 \mathrm{E}$ & 18 & 791 & 6751 & $\mathrm{D}$ & 1 \\
\hline 40698 & St. Clair & & 1558 & 1720 & 1752 & 43.13029 & -82.70612 & $8 \mathrm{~N}$ & $15 E$ & 16 & 769 & 6500 & $\mathrm{D}$ & 1 \\
\hline 31335 & St. Joseph & & 1159 & 1247 & & 41.95671 & -85.43117 & $6 S$ & $10 \mathrm{~W}$ & 11 & 892 & 5283 & $\mathrm{D}$ & 2 \\
\hline 31708 & St. Joseph & & 1043 & 1129 & & 41.93576 & -85.54834 & $6 S$ & $11 \mathrm{~W}$ & 23 & 844 & 3065 & $\mathrm{D}$ & 1 \\
\hline
\end{tabular}


M. Le, MS Thesis, 2004

\begin{tabular}{|c|c|c|c|c|c|c|c|c|c|c|c|c|c|c|}
\hline Permit & Name & RGRC & DNDE & DRRV & DRB & Latitude & Longitude & Twn & Rng & Sec & $\mathrm{KB}$ & TD & Type & Omit \\
\hline 23890 & Tuscola & & & & & 43.56652 & -83.43100 & $13 N$ & $9 \mathrm{E}$ & 8 & 678 & 10130 & D & 2 \\
\hline 25609 & Tuscola & 2595 & 2645 & 2994 & 2973 & 43.54415 & -83.18904 & $13 \mathrm{~N}$ & $11 \mathrm{E}$ & 16 & 738 & 9296 & $\mathrm{D}$ & 1 \\
\hline 35456 & Tuscola & 2610 & 2625 & 2886 & 2911 & 43.33251 & -83.52020 & $11 \mathrm{~N}$ & $8 \mathrm{E}$ & 27 & 709 & 3590 & $\mathrm{D}$ & 1 \\
\hline 40136 & Tuscola & 2607 & 2657 & 3027 & 3061 & 43.58277 & -83.56999 & $14 N$ & $8 E$ & 30 & 626 & 11230 & $\mathrm{G}$ & 1 \\
\hline 40856 & Tuscola & 2845 & 2895 & 3255 & 3259 & 43.55610 & -83.40060 & $13 \mathrm{~N}$ & $9 \mathrm{E}$ & 10 & 717 & 10756 & $\mathrm{O}$ & 1 \\
\hline 27501 & Van Buren & & & & & 42.08930 & -86.21775 & $4 S$ & $16 W$ & 30 & 812 & 2770 & $\mathrm{D}$ & 1 \\
\hline 28590 & Van Buren & & 1455 & 1538 & 1585 & 42.38922 & -85.94393 & $1 \mathrm{~S}$ & $14 W$ & 16 & 764 & 3422 & $\mathrm{D}$ & 1 \\
\hline 31018 & Van Buren & & 1268 & 1331 & 1387 & 42.26054 & -85.92611 & $2 S$ & $14 W$ & 27 & 711 & 3265 & $\mathrm{D}$ & 1 \\
\hline 38517 & Van Buren & & 1334 & 1381 & 1484 & 42.13889 & -85.84557 & $4 S$ & $13 \mathrm{~W}$ & 8 & 967 & 3372 & $\mathrm{D}$ & 1 \\
\hline 24161 & Washtenaw & & 1541 & 1614 & & 42.37596 & -84.07237 & $1 \mathrm{~S}$ & $3 E$ & 22 & 960 & 5159 & $\mathrm{D}$ & 1 \\
\hline 24396 & Washtenaw & & 1272 & 1404 & 1402 & 42.27547 & -84.02309 & $2 S$ & $3 E$ & 25 & 939 & 4758 & $\mathrm{D}$ & 1 \\
\hline 26856 & Washtenaw & & 637 & 763 & & 42.12545 & -83.85543 & $4 S$ & $5 E$ & 17 & 862 & 3934 & $\mathrm{D}$ & 1 \\
\hline 34223 & Washtenaw & & 1242 & 1350 & & 42.35971 & -83.73385 & $1 S$ & $6 \mathrm{E}$ & 28 & 942 & 6300 & $\mathrm{D}$ & 1 \\
\hline 25560 & Wayne & & 113 & 195 & & 42.30641 & -83.17566 & $2 S$ & $11 \mathrm{E}$ & 19 & & 3752 & $\mathrm{BD}$ & 1 \\
\hline 00146BD & Wayne & & & & & 42.12997 & -83.22808 & $4 S$ & $10 \mathrm{E}$ & 22 & 588 & 3920 & $\mathrm{D}$ & 1 \\
\hline 29037 & Wexford & 2579 & 2604 & 2768 & 2968 & 44.34344 & -85.80295 & $23 N$ & $12 W$ & 31 & 911 & 6519 & $\mathrm{D}$ & 1 \\
\hline 30342 & Wexford & & & & & 44.43009 & -85.81716 & $24 N$ & $12 \mathrm{~W}$ & 31 & 1091 & 6202 & $\mathrm{D}$ & 1 \\
\hline 30903 & Wexford & & & & & 44.49885 & -85.79924 & $24 N$ & $12 \mathrm{~W}$ & 6 & 1056 & 6130 & $\mathrm{O}$ & 1 \\
\hline 31016 & Wexford & 2484 & 2519 & 2643 & & 44.50402 & -85.81591 & $24 N$ & $12 W$ & 6 & 1061 & 6145 & $\mathrm{O}$ & 1 \\
\hline 31016 & Wexford & & & & & 44.50402 & -85.81591 & $24 \mathrm{~N}$ & $12 \mathrm{~W}$ & 6 & 1061 & 6145 & $\mathrm{O}$ & 1 \\
\hline 31803 & Wexford & & & & & 44.48107 & -85.79559 & $24 \mathrm{~N}$ & $12 \mathrm{~W}$ & 17 & 1060 & 6410 & $\mathrm{G}$ & 1 \\
\hline 34612 & Wexford & 3942 & 3972 & 4185 & 4412 & 44.21061 & -85.37390 & $21 \mathrm{~N}$ & $9 W$ & 14 & 1412 & 10430 & $\mathrm{D}$ & 1 \\
\hline 35099 & Wexford & 2985 & 3030 & 3202 & & 44.46946 & -85.45745 & $24 N$ & $9 \mathrm{~W}$ & 18 & 1022 & 10100 & $\mathrm{BD}$ & 1 \\
\hline 35099 & Wexford & & & & & 44.46946 & -85.45745 & $24 N$ & $9 W$ & 18 & 1022 & 10100 & $\mathrm{BD}$ & \\
\hline 40210 & Wexford & 3043 & 3058 & 3272 & 3426 & 44.18603 & -85.74747 & $21 \mathrm{~N}$ & $12 W$ & 27 & 964 & 9635 & $\mathrm{D}$ & 1 \\
\hline
\end{tabular}




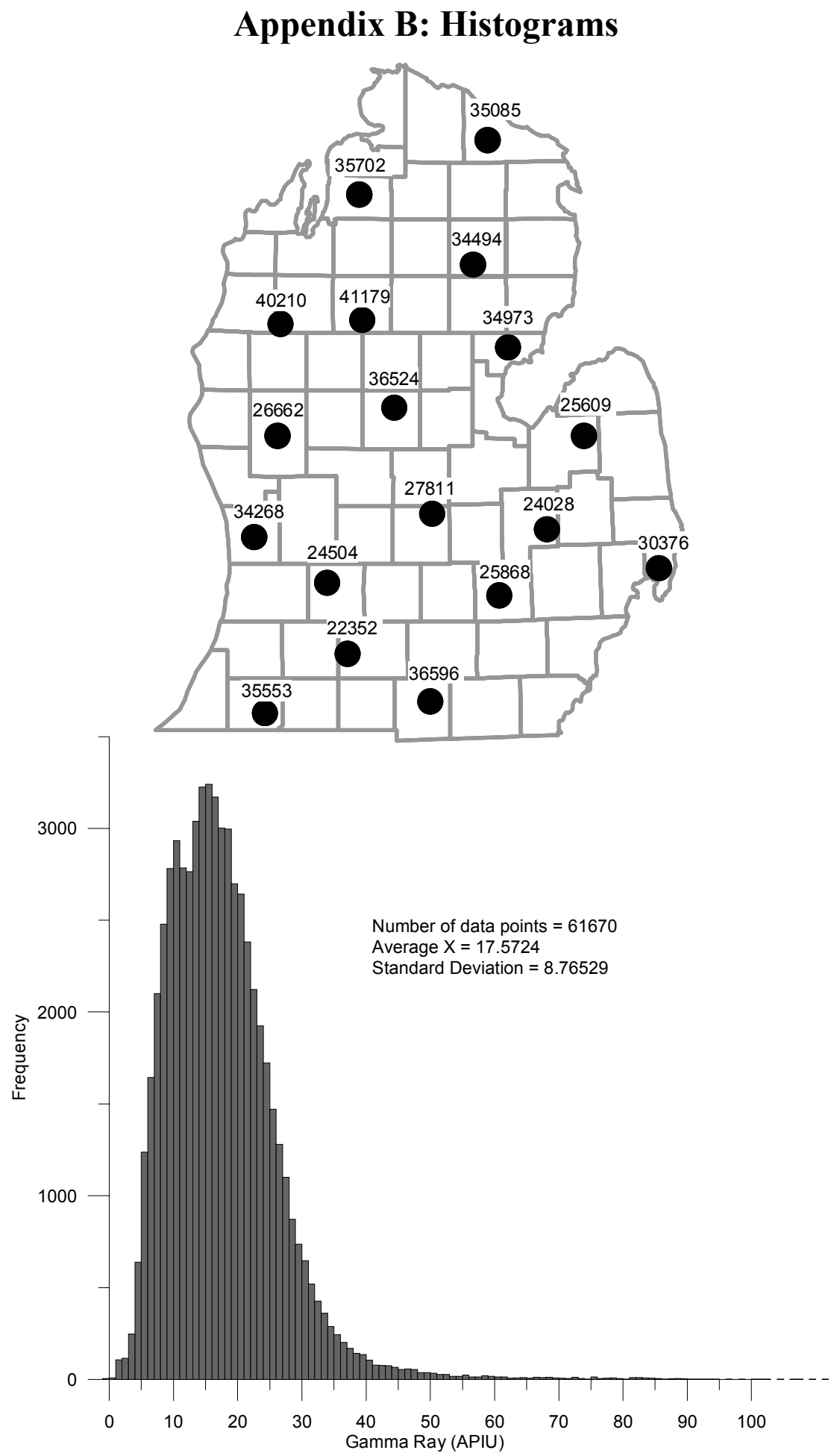

Locations and permit numbers for 18 wells distributed throughout the study area are identified above. Histograms for each of the 18 wells are shown on the following pages and the composite histogram for all 302 wells is shown directly above. The individual histogram plots illustrate gamma ray values for the Dundee-Rogers City interval (x-axis) versus the frequency of each gamma ray value (y-axis). The thickness of the Dundee-Rogers City unit varies throughout the basin and consequently, the maximum histogram frequency is not uniform. In contrast, the gamma ray range (x-axis) is 0-40 APIU for every histogram to allow for comparison. 

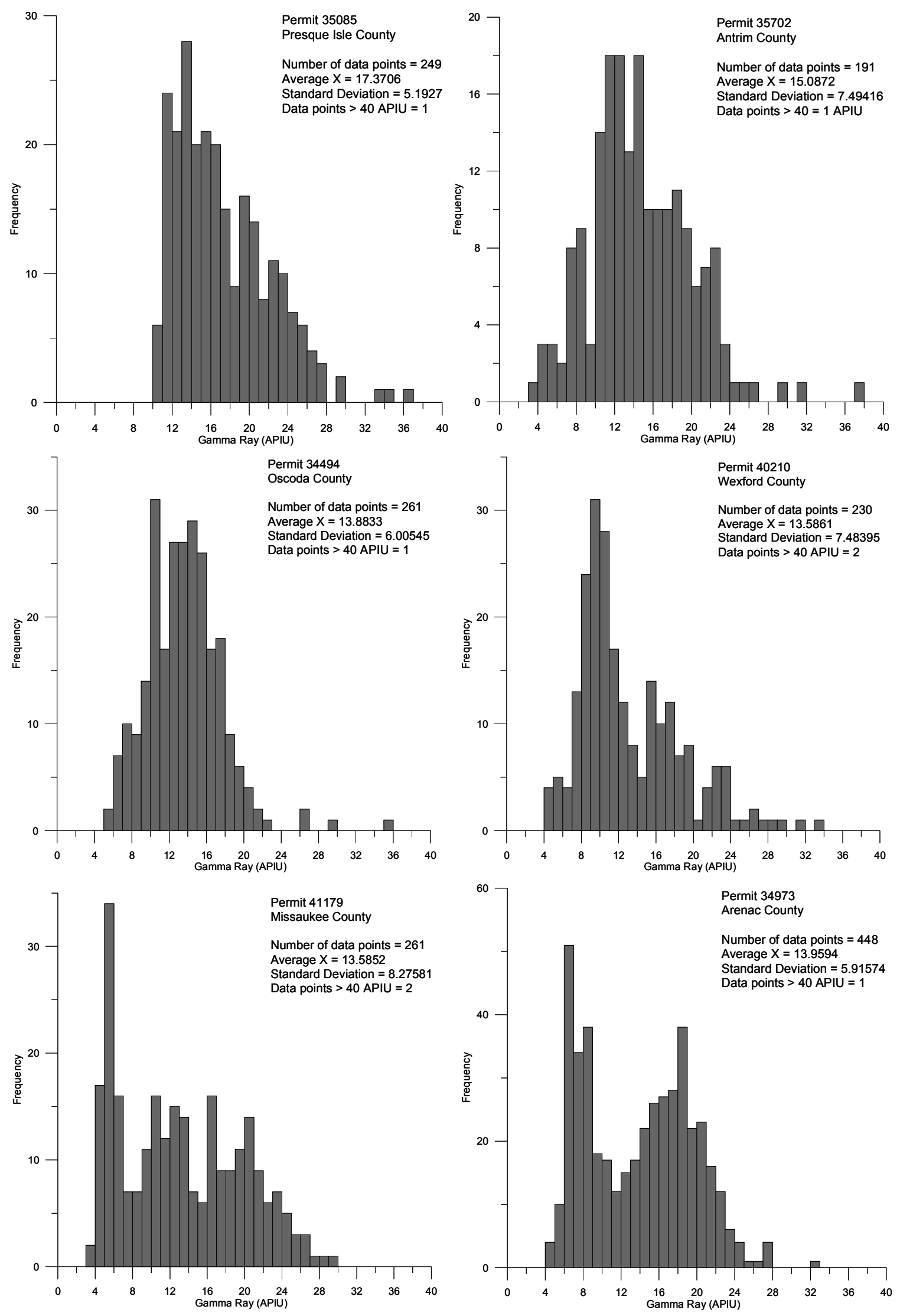

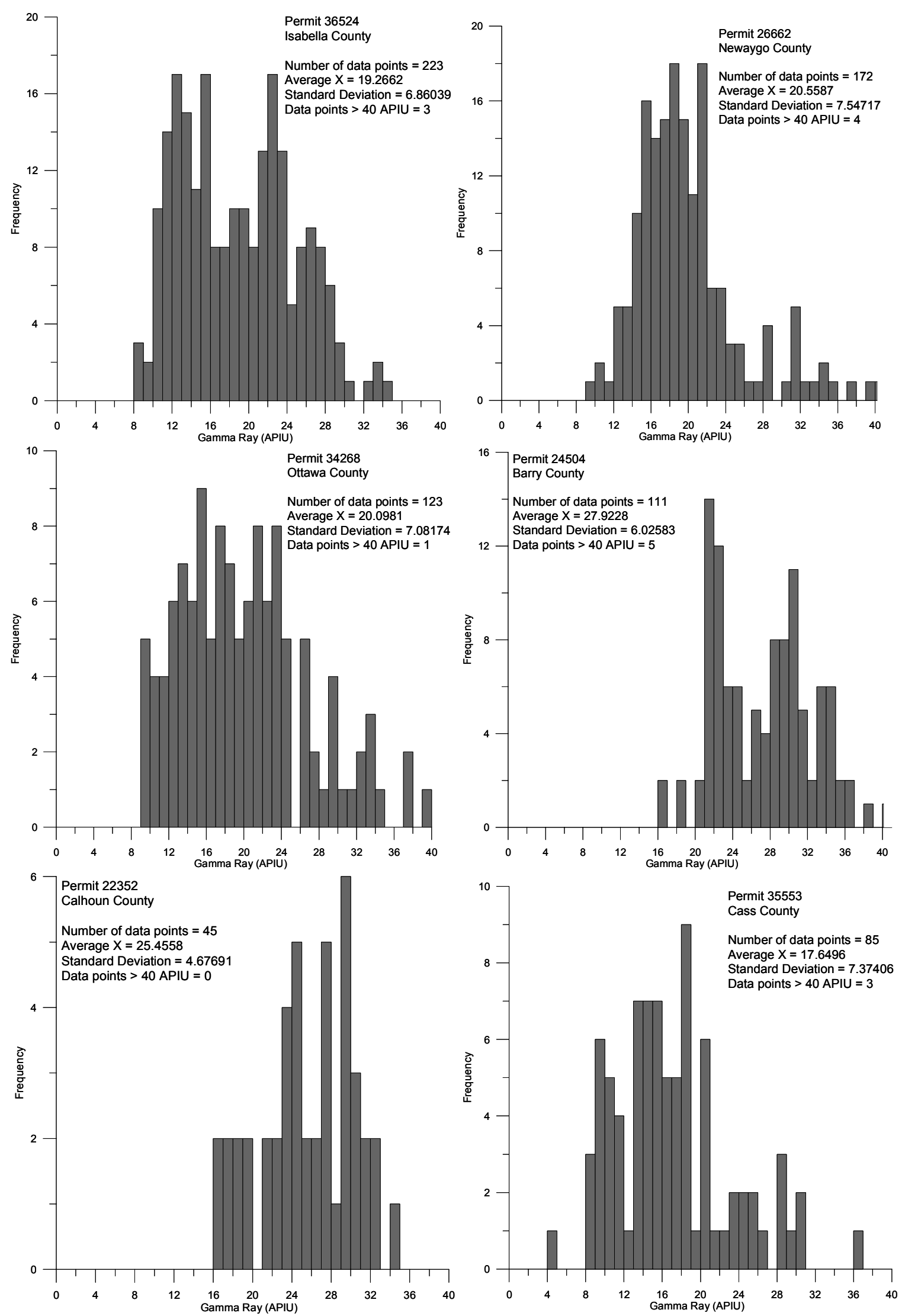

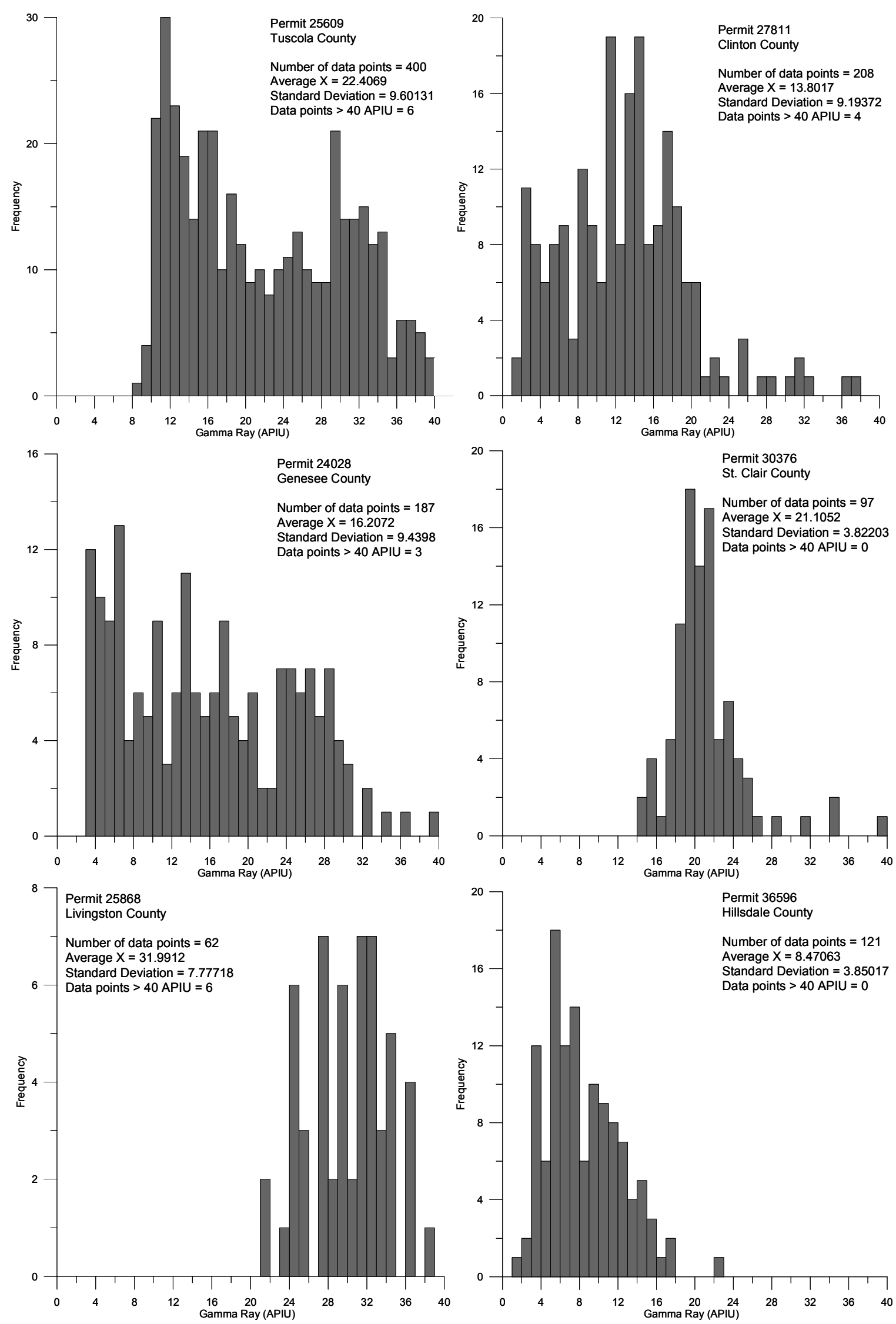


\section{Appendix C: Surfer Gridding Report}

\section{Nearest Neighbor Statistics}

$\begin{array}{lll} & \text { Separation } & \text { Delta Z } \\ \text { Minimum: } & 0.00759393 & 0.09040000 \\ \text { 25\%-tile: } & 0.05350652 & 4.322 \\ \text { Median: } & 0.09387544 & 12.59449 \\ \text { 75\%-tile: } & 0.14844219 & 24.3466 \\ \text { Maximum: } & 0.37164484 & 66.71 \\ & & \\ \text { Midrange: } & 0.18961938 & 33.4002 \\ \text { Range: } & 0.36405091 & 66.6196 \\ \text { Interquartile Range: } & 0.09493566 & 20.0246 \\ \text { Median Abs. Deviation: } & 0.04316621 & 9.25019 \\ & & \\ \text { Mean: } & 0.10653948 & 16.83974195 \\ \text { Trim Mean (10\%): } & 0.10214495 & 15.45625125 \\ \text { Standard Deviation: } & 0.06658871 & 15.19119000 \\ \text { Variance: } & 0.00443406 & 230.77225363 \\ & & \\ \text { Coef. of Variation: } & 0.62501439 & 0.90210349 \\ \text { Coef. of Skewness: } & 0.95823779 & 1.19231368 \\ & & \\ \text { Root mean Square: } & 0.12563724 & 22.67926724 \\ \text { Mean Square: } & 0.01578472 & 514.34916270\end{array}$

\section{Complete Spatial Randomness}

Lambda: $\quad 21.00911591$

Clark and Evans: $\quad 0.97666238$

Skellam: $\quad 629.26182803$

\section{Gridding Rules}

Anisotropy Ratio: 1

Anisotropy Angle: 0 


\section{Output Grid}

Grid Size: $\quad 186$ rows x 200 columns

Total nodes: $\quad 37200$

\section{Grid Geometry}

[longitude]

X Minimum: $\quad-86.44577$

X Maximum: $\quad-82.52238$

X Spacing: $\quad 0.01971553$ (degrees)

[latitude]

Y Minimum: $\quad 41.74535$

Y Maximum: $\quad 45.4092$

Y Spacing: $\quad 0.01980460$

\section{Grid Statistics}

$\begin{array}{ll}\text { Z Minimum: } & 4.60206001 \\ \text { Z 25\%-tile: } & 40.67084440 \\ \text { Z Median: } & 52.47149827 \\ \text { Z 75\%-tile: } & 61.89949068 \\ \text { Z Maximum: } & 105.12414807 \\ & \\ \text { Z Midrange: } & 54.86310406 \\ \text { Z Range: } & 100.52208802 \\ \text { Z Interquartile Range: } & 21.22864628 \\ \text { Z Median Abs. Deviation: } & 10.40104608 \\ & \\ \text { Z Mean: } & 51.08730226 \\ \text { Z Trim Mean (10\%): } & 51.14665166 \\ \text { Z Standard Deviation: } & 15.26765019 \\ \text { Z Variance: } & 233.10114222 \\ & \\ \text { Z Coef. of Variation: } & 0.29885411 \\ \text { Z Coef. of Skewness: } & -0.13272763 \\ & \\ \text { Z Root mean Square: } & 53.31991743 \\ \text { Z Mean Square: } & 2843.01359470\end{array}$




\section{Appendix D: Surfer Color Files}

Correlative Traverse Group study color scale

Used for 0-150 APIU range. Contour interval: 15 APIU.

$\begin{array}{rrrrr}\text { ColorMap } 1 & 1 & & \\ 0.000000 & 0 & 51 & 153 \\ 10.073892 & 102 & 102 & 204 \\ 19.211823 & 0 & 0 & 255 \\ 30.000000 & 0 & 204 & 255 \\ 40.000000 & 153 & 255 & 255 \\ 50.246305 & 51 & 204 & 153 \\ 60.000000 & 153 & 255 & 153 \\ 70.443350 & 255 & 255 & 0 \\ 80.295566 & 255 & 102 & 51 \\ 90.640394 & 255 & 0 & 0 \\ 100.000000 & 0 & 0 & 0\end{array}$

Blue (low Traverse Group study) color scale

Used for 0-30 APIU range. Contour interval: 3 APIU.

$\begin{array}{rrrr}\text { ColorMap } 1 & 1 & & \\ 0.000000 & 51 & 0 & 102 \\ 10.000000 & 0 & 0 & 126 \\ 20.000000 & 0 & 51 & 186 \\ 30.000000 & 0 & 137 & 205 \\ 40.000000 & 0 & 191 & 255 \\ 50.000000 & 113 & 230 & 255 \\ 60.000000 & 175 & 255 & 255 \\ 70.000000 & 190 & 255 & 255 \\ 80.000000 & 164 & 255 & 204 \\ 90.000000 & 139 & 208 & 157 \\ 100.000000 & 0 & 0 & 0\end{array}$

